UNIVERSIDADE DE SÃO PAULO

ESCOLA DE ENGENHARIA DE SÃO CARLOS

DEPARTAMENTO DE ENGENHARIA DE ESTRUTURAS

PATRICIA TAVARES DE SOUZA SPAVIER

Análise experimental e numérica de ligação entre pilar misto parcialmente revestido e viga metálica sem interrupção do concreto de revestimento

SÃO CARLOS

2020 



\section{Análise experimental e numérica de ligação entre pilar misto parcialmente revestido e viga metálica sem interrupção do concreto de revestimento}

\section{VERSÃO CORRIGIDA}

A versão original encontra-se na Escola de Engenharia de São Carlos

Tese apresentada ao Programa de PósGraduação em Engenharia Civil (Engenharia de Estruturas) da Escola de Engenharia de São Carlos da Universidade de São Paulo para obtenção do título de Doutor em Ciências.

Área de Concentração: Estruturas

Orientador: Prof. ${ }^{a}$ Dr. ${ }^{a}$ Ana Lucia H. C. El Debs 
AUTORIZO A REPRODUÇÃO TOTAL OU PARCIAL DESTE TRABALHO, POR QUALQUER MEIO CONVENCIONAL OU ELETRÔNICO, PARA FINS DE ESTUDO E PESQUISA, DESDE QUE CITADA A FONTE.

Ficha catalográfica elaborada pela Biblioteca Prof. Dr. Sérgio Rodrigues Fontes da EESC/USP com os dados inseridos pelo(a) autor(a).

Spavier, Patricia Tavares de Souza

Analiae experimental e numérica de ligação

entre pilar miato parcialmente revestido e viga

metalica sem interrupçäo do concreto de reveatimento /

Patricia Tavarea de Souza Spavier; orientadora Ana

Lucia Honce de Cregce Bl Deba. Säo Carlos, 2020.

T'ese (Doutorado) - Programa de P6s-Graduaçăo em Engenharia Civil (Engenharia de Eatruturas) e Área de Concentração em Eatruturas -. Escola de Engenharia de săo Carlog da univeraidade de säo paulo, 2020.

1. Estruturas miataa. 2. Ligaçăo viga-pilar. 3. Pilar parcialmente reveatido. 4. Concreto com fibras. 5. Analize experimental. 6. Analiae numerica. I. Titulo. 


\section{FOLHA DE JULGAMENTO}

Candidata: Engenheira PAIRICIA TAVARES DE SOUZA SPAVIER.

Titulo da tese: " Análise experimental e numérica de ligaçăo entre pilar misto parcialmente revestido e viga metálica sem inferrupçôo do concreto de revestimento".

Data da defesa: $30 / 07 / 2020$

Comissāo Julgadora

Profa. Associada Ana Lucla Homce de Cresce a Debs (Orlentadora)

(Escola de Engenharia de São Carlos - EESC/USP)

Prot. Tilular Maxdmilliano Mallie

(Escola de Engenharia de são Carlos - EESC/USP)

Profa. Dra. Silvana De Nardin

(Universidade Federal de São Carlos/UFSCar)

Prof. Dr. Pedro Colmar Gonçalves da Silva Vellasco

(Universidade do Estado do Rio de Janeiro/UERJ)

Prof. Dr. Carlos Eduardo Javaronl

$\triangle P R O U A D A$ $\triangle P R O N A D A$

Resultado

APROVADA

LPROUADA

APRON ADS

(Universidade Estadual Paulista "Júlio de Mesquita Filho"/UNESP - Bauru)

Coordenador do Programa de Pós-Graduação em Engenharia Civill (Engenharia de Estruturas):

Prof. Associado Vladlmir Gullherme Haach

Presidente da Comissão de Pós-Graduaçāo:

Prof. Titular Murllo Araujo Romero 

Com imensa gratidão e amor, dedico este trabalho a Deus, aos meus pais Severino e Celia e ao meu marido Bruno. 



\section{AGRADECIMENTOS}

"Não te mandei eu? Esforça-te, e tem bom ânimo; não temas, nem te espantes; porque o Senhor teu Deus é contigo, por onde quer que andares" (Josué 1:9). Em primeiro lugar, agradeço a Deus por concluir mais esta etapa em minha vida, pois o Senhor me deu infinitamente mais do que pedi ou sonhei e a Sua Mão tem me sustentado por toda a minha vida.

Agradeço aos meus pais que sempre me amaram incondicionalmente, que sempre acreditaram em mim e me incentivaram a prosseguir e progredir, pois o que eu sou hoje é fruto de cada gesto de amor, carinho, renúncia e apoio. Obrigada por todas as orações que abençoaram minha vida e todos os momentos felizes, eu lhes amo muito.

Agradeço ao meu amado marido que durante esses quatro anos, nos conhecemos, namoramos e casamos. Você tem sido o sol nos meus dias mais nublados e a simplificação das minhas equações mais complicadas. A sua fé em mim, me faz acreditar que tudo vai ficar bem. Sua parceria foi essencial, eu te amo muito e essa vitória é nossa, pois somos um em Deus.

Agradeço aos meus familiares e amigos pelo carinho, pelos conselhos, pelo apoio e pela alegria que me proporcionaram, pois, é na hora da dificuldade que conhecemos os verdadeiros irmãos. Cada um tem um lugar especial em meu coração e é muito prazeroso compartilhar mais essa vitória com vocês. Deixo o meu muito obrigado para sala D6, meninas, vocês foram muito importantes neste processo.

Agradeço à minha orientadora Ana Lúcia Homce de Cresce El Debs e aos professores do Departamento de Engenharia de Estruturas da EESC por toda a dedicação e por todo ensinamento durante estes quatro anos. Obrigada por doarem sua paciência, seu conhecimento e seus valores. Os senhores são parte integrante e fundamental de minha formação.

Agradeço a todos os funcionários que colaboraram para o sucesso deste trabalho, especialmente aos técnicos Luiz Vareda, Amaury, Mauri, Jorge e Fabiano, pois o que seria da Fórmula 1 se não fosse a competência da equipe do piloto no pit stop?

Agradeço a CNPq por financiar a minha pesquisa e me conceder esta oportunidade. 

"Porque dele e por ele, e para ele, são todas as coisas; glória, pois, a ele eternamente. Amém”. 



\section{RESUMO}

SPAVIER, P. T. S. Análise experimental e numérica de ligação entre pilar misto parcialmente revestido e viga metálica sem interrupção do concreto de revestimento. 2020. Tese (Doutorado em Ciências - Engenharia Civil (Engenharia de Estruturas)) - Escola de Engenharia de São Carlos, Universidade de São Paulo, São Carlos, 2020.

Neste trabalho, apresenta-se um estudo experimental e numérico do comportamento de ligações entre o pilar misto e a viga de aço. O objetivo foi avaliar a contribuição do concreto de revestimento com fibras na capacidade resistente e rigidez das ligações. Quanto às ligações viga-pilar, seis tipologias de ligação foram ensaiadas em caráter exploratório, sendo duas para definição da geometria e quatro compostas por chapas de topo estendida e barras passantes com a variação do eixo de inércia do pilar misto parcialmente revestido e a presença do concreto de revestimento na ligação. Para simular pilares internos submetidos ao carregamento estático, modelos cruciformes foram ensaiados. Discutem-se os resultados experimentais, sobretudo quanto à capacidade resistente, rotações das ligações, deslocamentos e deformações nos elementos. Paralelamente, um estudo numérico foi desenvolvido para ligações viga-pilar misto sem a interrupção do concreto de revestimento com o objetivo de analisar outros parâmetros, tais como, espessura da chapa de topo, diâmetro da barra passante, carregamento do pilar e resistência do aço. A simulação numérica foi realizada nos programas DIANA versão 9.6 e Midas $\mathrm{Fx}^{+}$, baseados no método dos elementos finitos, por meio de modelos tridimensionais de ligações viga-pilar. As propriedades não-lineares dos materiais aço e concreto foram incorporadas aos modelos e as interfaces entre os elementos da ligação também foram consideradas. Os resultados da modelagem numérica mostraram-se representativos com uma pequena variação da rigidez devido a não consideração da solda, tornando-se uma ferramenta para análises paramétricas. Concluiu-se que o comportamento das ligações viga-pilar misto depende do eixo de inércia do pilar parcialmente revestido e que a presença do concreto de revestimento contribui significativamente para o aumento da capacidade resistente. Além disso, a resistência do aço da viga teve maior influência na capacidade resistente do que os outros parâmetros analisados.

Palavras-chave: Estruturas mistas. Ligações viga-pilar. Pilar misto parcialmente revestido. Concreto com fibras. Análise experimental. Análise numérica. 



\begin{abstract}
SPAVIER, P. T. S. Experimental and numerical analysis of the beam-to-column connection between the partially encased concrete column and the steel beam without interruption of fiber-added concrete. 2020. Thesis ( $\mathrm{PhD}$. in Civil Engineering (Structural Engineering)) - School of Engineering of São Carlos, University of São Paulo, São Carlos, 2020 .
\end{abstract}

This work presents an experimental and numerical study on the behaviour of beam-to-column connections involving partially encased steel-concrete columns and steel beams. The main objective was to evaluate the contribution of fibre-reinforced concrete at the connections for their ultimate capacity and stiffness. In this way, six connections were tested in a short program. First two were exploratory and they were used to define the typology of the studied connection. The definitive experimental program consisted of the four remaining specimens using the adopted solution with extended end-plates and bolts. Cruciform models were used simulating internal joints. The investigated parameter was the presence of fibre-reinforced concrete at the connection, when subjected to bending moments about the highest and lowest axis of inertia. Experimental results showed the effective contribution of concrete at the connection and obtained capacities, rotations, displacements and deformations were discussed. In addition, a numerical study was carried out in order to analyse the influence of other parameters on the connection behaviour, such as thickness of the end-plate, bolt diameter, column axial load and steel strength. The numerical simulation used three-dimensional models and was performed in the Finite Element Based software DIANA version 9.6 with Midas Fx +. The nonlinear properties of steel and concrete were incorporated and the interfaces between steel and concrete were also considered. The results of the numerical modelling were consistent, with a small variation in stiffness due to the non-consideration of the welding. Therefore, a parametric analysis was performed, showing that the behaviour of the studied connection was affected by the presence of fibre-reinforced concrete and also by the direction of the bending moment. Finally, the parametric analysis showed that the strength of steel beam had the highest influence on the connection behaviour, among all tested parameters.

Keywords: Composite Structures. Beam-to-column connection. Partially encased concrete column. Fiber-added concrete. Experimental analysis. Numerical modeling. 



\section{INTRODUCÃO_..................................................................................................19}

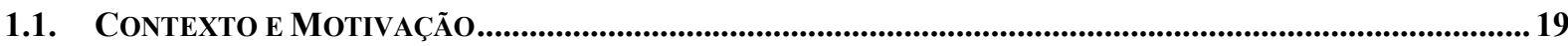

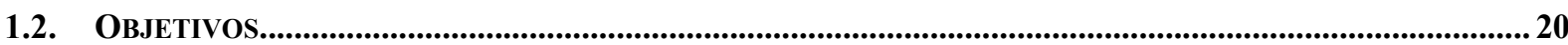

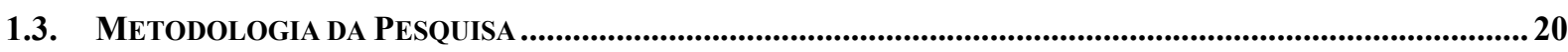

1.4. ORGANIZAÇÃO DA TESE ............................................................................................................................ 21

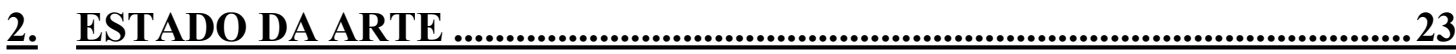

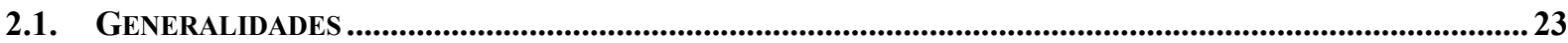

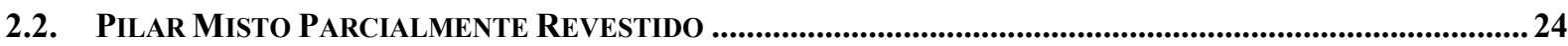

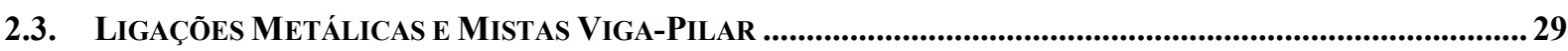

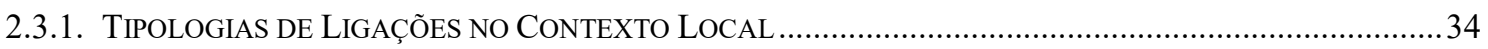

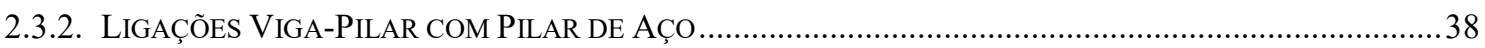

2.3.3. LigaÇões Viga-Pilar com Pilar Misto Revestido de ConCRETO ……....................................... 43

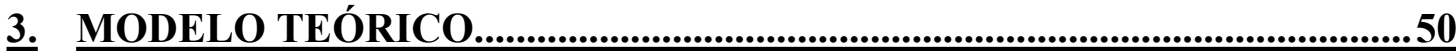

3.1. Dimensionamento de LigaÇão Viga-PILAR Segundo EC3 Parte 1-8

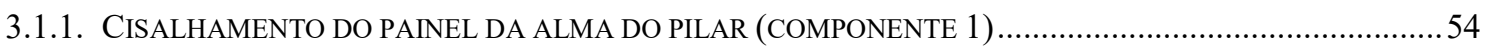

3.1.2. FLAMBAGEM DA ALMA DO PILAR POR COMPRESSÃO TRANSVERSAL (COMPONENTE 2)......................55

3.1.3. ESCOAMENTO DA ALMA DO PILAR POR TRAÇÃO TRANSVERSAL (COMPONENTE 3) ............................58

3.1.4. MESA DO PILAR EM FLEXÃO TRANSVERSAL (COMPONENTE 4) ...........................................................5

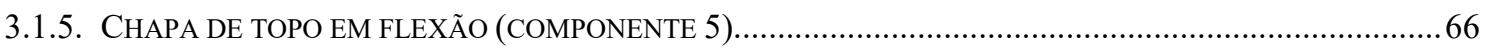

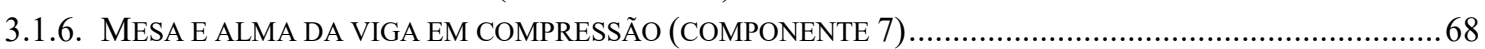

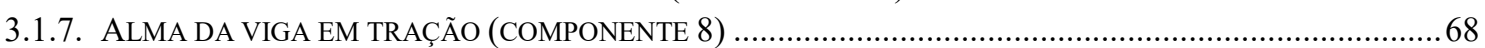

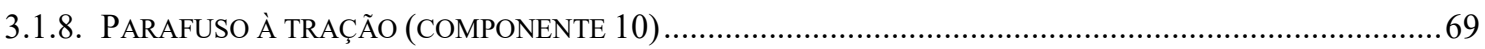

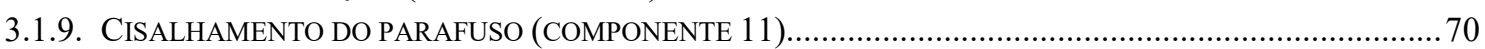

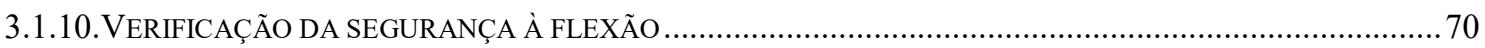

3.2. DIMENSIONAMENTO DE LIGAÇão VIGA-PILAR SEGUNDO ABNT NBR 8800 ….......................................73

\section{INVESTIGACẼ̃O EXPERIMENTAL..............................................................76}

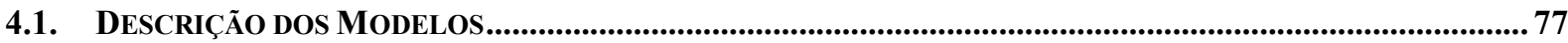

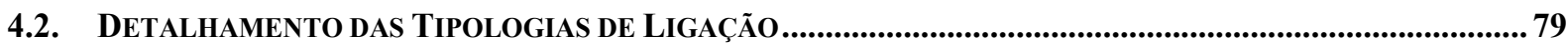

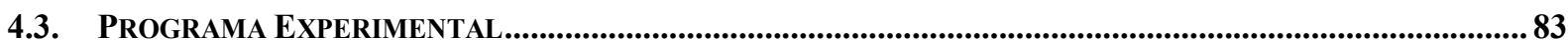

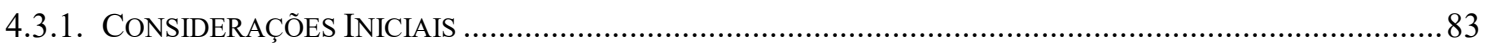

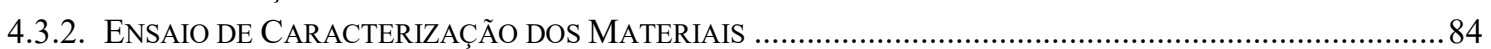

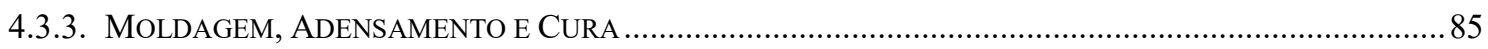

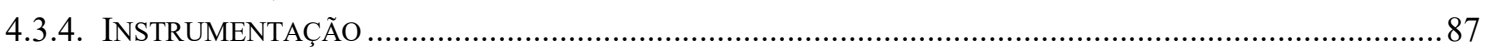

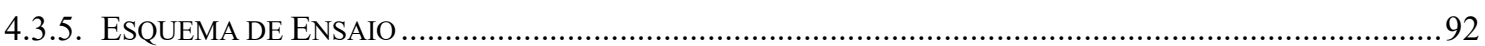

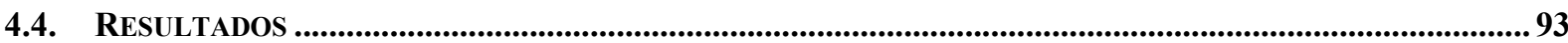

4.4.1. PRoPriedades MeCÂNICAS dos MATERIAIS QUE COMPÕEM OS MODELOS PILOTOS........................ 93 


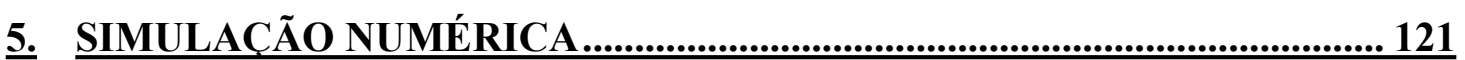

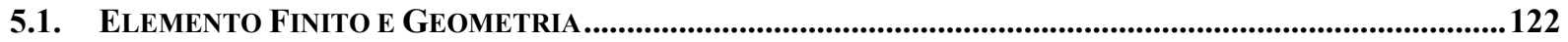

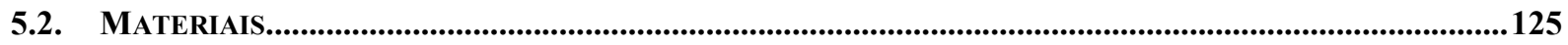

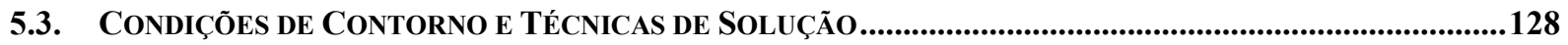

5.4. VALIDAÇÃO dOS MOdELOS DEFINITIVOS SEM INTERRUPÇÃO dO CONCRETO .......................................128

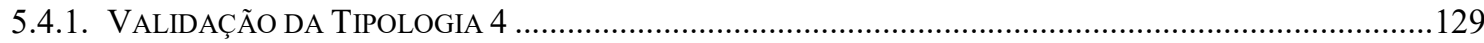

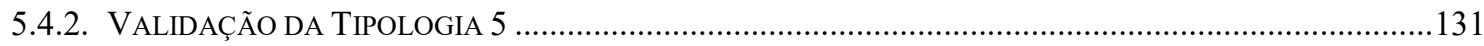

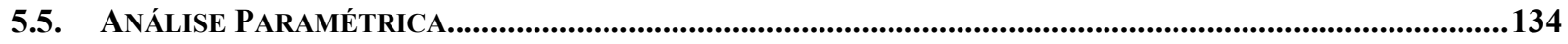

5.5.1. ANÁLISE PARAMÉTRICA DA TIPOLOGIA 4 ................................................................................ 134

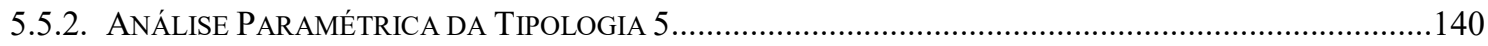

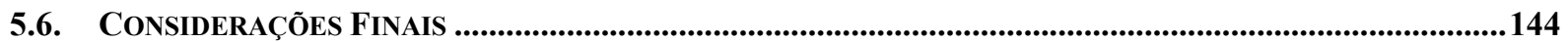

6. CONCLUSÕES $\ldots \ldots \ldots \ldots \ldots \ldots \ldots \ldots \ldots \ldots \ldots \ldots \ldots \ldots \ldots \ldots \ldots \ldots \ldots \ldots \ldots \ldots \ldots \ldots \ldots \ldots \ldots \ldots \ldots \ldots \ldots \ldots \ldots \ldots 145$

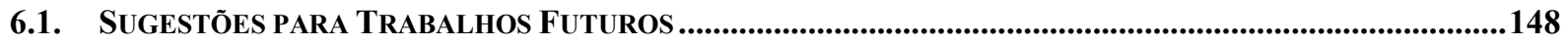

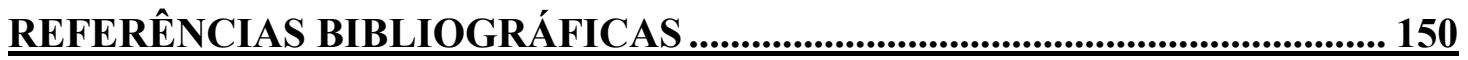

ANEXO A................................................................................ 154 


\section{INTRODUÇÃO}

\subsection{Contexto e Motivação}

A otimização dos sistemas estruturais e construtivos busca a racionalização do consumo de materiais e mão de obra aliada com a eficiência e segurança estrutural. $\mathrm{Na}$ associação de perfis de aço e concreto estrutural, formando uma seção resistente mista, são combinadas as vantagens de cada um dos materiais, de modo que se obtenha o máximo desempenho destes. Logo, os sistemas estruturais mistos são uma opção para o aprimoramento dos sistemas estruturais e construtivos. Podem-se destacar algumas vantagens dessa solução, como a redução das dimensões da seção transversal, economia de materiais e mão de obra; resistência ao fogo, maior capacidade resistente, rigidez e ductilidade. Além disso, as vantagens podem se estender ao processo construtivo, já que os elementos mistos são compatíveis com um processo de préfabricação, uma vez que as partes ou o todo podem ser fabricados fora da obra.

Entretanto, notam-se alguns obstáculos para o uso de elementos mistos, por exemplo:

- Pouco conhecimento de projeto destes elementos pelos engenheiros civis, uma vez que somente em 2008 os elementos mistos tiveram recomendações normativas com a ABNT NBR 8800 (Norma Brasileira, 2008) e parte das grades curriculares de engenharia civil não abrangem esse assunto;

- Dificuldades com a ligação destes elementos com os demais elementos que compõem a estrutura;

- Falta de pesquisas sobre ligações no eixo de menor momento de inércia do pilar misto.

As ligações têm grande importância na concepção do modelo estrutural, já que as hipóteses adotadas no projeto devem ser adequadas ao comportamento real da ligação. Somando-se a isso, as ligações afetam aspectos econômicos e construtivos devendo ser projetadas para que a estrutura apresente desempenho, durabilidade e economia. Neste contexto, observa-se que os detalhes de ligações disponíveis na literatura são complexos, resultando em dificuldades na execução, e que as pesquisas sobre elementos mistos são escassas e muitas vezes não representam a realidade brasileira, pois não abrangem geometrias e dimensões necessárias para aplicações práticas. Desta forma, o estudo das ligações é fundamental para promover a compreensão do comportamento global dos sistemas mistos, bem 
como, para inclusão destes no panorama nacional, de modo a estimular a industrialização da construção civil brasileira.

\subsection{Objetivos}

O objetivo geral desta pesquisa foi investigar alternativas para conectar vigas de aço a pilares mistos parcialmente revestidos sem a interrupção do concreto na região da ligação, e assim, foi realizado o estudo da ligação com chapa de topo e barras passantes entre o pilar misto parcialmente revestido por concreto com fibras e as vigas de aço. Alguns objetivos específicos podem ser listados:

I - Investigar o comportamento estrutural das ligações viga-pilar misto com chapa de topo e barras passantes nos eixos de maior e menor momento de inércia do pilar, com e sem a interrupção do concreto;

II - Estudar o mecanismo de transferência de forças entre os elementos da ligação;

III - Desenvolver um modelo numérico em elementos finitos das ligações propostas para análise da influência de outros parâmetros, tais como, resistência do aço, dimensões das barras passantes e chapas de topo, carregamento do pilar e outros;

IV - Avaliar a não interrupção do concreto na região da ligação com a substituição do concreto armado convencional de pilares mistos parcialmente revestidos por concreto com adição de fibras de aço, a fim de facilitar o processo construtivo no qual é complexo a execução de uma ligação com a concentração de armaduras no nó.

\subsection{Metodologia da Pesquisa}

A metodologia a seguir foi utilizada para atingir aos objetivos descritos no item anterior:

A forma de estudo da ligação viga-pilar misto consistiu de ampla revisão bibliográfica com objetivo de identificar o panorama atual das pesquisas e as características importantes a serem investigadas mais detalhadamente. Na revisão bibliográfica foi possível também reunir os detalhes de ligação já estudados e, a partir daí, elaborar uma tipologia de ligação simples e de fácil execução. Concluída essa etapa, foi elaborado o programa experimental que consistiu em seis ensaios de ligações viga-pilar, incluindo dois modelos pilotos para definir as dimensões dos elementos, tipo de ligação, esquema de ensaio e forma de aplicação da força. A definição da geometria do modelo e o esquema de carregamento foram inspirados nos estudos já 
realizados no laboratório de estruturas da EESC, limitados pela capacidade e pela disponibilidade dos equipamentos. A escolha das mesmas dimensões entre os pilares permitiu comparações relacionadas aos parâmetros: a presença do concreto com fibras na ligação vigapilar e o eixo de flexão. Os modelos físicos reproduziram ligações com pilar intermediário, gerando protótipos com formato cruciforme, os quais foram submetidos à força estática. Portanto, a investigação experimental permitiu conhecer o mecanismo de transferência de forças entre aço e concreto, compreender o comportamento da ligação viga-pilar misto e avaliar a aplicabilidade de algumas normas técnicas existentes. Para simular o comportamento das ligações observado em laboratório, foram desenvolvidos modelos numéricos representativos de ligações viga-pilar misto considerando as não linearidades físicas disponíveis no programa FX+ DIANA, com a utilização de modelagem tridimensional. Além disso, os resultados experimentais permitiram calibrar os modelos numéricos de referência e, uma vez validados, esses modelos foram utilizados em simulações numéricas adicionais para uma análise paramétrica na qual o objetivo foi extrapolar os resultados experimentais e investigar variáveis não analisadas, como: a resistência ao escoamento do aço, o carregamento do pilar e as dimensões do modelo (espessura da chapa de topo e diâmetro dos parafusos). A partir de todas as análises realizadas foi possível compreender o comportamento mecânico da ligação, indicando a sensibilidade da capacidade resistente a essas variáveis e quais desses parâmetros são de grande influência na rigidez.

\subsection{Organização da Tese}

O corpo desta tese foi organizado em seis capítulos. Neste primeiro capítulo são apresentados a introdução sobre a importância do estudo das estruturas mistas, bem como as justificavas e objetivos que motivam esta pesquisa, seguidos pela metodologia da pesquisa para atingir tais objetivos.

O Capítulo 2 é denominado "Estado da arte" e foi elaborado a partir de uma ampla revisão bibliográfica, enfocando o pilar misto parcialmente revestido e, posteriormente, a ligação entre este elemento estrutural e as vigas de aço, além de citar vários estudos já realizados sobre ligações viga-pilar. 


\section{2 | INTRODUÇÃO}

Também foram abordadas, no Capítulo 3, algumas normas técnicas e recomendações da literatura, destinadas ao dimensionamento e verificação de ligações entre pilares e vigas de aço, que foram aplicadas à tipologia de ligação estudada neste trabalho.

A descrição da metodologia adotada para o estudo da ligação viga-pilar misto é apresentada no Capítulo 4, destacando procedimentos empregados no decorrer do programa experimental desenvolvido, com o detalhamento dos modelos físicos, esquemas de ensaio, instrumentação, caracterização dos materiais e os resultados experimentais com a comparação destes com os resultados teóricos.

Para comparação com os resultados experimentais foram realizadas simulações numéricas das ligações viga-pilar misto, as quais foram abordadas no Capítulo 5, que apresenta as hipóteses consideradas na simulação numérica, a calibração dos modelos numéricos e o estudo paramétrico. Para todos os resultados apresentados, são realizados comentários e discussões a respeito do comportamento dos elementos, valores de capacidade resistente teórico e experimental, configurações de ruína, etc.

O Capitulo 6 traz as considerações finais deste trabalho, levando em consideração a análise comparativa dos resultados decorrentes das simulações numéricas e investigação experimental, conclusões e sugestões para novas pesquisas sobre o assunto.

Finalmente, as referências bibliográficas são citadas e os cálculos teóricos apresentados no Anexo A. 


\section{ESTADO DA ARTE}

\subsection{Generalidades}

Ao longo dos anos surgiram sistemas estruturais e construtivos que proporcionam à Construção Civil maior produtividade e racionalização, entre os quais se encontra a estrutura mista, cuja combinação de perfis de aço e concreto tem como objetivo aproveitar ao máximo as vantagens de cada material e minimizar suas desvantagens, tanto em termos estruturais como construtivos. A estrutura mista de aço e concreto possui um perfil de aço que trabalha em conjunto com o concreto, formando pilares mistos, vigas mistas, lajes mistas e até ligações mistas (Figura 2.1).

Figura 2.1 - Exemplos de elementos mistos de aço e concreto.

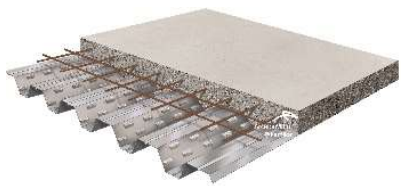

a) lajes mistas

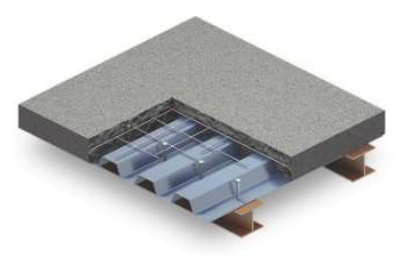

b) vigas mistas

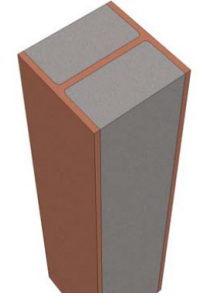

c) pilares mistos

Fonte: a) ARCELORMITTAL b) Matos (2015) c) Farias (2008).

A laje mista corresponde à laje de concreto com forma de aço incorporada. Existem variações relacionadas com espessura e formato geométrico (geralmente trapezoidal) da forma metálica e disposição desta em relação ao perfil da viga. Esse tipo de laje possui vantagens ao passo que se elimina o uso de fôrmas e se diminui a utilização de escoramentos.

Já a viga mista de aço e concreto é composta por um perfil de aço e por concreto, que pode ser a laje de concreto conectada ao perfil de aço ou uma camada de concreto revestindo parcialmente ou totalmente o perfil de aço.

Finalmente, os pilares mistos de aço e concreto são elementos estruturais sujeitos a esforços de compressão predominantemente, cuja seção transversal é formada por um perfil de aço e concreto trabalhando solidariamente.

Vale ressaltar que o comportamento misto é garantido quando dois elementos estruturais (aço e concreto) são interligados de tal forma a se deformarem como um único elemento. E, para que essa conexão ocorra, primeiramente, considera-se a aderência natural (adesão e atrito) proveniente das ligações físico-químicas que se desenvolvem na interface durante a hidratação 
do cimento e da força normal à superfície. Porém, no caso de estruturas mistas, ela não é suficiente para suportar as tensões de cisalhamento na interface. Portanto, torna-se necessário o uso de dispositivos mecânicos como conectores de cisalhamento, mossas ou saliências, por atrito ou ainda por meio de adesivos com resistência suficiente para absorver as tensões de cisalhamento que surgem na interação entre as interfaces dos elementos.

Para cada elemento estrutural há uma forma diferente de promover o comportamento conjunto, por exemplo, nas lajes mistas apenas a geometria da forma de aço incorporada e as saliências na superfície interna são suficientes para limitar os deslocamentos relativos entre os materiais, por outro lado nas vigas mistas são necessários conectores de cisalhamento, geralmente, soldados à mesa superior do perfil. Finalmente, no caso específico dos pilares mistos, ao longo do comprimento, as forças de atrito são suficientes para promover o comportamento conjunto, sendo apenas necessária a utilização de conectores de cisalhamento na região de introdução do carregamento para garantir a perfeita distribuição de tensões a todos os componentes da seção. Logo, fica evidente que a eficiência estrutural dos elementos mistos estará relacionada às características dos materiais que os compõem e às características da interface, como a rugosidade das superfícies.

\subsection{Pilar Misto Parcialmente Revestido}

Usualmente, os pilares mistos são classificados conforme a disposição do concreto na seção transversal. A ABNT NBR 8800 (2008) possui recomendações para quatro tipos de seções transversais de pilares mistos: seção revestida com concreto (Figura 2.2a), seção parcialmente revestida com concreto (Figura 2.2b), seção retangular preenchida com concreto (Figura 2.2c) e seção circular preenchida com concreto (Figura 2.2d), submetidos à compressão axial ou à flexocompressão. O pilar misto parcialmente revestido é a seção transversal estudada, que é composta por um perfil de aço, "I" ou "H", com a região entre as mesas preenchida por concreto (Figura 2.2b). O uso de armadura para prevenir fissuras, impedir o descolamento do concreto e contribuir em situações de incêndio é obrigatório (ABNT NBR 8800 (2008)). 
Figura 2.2 - Seções transversais de pilares mistos aço-concreto.

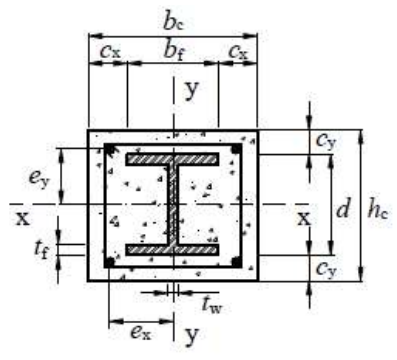

(a)

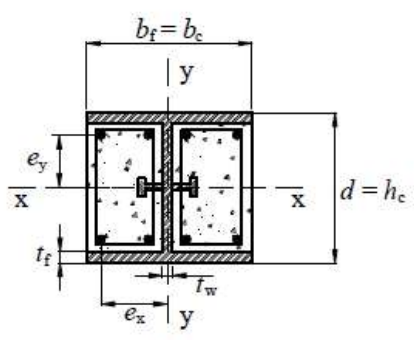

(b)

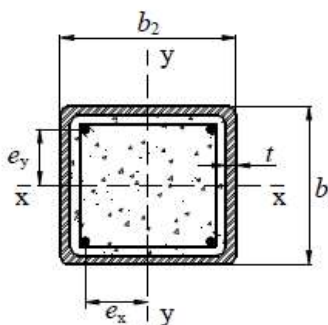

(c)

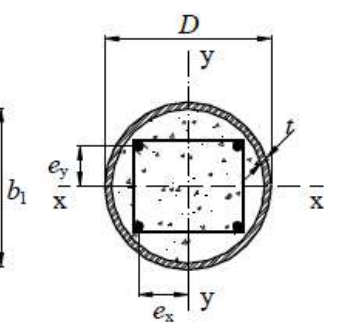

(d)

Fonte: ABNT NBR 8800 (2008).

As vantagens dos pilares mistos são referentes à resistência dos dois materiais (resistência à compressão do concreto e resistência à tração do aço), e da minimização das desvantagens referentes aos mesmos materiais (resistência à tração do concreto e instabilidade do perfil de aço). O concreto envolvendo o perfil de aço minimiza os problemas de flambagem do perfil, já o perfil pode aumentar a resistência do concreto devido ao efeito do confinamento.

O processo construtivo de pilares mistos apresenta também diversas vantagens, o perfil de aço é responsável por resistir ao peso próprio da estrutura, permitindo a construção dos pavimentos superiores, enquanto ainda é realizada a concretagem dos pavimentos inferiores. Após o preenchimento e o endurecimento do concreto, a estrutura mista passa a resistir em conjunto às ações de serviço atuantes na estrutura. Em edifícios de vários pavimentos, isso significa uma economia de tempo de construção.

Já o pilar misto parcialmente revestido possui vantagens da pré-fabricação e redução de desperdício de materiais, da facilidade na execução das formas e concretagem, da maior capacidade resistente e resistência ao fogo em relação ao pilar de aço e da redução do custo global. A sua eficiência estrutural possibilita a redução das dimensões dos elementos estruturais, e assim, a economia de material.

Vários estudos analisaram o confinamento do concreto pelo perfil de aço e seus benefícios ao concreto, tais como: aumento da capacidade resistente e maior capacidade de deformação. Em pilares mistos submetidos a uma força de compressão axial, o concreto sofre um encurtamento longitudinal e também uma expansão lateral. Esta expansão pode ser restringida pelo perfil de aço, dependendo de alguns fatores como a espessura do perfil, a excentricidade de carregamento, a resistência dos materiais e a seção transversal. Por exemplo, as seções retangulares possuem uma eficiência do confinamento menor que a seção circular e o concreto com baixa resistência apresenta uma maior expansão lateral que os de alta 
resistência, sendo o mais beneficiado pelos efeitos do confinamento. Além disso, já foi estudada a pressão lateral de confinamento exercida por armaduras transversais. Neste caso, a pressão de confinamento não é uniforme, ocorrendo concentração de tensões nos pontos de encontro entre as armaduras longitudinal e transversal. Um aspecto importante no processo construtivo dos pilares mistos parcialmente revestidos é o uso de armaduras longitudinal e transversal para garantir a integridade do concreto. Segundo a ABNT NBR 8800 (2008), as armaduras transversais devem ser ancoradas no perfil de aço através de solda ou furos na alma e o seu posicionamento dificulta o processo construtivo devido, principalmente, à necessidade de ancorá-las à alma do perfil de aço, interferindo também no perfeito adensamento do concreto de revestimento. Portanto, há a necessidade de estudos que apresentem alternativas de simples execução para garantir a integridade do concreto de revestimento.

O concreto com adição de fibras é um material constituído pela matriz de concreto e fibras descontínuas distribuídas aleatoriamente que podem ser fibras sintéticas ou fibras de aço para o reforço do concreto. As primeiras controlam as microfissuras prematuras do concreto enquanto as fibras de aço minimizam também o comportamento frágil característico do concreto. No concreto simples, o surgimento de uma fissura gera uma barreira para a propagação de tensões, ocasionando a concentração de tensões na extremidade da fissura que é responsável pela baixa resistência à tração do material. O concreto se rompe abruptamente, assim que a deflexão correspondente à resistência à flexão última é excedida. Já o concreto reforçado com fibras continua a suportar cargas significativas até mesmo com deformações consideravelmente maiores do que a deflexão na fratura do concreto simples, aumentando a tenacidade. As fibras servem como ponte de transferência de tensões entre as fissuras, controlando a propagação e a abertura das fissuras, logo o concreto passa a ter um comportamento pseudo-dúctil e pode ser utilizado para garantir a integridade do material (PEREIRA, 2017).

As fibras dispersas possuem algumas vantagens sobre as barras e malhas de aço: são distribuídas em três dimensões, apresentando distribuição de carga eficiente; são menos sensíveis à corrosão que as barras de aço e podem reduzir o custo da mão de obra para lançamento das barras e malhas de aço. A fração volumétrica, aderência à matriz, o tipo de fibra e seu comprimento têm um efeito significativo nas propriedades do concreto reforçado com fibras. A baixa fração volumétrica $(<1 \%$ ), por exemplo, pode diminuir a fissuração por retração. Já a fração volumétrica moderada (entre 1 e 2\%) aumenta o módulo de ruptura, tenacidade à fratura e a resistência ao impacto. A alta fração volumétrica $(>2 \%)$ leva ao 
endurecimento por deformação dos compósitos. Do ponto de vista estrutural, deve-se otimizar a aderência entre a fibra e a matriz. Se as fibras tiverem baixa aderência com a matriz, podem escorregar sob carregamentos baixos e não contribuem muito para reduzir a fissuração. Entretanto, se a aderência à matriz for muito alta, as fibras podem se romper antes de dissipar energia. Por fim, para diminuir o grande número de microfissuras e para evitar grande deformação localizada, é necessário ter um grande volume de fibras curtas. A distribuição aleatória de fibras curtas pode aumentar a resistência e a ductilidade do concreto (MEHTA; MONTEIRO, 2008).

A seguir são apresentadas algumas investigações sobre o pilar misto parcialmente revestido (Tabela 2.1), sendo possível verificar o que tem sido estudado sobre o assunto. De Nardin et al. (2012) estudou o uso do pilar misto parcialmente revestido em galpões industriais como alternativa aos pilares de aço e pré-moldados. Assim, analisaram 18 configurações de um galpão de $60 \mathrm{~m}$ de comprimento, considerando os parâmetros: tipo do pilar, altura, vão e condição de vinculação. Os elementos estruturais foram dimensionados segundo as normas ABNT NBR 8800 (2008) e ABNT NBR 6118 (2003). Os autores concluíram que geralmente o uso de pilares mistos possibilitava uma redução nas dimensões da seção transversal e nos custos em comparação aos pilares de aço e pilares pré-moldados.

Pereira (2017) estudou o comportamento estrutural de pilares mistos parcialmente revestidos submetidos à compressão simples e flexocompressão, avaliando a viabilidade da substituição da armadura convencional por alternativas com execução mais simples. Para isto, foram realizados 23 ensaios de pilares mistos fabricados com o perfil laminado W $150 \times 22,5$ com dois valores de comprimento e três configurações de armadura: armadura convencional soldada, tela de aço soldada entre as mesas do perfil e concreto com adição de fibras (Figura 2.3). Concluiu-se que o comportamento estrutural de pilares submetidos a forças excêntricas depende do eixo de flexão, de modo que a ruptura ocorre de modo mais abrupta quando submetida à flexão em torno do eixo de menor inércia. Além disso, obteve-se respostas similares para as três configurações de armadura avaliadas, e assim, a substituição da armadura convencional por telas de aço ou concreto com fibras de aço não alterou significativamente os valores de força máxima resistente nem o comportamento pós-pico. 
Figura 2.3 - Configurações estudadas de pilares mistos aço-concreto.
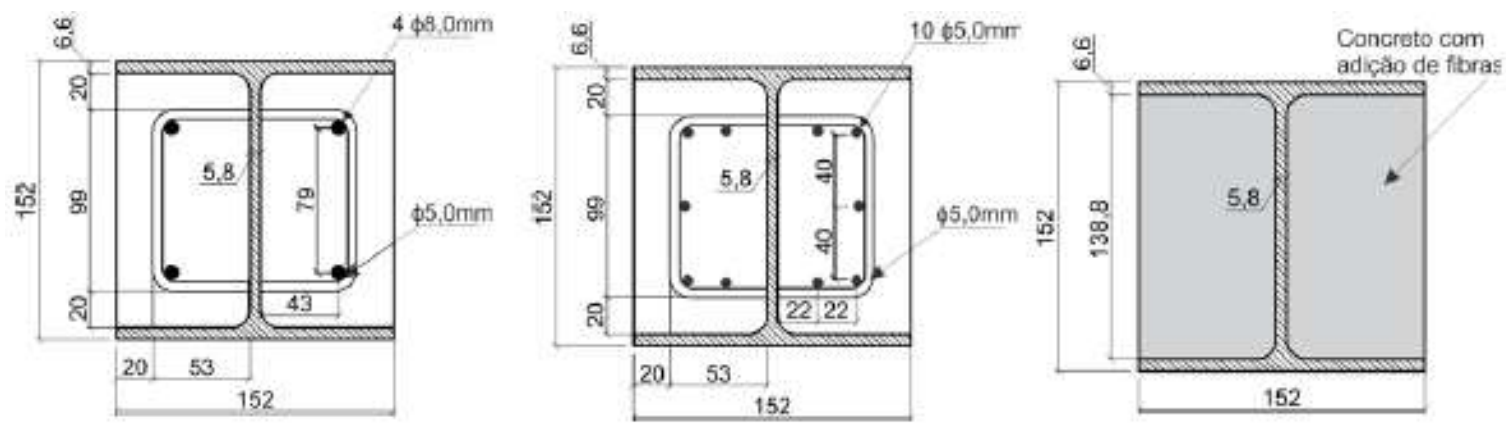

Fonte: Pereira (2017).

Tabela 2.1 - Alguns estudos de pilares mistos parcialmente revestidos.

\begin{tabular}{|c|c|c|c|c|}
\hline Autor & Ano & Carregamento & $\begin{array}{l}\text { Parâmetros } \\
\text { Estudados }\end{array}$ & Conclusões \\
\hline $\begin{array}{l}\text { Hunaiti } \\
\text { Fattah }\end{array}$ & 1994 & $\begin{array}{l}\text { Axial centrado e } \\
\text { excêntrico no eixo de } \\
\text { menor inércia. }\end{array}$ & $\begin{array}{l}\text { Conectores de } \\
\text { cisalhamento; } \\
\text { Chapas soldadas } \\
\text { entre as mesas; } \\
\text { Resistência do } \\
\text { concreto. } \\
\end{array}$ & $\begin{array}{c}\text { Pouca influência dos conectores } \\
\text { de cisalhamento; } \\
\text { A resistência do concreto não } \\
\text { aumentou significativamente a } \\
\text { capacidade resistente da seção } \\
\text { mista. }\end{array}$ \\
\hline $\begin{array}{l}\text { Tremblay } \\
\text { et al. e } \\
\text { Chicoine } \\
\text { et al. }\end{array}$ & $\begin{array}{l}1998 \\
2002\end{array}$ & Axial centrado. & $\begin{array}{l}\text { Modo de falha; } \\
\text { Espaçamento da } \\
\text { armadura } \\
\text { transversal. }\end{array}$ & $\begin{array}{c}\text { Com a armadura transversal } \\
\text { soldada entre as mesas, há um } \\
\text { ganho de rigidez e ductilidade; } \\
\text { O espaçamento entre as barras } \\
\text { não deve ser maior que metade da } \\
\text { altura da seção. }\end{array}$ \\
\hline $\begin{array}{l}\text { Prickett } \\
\text { Driver }\end{array}$ & 2006 & $\begin{array}{l}\text { Axial centrado e } \\
\text { excêntrico. }\end{array}$ & $\begin{array}{l}\text { Resistência do } \\
\text { concreto; } \\
\text { Eixo de inércia. }\end{array}$ & $\begin{array}{l}\text { Modo de falha depende do eixo } \\
\text { de flexão, é mais dúctil no eixo } \\
\text { de maior inércia devido ao } \\
\text { confinamento das mesas; } \\
\text { Baixa resistência do concreto } \\
\text { apresenta um comportamento } \\
\text { mais dúctil. }\end{array}$ \\
\hline Rocha & 2016 & Altas temperaturas. & $\begin{array}{l}\text { Campos térmicos } \\
\text { uniformes e não } \\
\text { uniformes. }\end{array}$ & $\begin{array}{l}\text { Pilares mistos têm um ganho de } \\
70 \text { min na resistência ao fogo em } \\
\text { relação ao pilar de aço; } \\
\text { Pilar inserido na parede possui } \\
\text { maior resistência ao fogo; } \\
\text { Aquecimento não uniforme gera } \\
\text { momentos no pilar. }\end{array}$ \\
\hline
\end{tabular}

Fonte: Elaborado pela autora. 


\subsection{Ligações Metálicas e Mistas Viga-Pilar}

Apesar das vantagens dos elementos mistos em aspectos estruturais, construtivos e econômicos, como já apresentado, a principal preocupação com estes elementos está associada à ligação do elemento misto com outros elementos estruturais. Segundo Cavalcante et al. (2014), o termo ligação é aplicado a todos os detalhes construtivos que promovam a união de elementos estruturais entre si ou a união desses com elementos externos, permitindo a transmissão de esforços. Devido à variedade de elementos de aço, faz com que a ABNT NBR 8800 (2008) não apresente fórmulas diretas para o dimensionamento de ligações viga-pilar, sendo necessário o estudo individualizado para cada tipo de ligação. É possível encontrar algumas sugestões na literatura técnica, porém tais sugestões, em sua maioria, foram desenvolvidas para situações envolvendo ações sísmicas. Mas, os detalhes estudados serviram de inspiração para o desenvolvimento de tipologias de ligação viga-pilar misto aplicáveis à realidade brasileira.

Um outro fator importante é a representatividade do custo da ligação em relação ao custo da estrutura como um todo. No caso de estruturas de aço, o custo das ligações representa até $50 \%$ do seu custo total e este fator, por si só, já torna imprescindível o desenvolvimento de dispositivos de ligação estruturalmente eficientes, de fácil execução e baixo custo. Assim, um dispositivo de ligação deve ser concebido e dimensionado considerando os seguintes aspectos: capacidade resistente, capacidade de rotação e rigidez adequadas, facilidade de execução e montagem e, custo reduzido. Os detalhes de ligações viga-pilar em estruturas mistas dependem de vários fatores:

- Tipo de pilar misto (revestido, preenchido ou parcialmente revestido);

- Tipo de viga (viga mista, de aço ou de concreto);

- Comportamento esperado para a ligação (rígida ou flexível);

- Posição relativa entre o pilar e a viga (ligação no eixo de maior ou menor inércia do pilar).

Para Queiroz (1993), as ligações podem ser flexíveis, rígidas e semirrígidas. As ligações flexíveis viga-pilar, nas quais as rotações relativas são livres entre os elementos, possuem a característica de transmissão de força cortante entre a viga e o pilar, desprezando a transferência de momentos fletores entre os elementos. Já na ligação rígida, não há rotações relativas 
significativas entre os elementos e há transferência total de momentos fletores das vigas para os pilares. Por fim, na ligação semirrígida, as rotações relativas entre os elementos e a transferência de momentos fletores são parciais.

O comportamento mecânico das ligações influencia na distribuição dos esforços e nos deslocamentos das estruturas, tornando-se necessário o conhecimento da rigidez rotacional, da capacidade de rotação e do momento resistente da ligação. O momento resistente quantifica a capacidade da ligação em transferir momento fletor da viga para o pilar, já a capacidade de rotação possibilita a redistribuição de momentos. Conhecer a curva momento-rotação da ligação e desenvolver modelos aproximados de cálculo são essenciais para o projeto, mas difíceis devido à complexidade do mecanismo de transferência de esforços.

O conhecimento da rigidez das ligações é essencial para a análise elástica das estruturas e o conhecimento da capacidade resistente e de rotação das ligações para a análise plástica. Dessa forma as ligações deverão ser dimensionadas conforme as hipóteses adotadas para os nós das barras na análise estrutural, ou seja, nos locais onde foram supostas ligações rígidas, deverão apresentar detalhes que impeçam a rotação relativa das partes, assim como nos locais onde a ligação permiti a rotação relativa das partes, os detalhes deverão garantir essa rotação com o mínimo de restrição. De acordo com o grau de restrição da rotação relativa de suas partes, as ligações são classificadas por:

$\mathrm{Na}$ ligação rígida, o ângulo entre os elementos estruturais que se interceptam permanece o mesmo após o carregamento da estrutura. A partir dos limites estabelecidos pela ABNT NBR 8800 (2008) uma ligação viga-pilar pode ser considerada rígida pela Inequação 2.1, a seguir:

$$
S_{i} \geq \frac{25 E I_{v}}{L_{v}}
$$

Essa condição é válida somente para estruturas nas quais, em cada andar, a seguinte condição é satisfeita (Inequação 2.2):

$$
\frac{K_{v}}{K_{p}} \geq 0,1
$$

Onde, $\mathrm{S}_{\mathrm{i}}$ é a rigidez inicial da ligação correspondente a $2 / 3$ do momento resistente de cálculo da ligação; $\mathrm{I}_{\mathrm{V}}$ é o momento de inércia da seção transversal da viga conectada no plano da estrutura; $L_{V}$ é o comprimento da viga conectada; $K_{v}$ é o valor médio de $I_{v} / L_{v}$ para todas as vigas do andar; $\mathrm{K}_{\mathrm{p}}$ é o valor médio de $\mathrm{I}_{\mathrm{p}} / \mathrm{L}_{\mathrm{p}}$ para todos os pilares do andar; $\mathrm{I}_{\mathrm{p}}$ é o momento de inércia da seção transversal do pilar conectada no plano da estrutura; $\mathrm{L}_{\mathrm{p}}$ é a altura do andar para 
um pilar. Os valores de $\mathrm{S}_{\mathrm{i}}$ podem ser determinados de acordo com o Eurocode 3 Part 1-8 ou com base em resultados experimentais.

Caso a primeira condição seja satisfeita, mas a segunda não, a ligação deve ser considerada semirrígida. Nesse caso, o momento transmitido através da ligação não é próximo de zero como no caso de ligações flexíveis e nem próximo do momento máximo como no caso de ligações rígidas. Para que se possa utilizar a ligação semirrígida, deverá ser conhecido a relação de dependência entre o momento resistente e a rotação.

Na ligação flexível, a restrição à rotação relativa entre os elementos estruturais deve ser tão pequena quanto se consiga obter na prática. Por exemplo, em vigas sujeitas à flexão simples, a ligação flexível só transmite a força cortante. A partir dos limites estabelecidos pela ABNT NBR 8800 (2008) uma ligação viga-pilar pode ser considerada rotulada pela Inequação 2.3:

$$
S_{i} \leq \frac{0,5 E I_{v}}{L_{v}}
$$

O Eurocode 3 (2005) apresenta os mesmos limites para classificar uma ligação vigapilar e considera mais uma condição para uma ligação rígida: $\mathrm{k}_{\mathrm{b}}$ é 8 ao invés de 25 para estruturas em que o contraventamento reduz o deslocamento horizontal em $80 \%$. Além disso, é possível classificar a ligação quanto à sua resistência:

- Resistência total: A ligação tem o momento resistente maior ou igual que ao dos elementos conectados (momento resistente da viga), formando rótulas plásticas nos elementos e não na ligação;

- Resistência parcial: O momento resistente da ligação é menor que dos elementos conectados (momento resistente da viga), formando inicialmente rótulas plásticas nas ligações;

- Rotuladas: A ligação só transmite esforços normais e de cisalhamento.

A influência dos componentes da ligação se dá pela relação entre a força e a deformação de cada componente e pelos braços de alavanca entre os componentes. Tanto a relação entre a força e a deformação quanto os braços de alavanca são influenciados pela configuração da ligação. Já a configuração influencia a rigidez inicial, a capacidade resistente e rotacional. Em geral, cada componente possui um comportamento força-deformação não linear, além disso, o quanto e como cada componente contribui para o comportamento global da ligação depende da sua posição em relação à linha neutra, mas assume-se que o comportamento isolado de um 
componente sob um carregamento específico será sempre igual, independentemente de sua posição ou arranjo na ligação.

Nas estruturas metálicas existem várias configurações de ligações entre vigas e pilares, buscando sempre a rigidez rotacional adequada para cada projeto. Em pilares mistos parcialmente revestidos a execução das ligações é feita, normalmente, no perfil de aço. Para ligações viga-pilar no eixo de maior inércia, o pilar é o elemento continuo e as vigas são conectadas a ele por meio da mesa exposta do perfil de aço. É possível utilizar diferentes tipos de configurações como mostrados na Figura 2.4.

Figura 2.4-Possibilidades de ligações viga-pilar.
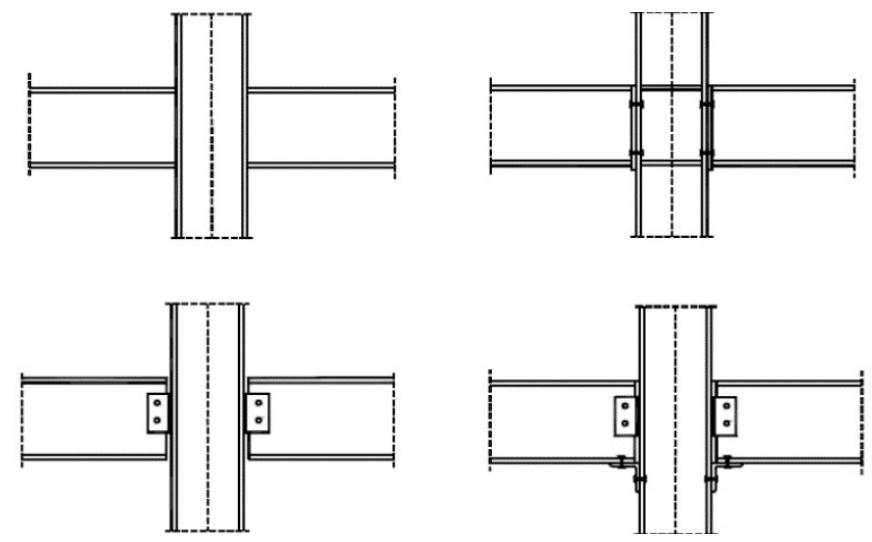

Fonte: Figueiredo (2004).

Estudos mostram que os parâmetros internos mais influentes no comportamento da ligação são: altura da viga de aço e tipo de ligação. Em relação à altura da viga de aço, a variação da altura da viga aumenta significativamente os valores de momento resistente e de rigidez rotacional. Isto ocorre porque o aumento da altura da viga gera um acréscimo do braço de alavanca entre as componentes de tração e de compressão. Por outro lado, ocorre a redução da capacidade de rotação.

Já a ligação com chapa de topo tem maior rigidez inicial e momento resistente enquanto que a ligação com dupla cantoneira de alma apresenta maior capacidade de rotação. A maior rigidez e o maior momento resistente na ligação com chapa de topo ocorrem porque a linha superior de parafusos encontra-se na região tracionada e liga as mesas da viga ao pilar, contribuindo para a resultante de tração. Além disso, as forças de compressão são transferidas por contato direto entre a chapa de topo e o pilar e, devido ao maior valor da resultante de tração e do braço de alavanca, a rigidez é maior em relação à ligação com cantoneiras de alma.

As cantoneiras de mesa e de alma são geralmente usadas devido ao baixo custo de fabricação e montagem, entretanto, não proporcionam a mesma continuidade que as ligações 
com chapa de topo ou soldadas. Logo, o uso de cantoneiras em ligações de aço leva ao aumento das dimensões da viga. Neste tipo de ligação, o espaço entre a extremidade da viga e o pilar e a redução do braço de alavanca entre os parafusos reduzem a rigidez de tais ligações que podem ser consideradas rotuladas.

Um aumento da rigidez da ligação irá ocorrer apenas se a rotação for grande o suficiente para eliminar o espaço existente entre a mesa inferior da viga e o pilar, transferindo as forças de compressão diretamente para o pilar por contato viga-pilar, contudo, a rotação, para que isto ocorra, é excessiva. Conforme a Figura 2.5, o comportamento da ligação com cantoneira de alma pode ser modificado com a inclusão de cantoneiras de assento ou chapas de contato, que permitem a transferência das forças de compressão, e com a consideração da laje, na qual a armadura faz a transferência das forças de tração (ligação mista). Grande parte da deformação verificada nas cantoneiras de alma deve-se à flexão, ao contato dos parafusos e ao escorregamento causado pelo alargamento dos furos (DE NARDIN; EL DEBS, 2012).

Figura 2.5 - Ligações mistas viga-pilar com cantoneiras.

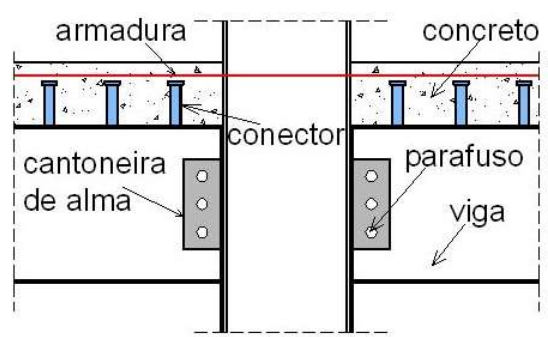

a) Ligação com cantoneiras de alma

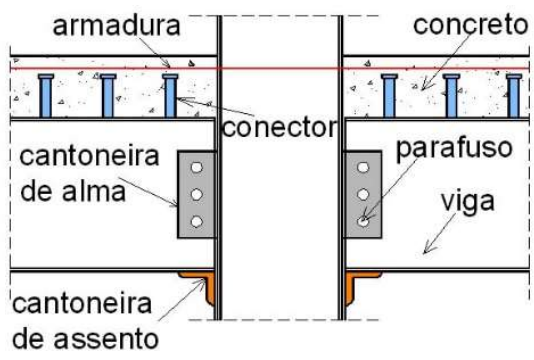

b) Ligação com cantoneiras de alma e de assento

Fonte: De Nardin e El Debs (2012).

Fatores externos à região de ligação também influenciam o comportamento das ligações. Por exemplo, o grau de interação entre a viga de aço e a laje de concreto e a presença da laje, o tipo de carregamento (estático, dinâmico, balanceado ou não), a posição da ligação na estrutura e o método construtivo (construção escorada ou não escorada) são parâmetros importantes. Há uma dificuldade na execução de ligações viga-pilar no eixo de menor inércia em estruturas de múltiplos pavimentos. Neste caso, a concretagem, normalmente executada na horizontal, deve ser interrompida na região da ligação para se ter acesso ao perfil de aço, e assim, poderá ser executada. Com esta interrupção, muitas vezes é necessário o uso de conectores de cisalhamento para garantir o comportamento conjunto dos elementos estruturais. 
Muise (2000) estudou uma configuração de ligação no eixo de menor inércia para pilares mistos parcialmente revestidos com chapas esbeltas de aço. A ligação é feita utilizando-se uma chapa de topo exterior soldada como indicada na Figura 2.6. Como não é interrompido o revestimento de concreto, não há a necessidade de mecanismos de ancoragem, como conectores de cisalhamento, para as situações estudadas. Segundo Muise (2000), precauções extras devem ser tomadas para casos com momento aplicado ou forças horizontais. Nesta área, há uma carência de estudos que possibilitem detalhes de ligações mais práticos e eficientes.

Figura 2.6 - Ligação no eixo de menor inércia.

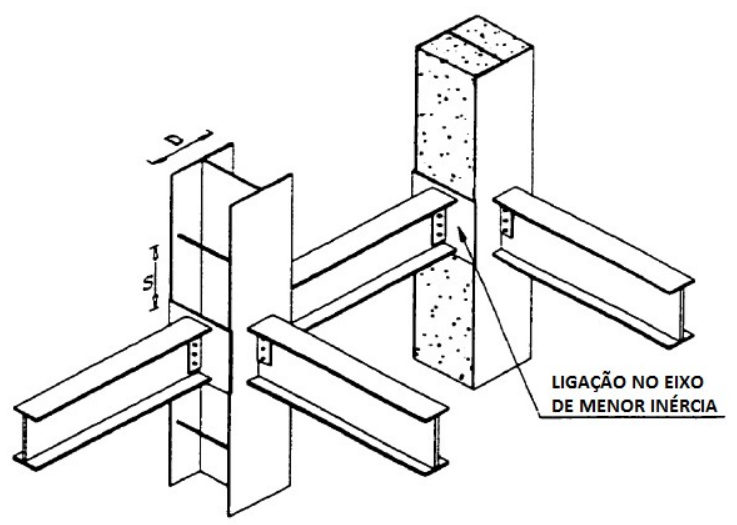

Fonte: Muise (2000).

Nas últimas décadas, algumas pesquisas vêm sendo desenvolvidas no que tange às ligações metálicas e mistas, uma vez que alguns resultados exploratórios têm mostrado que a laje pode contribuir significativamente na transferência de momento fletor, fornecendo a continuidade de momento fletor entre as vigas sem solicitação do elemento suporte. Dentre as quais divididas em função do tipo de pilar, podem-se destacar as ligações descritas a seguir.

\subsubsection{Tipologias de Ligações no Contexto Local}

Os detalhes de ligações disponíveis na literatura internacional para os pilares preenchidos são, na maioria, desenvolvidos para perfis tubulares laminados, entretanto no Brasil, os perfis tubulares são usualmente obtidos da associação de dois perfis U. Algumas alternativas mais apropriadas à realidade brasileira foram estudadas por De Nardin (2003) e estão indicadas na Figura 2.7. A tipologia (a) é chamada ligação por chapa de topo e parafusos passantes, e em seus estudos De Nardin (2003) comparou situações com aderência entre os parafusos e o núcleo de concreto e sem aderência entre eles. Verificou-se que a existência de aderência não alterava a capacidade resistente, entretanto ocorriam alterações nas distribuições 
de deformação na chapa de topo. Ligações soldadas também foram avaliadas (b e c) e verificouse que a adição de cantoneiras internas na região tracionada da ligação viga-pilar preenchido contribuiu para o aumento da rigidez e da capacidade resistente e para a redução das deformações.

Figura 2.7 - Ligações propostas para pilares mistos preenchidos.

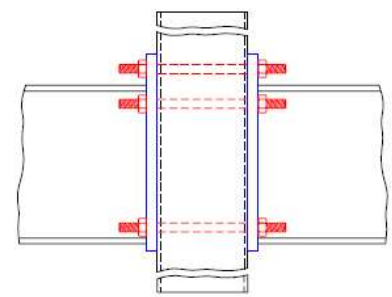

a) ligação parafusada - chapa

de extremidade + barras rosqueadas

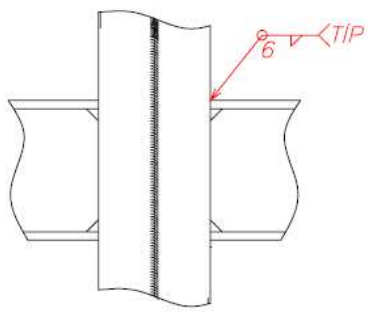

b) ligação soldada

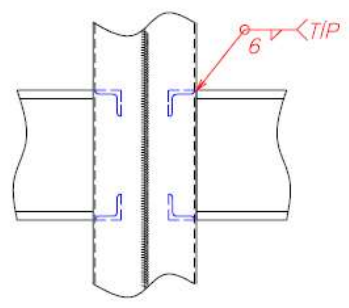

c) ligação soldada +

cantoneiras enrijecedoras

Fonte: De Nardin (2003).

Farias (2008) analisou a influência da laje de concreto armado e o mecanismo de transferência de forças com o mesmo detalhe de ligação viga-pilar misto do trabalho De Nardin (2003), constituída por uma viga de aço unida a um pilar misto preenchido através de barras rosqueadas, mediante a um estudo experimental e uma modelagem numérica. Para isso foram ensaiados três modelos que se diferenciam pela ausência ou tipo de conector de cisalhamento presente na região interna do pilar misto. Os resultados experimentais mostraram que a ruptura da ligação foi determinada pela laje, associada ao escoamento da armadura longitudinal sem que a ligação viga-pilar fosse comprometida. $\mathrm{O}$ uso dos conectores de cisalhamento no pilar misto não interferiu de forma significativa no comportamento do modelo, mas apresentaram desempenho superior quanto à transferência de forças entre o núcleo de concreto e o perfil de aço.

Kataoka (2011) avaliou experimentalmente e numericamente o comportamento de ligações mistas viga-pilar compostas por chapas de topo com parafusos passantes entre pilares preenchidos com concreto e vigas mistas (Figura 2.8). A laje utilizada foi a laje mista com forma de aço incorporada, com a utilização de conectores de cisalhamento para resistir aos esforços em conjunto com a viga. Para simular a situação de pilar intermediário, foram utilizados modelos com formato cruciforme, os quais foram submetidos a força cíclica reversível com a finalidade de submeter a estrutura a esforços semelhantes aos provocados por vento e sismo. Além do efeito da força cíclica, este trabalho estudou também a influência da 
taxa de armadura da laje e do detalhe de ancoragem da armadura ao pilar misto na rigidez da ligação. Como resultado das análises, concluiu-se que a laje contribui mais na rigidez da ligação quando ela está submetida ao momento fletor positivo e com relação ao método de ancoragem não houve diferença significativa nas rigidezes.

Figura 2.8 - Modelos estudados de ligações e esquema de carregamento cíclico.

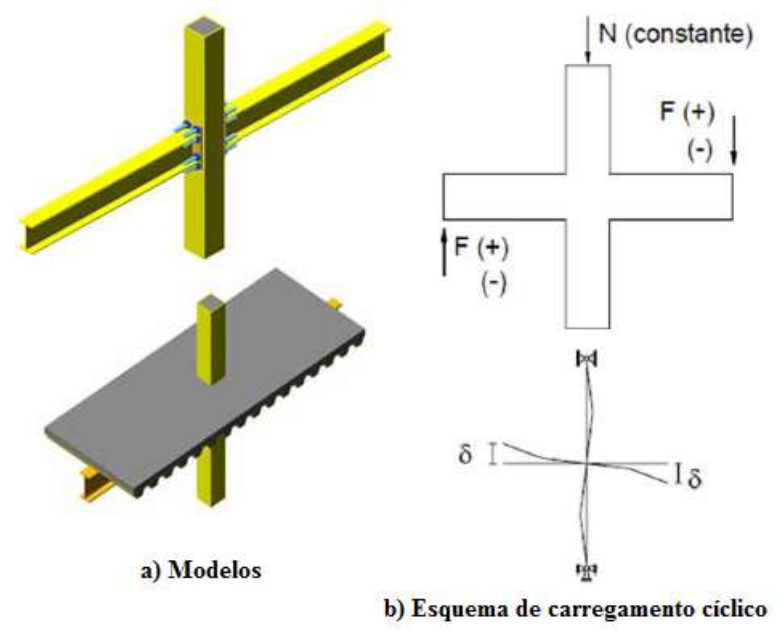

Fonte: Kataoka (2011).

De Nardin e El Debs (2012) apresentaram os resultados dos ensaios em escala real de ligação entre pilar misto e viga mista, incluindo os ensaios de ligação mista e metálica vigapilar. O sistema ensaiado consistia de um pilar misto preenchido e um piso misto de pequena altura, onde uma viga de aço assimétrica foi conectada por chapas passantes (Figura 2.9). Também foi realizado um ensaio viga-pilar sem a presença da laje para analisar a contribuição da laje na ligação. Os resultados mostraram a importância da laje no aumento da capacidade de momento na ligação, além disso, as extremidades das vigas mistas obtiveram maiores deslocamentos verticais em consequência de resistirem maiores carregamentos aplicados. A laje mista acrescentou capacidade resistente e rigidez à ligação. Dentro dos termos de rigidez, a ligação mista se comportou como semirrígida, enquanto a ligação metálica se comportou como uma articulação fixa. Não foram observadas significativas deformações nos parafusos. 
Figura 2.9 - Esquema de ensaio para ligação cruciforme.

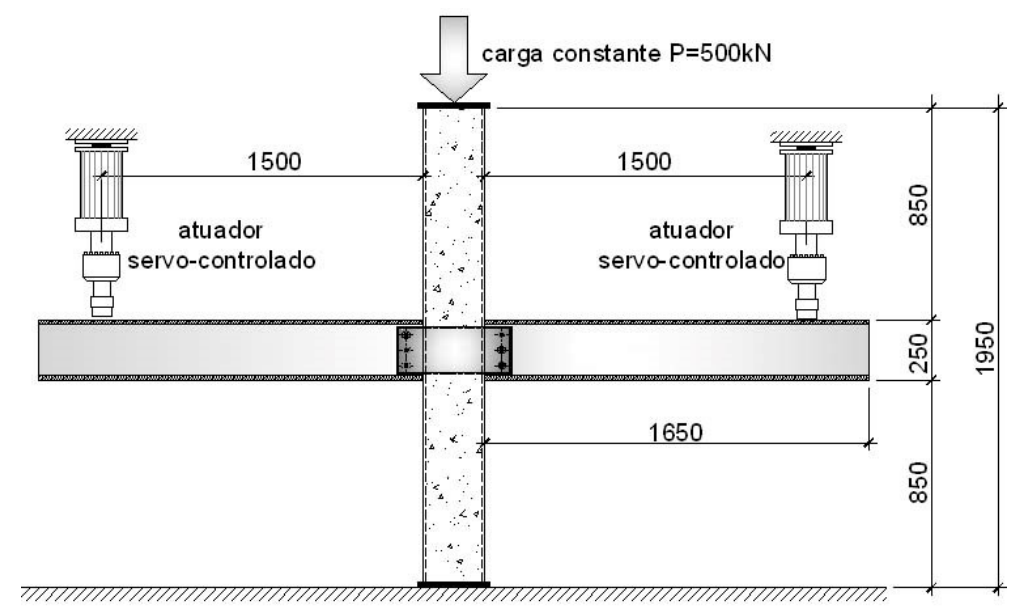

Fonte: De Nardin e El Debs (2012).

Em continuidade a esse estudo, Tineo e De Nardin (2017) desenvolveram um modelo numérico de ligação mista viga-pilar preenchido com chapa passante (Figura 2.10). Além do desenvolvimento do modelo, foram realizadas análises paramétricas com objetivo de avaliar a influência de parâmetros geométricos, tais como, a taxa de armadura da laje, os perfis de aço da viga mista e o diâmetro dos parafusos. O aumento da espessura da alma resultou em aumentos consideráveis de capacidade de momento. Assim, quanto maior a espessura da alma do perfil da viga mista maior é a capacidade de transmitir momento na ligação mista. Em relação ao momento máximo, quanto maior o diâmetro do parafuso, maior o valor do momento resistido pela ligação mista.

Figura 2.10 - Modelo numérico da ligação estudada.

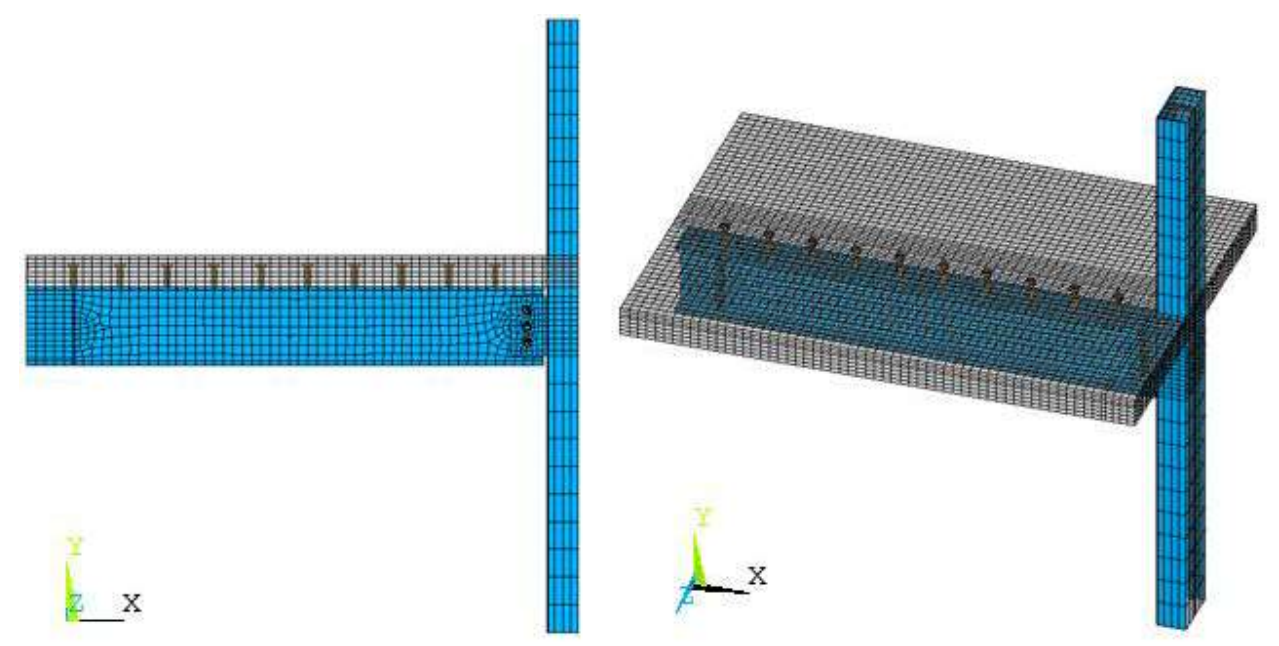

Fonte: Tineo e De Nardin (2017). 


\subsubsection{Ligações Viga-Pilar com Pilar de Aço}

As ligações rígidas podem não oferecer a solução mais econômica para edifícios de múltiplos andares por causa dos altos custos de fabricação. Já as ligações mistas semirrígidas podem resultar em redução de peso e de altura das vigas de aço. DHANALAKSHMI et al. (2002) relataram um ensaio que utilizou um novo detalhe de ligação viga-pilar exterior que atenua problemas de ancoragem da armadura, visto na Figura 2.11. Neste novo detalhe, a armadura foi passada através dos furos nas mesas do pilar, com suas extremidades dobradas a $90^{\circ}$. No eixo de menor inércia as vigas eram soldadas, já no eixo de maior inércia, a ligação viga-pilar era composta de chapa de topo e parafusos com armadura passante. A melhoria da ancoragem e da continuidade resultante do novo detalhe levou a um aumento da capacidade de rotação. Além disso, os furos nas mesas tinham o mesmo diâmetro de orifícios perfurados para parafusos e, portanto, não aumentavam significativamente os custos de fabricação. Os resultados mostraram que a nova ligação mista poderia resistir a momentos fletores significativos, embora tenha ficado aquém do esperado teoricamente.

Figura 2.11 - Detalhe da ancoragem da armadura.

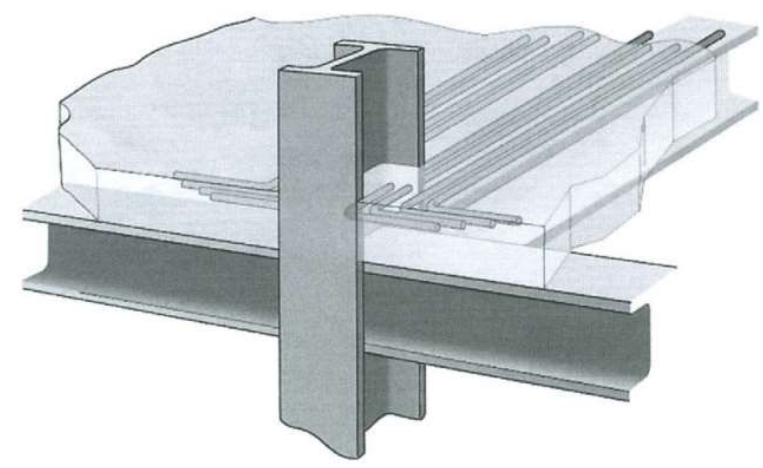

Fonte: Dhanalakshmi et al. (2002).

Bursi et al. (2005) avaliaram o desempenho sísmico de estruturas mistas resistentes a momento fletor compostas por vigas mistas com interação total e parcial, e pilares de aço (Figura 2.12). As análises paramétricas revelaram que as estruturas mistas com interação parcial demonstraram o mesmo comportamento com interação total sob carga sísmica severa. No entanto, o grau de interação deve ser alto o suficiente para impedir a ruptura dos conectores de cisalhamento na parte central de vigas mistas. Somente os conectores de cisalhamento nas extremidades das vigas mistas com interação total dissiparam energia da ligação viga-pilar enquanto que os conectores de cisalhamento na parte central contribuem para a dissipação de energia das vigas mistas. 
Figura 2.12 - Exemplo de ligação viga-pilar soldada com perfil $H$.

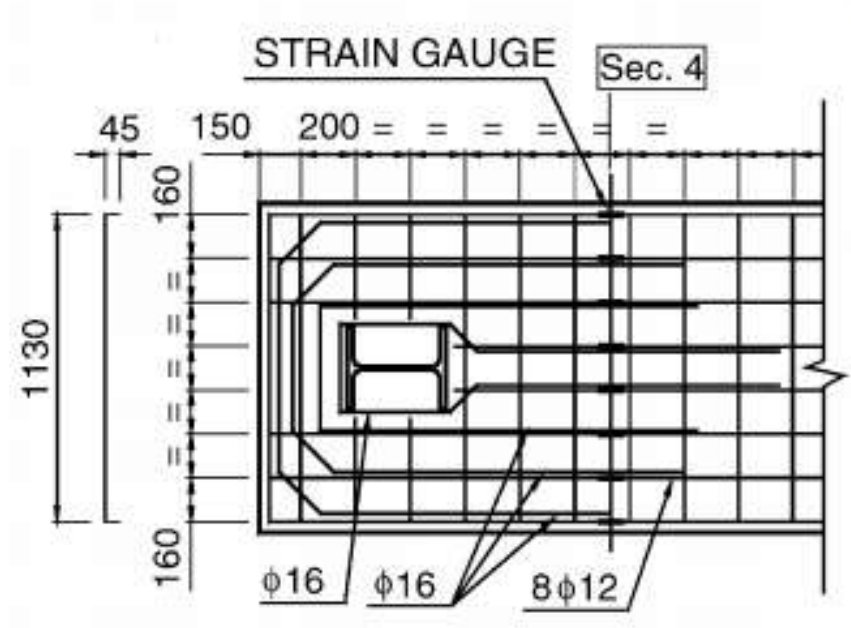

\section{Ligacão soldada viga-coluna}

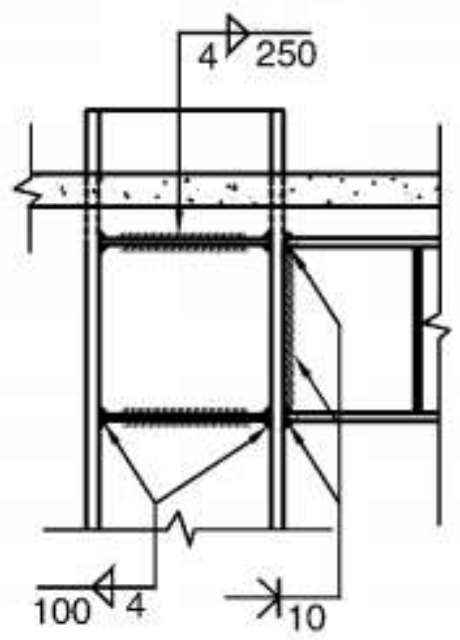

Fonte: Bursi et al. (2005).

Fu e Lam (2006) realizaram oito ensaios de ligações semirrígidas de viga-pilar com pilares e vigas de aço e lajes alveolares pré-moldadas (Figura 2.13). As variáveis estudadas foram o espaçamento dos conectores, o grau de interação, a armadura longitudinal e a espessura da laje. As ligações propostas forneceram capacidade de momento e capacidade de rotação suficientes. A partir dos resultados, concluíram que deve ser utilizado um grau de interação mínimo que permita a plena mobilização e escoamento da armadura longitudinal. Demonstrouse que a posição dos conectores tipo pino com cabeça desempenhou um papel importante na capacidade de rotação das ligações mistas viga-pilar. $O$ espaçamento do conector de cisalhamento próximo da face do pilar afetou o padrão de fissuras, logo, recomendou-se que o primeiro conector de cisalhamento seja posicionado com um espaçamento equivalente a duas vezes a largura do pilar. 
Figura 2.13 - Ligação mista com laje alveolar.

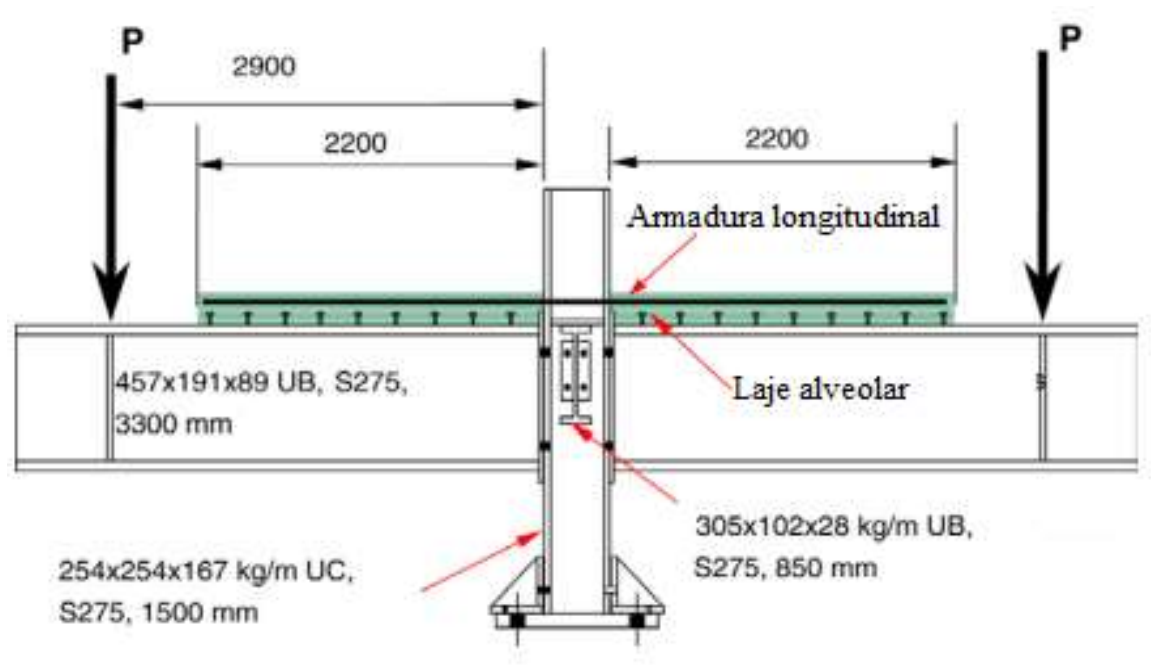

Fonte: Fum e Lam (2006).

Durante a última década, vários estudos têm sido realizados sobre colapso progressivo. Yang et al. (2016) conduziram quatro ensaios experimentais para estimar o comportamento de estruturas mistas formadas por vigas mistas e pilar de aço I e a resistência ao colapso com a ruína do pilar central. O mecanismo de transferência de esforços e a redistribuição de momento entre as ligações central e lateral foram investigados. Dois tipos de ligações, ou seja, cantoneira de alma e chapa de extremidade parafusada, foram estudados. Os ensaios experimentais indicam que a ação catenária pode ser desenvolvida nas estruturas internas e que pode aumentar a capacidade de carregamento das estruturas mistas significativamente, e que o modo de ruptura é controlado pela ruptura da ligação viga-pilar. Para ligações com cantoneira de alma e armadura adicional na laje, a capacidade de carregamento pode ser aumentada em $113 \%$ na fase de pequenas deformações e $84 \%$ na fase de grandes deformações. Já para ligações com chapa de extremidade e armadura adicional na laje, a capacidade de carregamento pode ser aumentada em 34\% na fase de pequenas deformações e 70\% na fase de grandes deformações. A armadura adicional pode promover o desenvolvimento dessa ação catenária, porém pode afetar a formação do arco compressivo que auxilia a capacidade resistente ao momento fletor positivo.

ATAEI et al. (2016) realizaram três ensaios de ligação viga-pilar com chapa de extremidade, com e sem laje pré-moldada em estruturas desmontáveis para avaliar a rigidez, a capacidade de momento e a capacidade de rotação, visando a reutilização e redução de resíduos na demolição, como pode ser visto na Figura 2.14. A rigidez dessa ligação permitiu que os momentos fletores fossem transmitidos na estrutura e sua ductilidade permitiu a redistribuição do momento fletor. De acordo com as normas EC3 (2005) e EC4 (2005), existem três possíveis 
modos de falha no elemento de aço da ligação: a) escoamento completo da chapa de extremidade ou da mesa do pilar, b) ruptura do parafuso com escoamento da chapa de extremidade ou mesa do pilar e c) ruptura do parafuso. Para evitar a ruptura frágil, as normas EC3 (2005) e EC4 (2005) recomendam que a espessura da chapa de extremidade não deve ser maior que $60 \%$ do diâmetro do parafuso. Apesar do projeto dessas duas ligações mistas vigapilar bem como da ligação metálica viga-pilar seguir essa recomendação, o modo de falha ocorreu por ruptura do parafuso e não por escoamento total. Em termos de resistência, a presença das lajes pré-moldadas foi significativa, pois a capacidade das ligações mistas vigapilar foi 2,5 vezes maior que da ligação metálica viga-pilar. Ensaios de push-out com conectores de cisalhamento parafusados foram feitos para verificar a resistência da ligação mista laje-viga. Os conectores de cisalhamento proporcionaram uma adequada ligação com as lajes prémoldadas. Pode-se observar que as ligações mistas viga-pilar com conectores de cisalhamento parafusados desmontáveis eram muito dúcteis e satisfaziam os requisitos especificados pela EC3 (2005) e pela EC4 (2005).

Prosseguindo com o estudo, ATAEI et al. (2017) apresentaram uma modelagem tridimensional em elementos finitos dessa ligação mista viga-pilar com chapa de extremidade e conectores de cisalhamento parafusados. A curva momento versus rotação para esse modelo com a influência da interação parcial laje-viga foi investigado usando o software ABAQUS. Um estudo paramétrico foi conduzido, analisando alguns parâmetros como o grau de interação, espessura da laje pré-moldada, espaçamento entre os conectores de cisalhamento parafusados, dimensões dos parafusos na zona de ligação, espessura da chapa de extremidade e espessura da mesa do pilar. Verificou-se que à medida que o grau de conexão cisalhamento aumenta acima de um certo nível (54\%), a rigidez inicial da ligação mista viga-pilar aumenta significativamente. No entanto, o aumento da rigidez inicial é acompanhado da redução significativa da capacidade de rotação da ligação e com a ligeira redução da capacidade de momento. Já uma ligação mista viga-pilar com um grau de interação parcial de $34 \%$ mostra ductilidade e resistência limitadas devido à ruptura do conector de cisalhamento parafusado. Pôde-se concluir que um grau mínimo de interação (cerca de 50\%) deve ser utilizado para evitar a ruptura desses conectores de cisalhamento parafusados. Os resultados mostraram que a capacidade de momento e a capacidade de rotação não são influenciadas significativamente pelo espaçamento entre os conectores de cisalhamento parafusados. À medida que a espessura 
da laje aumenta, o deslizamento final na interface diminui, a capacidade de momento e rigidez inicial aumentam, mas a capacidade de rotação diminui.

Figura 2.14 - Esquema da ligação mista desmontável a) Esquema ilustrativo b) Seção transversal da viga mista com conectores de cisalhamento parafusados PFGBSC.

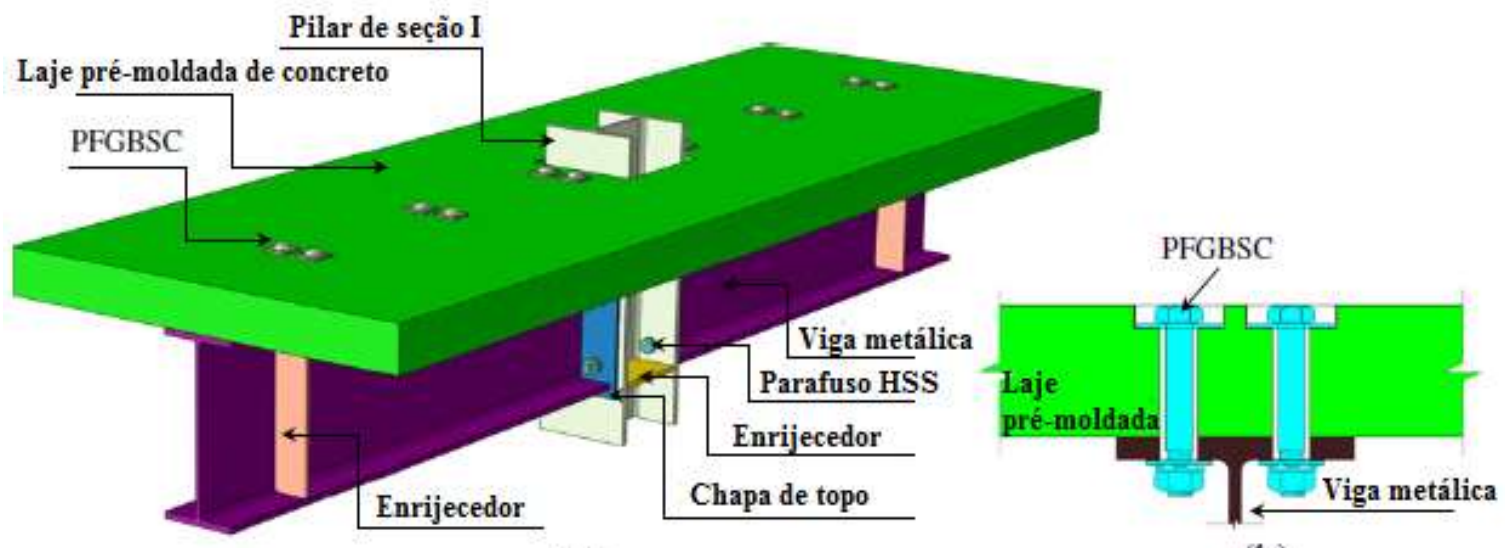

(a)

Fonte: Ataei et al. (2017).

Pôde-se observar um aumento da capacidade de rotação e de momento com o aumento do diâmetro do parafuso. No entanto, o aumento do diâmetro do parafuso acima de $24 \mathrm{~mm}$ pode ter um ligeiro efeito sobre a resistência e ductilidade da ligação mista. Para completo escoamento da chapa de extremidade, a razão da espessura da chapa de topo e do diâmetro do parafuso não deve ser superior a 0,5 e não 0,6 para esse tipo de ligação. Portanto, a espessura da chapa de extremidade deve ser limitada a fim de evitar a ruptura frágil dos parafusos na zona de ligação.

Pode ser visto que à medida que a espessura da mesa do pilar aumenta, tanto a rigidez inicial quanto a capacidade de momento aumentam. Contudo, quando a espessura da mesa excede um certo valor (18 mm neste estudo), a capacidade de momento não aumenta. Em contraste, a capacidade de rotação diminui à medida que a espessura da mesa aumenta, mas este parâmetro permanece quase constante quando a espessura da mesa excede um determinado valor. Isso pode ocorrer, pois a espessura da mesa do pilar é muito maior do que a da chapa de topo.

Lu et al. (2017) desenvolveram uma ligação viga-pilar que é apropriada para o eixo de menor inércia do pilar de seção I e viga de aço de seção H, conforme a Figura 2.15. Dez modelos de ligações cruciformes, incluindo cinco modelos com ligações metálicas e cinco com ligações mistas com laje e com interação parcial, foram ensaiados sob reversão de cargas para avaliar o efeito da ação mista sobre as ligações no eixo de menor inércia. Apenas uma pequena 
degradação da resistência ocorreu nas ligações mistas em comparação com as ligações metálicas, as ligações mistas têm um comportamento mais estável. A boa qualidade de solda é uma garantia importante para evitar a ruptura frágil das ligações e permitir o desenvolvimento de deformações inelásticas; todos os modelos apresentaram uma ruptura frágil da solda do enrijecedor e da chapa de topo e, em seguida, a ruptura ocorreu na solda da mesa da viga. Por sua vez na ligação mista, a laje de concreto desempenhou um papel importante na proteção das soldas da mesa superior da viga em relação à ligação metálica. O esquema proposto por Lu et al. (2017) de ligação viga-pilar utilizando chapa de topo soldada para transferir o momento para o pilar de seção I no eixo de menor inércia não foi muito eficaz.

Figura 2.15 - Ligação soldada com chapa de topo e enrijecedores.

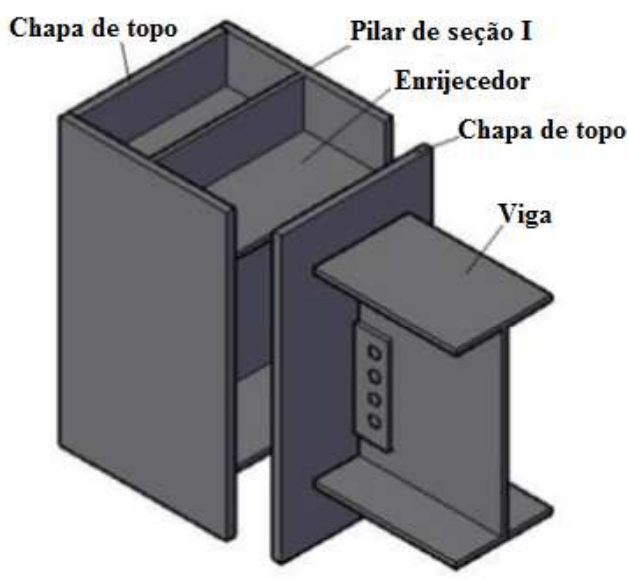

Fonte: Lu et al. (2017).

\subsubsection{Ligações Viga-Pilar com Pilar Misto Revestido de Concreto}

Chou e Uang (2002) investigaram dois modelos um com pilar de aço enrijecido e outro com pilar misto revestido com concreto, e vigas de aço para avaliar o desempenho sísmico do detalhe da ligação mostrado na Figura 2.16. Para facilitar a construção, uma quantidade reduzida de estribos em relação ao recomendado em situações sísmicas foi utilizada na região de ligação. A redução da seção da viga foi introduzida para reduzir a demanda de cisalhamento na ligação. Além disso, duas chapas enrijecedoras foram colocadas paralelas à alma do pilar para aumentar a capacidade resistente ao cisalhamento da ligação. Este estudo mostrou que: (1) a exigência rigorosa para a quantidade de estribo poderia ser amenizada; (2) as chapas enrijecedoras foram capazes de resistir a uma quantidade significativa de cisalhamento da ligação. As almas das vigas de aço ligadas ao pilar misto também contribuíram para a 
capacidade resistente ao cisalhamento. A alma do pilar de aço e as chapas enrijecedoras foram eficazes em resistir pelo menos $50 \%$ da tensão de cisalhamento na ligação. Observou-se que não há necessidade na região de ligação de $38 \%$ do estribo previsto por normas.

Figura 2.16 - Ligação proposta para ligação viga-pilar revestido.
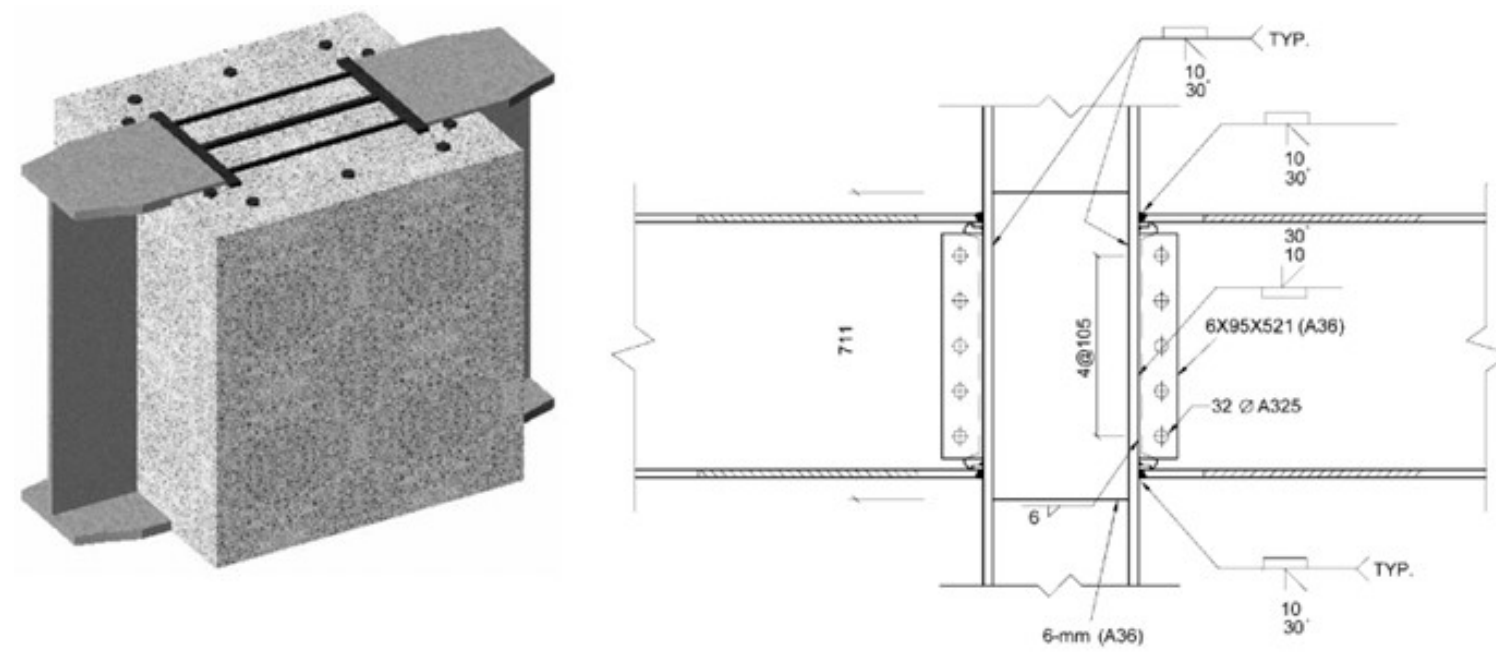

Fonte: Chou e Uang (2002).

Liew et al. (2004) ensaiaram oito espécimes cruciformes de ligação viga-pilar com laje e com reversão de cargas de forma que um lado da ligação viga-pilar estava sob momento negativo e do outro lado sob momento positivo. As ligações viga-pilar foram feitas com chapa de topo parafusada com ou sem chapa de topo estendida (Figura 2.17). Os pilares eram de aço, enrijecidos na alma com chapa soldada a esta ao longo da altura ou revestidos parcialmente com concreto. As relações momento-rotação para as ligações foram obtidas.

A carga máxima em cada ciclo (três ciclos em cada nível de deformação prédeterminado) foi comparada e verificou-se que os valores dos segundo e terceiro ciclos não foram inferiores a 95\% do primeiro ciclo. Em outras palavras, a perda de força foi inferior a $5 \%$. As curvas seguiam mais ou menos o mesmo caminho de carga/descarga durante a história de carregamento cíclico (exceto no último ciclo). Isto indicou que a rigidez da ligação vigapilar não é afetada significativamente pelos três ciclos de carga.

A chapa enrijecedora soldada na alma do pilar contribuiu significativamente para a capacidade resistente ao cisalhamento e, assim, aumentou a rigidez da ligação mista viga-pilar, a capacidade de momento negativo e a resistência à compressão da alma do pilar, mas não contribuiu da mesma forma com a capacidade de momento positivo. Já o revestimento da alma com concreto também melhorou a rigidez à rotação da ligação viga-pilar sob momento positivo e negativo. $\mathrm{O}$ concreto na alma do pilar funcionou ligeiramente melhor do que a chapa 
enrijecedora de alma na região de momento negativo, mas o efeito é o mesmo na região de momento positiva.

Figura 2.17 - Variações da ligação com chapa de topo.
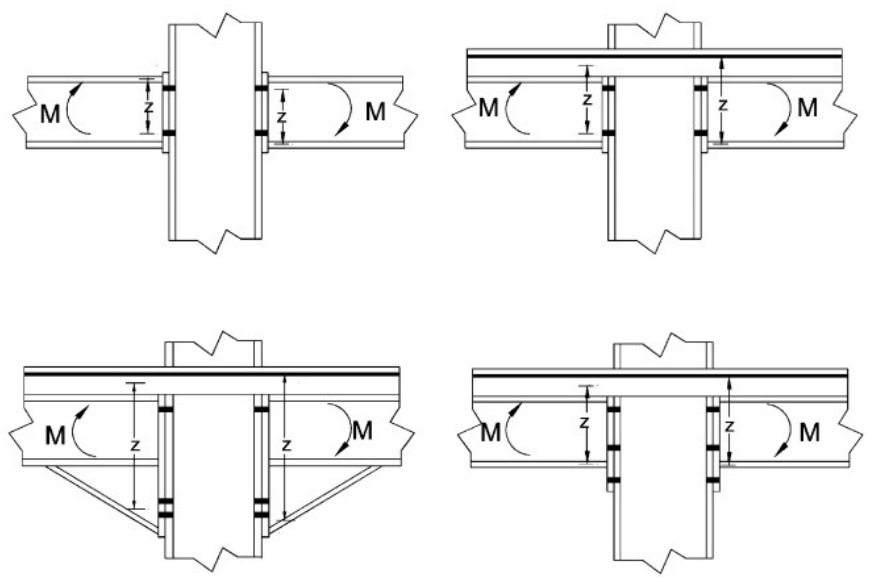

Fonte: Liew et al. (2004).

Estruturas modernas podem atingir bom desempenho sob cargas sísmicas através de um sistema dúctil que oferece mecanismos de dissipação de energia elevado sem perda de resistência. Salvatore et al. (2005) investigaram o desempenho sísmico de ligações viga-pilar de resistência parcial com laje mista e pilar parcialmente revestido de concreto, tendo em vista a construção de estruturas resistentes ao momento com alta ductilidade, onde ocorrem fenômenos inelásticos na região da alma do pilar e ligações viga-pilar (Figura 2.18). Sucessivamente, modelos em elementos finitos tridimensionais de ligação viga-pilar sujeita a força horizontal foram apresentados. Com base em considerações de ordem construtiva e comportamento sísmico favorável da alma do pilar, a solução adotada é ligação metálica somente nos perfis, o concreto é interrompido na ligação. A ligação proposta demonstrou desempenho satisfatório em termos de resistência e ductilidade. As análises paramétricas realizadas revelaram que a consideração do contato direto da laje mista com o pilar e com o concreto de revestimento causa o enrijecimento das ligações viga-pilar. 
Figura 2.18 - Ligação viga-pilar com o concreto interrompido.

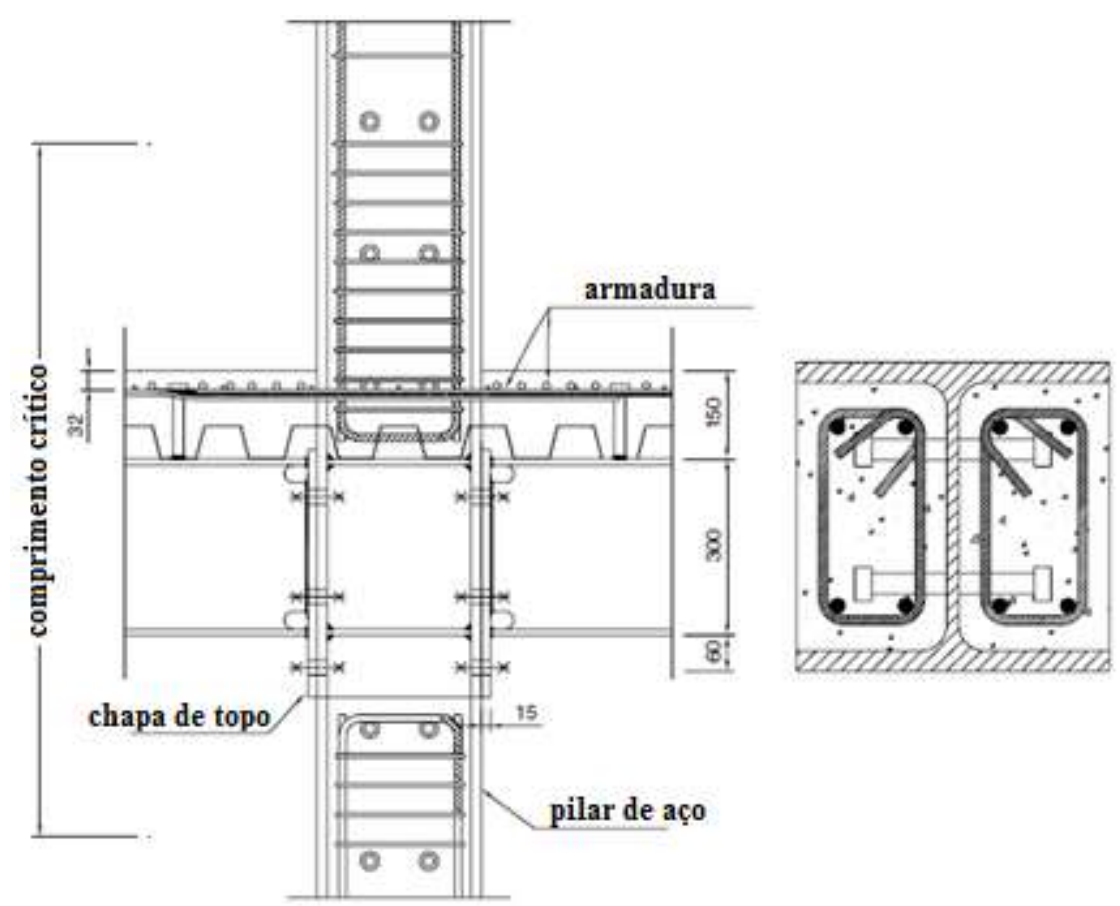

Fonte: Salvatore et al. (2005).

É claramente importante que o projeto estrutural deva evitar a ruptura das ligações, o que poderia potencialmente causar um colapso global. Uma maneira eficaz de prevenir a ruptura da ligação é aumentar sua ductilidade ao invés de sua resistência. Huang et al. (2013) relataram uma série de ensaios em altas temperaturas de ligações viga-pilar com vigas de aço, pilares de aço de seção H e pilares mistos parcialmente revestidos de concreto. Para os tipos de pilares foram estudadas as ligações viga-pilar com perfil U bem como com chapa de extremidade, com o objetivo de investigar o comportamento dessas ligações em situação de incêndio, em diferentes temperaturas, como mostra a Figura 2.19. A resistência da ligação viga-pilar reduziuse rapidamente com o aumento da temperatura. Verificou-se que as ligações com perfil U proporcionam não só alta capacidade resistente, mas também alta ductilidade que é necessária para reduzir a possibilidade de ruptura da ligação. A ductilidade da ligação com perfil U era em torno de três vezes maior que a capacidade de rotação da chapa de extremidade, com resistência final comparável e sob mesma temperatura. Notou-se também que o uso de grandes espessuras na chapa de extremidade aumenta a resistência, mas reduz significativamente a ductilidade, e devido a essa espessura, a ruptura ocorria no parafuso ou espanava a rosca, o que era evitada com porcas duplas. 
Figura 2.19 - Detalhe estudado de ligação viga-pilar parcialmente revestido em situação de incêndio.
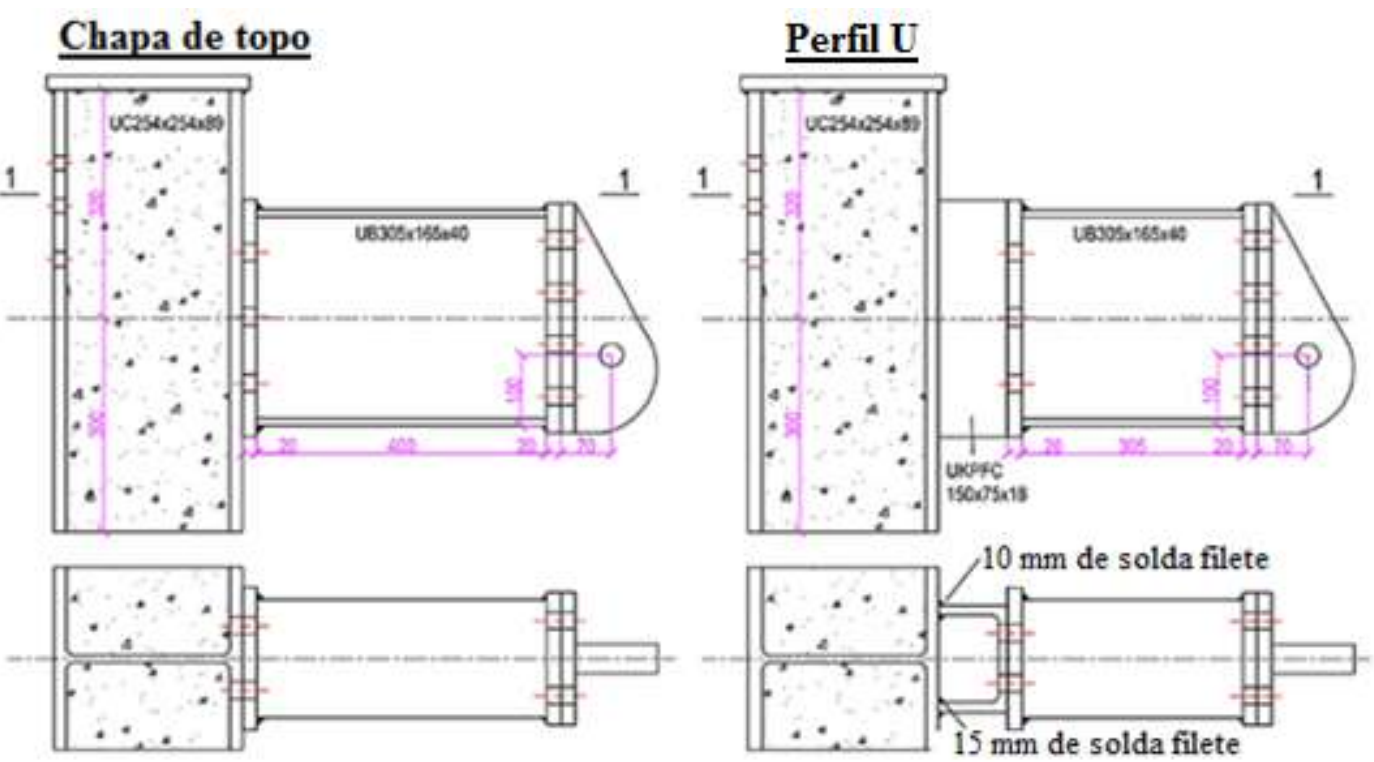

Fonte: Huang et al. (2013).

O pilar parcialmente revestido com concreto tem alta capacidade resistente, bom desempenho sísmico e vantagens econômicas. Zhao et al. (2013) estudaram o comportamento sísmico de pilares mistos parcialmente revestidos e vigas de aço através de quatro diferentes ligações viga-pilar (Figura 2.20). Ao aplicar um baixo ciclo de carregamento, os modos de falha e a distribuição de tensão em cada componente da ligação foram analisados, assim como o efeito da espessura da chapa de topo, do enrijecedor e da contraplaca (paralela à mesa do pilar) sobre a capacidade resistente, rigidez e ductilidade. A capacidade resistente eleva quando a espessura da chapa de topo é aumentada e eleva significativamente com a consideração da contraplaca, mas a ductilidade diminuiu, e estes são os dois principais fatores que afetam a degradação da rigidez da ligação em relação ao enrijecedor. Além disso, os tempos de ciclo têm pouco impacto na capacidade resistente.

Zeng et al. (2015) mostraram uma aplicação de concreto de alta resistência em estruturas mistas revestidas de concreto sob compressão axial constante do pilar e cargas cíclicas reversas, enfatizando o comportamento das ligações para o projeto sísmico. Cinco ensaios de ligações viga-pilar foram realizados, abordando duas variáveis na pesquisa: a resistência do concreto entre 80 e $110 \mathrm{MPa}$ e carga axial em serviço e última do pilar. O aumento da resistência do concreto aumentou a resistência da ligação, porém teve pouca influência na rigidez e ductilidade do sistema. A carga axial do pilar contribuiu para a resistência da ligação viga-pilar, melhorando 
a mobilização da parte externa da ligação, mas teve pouco efeito sobre a ductilidade e a capacidade de dissipação de energia, que podem ser melhoradas com armadura transversal suficiente para assegurar um bom confinamento e estabilidade das armaduras longitudinais. Isto reforça que a carga axial do pilar não pode ser negligenciada no projeto.

Figura 2.20 - Ligação viga-pilar parcialmente revestido no eixo de maior momento de inércia.
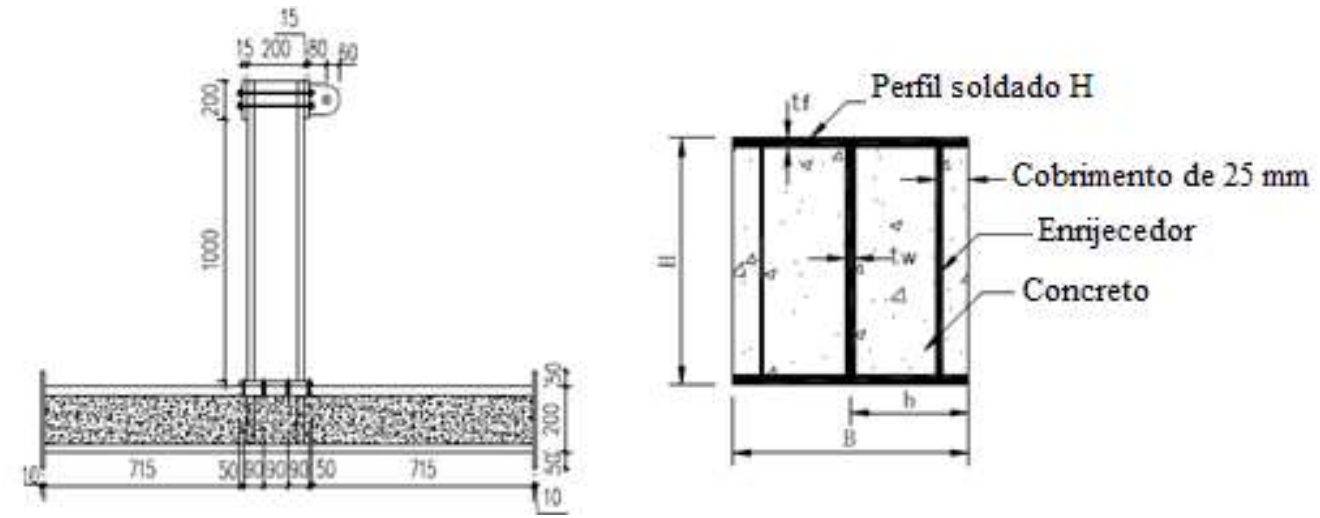

Fonte: Zhao et al. (2013).

Wang et al. (2016) propuseram uma estrutura inovadora composta de vigas de aço revestidas de concreto e pilar tubular de aço revestido com concreto. Dois modelos de pórticos foram ensaiados sob carga cíclica lateral (Figura 2.21). Não havia carregamento vertical imposto no topo dos pilares e a taxa de compressão axial do pilar era muito pequena, e isso resultou em perfeita dissipação de energia e boa ductilidade para os dois modelos. Logo, foram observados padrões de bom desempenho sísmico, tais como degradação de rigidez e dissipação de energia.

Figura 2.21 - Ligação viga-pilar tubular revestido.

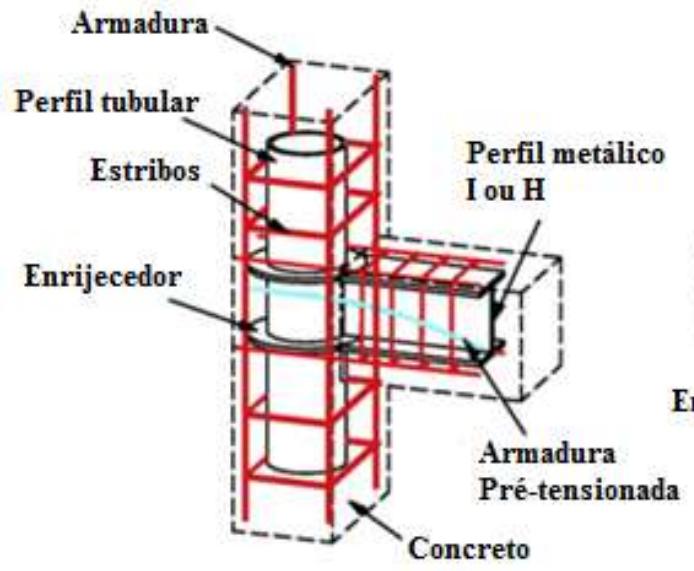

Ligacão Externa

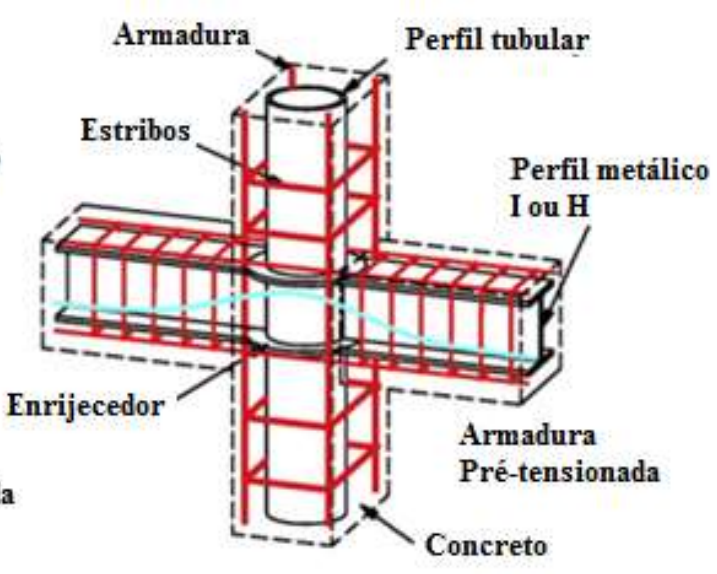

Ligação Interna

Fonte: Wang et al. (2016). 
A revisão bibliográfica permitiu verificar quais são os aspectos mais relevantes no comportamento dos pilares mistos parcialmente revestidos em ligações viga-pilar. Além disso, foi possível mapear quais os aspectos e parâmetros que vem sendo privilegiados em diferentes épocas e lugares. Percebeu-se que os pilares mistos são muito utilizados em regiões sísmicas devido à sua maior capacidade resistente em comparação com os pilares de aço. Muitos parâmetros que influenciam a rigidez e a resistência de ligações mistas foram analisados ao longo dos anos por diversos pesquisadores. Com base nos estudos, algumas conclusões prévias puderam ser estabelecidas como, por exemplo, a respeito da espessura da chapa de topo em relação ao diâmetro do parafuso para uma ligação com maior ductilidade e de chapas enrijecedoras soldadas no pilar que aumentavam a capacidade resistente da ligação. Outra variável analisada foi a altura da viga de aço, pois sua variação influencia os valores de momento resistente e de rigidez rotacional, já que o aumento da altura da viga gera um aumento do braço de alavanca. A consideração da ligação mista foi outro ponto bastante analisado com conclusões semelhantes que a laje contribui no aumento da rigidez das ligações e o grau de interação laje-viga influencia o comportamento da ligação. Em síntese, o estudo dos pilares parcialmente revestidos em ligações viga-pilar é escasso e ainda há aspectos construtivos e estruturais que não estão totalmente elucidados ou explorados, necessitando-se estudos complementares. 


\section{MODELO TEÓRICO}

\subsection{Dimensionamento de Ligação Viga-pilar segundo EC3 Parte 1-8}

Segundo Romano (2001), o método dos componentes apresentado pelo Eurocode 3 Parte 1-8 permite analisar a resistência e o comportamento mecânico de uma ligação através da sua divisão em elementos básicos. Com origem nos estudos de Zoetemeijer (1974) que propôs um modelo de escoras e tirantes para determinar a trajetória das forças de tração na ligação, esse procedimento baseia-se na distribuição plástica das forças de tração nas linhas de parafusos. Assim, as linhas em regiões próximas às mesas de vigas ou a enrijecedores, ou ainda as mais afastadas, resistem a maiores parcelas de força de tração. O método adota a hipótese que a resposta da ligação é determinada pelas propriedades mecânicas dos seus componentes, considerando-a não como um todo, mas como uma série de elementos distribuídos em 3 regiões distintas: zona tracionada, zona comprimida e zona de cisalhamento (Figura 3.1).

Figura 3.1 - Divisão das regiões a serem verificadas na ligação.

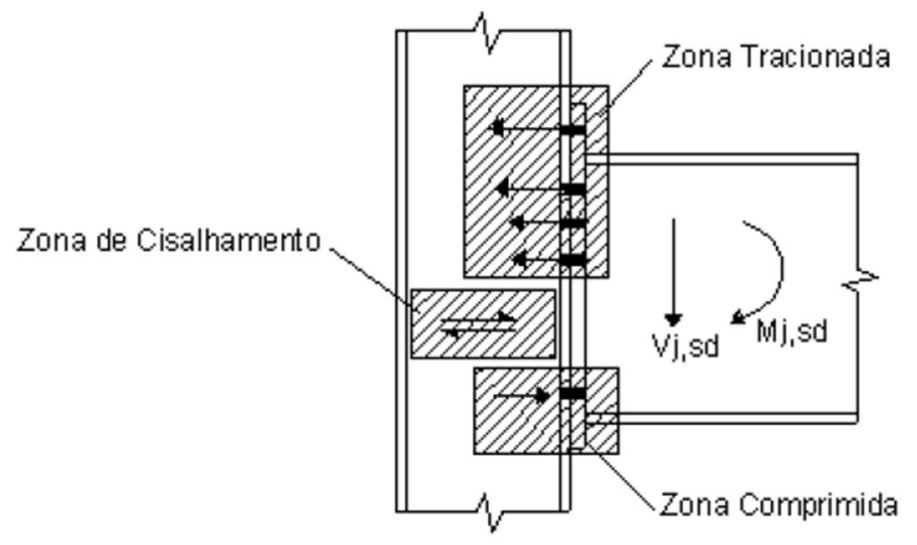

Fonte: Romano (2001).

As resistências da zona tracionada, comprimida e de cisalhamento devem ser calculadas para estabelecer o equilíbrio horizontal das forças. Na região tracionada, a resistência à tração de cada linha de parafusos é determinada pela resistência à flexão da chapa de topo, da mesa do pilar e pela resistência à tração da alma do pilar e da viga. Na região comprimida, a determinação da sua resistência é limitada por 2 possíveis modos de ruptura: flambagem da alma do pilar e esmagamento da mesa e alma da viga. Além disso, é de grande importância a determinação da resistência ao cisalhamento do painel da alma do pilar. Definidas as forças em cada linha de parafusos, determina-se o momento resistente pelo somatório do produto das forças em cada linha por sua respectiva distância do centro de rotação (ROMANO, 2001). Na 
Tabela 3.1 são apresentadas, de forma resumida, as verificações que devem ser consideradas na ligação com chapa de topo para determinação da rigidez inicial, momento resistente e resistência ao esforço cortante (as verificações 6 e 9 não citadas são para outro tipo de ligação):

Tabela 3.1 - Verificações de resistência nos elementos de ligação.

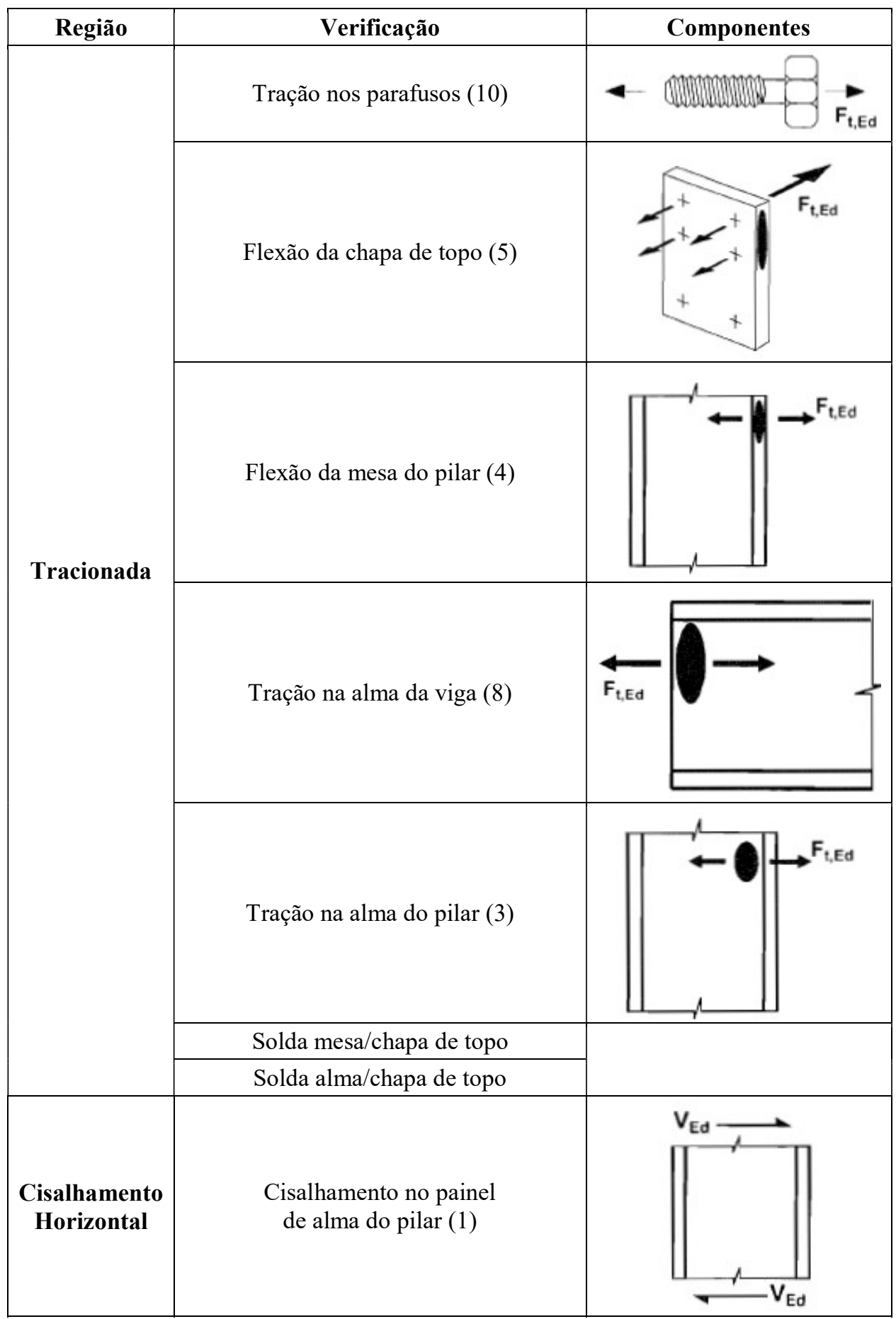




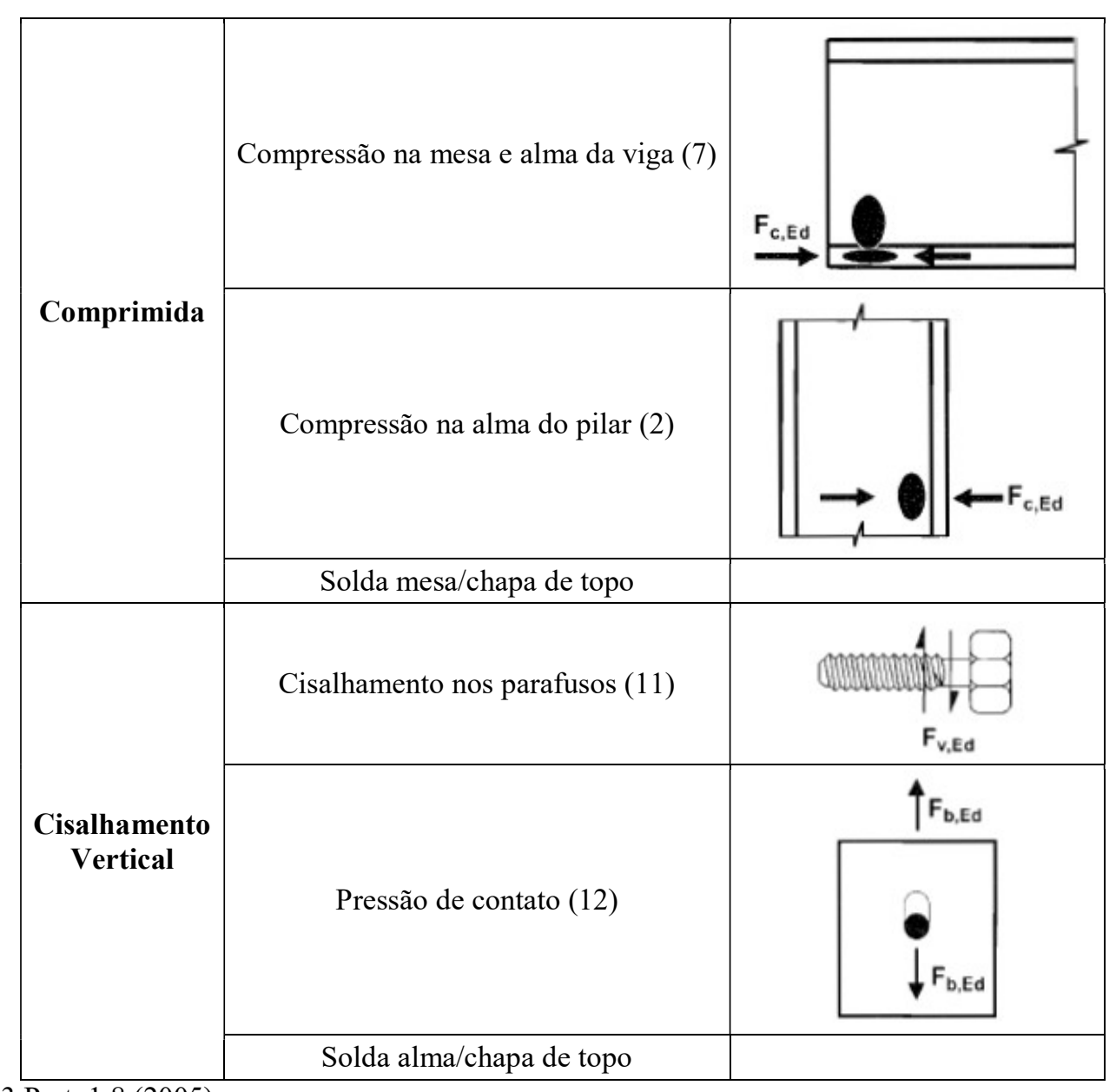

Fonte: EC3 Part. 1.8 (2005).

Este método possibilita que o comportamento estrutural de uma ligação seja caracterizado através de uma curva não linear de momento-rotação, a partir da qual se definem as três propriedades fundamentais: o momento resistente $\mathrm{M}_{\mathrm{j}, \mathrm{Rd}}$, a rigidez rotacional $\mathrm{S}_{\mathrm{j}, \text { ini }}$ e a capacidade de rotação, $\varnothing_{\text {Cd. }}$ Para a obtenção da curva (Figura 3.2), é necessário identificar as componentes relevantes, caracterizar o comportamento de cada uma delas e associar a curva força-deformação de cada componente por meio de um modelo mecânico representativo para obter a curva momento-rotação da ligação. A componente mais frágil limita a resistência da ligação. 
Figura 3.2 - Curva momento-rotação de uma ligação com chapa de topo.

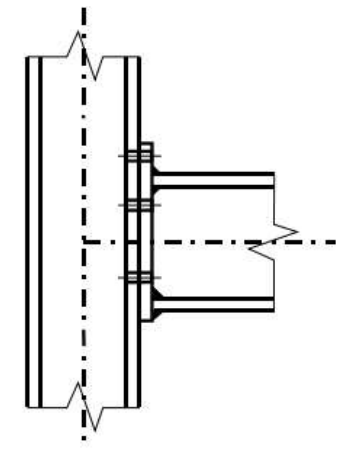

a) Ligação

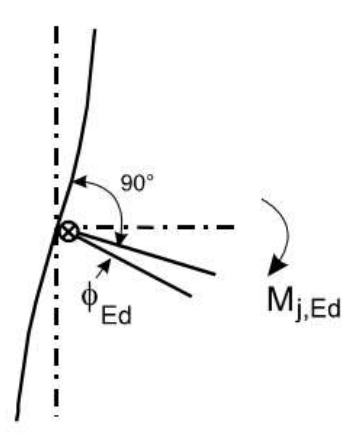

b) Modelo

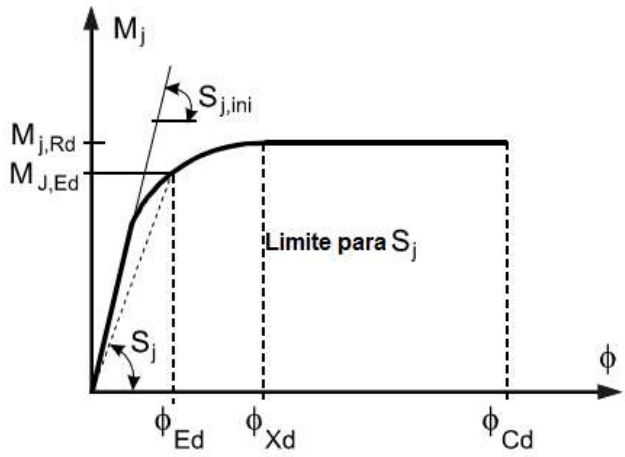

c) Curva momento-rotação carcaterística

Fonte: EC3 Part. 1.8 (2005).

A curva momento-rotação é determinada pela combinação do comportamento individual dos elementos através de modelos mecânicos compostos por barras rígidas e molas deformáveis axialmente, dispostas em paralelo ou série. Cada mola corresponde a uma componente ativa da ligação e a relação força-deformação adotada para ela pode ter origem analítica, numérica ou experimental. Como o presente trabalho aborda as ligações viga-pilar com chapa de topo, na Figura 3.3 mostra-se a aplicação do método das componentes para esse tipo de ligação.

Figura 3.3 - Método das componentes para ligação com chapa de topo.
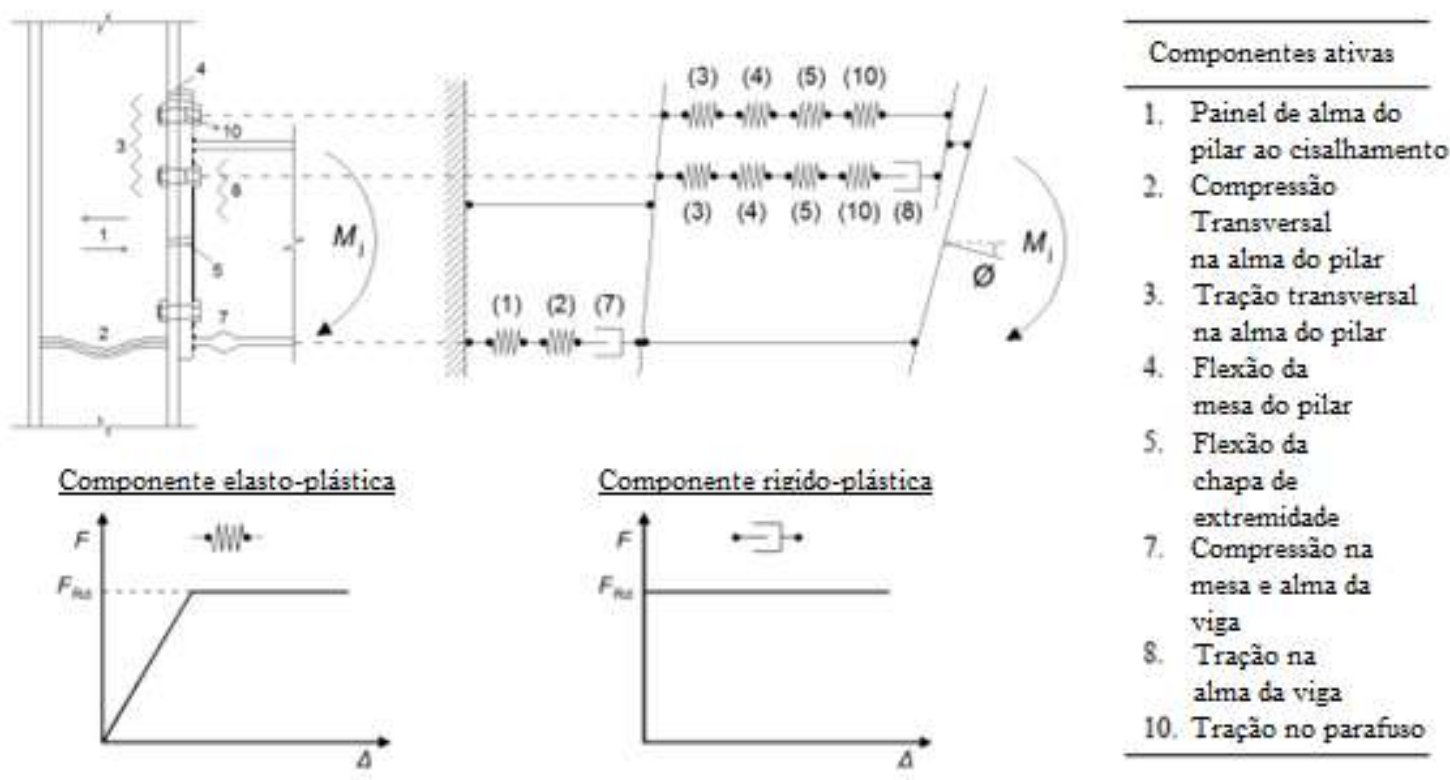

Fonte: Vieito (2015). 


\section{4 | MODELO TEÓRICO}

Ao longo deste capítulo pretende-se resumir alguns pontos que se consideram importantes para a determinação da resistência de cálculo dos componentes básicos, destacando-se as componentes relativas às ligações com chapa de topo e parafusos.

\subsubsection{Cisalhamento do painel da alma do pilar (componente 1)}

O dimensionamento desta componente está descrito no item 6.2.6.1 do EC3 Parte 1-8 (2005) e só é válido quando a esbelteza da alma do pilar respeitar a seguinte condição (Equação 3.1), caso contrário, ou se altera o perfil ou não se pode usar esse método:

$$
\frac{d_{c}}{t_{w c}} \leq 69 \varepsilon \text { em que } \varepsilon=\sqrt{235 / f_{y, w c}}
$$

Onde $d_{c}$ é a distância entre as mesas do pilar, excluindo os raios de concordância.

De acordo com o item 6.2.6.1 do EC3, para uma ligação viga-pilar com pilar de extremidade ou com vigas dos dois lados, mas com alturas semelhantes, a resistência ao cisalhamento de cálculo $\left(\mathrm{V}_{\mathrm{wp}, \mathrm{Rd}}\right)$ do painel da alma do pilar não enrijecido (sem enrijecedores transversais) é dada pela seguinte Equação 3.2, na qual o fator de redução 0,9 considera a tensão longitudinal de compressão no pilar:

$$
V_{w p, R d}=\frac{0,9 f_{y, w c} A_{v c}}{\sqrt{3} \gamma_{M 0}}
$$

Em que $A_{v c}$ é a área cisalhante do pilar, fy,wc é a tensão de escoamento da alma do pilar, $\gamma_{\mathrm{M} 0}$ é o coeficiente de segurança ao escoamento da seção $=1$. Para perfis laminados I ou H, temos que a área cisalhante do pilar é dada pela Equação 3.3:

$$
A_{v c}=A_{c}-2 b_{c} t_{f c}+\left(t_{w c}+2 r_{c}\right) t_{f c}
$$

Onde $\mathrm{A}_{\mathrm{c}}$ é a área da seção transversal do pilar, $\mathrm{t}_{\mathrm{fc}}$ é a espessura da mesa do pilar, $\mathrm{t}_{\mathrm{wc}}$ é a espessura da alma do pilar, $\mathrm{r}_{\mathrm{c}}$ é o raio de concordância do pilar e $\mathrm{b}_{\mathrm{c}}$ é a largura da mesa do pilar.

Quando o painel de alma do pilar não possui resistência ou rigidez suficiente para resistir aos esforços atuantes, pode-se aumentar a sua resistência por meio de enrijecedores transversais, chapas de alma adicionais ou os dois juntos. Caso sejam adicionados enrijecedores transversais ao pilar nas zonas de compressão e de tração, deve ser adicionado o valor de $\mathrm{V}_{\text {wp,add,Rd }}$ (Equação 3.4) à resistência ao cisalhamento do painel de alma do pilar.

$$
V_{w p, a d d, R d}=\frac{4 M_{p l, f c, R d}}{d_{s}} \text { mas } V_{w p, a d d, R d} \leq \frac{2 M_{p l, f c, R d}+2 M_{p l, s t, R d}}{d_{s}}
$$

Onde $\mathrm{d}_{\mathrm{s}}$ é à distância entre as linhas de centro dos enrijecedores; $\mathrm{M}_{\mathrm{pl}, \mathrm{fc}, \mathrm{Rd}}$ é o momento resistente plástico da mesa do pilar em relação ao menor eixo de inércia $\left(Z . f_{\mathrm{y}}\right) ; \mathrm{M}_{\mathrm{pl}, \mathrm{st} \text {,Rd }}$ é o momento resistente plástico do enrijecedor transversal em relação ao maior eixo de inércia 
(Z.fy). O momento resistente plástico, tanto da mesa do pilar como do enrijecedor transversal é dado pelo módulo plástico de flexão de cada elemento multiplicado pela tensão de escoamento. O módulo plástico de flexão é dado pela Equação 3.5:

$$
M_{p l, f c, R d}=M_{p l, s t, R d}=W_{p l} f_{y}=\frac{b t^{2}}{4} f_{y}
$$

Em que b é a largura da mesa do pilar ou do enrijecedor transversal; t é a espessura da mesa do pilar ou do enrijecedor transversal.

Caso se pretenda reforçar a alma do pilar com a adição de uma ou duas chapas de alma adicionais, estas aumentam a resistência $V_{\mathrm{wp}, \mathrm{Rd}}$ com o aumento da área cisalhante do pilar, $A_{\mathrm{vc}}$.

$\mathrm{O}$ valor do coeficiente de rigidez do cisalhamento do painel da alma do pilar $\left(\mathrm{k}_{1}\right)$ é obtido pela Equação 3.6 a seguir, mas se a alma do pilar for reforçada, o valor do coeficiente de rigidez é infinito.

$$
k_{1}=\frac{0,38 A_{v c}}{\beta z}
$$

Em que z é o valor do braço de alavanca calculado conforme a Tabela 3.8.

\subsubsection{Flambagem da alma do pilar por compressão transversal (componente 2)}

A alma do pilar está solicitada a forças horizontais concentradas que são transmitidas a partir da chapa de topo, da mesa do pilar e da mesa comprimida da viga. Assim, os esforços originam tensões de compressão na alma do pilar, provocadas por um momento fletor negativo na viga. O dimensionamento desta componente encontra-se no item 6.2.6.2 do EC3 Parte 1-8. A resistência de cálculo da alma não enrijecida (sem enrijecedores transversais) sujeita à compressão transversal é determinada a partir da Equação 3.7:

$$
F_{c, w c, R d}=\frac{\omega k_{w c} b_{e f f, c, w c} t_{w c} f_{y, w c}}{\gamma_{M 0}} \text { mas } F_{c, w c, R d} \leq \frac{\omega k_{w c} \rho b_{e f f, c, w c} t_{w c} f_{y, w c}}{\gamma_{M 1}}
$$

Onde,

$\beta$ é um parâmetro de transformação obtido através da Tabela 3.2, que depende do número de ligações no pilar e a razão entre os momentos atuantes de cada lado;

$\omega$ é um coeficiente de redução que leva em conta os efeitos da interação com o cisalhamento do painel da alma de acordo com a Tabela 3.3;

$\mathrm{k}_{\mathrm{wc}}$ é um fator de redução relacionado à tensão longitudinal máxima na alma do pilar, $\sigma_{\text {com,Ed }}$ (Equação 3.8), devido à ação da força axial e do momento fletor ao mesmo tempo no pilar, apresentado pela equação: 


$$
\begin{gathered}
\text { Quando } \sigma_{c o m, E d} \leq 0,7 f_{y, w c} \rightarrow k_{w c}=1 \\
\text { Quando } \sigma_{c o m, E d}>0,7 f_{y, w c} \rightarrow k_{w c}=1,7-\frac{\sigma_{c o m, E d}}{f_{y, w c}} \\
\sigma_{c o m, E d}=\frac{N_{c, E d}}{A_{c}}+\frac{M_{c, E d}}{W_{e l, y, c}}
\end{gathered}
$$

$\mathrm{N}_{\mathrm{c} \text {,Ed }}$ é a força axial atuante no pilar;

$\mathrm{M}_{\mathrm{c}, \mathrm{Ed}}$ é o momento fletor atuante no pilar;

Tabela 3.2 - Parâmetro de transformação $\beta$.

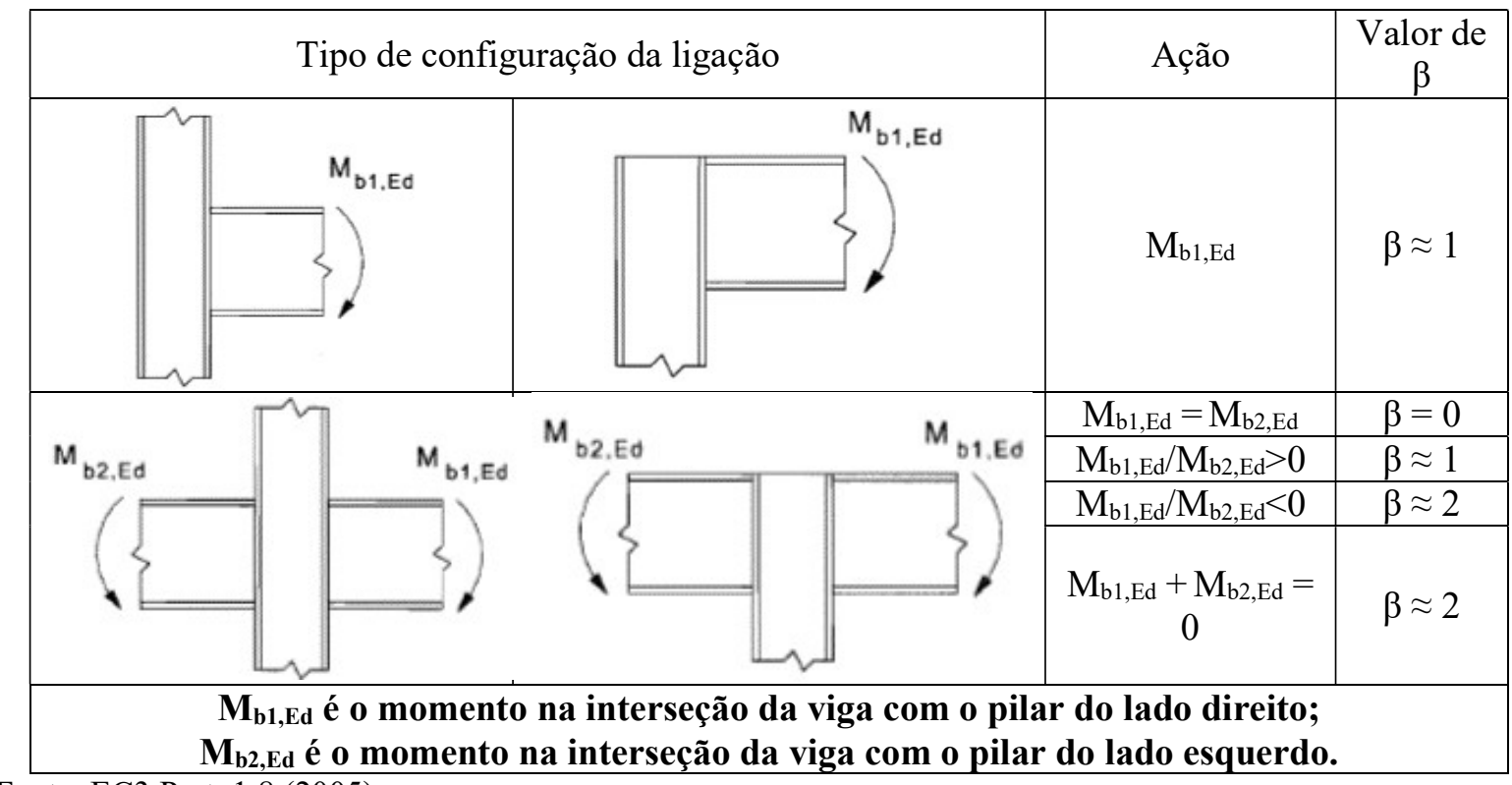

Fonte: EC3 Part. 1.8 (2005).

Tabela 3.3 - Coeficiente de redução $\omega$.

\begin{tabular}{|c|c|}
\hline Parâmetro de transformação $\beta$ & Coeficiente de redução $\omega$ \\
\hline $\mathbf{0} \leq \boldsymbol{\beta} \leq \mathbf{0 , 5}$ & $\omega=1$ \\
\hline $\mathbf{0 , 5}<\boldsymbol{\beta}<\mathbf{1}$ & $\omega=\omega_{1}+2(1-\beta)\left(1-\omega_{1}\right)$ \\
\hline $\boldsymbol{\beta}=\mathbf{1}$ & $\omega=\omega_{1}$ \\
\hline $\boldsymbol{1}<\boldsymbol{\beta}<\mathbf{2}$ & $\omega=\omega_{1}+(\beta-1)\left(\omega_{2}-\omega_{1}\right)$ \\
\hline $\boldsymbol{\beta}=\mathbf{2}$ & $\omega_{2}=\frac{1}{\sqrt{1-5,2\left(b_{e f f, c, w c} t_{w c} / A_{v c}\right)^{2}}}$ \\
\hline
\end{tabular}

Fonte: EC3 Part. 1.8 (2005).

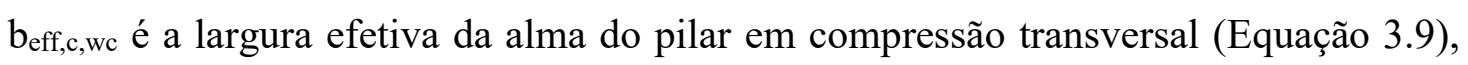
para ligações com chapa de topo:

$$
b_{e f f, c, w c}=t_{f b}+2 \sqrt{2} a_{p}+5\left(t_{f c}+s\right)+s_{p}
$$

$\mathrm{t}_{\mathrm{fb}}$ é a espessura da mesa comprimida da viga;

$a_{p}$ é o cordão de solda que liga a chapa de topo com a mesa da viga (Figura 3.4); 
$t_{\mathrm{fc}}$ é a espessura da mesa do pilar;

$\mathrm{s}$ é igual a $\mathrm{r}_{\mathrm{c}}$ para pilares de seção laminada;

$\mathrm{S}_{\mathrm{p}}$ é o comprimento obtido pela dispersão em $45^{\circ}$ através da chapa de topo ( $\mathrm{t}_{\mathrm{p}}$ até $2 \mathrm{t}_{\mathrm{p}}$ );

$t_{p}$ é a espessura da chapa de topo;

$\rho$ é o fator de redução devido à flambagem da chapa e pode ser calculado a partir do coeficiente de esbeltez $\left(\lambda_{\mathrm{p}}\right)$ nas seguintes condições:

$$
\begin{gathered}
\text { Se } \lambda_{p} \leq 0,72: \rho=1,0 \\
\text { Se } \lambda_{p}>0,72: \rho=\frac{\lambda_{p}-0,2}{\lambda_{p}{ }^{2}}
\end{gathered}
$$

Onde $\lambda_{\mathrm{p}}$ pode ser determinado a partir da Equação 3.10:

$$
\lambda_{p}=0,932 \sqrt{\frac{b_{e f f, c, w c} d_{w c} f_{y, w c}}{E t_{w c}^{2}}}
$$

O valor da altura da alma da coluna $\left(\mathrm{d}_{\mathrm{wc}}\right)$ é determinado pela equação para pilares em perfil laminado em I ou H: $d_{w c}=h_{c}-2\left(t_{f c}+r_{c}\right)$.

Figura 3.4 - Parâmetros a ser considerados na ligação com chapa de topo e perfil laminado.
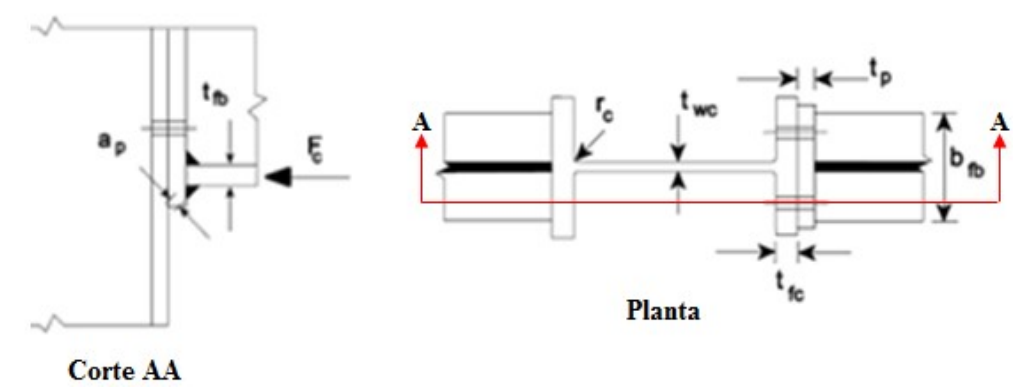

Fonte: EC3 Part. 1.8 (2005).

Da mesma forma, a alma do pilar sujeita a compressão transversal também pode ser reforçada quando não tem resistência ou rigidez suficiente para resistir aos esforços solicitantes. Com a adição de chapas de alma no pilar, a espessura da alma aumenta e isso introduzirá variações em todas as expressões que dependem da espessura da alma $\left(t_{\mathrm{wc}} \mathrm{e} A_{\mathrm{vc}}\right)$

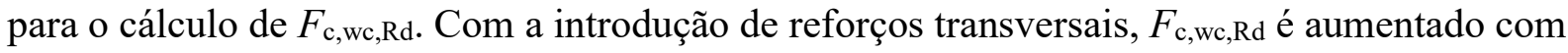

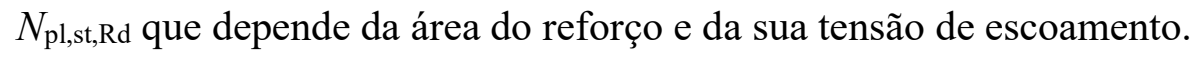

$\mathrm{O}$ valor do coeficiente de rigidez da alma do pilar à compressão $\left(\mathrm{k}_{2}\right)$ pode ser calculado pela Equação 3.11, mas se a alma do pilar for reforçada, o valor do coeficiente de rigidez é infinito. 


$$
k_{2}=\frac{0,7 b_{e f f, c, w c} t_{w c}}{d_{c}}
$$

\subsubsection{Escoamento da alma do pilar por tração transversal (componente 3)}

Semelhantemente com o que acontece na região inferior do painel de alma do pilar com tensões de compressão transversal para um momento fletor negativo, na região superior ocorre o mesmo, mas com tensões de tração transversal. Estas tensões de tração na alma do pilar desenvolvem-se na região compreendida entre as linhas de parafusos que se encontram à tração. O dimensionamento desta componente apresenta-se no item 6.2.6.3 do EC3 Parte 1-8 e a resistência da alma não enrijecida do pilar à tração transversal pode ser determinada conforme a seguinte Equação 3.12:

$$
F_{t, w c, R d}=\frac{\omega b_{e f f, t, w c} t_{w c} f_{y, w c}}{\gamma_{M 0}}
$$

Em que:

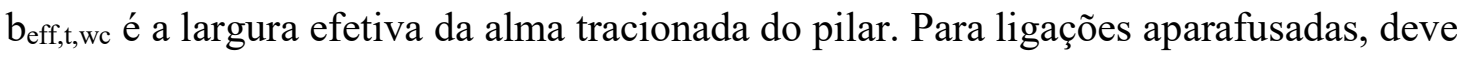

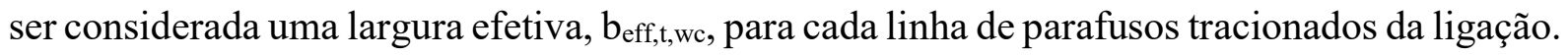

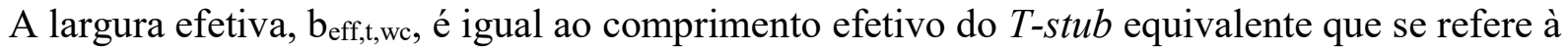
flexão da mesa pilar, sendo necessário considerar que as linhas de parafusos podem atuar isoladamente ou em grupos. Os restantes parâmetros da expressão já foram definidos.

Com a adição de chapas de alma no pilar, a espessura da alma aumenta e introduz variações em todas as expressões que dependem da espessura da alma ( $t_{\mathrm{wc}}$ e $\mathrm{A}_{\mathrm{vc}}$ ) para o cálculo

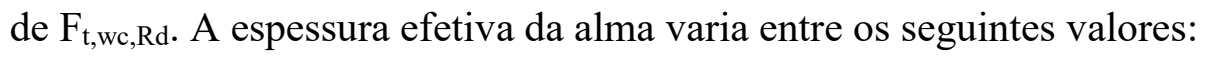

Cordão da solda longitudinal da chapa de alma com penetração total e com espessura a $\geq t_{s}$ :

Chapa de alma em apenas um lado: $t_{w, \text { eff }}=1,5 t_{w c}$

Chapas de alma em ambos os lados: $t_{w, e f f}=2 t_{w c}$

Cordão da solda longitudinal da chapa de alma com solda filete e com espessura $\mathrm{a} \geq t_{s} / \sqrt{2}:$

Para aços de classe S235, S275 e S355: $t_{w, e f f}=1,4 t_{w c}$

Para aços de classe S420 e S460: $t_{w, e f f}=1,3 t_{w c}$

$\mathrm{O}$ valor do coeficiente de rigidez da alma do pilar à tração $\left(\mathrm{k}_{3}\right)$ pode ser calculado pela Equação 3.13: 


$$
k_{3}=\frac{0,7 b_{e f f, t, w c} t_{w c}}{d_{c}}
$$

\subsubsection{Mesa do pilar em flexão transversal (componente 4)}

Para determinação da resistência e rigidez à flexão da mesa do pilar em ligações aparafusadas, o EC3 propõe a substituição da complexa configuração de charneiras plásticas ao redor do parafuso tracionado na ligação pela utilização de um modelo simplificado: T-stub equivalente (Figura 3.5). O T-stub equivalente avalia a resistência dos vários elementos que o constituem para quantificar a carga que leva ao colapso plástico de uma placa. Este modelo é usado na zona tracionada da ligação aparafusada para determinar a resistência à flexão da mesa do pilar e da chapa de topo e resistência à tração da alma do pilar e da alma da viga.

Figura 3.5 - T-stub equivalente tracionado.
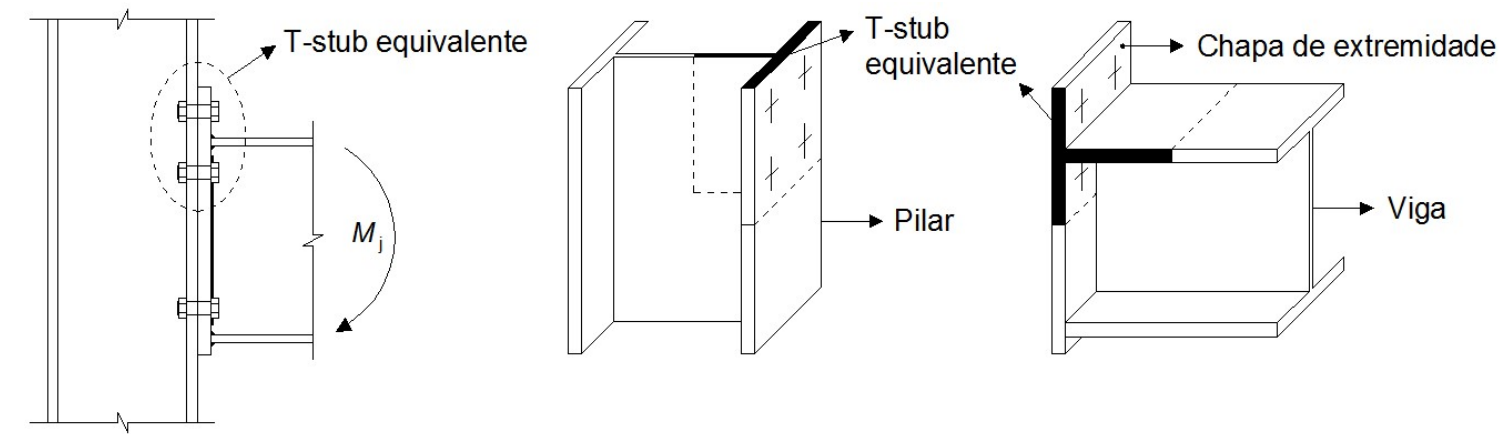

Fonte: Vieito (2015).

Para o cálculo através do modelo $T$-stub equivalente, deve-se considerar a possibilidade de que a respectiva linha de parafusos atue como uma linha isolada ou como parte de um grupo de linhas de parafusos e sua resistência será dada pelo valor mais desfavorável. Como pode se observar na Figura 3.6, na primeira situação as linhas de ruptura formam-se individualmente em cada linha de parafusos. Já na segunda situação só há algumas linhas de ruptura em grupo. E por fim, na terceira situação todas as linhas de ruptura formam-se em grupo. 
Figura 3.6 - Modelos de linhas de ruptura de parafusos atuando de forma isolada ou em grupo.
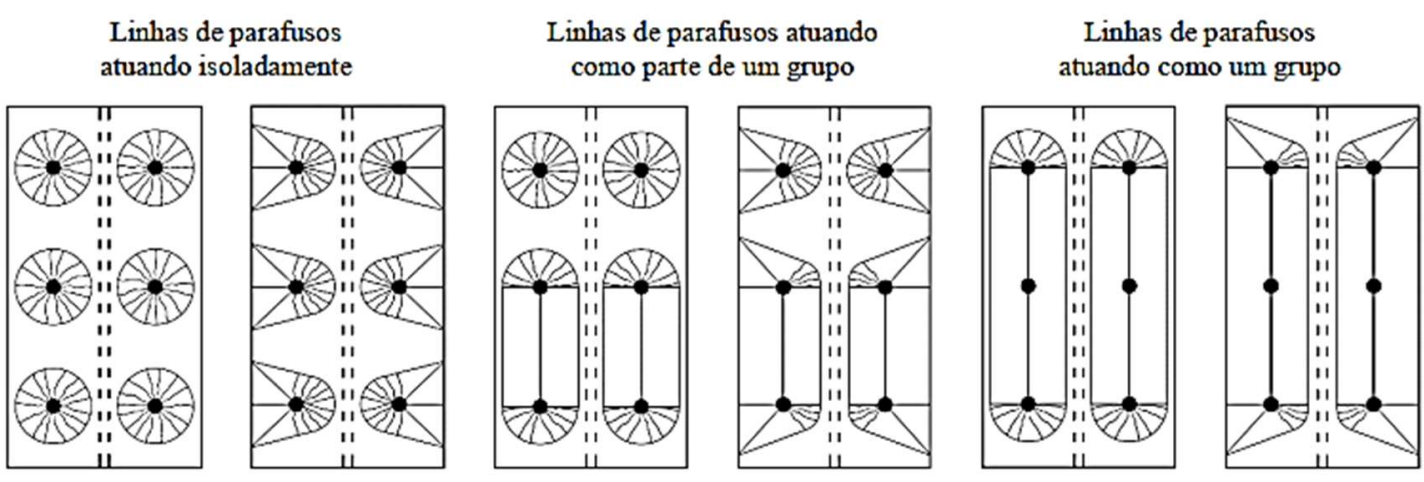

Fonte: Vieito (2015).

Tendo em vista que a contribuição de uma linha de parafusos isolada para a capacidade resistente de uma ligação à flexão é diferente da contribuição da mesma linha quando esta faz parte de um grupo de linhas de parafusos, apresenta-se um procedimento, de acordo com EC3 Part. 1.8 (2005), para determinar a capacidade resistente à tração de cada linha de parafusos nos seguintes passos, como ilustra a Figura 3.7:

1) A resistência de cada linha de parafusos é calculada individualmente, iniciando pela linha mais afastada do centro de compressão (a $1^{\text {a }}$ linha), depois a $2^{\mathrm{a}}$ linha, e assim sucessivamente;

2) A resistência da $1^{\text {a }}$ linha é calculada como uma linha de parafusos isolada e as seguintes são avaliadas como isoladas e como parte de um grupo. No caso da linha de parafuso atuando em grupo, a resistência será dada pelo menor valor obtido entre a resistência da linha de parafuso isolada e a resistência da linha de parafuso atuando como um grupo, subtraindo a capacidade resistente das linhas anteriores antes da distribuição interna de forças calculadas para a ação isolada.

3) A resistência das linhas, que são divididas por uma mesa ou por um reforço transversal, é igual a de linhas de parafusos isoladas porque estes não possibilitam a formação de um grupo entre elas;

4) A linha de parafusos que se encontra mais próxima do centro de compressão é desprezada nos cálculos como tracionada (apesar de o ser) devido à sua baixa contribuição para o momento resistente, é apenas considerada para a resistência ao cisalhamento. 
Figura 3.7 - Procedimento para determinação da resistência à tração de linha de parafusos.

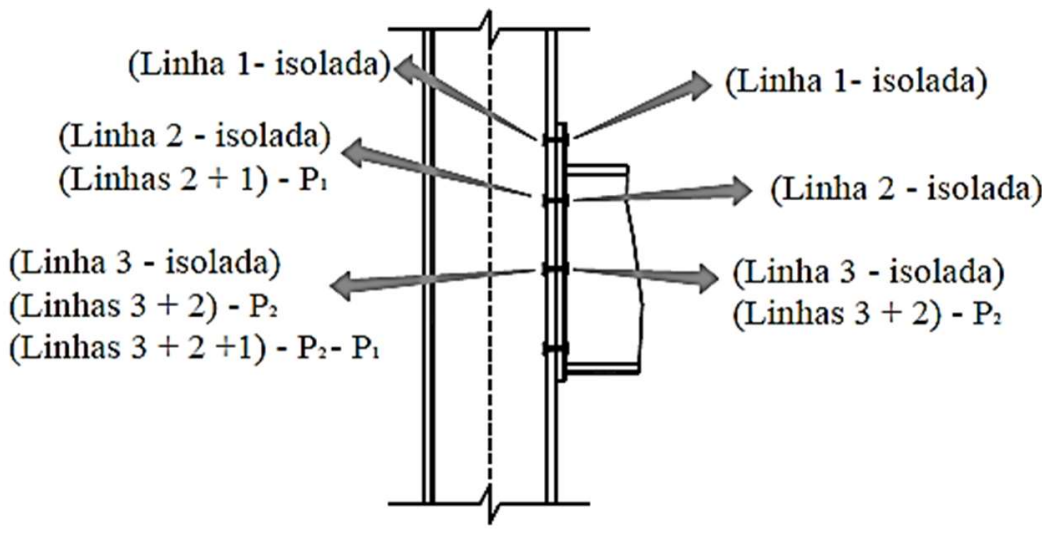

$\sqrt{\frac{0}{0}}$

Flexão da mesa do pilar

Flexão da chapa de topo

Fonte: Oliveira (2011)

A resistência de cálculo à tração, $\mathrm{F}_{\mathrm{T}, \mathrm{Rd}}$, de um T-stub é determinado de acordo com o item 6.2.4 do EC3 Parte 1-8 através dos dados geométricos $e_{\min }, \ell_{\text {eff }}$ e $m$ e pela existência de 3 modos de ruptura entre os elementos de um T-stub. Na Figura 3.8 apresenta-se os 3 modos de ruptura de um $T$-stub.

Figura 3.8 - Modos de ruptura para T-stub.

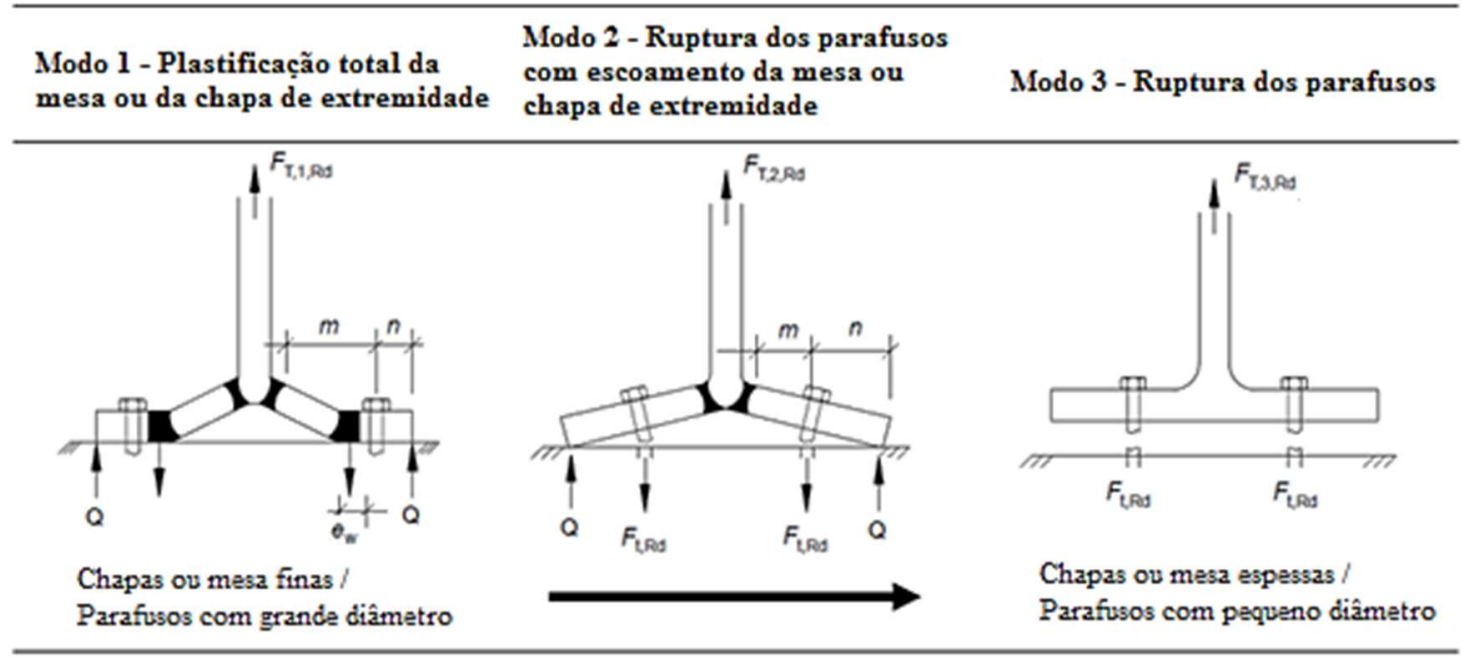

Fonte: Vieito (2015).

$1^{\circ}$ Modo de ruptura: devido à reduzida espessura da mesa, ocorre a plastificação total da mesma sem a ruptura dos parafusos. Pode-se observar que, ao se aplicar uma carga, vão se formar quatro rótulas plásticas, duas junto às linhas de parafusos, resultantes do momento fletor provocado pelas forças de alavanca, junto às linhas dos parafusos e na interseção da alma com a mesa do. Assume-se que as "forças de alavanca", Q, podem atingir o seu valor máximo. 
$2^{\circ}$ Modo de ruptura: considera simultaneamente a formação de rótulas plásticas na interseção da alma com a mesa do "T-stub" e a ruptura dos parafusos. Para este caso, as forças de alavanca podem levar à ruptura dos parafusos antes que ocorra escoamento total da mesa junto às linhas de parafusos.

$3^{\circ}$ Modo de ruptura: quando a deformabilidade da mesa é muito inferior à dos parafusos, admite-se que o colapso destes ocorre sem a formação de rótulas plásticas na mesa. Neste caso, as forças de alavanca são inexistentes ou desprezíveis.

Para que o equilíbrio de forças na mesa do "T-stub" equivalente seja mantido, a força de tração máxima atuante na alma é apresentada pela Tabela 3.4. Para o método 1 considera-se que os parafusos transmitem as forças de tração sob a forma de cargas concentradas em seus eixos e para o método dois admite-se que a força aplicada por um parafuso na mesa do "T-stub" encontra-se uniformemente distribuída pelas arruelas, porcas ou cabeça do parafuso. Os efeitos de alavanca estão implicitamente considerados quando se determina o valor de cálculo da resistência à tração.

Tabela 3.4 - Modelo de cálculo da capacidade resistente.

\begin{tabular}{|c|c|c|c|}
\hline & \multicolumn{2}{|c|}{ Ocorrência de forças de alavanca, ou seja, $L_{b} \leq L_{b}{ }^{*}$} & $\begin{array}{l}\text { Sem forças } \\
\text { de alavanca }\end{array}$ \\
\hline Modo 1 & Método 1 & Método 2 & \multirow{4}{*}{$=\frac{\begin{array}{l}\mathrm{F}_{\mathrm{T}, 1-2, \mathrm{Rd}} \\
2 \mathrm{M}_{\mathrm{pl}, 1, \mathrm{Rd}}\end{array}}{\mathrm{m}}$} \\
\hline $\begin{array}{c}\text { Sem contra } \\
\text { placa }\end{array}$ & $\mathrm{F}_{\mathrm{T}, 1, \mathrm{Rd}}=\frac{4 \mathrm{M}_{\mathrm{pl}, 1, \mathrm{Rd}}}{\mathrm{m}}$ & $\mathrm{F}_{\mathrm{T}, 1, \mathrm{Rd}}=\frac{\left(8 \mathrm{n}-2 \mathrm{e}_{\mathrm{w}}\right) \mathrm{M}_{\mathrm{pl}, 1, \mathrm{Rd}}}{2 \mathrm{mn}-\mathrm{e}_{\mathrm{w}}(\mathrm{m}+\mathrm{n})}$ & \\
\hline $\begin{array}{c}\text { Com contra } \\
\text { placa }\end{array}$ & $\mathrm{F}_{\mathrm{T}, 1, \mathrm{Rd}}=\frac{4 \mathrm{M}_{\mathrm{pl}, 1, \mathrm{Rd}}+2 \mathrm{M}_{\mathrm{bp}, \mathrm{Rd}}}{\mathrm{m}}$ & $\mathrm{F}_{\mathrm{T}, 1, \mathrm{Rd}}=\frac{\left(8 \mathrm{n}-2 \mathrm{e}_{\mathrm{w}}\right) \mathrm{M}_{\mathrm{pl}, 1, \mathrm{Rd}}+4 \mathrm{n} \mathrm{M}_{\mathrm{bp}, \mathrm{Rd}}}{2 \mathrm{mn}-\mathrm{e}_{\mathrm{w}}(\mathrm{m}+\mathrm{n})}$ & \\
\hline Modo 2 & \multicolumn{2}{|c|}{$\mathrm{F}_{\mathrm{T}, 2, \mathrm{Rd}}=\frac{2 \mathrm{M}_{\mathrm{pl}, 2, \mathrm{Rd}}+\mathrm{n} \sum \mathrm{F}_{\mathrm{t}, \mathrm{Rd}}}{\mathrm{m}+\mathrm{n}}$} & \\
\hline Modo 3 & & $\mathrm{~F}_{\mathrm{T}, 3, \mathrm{Rd}}=\sum \mathrm{F}_{\mathrm{t}, \mathrm{Rd}}$ & \\
\hline
\end{tabular}

$\mathrm{L}_{b}$ é o comprimento do parafuso sujeito a alongamento. Considera-se que este comprimento é igual ao comprimento de aperto (soma da espessura total das chapas e das arruelas) acrescentado de metade da altura da cabeça e da porca do parafuso.

$\mathrm{L}_{\mathrm{b}}^{*}=\frac{8,8 \mathrm{~m}^{3} \mathrm{~A}_{\mathrm{s}} \mathrm{n}_{\mathrm{b}}}{\sum \mathrm{l}_{\mathrm{eff}, \mathrm{1}} \mathrm{t}_{\mathrm{f}}^{3}}$

$\mathrm{n}_{\mathrm{b}}$ é o número de linhas de parafusos;

$\mathrm{F}_{\mathrm{T}, \mathrm{Rd}}$ é capacidade resistente à tração da mesa do " $T$-sub";

Q é a força de alavanca; 


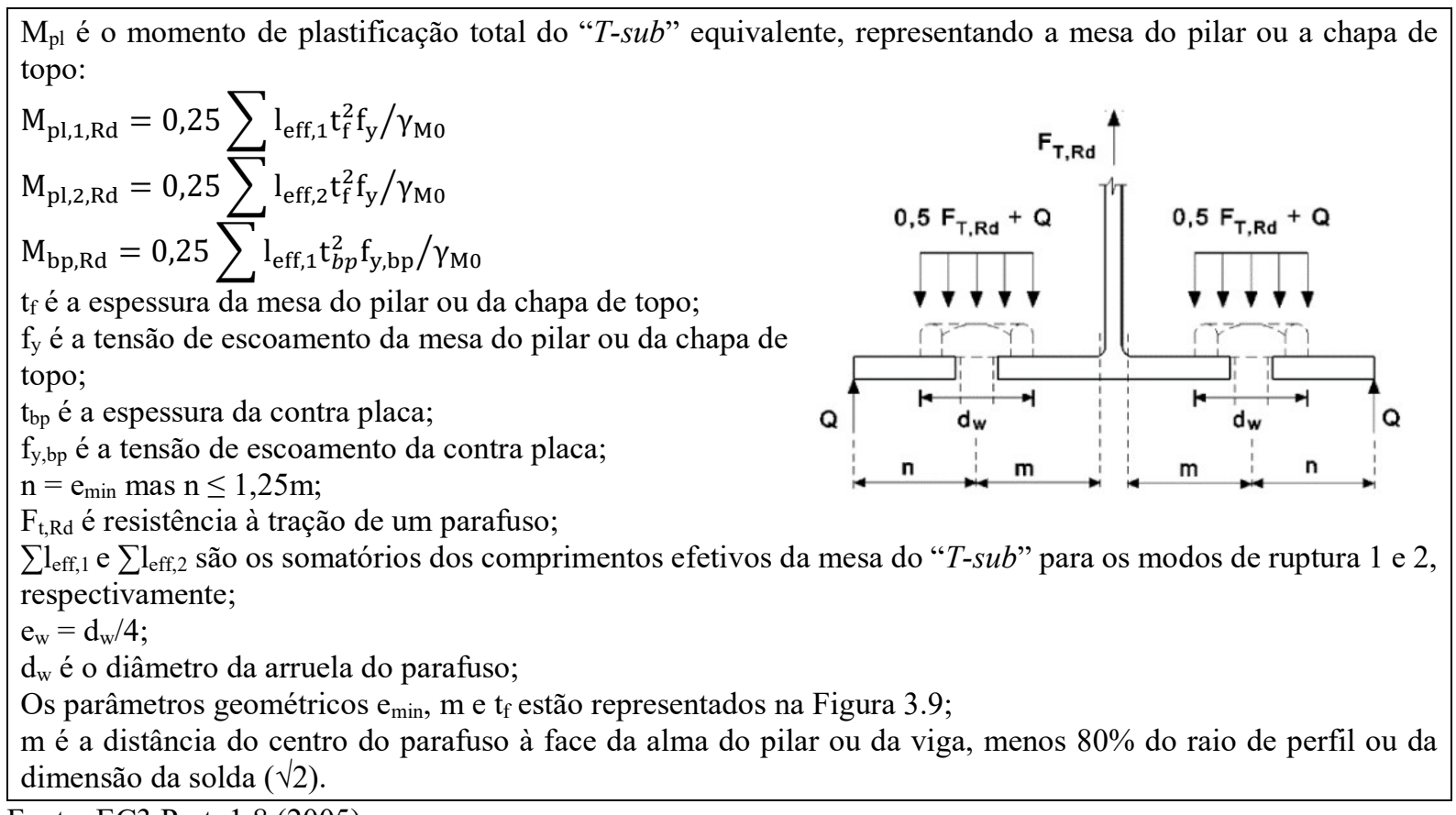

Figura 3.9 - Parâmetros geométricos do T-stub.
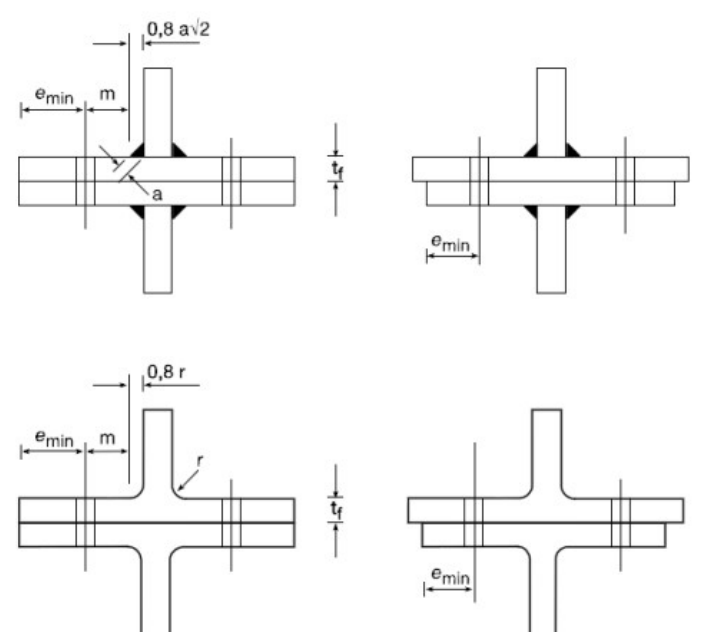

Fonte: EC3 Part. 1.8 (2005).

O comprimento efetivo da mesa do pilar à flexão não só depende das caraterísticas geométricas do pilar, mas também depende se esta é ou não reforçada. Se a mesa do pilar não

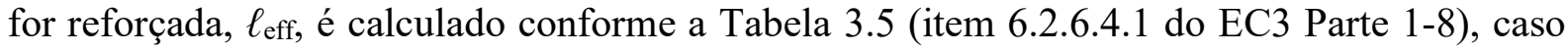

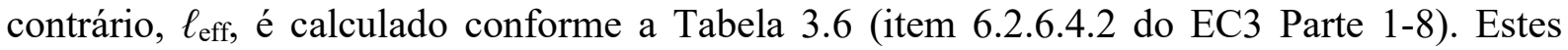
reforços, além de aumentarem a capacidade resistente da mesa, também dividem os conjuntos de linhas de parafusos. Assim, devem ser consideradas duas peças em T-stub equivalente, uma 


\section{4 | MODELO TEÓRICO}

para os parafusos situados acima do reforço e outra para os parafusos abaixo do reforço. Estas expressões variam de acordo com a posição da linha de parafusos, com a configuração do comprimento efetivo, que pode ser circular ou não, e com a possibilidade das linhas de parafusos atuarem em grupo. O modo de ruptura 1 é definido pelo menor valor calculado entre a configuração circular e não circular, enquanto que o modo 2 é sempre definido pela configuração não circular. Os termos configuração circular e não circular se referem às formas de charneiras plásticas que podem ocorrer na mesa do pilar ou na chapa de topo.

Tabela 3.5 - Comprimento efetivo da mesa do pilar não reforçado à flexão.

\begin{tabular}{|c|c|c|c|c|}
\hline \multirow[b]{2}{*}{$\begin{array}{l}\text { Localização da linha } \\
\text { de parafusos }\end{array}$} & \multicolumn{2}{|c|}{$\begin{array}{l}\text { Linha de parafusos considera } \\
\text { individualmente }\end{array}$} & \multicolumn{2}{|c|}{$\begin{array}{l}\text { Linha de parafusos considerada como } \\
\text { parte de um grupo de linhas }\end{array}$} \\
\hline & $\begin{array}{l}\text { Configuração } \\
\text { circular: } \\
1_{\text {eff,cp }}\end{array}$ & $\begin{array}{c}\text { Configuração não } \\
\text { circular: } \\
l_{\text {eff,nc }}\end{array}$ & $\begin{array}{c}\text { Configuração } \\
\text { circular: } \\
\text { leff,cp }\end{array}$ & $\begin{array}{l}\text { Configuração não } \\
\text { circular: } \\
l_{\text {eff,nc }}\end{array}$ \\
\hline $\begin{array}{c}\text { Linha de parafusos } \\
\text { interior }\end{array}$ & $2 \pi \mathrm{m}$ & $4 m+1,25 \mathrm{e}$ & $2 \mathrm{p}$ & $\mathrm{p}$ \\
\hline $\begin{array}{l}\text { Linha de parafusos } \\
\text { de extremidade }\end{array}$ & $\begin{array}{l}\text { Mínimo: } \\
2 \pi \mathrm{m} \\
\pi \mathrm{m}+2 \mathrm{e}_{1}\end{array}$ & $\begin{array}{c}\text { Mínimo: } \\
4 \mathrm{~m}+1,25 \mathrm{e} \\
2 \mathrm{~m}+0,625 \mathrm{e}+\mathrm{e}_{1}\end{array}$ & $\begin{array}{l}\text { Mínimo: } \\
\pi \mathrm{m}+\mathrm{p} \\
2 \mathrm{e}_{1}+\mathrm{p}\end{array}$ & $\begin{array}{c}\text { Mínimo: } \\
2 \mathrm{~m}+0,625 \mathrm{e}+0,5 \mathrm{p} \\
\mathrm{e}_{1}+0,5 \mathrm{p}\end{array}$ \\
\hline Modo 1 & \multicolumn{2}{|c|}{$1_{\mathrm{eff}, 1}=1_{\mathrm{eff}, \mathrm{nc}} \operatorname{mas} 1_{\mathrm{eff}, 1} \leq 1_{\mathrm{eff}, \mathrm{cp}}$} & \multicolumn{2}{|c|}{$\sum 1_{\mathrm{eff}, 1}=\sum \mathrm{l}_{\mathrm{eff}, \mathrm{nc}}$ mas $\sum \mathrm{l}_{\mathrm{eff}, 1} \leq \sum \mathrm{l}_{\mathrm{eff}, \mathrm{cp}}$} \\
\hline Modo 2 & \multicolumn{2}{|c|}{$1_{\text {eff }, 2}=1_{\text {eff,nc }}$} & \multicolumn{2}{|c|}{$\sum \mathrm{l}_{\mathrm{eff}, 2}=\sum \bar{l}_{\mathrm{eff}, \mathrm{nc}}$} \\
\hline
\end{tabular}

Fonte: EC3 Part. 1.8 (2005).

Tabela 3.6 - Comprimento efetivo da mesa do pilar reforçado à flexão.

\begin{tabular}{|c|c|c|c|c|}
\hline \multirow[b]{2}{*}{$\begin{array}{c}\text { Localização da linha de } \\
\text { parafusos }\end{array}$} & \multicolumn{2}{|c|}{$\begin{array}{l}\text { Linha de parafusos considera } \\
\text { individualmente }\end{array}$} & \multicolumn{2}{|c|}{$\begin{array}{c}\text { Linha de parafusos considerada como } \\
\text { parte de um grupo de linhas }\end{array}$} \\
\hline & $\begin{array}{l}\text { Configuração } \\
\text { circular: } \\
\text { l }_{\text {eff,cp }}\end{array}$ & $\begin{array}{l}\text { Configuração } \\
\text { não circular: } \\
1_{\text {eff,nc }}\end{array}$ & $\begin{array}{l}\text { Configuração } \\
\text { circular: } \\
1_{\text {eff,cp }}\end{array}$ & $\begin{array}{l}\text { Configuração não } \\
\text { circular: } \\
1_{\text {eff,nc }}\end{array}$ \\
\hline $\begin{array}{l}\text { Linha de parafusos } \\
\text { adjacente a um reforço }\end{array}$ & $2 \pi \mathrm{m}$ & $\alpha \mathrm{m}$ & $\pi \mathrm{m}+\mathrm{p}$ & $\begin{array}{c}0,5 p+\alpha m \\
-(2 m+0,625 e)\end{array}$ \\
\hline $\begin{array}{c}\text { Outra linha de parafusos } \\
\text { interior }\end{array}$ & $2 \pi \mathrm{m}$ & $4 m+1,25 e$ & $2 \mathrm{p}$ & $\mathrm{p}$ \\
\hline $\begin{array}{l}\text { Outra linha de parafusos } \\
\text { de extremidade }\end{array}$ & $\begin{array}{l}\text { Mínimo: } \\
2 \pi \mathrm{m} \\
\pi \mathrm{m}+2 \mathrm{e}_{1}\end{array}$ & $\begin{array}{c}\text { Mínimo: } \\
4 \mathrm{~m}+1,25 \mathrm{e} \\
2 \mathrm{~m}+0,625 \mathrm{e}+\mathrm{e}_{1}\end{array}$ & $\begin{array}{l}\text { Mínimo: } \\
\pi \mathrm{m}+\mathrm{p} \\
2 \mathrm{e}_{1}+\mathrm{p}\end{array}$ & $\begin{array}{c}\text { Mínimo: } \\
2 \mathrm{~m}+0,625 \mathrm{e}+0,5 \mathrm{p} \\
\mathrm{e}_{1}+0,5 \mathrm{p}\end{array}$ \\
\hline $\begin{array}{c}\text { Linha de parafuso de } \\
\text { extremidade adjacente a } \\
\text { um reforço }\end{array}$ & $\begin{array}{l}\text { Mínimo: } \\
2 \pi \mathrm{m} \\
\pi \mathrm{m}+2 \mathrm{e}_{1}\end{array}$ & $\begin{array}{c}\mathrm{e}_{1}+\alpha \mathrm{m} \\
-(2 \mathrm{~m}+0,625 \mathrm{e})\end{array}$ & Não aplicável & Não aplicável \\
\hline Modo 1 & \multicolumn{2}{|c|}{$1_{\text {eff }, 1}=1_{\text {eff,nc }}$ mas $1_{\text {eff }, 1} \leq 1_{\text {eff,cp }}$} & \multicolumn{2}{|c|}{$\sum \mathrm{l}_{\mathrm{eff}, 1}=\sum \mathrm{l}_{\mathrm{eff}, \mathrm{nc}}$ mas $\sum \mathrm{l}_{\mathrm{eff}, 1} \leq \sum \mathrm{l}_{\mathrm{eff}, \mathrm{cp}}$} \\
\hline Modo 2 & \multicolumn{2}{|c|}{$1_{\mathrm{eff}, 2}=1_{\mathrm{eff}, \mathrm{nc}}$} & \multicolumn{2}{|c|}{$\sum 1_{\mathrm{eff}, 2}=\sum \mathrm{l}_{\mathrm{eff}, \mathrm{nc}}$} \\
\hline
\end{tabular}

Fonte: EC3 Part. 1.8 (2005).

O valor do $e_{1}$ é a distância entre os centros dos parafusos da última linha e a extremidade adjacente livre da mesa do pilar, medida na direção do eixo do pilar, quando o pilar não tem continuidade e acaba no mesmo nível da chapa de extremidade, $e_{1}$ é igual a Figura 3.10a), quando o pilar tem continuidade, $e_{1}$ deve ser considerado até o piso seguinte, ou seja, igual ao pé direito (Figura 3.10b) e quando há reforço, o e 1 será a distância entre os centros dos parafusos 
da última linha e o reforço adjacente da mesa do pilar, medida na direção do eixo do pilar. O valor de p é a distância entre duas linhas de parafusos.

Figura 3.10 - Dimensão e em função da continuidade ou não do pilar.

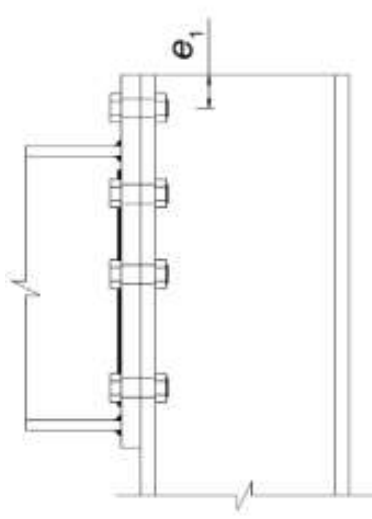

a)

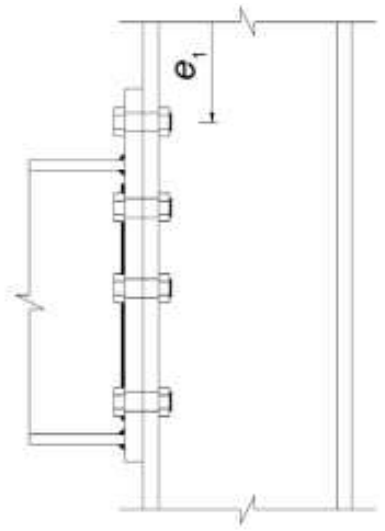

b)

Fonte: Vieito (2015).

Os valores de $\alpha$ são dados pelo ábaco da Figura 3.11, após o cálculo de $1 \lambda$ e $2 \lambda$. Salienta-se a forma como deve ser interpretada a imagem para o cálculo do valor $\alpha$.

Figura 3.11 - Valores de a para mesas de pilar enrijecidas e chapas de topo.
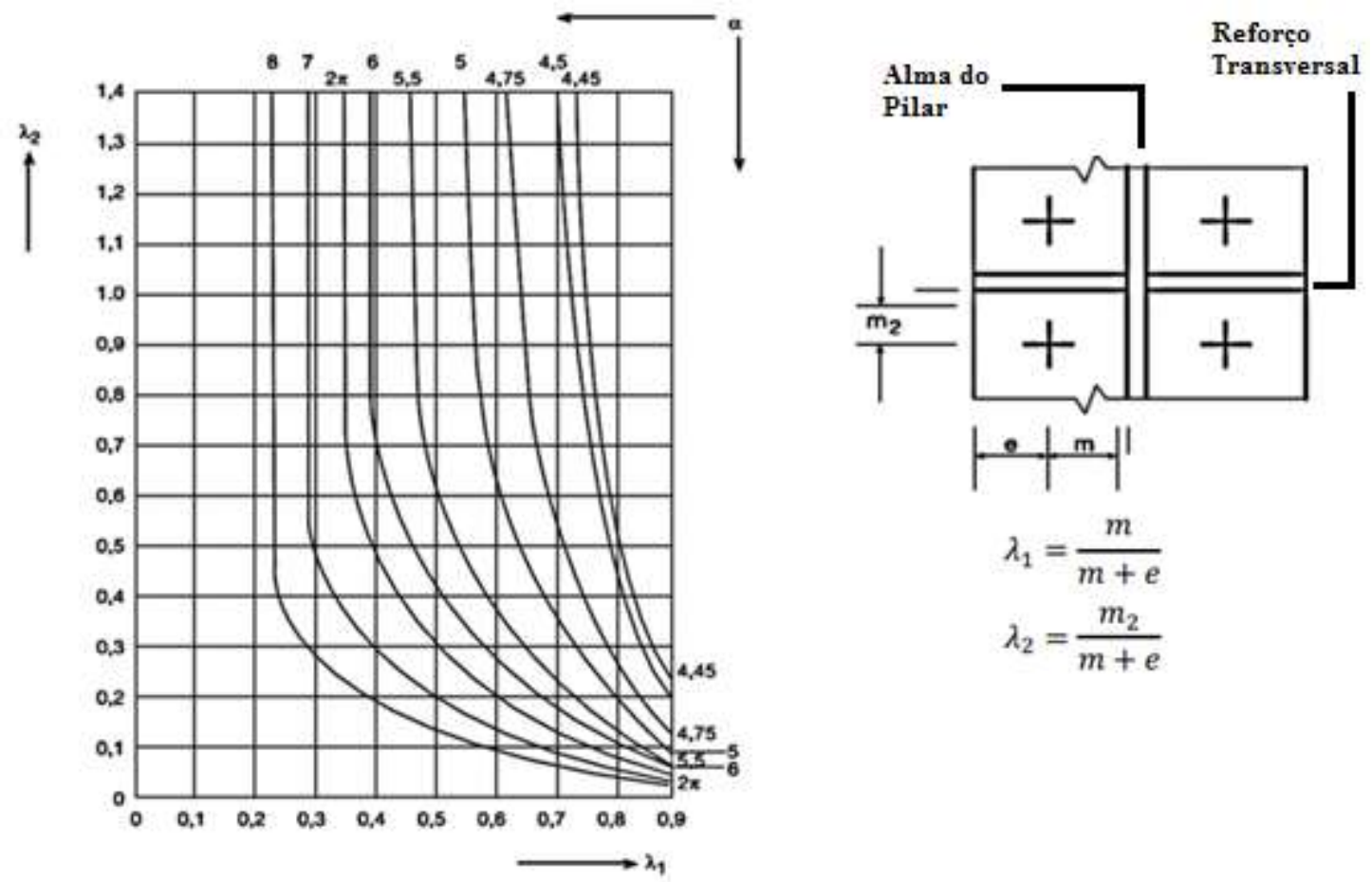

$$
\begin{aligned}
& \lambda_{1}=\frac{m}{m+e} \\
& \lambda_{2}=\frac{m_{2}}{m+e}
\end{aligned}
$$

Fonte: EC3 Part. 1.8 (2005).

Onde: $\mathrm{m}_{1}$ é igual a $m$; 


\section{6 | MODELO TEÓRICO}

$\mathrm{m}_{2}$ é a distância vertical do centro do parafuso à face do enrijecedor de alma do pilar, menos $80 \%$ da dimensão da solda entre a mesa do pilar e o enrijecedor.

$\mathrm{O}$ valor do coeficiente de rigidez da mesa do pilar em flexão $\left(\mathrm{k}_{4}\right)$ é obtido pela Equação 3.14 do item 6.3.2 do EC3 Parte 1-8 para uma linha de parafuso:

$$
k_{4}=\frac{0,9 l_{e f f} t_{f c}^{3}}{m^{3}}
$$

\subsubsection{Chapa de topo em flexão (componente 5)}

A determinação da capacidade resistente deste elemento é análoga ao procedimento da mesa do pilar em flexão, mas para o outro lado o que era o reforço transversal, agora é a mesa da viga. Assim, a formulação apresentada do perfil em T-stub equivalente é também aplicável a este elemento. Para este elemento, o comprimento efetivo, $1_{\text {eff }}$, é obtido de acordo com a cláusula 6.2.6.5 do EC3 Parte 1-8 e na Figura 3.12 exemplifica-se como se devem considerar as linhas de parafusos para cálculo do comprimento efetivo de uma chapa de topo e mostra-se como deve ser interpretada a imagem da figura 6.11 do EC3 Parte 1-8 para o cálculo do valor $\alpha$.

Figura 3.12 - Parâmetros geométricos para o cálculo do valor $\alpha$.

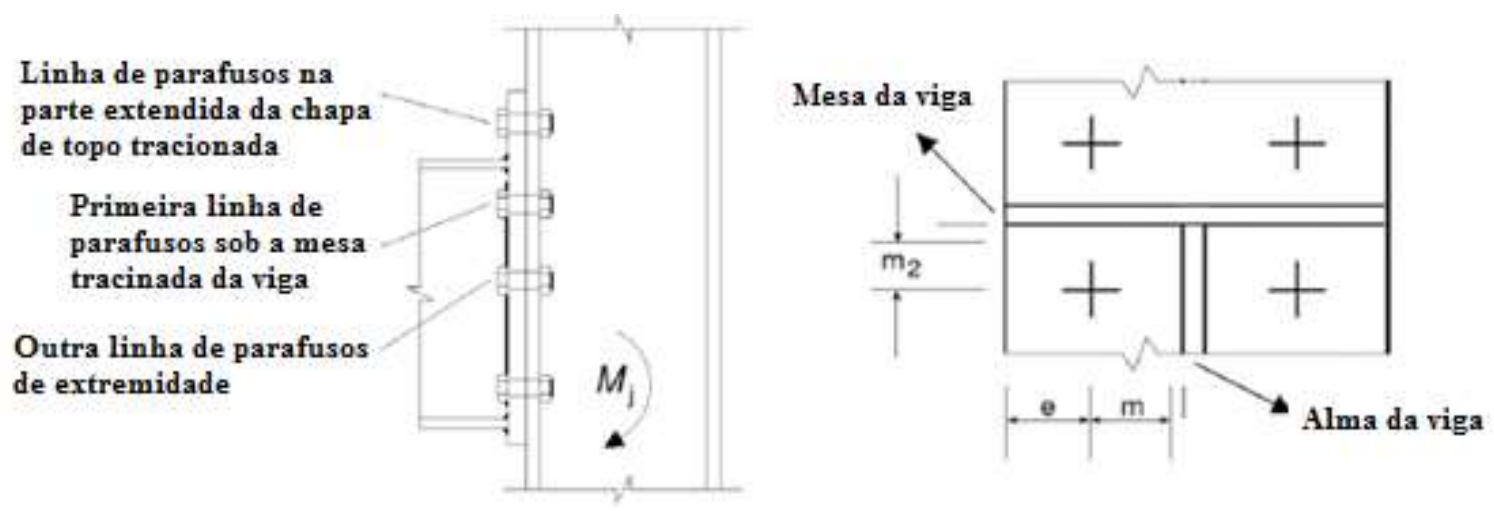

Fonte: Vieito (2015).

Com algumas diferenças nas definições geométricas, para determinar o comprimento efetivo da chapa de topo (Tabela 3.7) deve-se fazer as seguintes considerações:

- o parâmetro $e_{\min }$ da Figura 3.13 deverá ser usado para a parte da chapa contida entre as mesas da viga. Para a extensão da chapa o $e_{\min }$ é igual a $e_{x}$;

- na extensão da chapa os valores de $(e)$ e $(m)$ devem ser substituídos por $\left(e_{x}\right)$ e $\left(m_{x}\right)$. 
Tabela 3.7: Comprimento efetivo da chapa de topo à flexão.

\begin{tabular}{|c|c|c|c|c|}
\hline \multirow[b]{2}{*}{$\begin{array}{l}\text { Localização da linha } \\
\text { de parafusos }\end{array}$} & \multicolumn{2}{|c|}{$\begin{array}{l}\text { Linha de parafusos considera } \\
\text { individualmente }\end{array}$} & \multicolumn{2}{|c|}{$\begin{array}{l}\text { Linha de parafusos considerada } \\
\text { como parte de um grupo de linhas }\end{array}$} \\
\hline & $\begin{array}{l}\text { Configuração } \\
\text { circular: } \\
1_{\text {eff,cp }}\end{array}$ & $\begin{array}{c}\text { Configuração não } \\
\text { circular: } \\
1_{\text {eff,nc }}\end{array}$ & $\begin{array}{c}\text { Configuração } \\
\text { circular: } \\
1_{\text {eff,cp }}\end{array}$ & $\begin{array}{l}\text { Configuração não } \\
\text { circular: } \\
1_{\text {eff,nc }}\end{array}$ \\
\hline $\begin{array}{c}\text { Linha de parafusos } \\
\text { na extensão da chapa } \\
\text { de topo }\end{array}$ & $\begin{array}{l}\text { Mínimo: } \\
2 \pi \mathrm{m}_{\mathrm{x}} \\
\pi \mathrm{m}_{\mathrm{x}}+\mathrm{w} \\
\pi \mathrm{m}_{\mathrm{x}}+2 \mathrm{e}\end{array}$ & $\begin{array}{c}\text { Mínimo: } \\
4 \mathrm{~m}_{\mathrm{x}}+1,25 \mathrm{e}_{\mathrm{x}} \\
\mathrm{e}+2 \mathrm{~m}_{\mathrm{x}}+0,625 \mathrm{e}_{\mathrm{x}} \\
0,5 \mathrm{~b}_{\mathrm{p}} \\
0,5 \mathrm{w}+2 \mathrm{~m}_{\mathrm{x}}+0,625 \mathrm{e}_{\mathrm{x}}\end{array}$ & & \\
\hline $\begin{array}{l}\text { Primeira linha de } \\
\text { parafusos son a mesa } \\
\text { tracionada da viga }\end{array}$ & $2 \pi \mathrm{m}$ & $\alpha \mathrm{m}$ & $\pi \mathrm{m}+\mathrm{p}$ & $\begin{array}{c}0,5 p+\alpha m \\
-(2 m+0,625 e)\end{array}$ \\
\hline $\begin{array}{l}\text { Outra linha de } \\
\text { parafusos interior }\end{array}$ & $2 \pi \mathrm{m}$ & $4 m+1,25 \mathrm{e}$ & $2 \mathrm{p}$ & $\mathrm{p}$ \\
\hline $\begin{array}{l}\text { Outra linha de } \\
\text { parafusos de } \\
\text { extremidade }\end{array}$ & $2 \pi \mathrm{m}$ & $4 m+1,25 e$ & $\pi \mathrm{m}+\mathrm{p}$ & $2 \mathrm{~m}+0,625 \mathrm{e}+0,5 \mathrm{p}$ \\
\hline Modo 1 & \multicolumn{2}{|c|}{$1_{\mathrm{eff}, 1}=1_{\mathrm{eff}, \mathrm{nc}}$ mas $1_{\mathrm{eff}, 1} \leq 1_{\mathrm{eff}, \mathrm{cp}}$} & \multicolumn{2}{|c|}{$\sum 1_{\mathrm{eff}, 1}=\sum 1_{\mathrm{eff}, \mathrm{nc}} \operatorname{mas} \sum \mathrm{l}_{\mathrm{eff}, 1} \leq \sum \mathrm{l}_{\mathrm{eff}, \mathrm{cp}}$} \\
\hline Modo 2 & \multicolumn{2}{|c|}{$1_{\text {eff }, 2}=1_{\text {eff,nc }}$} & \multicolumn{2}{|c|}{$\sum 1_{\mathrm{eff}, 2}=\sum \bar{l}_{\mathrm{eff}, \mathrm{nc}}$} \\
\hline
\end{tabular}

Fonte: EC3 Part. 1.8 (2005).

Figura 3.13 - Consideração da chapa estendida em dois T-stubs.

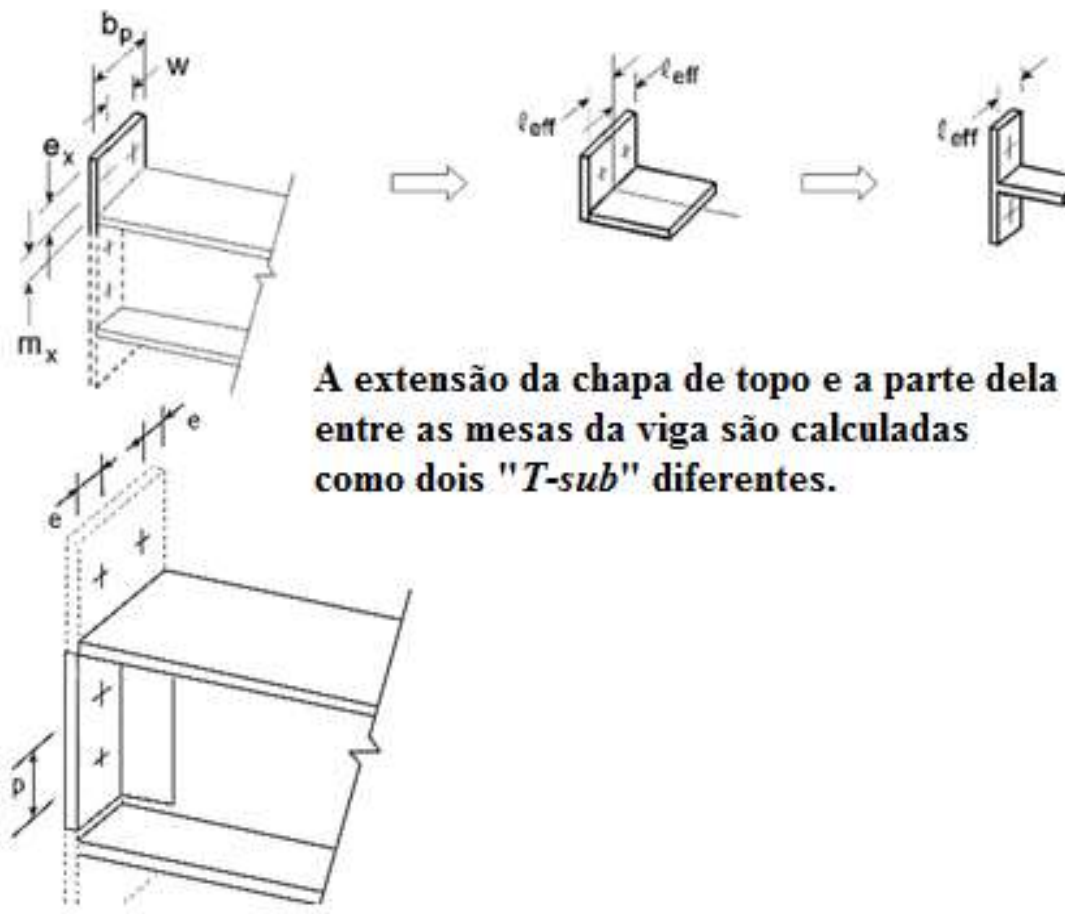

Fonte: EC3 Part. 1.8 (2005).

O valor do coeficiente de rigidez da chapa de topo em flexão $\left(k_{5}\right)$ é obtido da mesma maneira que para a mesa do pilar (Equação 3.15), onde $t_{p}$ é a espessura da chapa de topo: 


$$
k_{5}=\frac{0,9 l_{e f f} t_{p}^{3}}{m^{3}}
$$

\subsubsection{Mesa e alma da viga em compressão (componente 7)}

Semelhantemente à alma do pilar em compressão transversal, as tensões de compressão que ocorrem na mesa inferior e na alma da viga resultam do momento fletor negativo. A mesa e alma da viga em compressão atuam como um limite de resistência da ligação viga-pilar, fazendo com que esta não seja superior à resistência da viga. Assumindo que a tensão de compressão pode ser representada por uma força localizada no centro de compressão, a resistência de cálculo à compressão da mesa e da alma da viga combinadas é determinada pela seguinte Equação 3.16 do item 6.2.6.7 do EC3 Parte 1-8.

$$
F_{c, f b, R d}=\frac{M_{c, R d}}{\left(h-t_{f b}\right)}
$$

Em que:

$\mathrm{M}_{\mathrm{c}, \mathrm{Rd}}$ é o momento resistente de cálculo da viga, reduzido se necessário para considerar o efeito da força cortante;

h é a altura da viga;

$t_{\mathrm{fb}}$ é a espessura da mesa comprimida da viga.

O cálculo dos coeficientes de rigidez da alma e mesa da viga à compressão e da alma da viga à tração não é realizado, pois um comportamento rígido-plástico é considerado para estas componentes com coeficientes de rigidez iguais a infinito.

\subsubsection{Alma da viga em tração (componente 8)}

O processo de dimensionamento da alma da viga em tração é similar ao da alma do pilar em tração transversal (alma do T-stub equivalente), dependendo, neste caso, do comprimento efetivo (leff) da chapa de extremidade em flexão (componente 5). A resistência de cálculo à

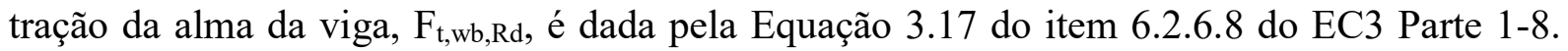
Recorda-se que em uma ligação com chapa de extremidade estendida, esta componente não deve ser contabilizada acima da mesa da viga.

$$
F_{t, w b, R d}=\frac{b_{e f f, t, w b} t_{w b} f_{y, w b}}{\gamma_{M 0}}
$$

Em que: 


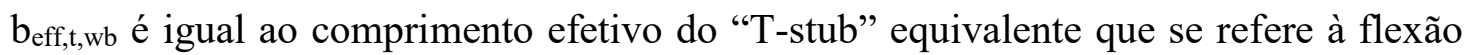
chapa de topo, obtido para linha de parafuso individual ou em grupo;

$f_{y, w b}$ é a tensão de escoamento da alma da viga;

$t_{w b}$ é a espessura da alma da viga.

\subsubsection{Parafuso à tração (componente 10)}

A ruptura dos parafusos à tração corresponde aos modos de ruptura 2 e 3 que são calculados com base no modelo T-stub equivalente. A resistência deste elemento é dada pelo somatório da resistência à tração individual de todos os parafusos que pertencem a linha de parafusos isolada ou grupo de linhas de parafusos. A resistência individual de cálculo de cada parafusos à tração, $\mathrm{F}_{\mathrm{t}, \mathrm{Rd}}$, é dada pela Equação 3.18. Apesar de não ser considerada como um componente básico das ligações e de não influenciar a rigidez da ligação, a resistência à punção da mesa do pilar ou da chapa de topo deve ser levada em conta no cálculo da resistência dos parafusos à tração. Assim, a resistência à punção da mesa do pilar ou da chapa de topo, $\mathrm{B}_{\mathrm{p}, \mathrm{Rd}}$, não deve ser inferior à resistência dos parafusos à tração (Equação 3.19).

$$
\begin{gathered}
F_{t, R d}=\frac{k_{2} f_{u b} A_{s}}{\gamma_{M 2}} \\
B_{p, R d}=\frac{0,6 \pi d_{m} t_{p} f_{u}}{\gamma_{M 2}} \\
F_{t, R d} \leq B_{p, R d}
\end{gathered}
$$

Em que

$\mathrm{k}_{2}$ é o coeficiente que para parafusos regulares considera-se igual a 0,9 ;

$f_{u b}$ é a tensão de ruptura do parafuso;

$\mathrm{A}_{\mathrm{s}}$ é a área da seção resistente do parafuso;

$\gamma_{\mathrm{M} 2}$ é o coeficiente de segurança para ligações igual a 1,25;

$\mathrm{d}_{\mathrm{m}}$ é a largura da cabeça do parafuso ou da porca;

$t_{p}$ é a espessura da chapa;

$f_{u}$ é a tensão de ruptura da chapa.

O valor do coeficiente de rigidez do parafuso à tração $\left(\mathrm{k}_{10}\right)$ é obtido pela Equação 3.20 do item 6.3.2 do EC3 Parte 1-8:

$$
k_{10}=\frac{1,6 A_{s}}{L_{b}}
$$




\subsubsection{Cisalhamento do parafuso (componente 11)}

A resistência de cálculo de cada parafuso ao cisalhamento, $F_{\mathrm{v}}$, Rd, é dada pela Equação 3.21 abaixo:

$$
F_{v, R d}=\frac{\alpha_{v} f_{u b} A}{\gamma_{M 2}}
$$

Em que $\alpha_{\mathrm{v}}$ é um coeficiente que depende onde o plano de corte atravessa o parafuso, na rosca ou não, e A é a seção transversal bruta do parafuso.

No caso em que o parafuso está sujeito à tração e ao cisalhamento ao mesmo tempo, a seguinte condição deve ser verificada para combinação de esforços:

$$
\frac{F_{v, E d}}{F_{v, R d}}+\frac{F_{t, E d}}{1,4 F_{t, R d}} \leq 1
$$

$\mathrm{O}$ valor do coeficiente de rigidez do parafuso ao cisalhamento $\left(\mathrm{k}_{11}\right)$ é determinado pela Equação 3.22 do item 6.3.2 do EC3 Parte 1-8:

$$
k_{11}=\frac{16 n_{b} d^{2} f_{u b}}{E d_{M 16}}
$$

Onde $\mathrm{d}_{\mathrm{M} 16}$ é o diâmetro nominal de um parafuso M16 e $\mathrm{n}_{\mathrm{b}}$ é o número de linhas de parafusos solicitados ao cisalhamento.

\subsubsection{Verificação da segurança à flexão}

A verificação da segurança à flexão segue a seguinte condição:

$$
M_{j, E d} \leq M_{j, R d}
$$

O valor de cálculo do momento resistente de uma ligação é determinado a partir da resistência de cálculo das componentes básicas aos esforços submetidos (forças internas). Estas componentes são organizadas em grupos (tração, compressão e cisalhamento) e o momento resistente da ligação é influenciado pelas resistências de cálculo mínimas destes grupos. O valor do momento resistente de cálculo de uma ligação, $\mathrm{M}_{\mathrm{j}, \mathrm{Rd}}$, é dado pela Equação 3.23 (item 6.2.7.2 do EC3 Parte 1- 8).

$$
M_{j, R d}=\sum_{r} h_{r} F_{t r, R d}
$$

Em que:

$\mathrm{F}_{\text {tr,Rd }}$ é o valor de cálculo da resistência à tração efetiva da linha de parafusos $r$;

$h_{\mathrm{r}}$ é a distância entre a linha de parafusos $\mathrm{r}$ e o centro de compressão; 
r é o número da linha de parafusos.

Em ligações com chapa de topo, as linhas são numeradas a partir da linha mais afastada do centro de compressão que deve ser considerado como o plano situado na metade da espessura da mesa comprimida do elemento ligado. Considerando as linhas como isoladas ou como parte de um grupo, a seguir descreve-se o processo de cálculo da resistência à tração efetiva de cada uma dessas linhas.

1) A resistência à tração efetiva de cada linha de parafusos, $F_{t r, R d}$, é igual à menor resistência de cálculo entre as componentes 3,4,5 e 8, calculadas como linhas isoladas ou como parte de um grupo. No caso de uma ligação com chapa de topo estendida, para a linha de parafusos fora da mesa da viga a componente 8 é excluída;

2) Para garantir o equilíbrio de forças e o aumento do momento resistente, a soma da resistência à tração efetiva das linhas de parafusos tem de ser igual à menor resistência de cálculo entre as componentes 2,7 e componente $1 / \beta$. Se o somatório das forças de tração ultrapassar o menor valor das resistências, a resistência das linhas de parafusos tem de ser reduzida até igualar a essa resistência.

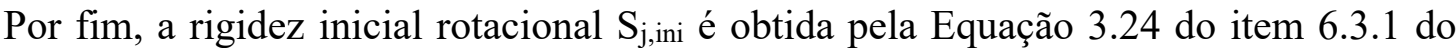
EC3 Parte 1-8:

$$
S_{j, i n i}=\frac{E z^{2}}{\mu \sum_{i} \frac{1}{k_{i}}}
$$

Onde E é o módulo de elasticidade do aço;

$\mathrm{O}$ valor do braço de alavanca $\mathrm{z}$ é obtido segundo a Tabela 3.8 para ligação viga-pilar com chapa de topo;

O valor de $\mu$ é obtido por:

Se $\mathrm{M}_{\mathrm{j}, \mathrm{Ed}} \leq 2 / 3 \mathrm{M}_{\mathrm{j}, \mathrm{Rd}}, \mu=1$

$\mathrm{Se}^{2} / 3 \mathrm{M}_{\mathrm{j}, \mathrm{Rd}}<\mathrm{M}_{\mathrm{j}, \mathrm{Ed}} \leq \mathrm{M}_{\mathrm{j}, \mathrm{Rd}}, \mu=\left(\frac{1,5 M_{j, E d}}{M_{j, R d}}\right)^{2,7}$ para ligações com chapa de topo; 
Tabela 3.8 - Centro de compressão, braço de alavanca e distribuição de esforços.

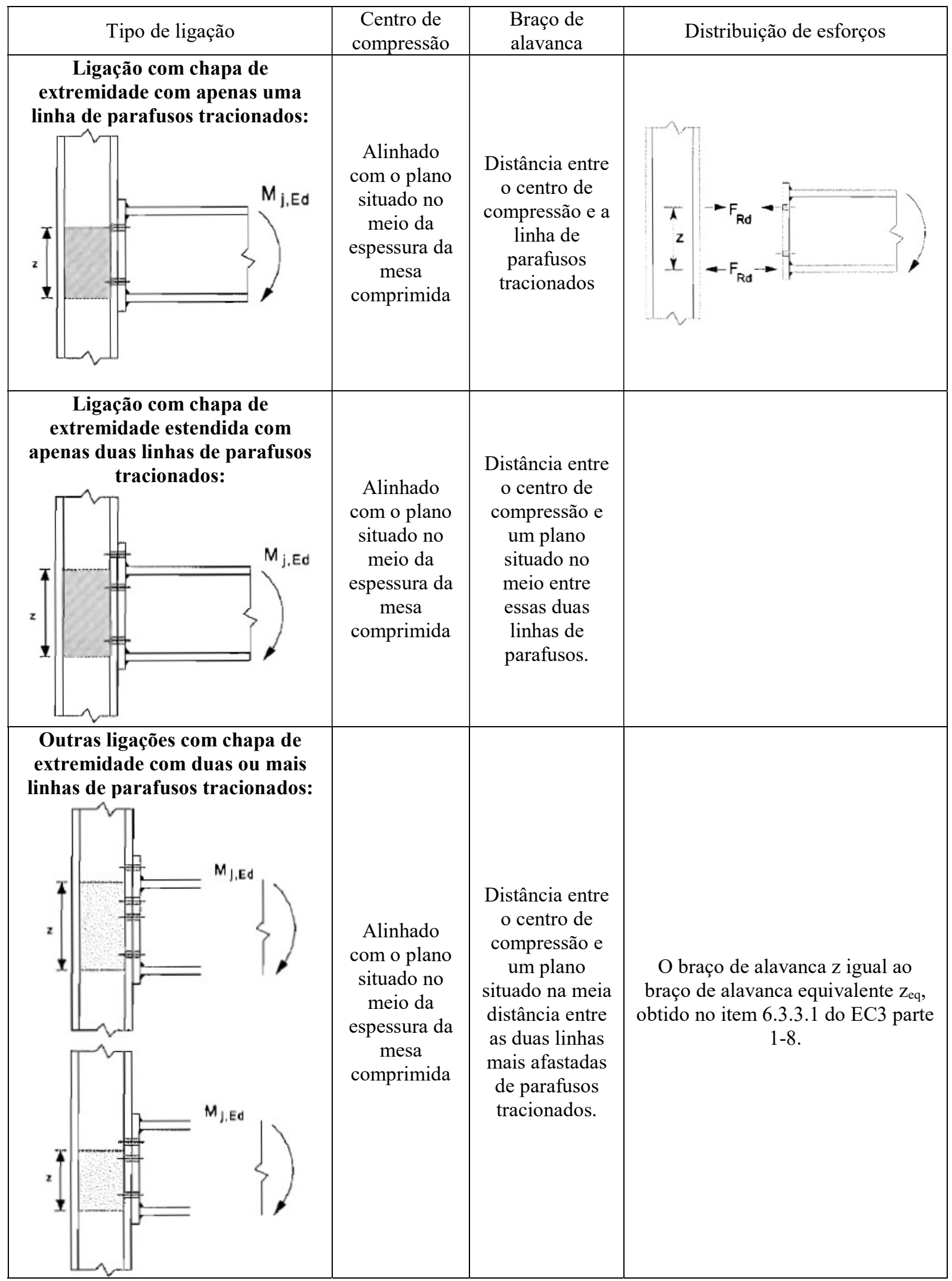

Fonte: EC3 Part. 1.8 (2005). 
Os valores $k_{i}$ são os coeficientes definidos de rigidez elástica de cada componente. Para ligações com chapa de topo e parafusos, os coeficientes que devem ser considerados no caso de ligação cruciforme com momentos iguais e opostos são: $\mathrm{k}_{2}, \mathrm{k}_{3}, \mathrm{k}_{4}$, $\mathrm{k}_{5}$ e $\mathrm{k}_{10}$ para uma linha de parafusos tracionados, e $\mathrm{k}_{2}$ e $\mathrm{k}_{\text {eq }}$ para duas linhas ou mais. No último caso, os componentes básicos relativos à ligação são representados por um coeficiente de rigidez equivalente $\left(\mathrm{k}_{\mathrm{eq}}\right)$, calculado pelas Equações 3.25 a 3.27:

$$
\begin{gathered}
k_{e q}=\frac{\sum_{r} k_{e f f, r} h_{r}}{z_{e q}} \\
k_{e f f, r}=\frac{1}{\sum_{i \frac{i}{k_{i, r}}}^{1}} \\
z_{e q}=\frac{\sum_{r} k_{e f f, r} h_{r}^{2}}{\sum_{r} k_{e f f, r} h_{r}}
\end{gathered}
$$

Onde $k_{\text {eff,r }}$ é o coeficiente de rigidez efetivo para linha de parafusos $r$, levando em conta os coeficientes de rigidez listados dos componentes básicos.

\subsection{Dimensionamento de Ligação Viga-pilar segundo ABNT NBR 8800}

O dimensionamento de uma ligação significa a verificação de todas as partes que a compõem: os elementos de ligação e os meios de ligação. Como meio de ligação são utilizados frequentemente soldas, parafusos e barras rosqueadas. De acordo com a ABNT NBR 8800 (2008), os meios de ligação são dimensionados como mostra a Tabela 3.9 a seguir.

Tabela 3.9 - Quadro resumo das expressões da ABNT NBR 8800 (2008).

$$
\begin{aligned}
& \text { Ligações por contato }
\end{aligned}
$$

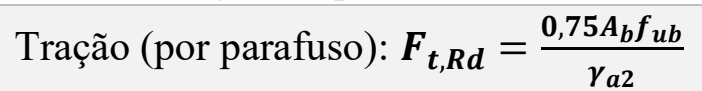

Onde $\mathrm{f}_{\mathrm{ub}}$ é a resistência à ruptura do material à tração; $\mathrm{A}_{\mathrm{b}}$ é a área bruta do parafuso ou da barra rosqueada considerando o diâmetro externo da rosca; $\gamma_{\mathrm{a} 2}$ é o coeficiente de ponderação da resistência relacionado à ruptura.

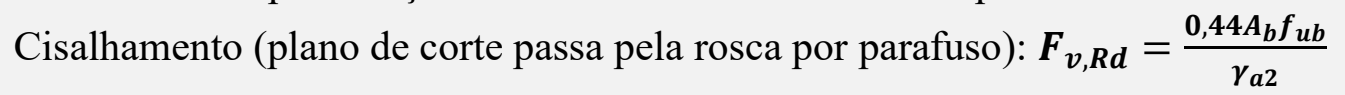

Cisalhamento (plano de corte não passa pela rosca por parafuso): $\boldsymbol{F}_{\boldsymbol{v}, \boldsymbol{R d}}=\frac{\boldsymbol{0 , 5}_{\boldsymbol{a}} \boldsymbol{A}_{\boldsymbol{u} \boldsymbol{b}}}{\boldsymbol{\gamma}_{\boldsymbol{a} 2}}$

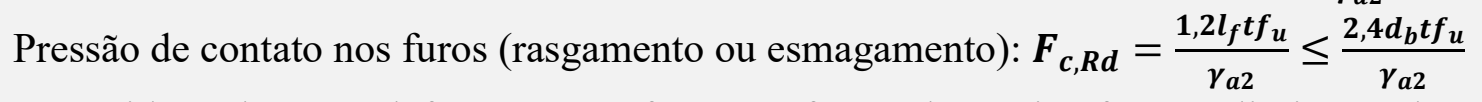

Considerando que a deformação no furo para forças de serviço for uma limitação de projeto na direção da força.

Onde $\mathrm{l}_{\mathrm{f}}$ é a distância entre a borda do furo e a borda do furo adjacente ou borda livre; $\mathrm{d}_{\mathrm{b}}$ é o diâmetro do parafuso; t é a espessura da parte ligada; $f_{u}$ é a resistência à ruptura do aço da parede do furo. 


$$
\text { Tração e Cisalhamento Combinados: }\left(\frac{F_{t, S d}}{F_{t, R d}}\right)^{2}+\left(\frac{F_{v, S d}}{F_{v, R d}}\right)^{2} \leq 1
$$

Onde $\mathrm{F}_{\mathrm{t}, \mathrm{Sd}}$ é a força de tração solicitante de cálculo por parafuso; $\mathrm{F}_{\mathrm{V}, \mathrm{Sd}}$ é a força de cisalhamento solicitante de cálculo no plano considerado do parafuso.

\section{Ligações por atrito}

Resistência ao deslizamento (ELU): $F_{f, R d}=\frac{1,13 \mu C_{h} F_{T b} n_{s}}{\gamma_{e}}\left(1-\frac{F_{t, S d}}{1,13 F_{T b}}\right) \geq V_{S d}$

Resistência ao deslizamento (ELS): $F_{f, R k}=0,8 \mu C_{h} F_{T b} n_{s}\left(1-\frac{F_{t, S k}}{0,8 F_{T b}}\right) \geq V_{S k}$

Conforme as combinações últimas e de serviço especificadas no item 6.3.4

Onde $\mu$ é o coeficiente de atrito médio; $\mathrm{C}_{\mathrm{h}}$ é o fator de furo; $\mathrm{F}_{\mathrm{Tb}}$ é a força de protensão mínima por parafuso; $\mathrm{n}_{\mathrm{s}}$ é o número de planos de deslizamento; $\gamma_{\mathrm{e}}$ é o coeficiente de ponderação da resistência; $\mathrm{V}_{\mathrm{Sd}}$ é a força cortante solicitante de cálculo; $\mathrm{V}_{\mathrm{Sk}}$ é a força cortante solicitante característica.

\section{Ligações soldadas}

\section{Cisalhamento na seção efetiva de solda filete Metal da solda: $\boldsymbol{F}_{\boldsymbol{w}, \boldsymbol{R} d}=\frac{\mathbf{0 , 6} \boldsymbol{A}_{\boldsymbol{w}} \boldsymbol{f}_{\boldsymbol{w}}}{\gamma_{\boldsymbol{w} \mathbf{2}}}$}

Onde $A_{w}$ é a área efetiva da solda; $f_{w}$ é a resistência mínima do metal da solda.

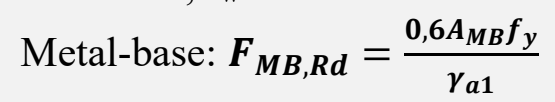

Onde $\mathrm{A}_{\mathrm{MB}}$ é a área do metal-base (comprimento de solda multiplicado pela espessura do metal-base menos espesso); $f_{\mathrm{y}}$ é a menor resistência ao escoamento entre os metais-base da junta; $\gamma_{\mathrm{w} 2}$ e $\gamma_{\mathrm{a} 1}$ são os coeficientes de ponderação da resistência.

Na ABNT NBR 8800 (2008) é indicada também a verificação da solda de penetração.

Como foi visto, para o equilíbrio de forças, as linhas de parafusos não devem estar submetidas apenas às solicitações advindas das forças externas, mas deve-se levar em conta o “efeito alavanca" (Q) no qual a flexão da chapa de ligação induz um acréscimo de tração no parafuso devido à restrição da deformação das extremidades desta chapa por este. Se a chapa é espessa, ela praticamente não apresenta deformação por flexão sob ação do carregamento (ruptura dos parafusos), diferentemente do que acontece com chapas menos espessas, que tendem a se deformar e escoar. Por isso, limita-se a espessura da chapa de topo e da mesa do pilar em relação à resistência dos parafusos, procurando-se evitar que os parafusos externos entrem em colapso antes que os parafusos internos escoem. O valor da força de alavanca depende diretamente da geometria da ligação, podendo dispensar uma análise mais rigorosa desta com a redução da força de tração resistente do parafuso $\left(\mathrm{F}_{\mathrm{t}, \mathrm{Rd}}\right)$ em: $33 \%$ se as espessuras das chapas das partes ligadas forem calculadas com base no momento resistente plástico e $25 \%$ se as espessuras das chapas das partes ligadas forem calculadas com base no momento resistente elástico. 
Conforme De Nardin et al. (2012), no caso da ligação com chapa passante, a resistência última na chapa passante pode ser estimada considerando que sua resistência ao cisalhamento é função da área líquida da seção, reduzida pelos furos, levando em conta a interação entre a força de cisalhamento e o momento devido à excentricidade. Já os parafusos submetidos ao cisalhamento devem ser verificados utilizando os estados limites aplicáveis neste caso: cisalhamento do parafuso e pressão de contato em furos.

Este item apresentou os procedimentos normativos para dimensionamento de ligações viga-pilar segundo a norma brasileira - ANBT NBR 8800 (2008) - e pela norma europeia EC3 Part. 1.8 (2005). Verificou-se que os modelos apresentados de dimensionamento de ligações viga-pilar pela norma europeia são mais detalhados que os apresentados pela norma brasileira. As tipologias de ligação encontradas na literatura serviram de base para a definição dos detalhes a serem investigados nos modelos físicos. Buscaram-se alguns dispositivos de ligação no eixo de maior e menor inércia dos pilares parcialmente revestidos que permitam sua maior utilização. Em relação aos dispositivos de ligação, não há normas aplicáveis diretamente aos detalhes propostos neste trabalho. Portanto, o estudo inicial de dimensionamento das ligações propostas, que será apresentado, resulta de simplificações nas recomendações existentes para detalhes de ligação entre elementos de aço e estudos mais aprofundados são necessários. 


\section{INVESTIGAÇÃO EXPERIMENTAL}

O programa experimental foi realizado no Laboratório de Estruturas do Departamento de Engenharia de Estruturas da Escola de Engenharia de São Carlos - USP que consistiu de ensaios estáticos cruciformes de ligações viga-pilar, nas quais as vigas são de aço e os pilares parcialmente revestidos com concreto. O planejamento do programa experimental com ligações viga-pilar considerou os recursos que eram limitados. Desta forma, descartou-se uma análise experimental de ligações mistas com a presença da laje de concreto. Assim, o trabalho focou em apenas um detalhe de ligação.

Um estudo piloto de duas tipologias de ligação entre pilares mistos e vigas de aço foi desenvolvido por meio de investigação experimental para determinar qual tipologia de ligação e geometria seriam adotadas nos ensaios definitivos e sua instrumentação. A investigação experimental foi definida através dos trabalhos já desenvolvidos no departamento com o objetivo de dar continuidade a eles, utilizando os perfis de aço disponíveis em laboratório e as tipologias de ligação já estudadas: chapa de topo com barras passantes e chapas passantes. $\mathrm{O}$ ensaio dos modelos pilotos ajudou a visualizar o comportamento das ligações viga-pilar parcialmente revestido na direção de menor momento de inércia do pilar, estabelecer o esquema de instrumentação adequado, além de verificar a viabilidade do esquema de ensaio, adotandose a tipologia ligação com chapa de topo e barras passantes para a próxima etapa.

A partir da previsão da capacidade resistente por meio da simulação numérica e recomendações normativas presentes na ABNT NBR 8800 e no EC3 (Anexo A), foi realizada a experimentação física dos modelos definitivos. De acordo com os parâmetros de interesse para este trabalho, seis modelos físicos foram suficientes para determinação da influência do eixo de inércia do pilar e a presença do revestimento de concreto com fibras na ligação. As comparações foram realizadas sempre em termos de capacidade resistente e rigidez da ligação. Os resultados experimentais foram relacionados com a rigidez global das ligações, os campos de deslocamento descritos pelas vigas, as deformações medidas em pontos da ligação e a observação dos estados limites últimos.

Devido às limitações encontradas na instrumentação pela grande quantidade de extensômetros ou pela inacessibilidade dos equipamentos de leitura, os modelos numéricos foram empregados em todas as fases do estudo. Complementando a análise experimental, a análise paramétrica foi desenvolvida para fornecer dados adicionais e para gerar discussões sobre o comportamento das ligações com chapa de topo. 
A seguir, os detalhes da investigação experimental no estudo das ligações são descritos, assim como as tipologias de ligação investigadas, equipamentos e procedimentos utilizados. Também são apresentados e discutidos os resultados experimentais e no próximo capítulo a simulação numérica será utilizada para expandir esses resultados.

\subsection{Descrição dos Modelos}

Os modelos físicos foram constituídos de um pilar parcialmente revestido com concreto e duas vigas de aço em balanço, ligadas a ele por meio de barras passantes, aderentes ao concreto do núcleo, e chapa de topo ou chapas passantes e parafusos. Essa configuração em formato cruciforme simula o comportamento de um pilar intermediário. Aqui as características geométricas de cada uma das tipologias de ligação dos modelos físicos, que foram investigadas por meio de experimentação física e simulação numérica, são descritas. Na Tabela 4.1 são resumidas as principais características de cada uma das tipologias investigadas que serão apresentadas detalhadamente.

Tabela 4.1 - Características gerais das tipologias de ligação.

\begin{tabular}{|c|c|c|}
\hline Ensaio & Ligação & Características \\
\hline \multirow{7}{*}{ Piloto } & $\begin{array}{c}\text { Tipologia 1: ligação } \\
\text { parafusada com aderência, } \\
\text { pilar misto e viga de aço }\end{array}$ & $\begin{array}{c}\text { Chapa de topo + barra passante, com aderencia entre as barras e } \\
\text { o núcleo de concreto convencional do pilar parcialmente } \\
\text { revestido no eixo de menor momento de inércia. }\end{array}$ \\
\cline { 2 - 4 } & $\begin{array}{c}\text { Tipologia 2: ligação com } \\
\text { chapa passante, pilar misto e } \\
\text { viga de aço }\end{array}$ & $\begin{array}{c}\text { Chapa passante + parafuso + chapa adicional na região } \\
\text { comprimida, com aderência entre as chapas passantes e o núcleo } \\
\text { de concreto do pilar misto no eixo de menor momento de inércia. }\end{array}$ \\
\hline \multirow{7}{*}{ Definitivo } & $\begin{array}{c}\text { Tipologia 3: ligação } \\
\text { parafusada, pilar misto e } \\
\text { viga de aço }\end{array}$ & $\begin{array}{c}\text { Chapa de topo estendida + parafusos, com a interrupção do } \\
\text { concreto convencional do pilar parcialmente revestido na ligação } \\
\text { e no eixo de maior momento de inércia. }\end{array}$ \\
\cline { 2 - 3 } & $\begin{array}{c}\text { Tipologia 4: ligação } \\
\text { parafusada com aderência, } \\
\text { pilar misto e viga de aço }\end{array}$ & $\begin{array}{c}\text { Tipologia 5: ligação } \\
\text { parafusada com aderência, } \\
\text { pilar misto e viga de aço } \\
\text { barras e o núcleo de concreto com fibras do pilar parcialmente } \\
\text { revestido no eixo de maior momento de inércia. }\end{array}$ \\
\cline { 2 - 3 } & $\begin{array}{c}\text { Tipologia 6: ligação } \\
\text { parafusada, pilar misto e } \\
\text { viga de aço }\end{array}$ & $\begin{array}{c}\text { Chapa de topo estendida + barra passante, com aderência entre as } \\
\text { barras e o núcleo de concreto com fibras do pilar parcialmente } \\
\text { revestido no eixo de menor momento de inércia. }\end{array}$ \\
\hline
\end{tabular}

Fonte: Elaborado pela autora.

Nos detalhes de ligação viga-pilar, as vigas utilizadas tanto na composição do modelo físico quanto do modelo numérico têm as dimensões ilustradas na Figura 4.1, com dois eixos 
de simetria e $1650 \mathrm{~mm}$ de comprimento. Além disso, todas as vigas têm enrijecedores a 150 mm das extremidades livres e todos os perfis são constituídos por aço ASTM A572.

Figura 4.1 - Dimensões da viga de aço nos modelos piloto e definitivo (mm).

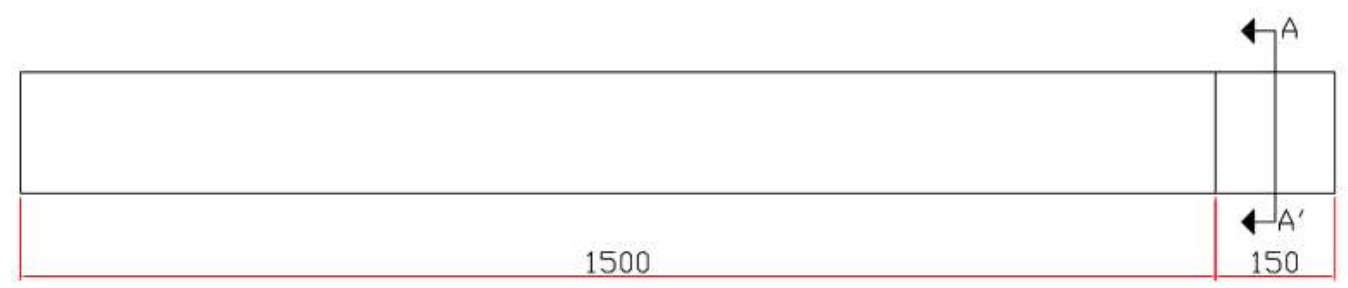

Corte $A A^{\prime}$

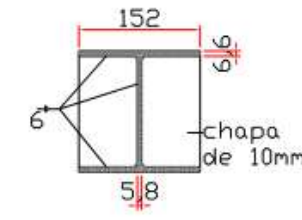

a) Viga w150×22,5

Ensaio Piloto

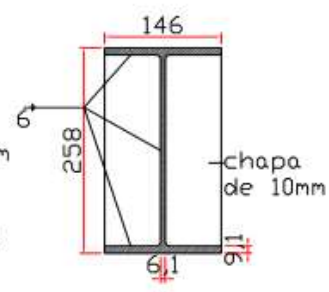

b) Viga W250×32,7

Ensaio Definitivo

Fonte: Elaborado pela autora.

Os perfis para composição de todos os pilares parcialmente revestidos são perfis laminados W (150x22,5 kg/m) com $2000 \mathrm{~mm}$ de comprimento. Nas extremidades inferior e superior do perfil foram soldadas chapas com $10 \mathrm{~mm}$ de espessura, que tem a função de impedir a saída do concreto fresco e para aplicação do carregamento. Como material de revestimento foi utilizado um concreto de $35 \mathrm{MPa}$ de resistência à compressão.

De acordo com as características do concreto de revestimento, da armadura e da ligação, identificam-se seis configurações de seções transversais dos pilares parcialmente revestidos de concreto que estão apresentadas nas Figuras 4.2 e 4.3, utilizadas por Pereira (2017). Os ensaios pilotos foram realizados para primeira configuração mostrada na Figura 4.2. Já os ensaios definitivos foram realizados para a segunda configuração representada pela Figura 4.3.

Figura 4.2 - Pilares mistos dos modelos pilotos ( $\mathrm{mm}$ ).

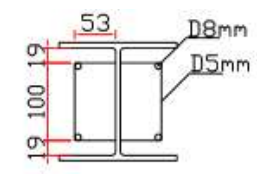

Modelo 1
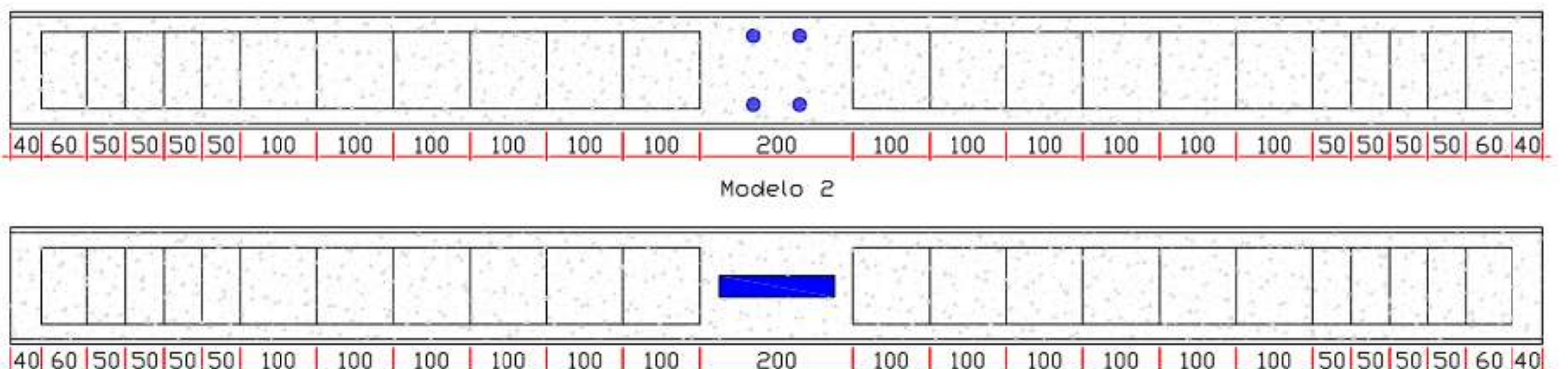

Fonte: Elaborado pela autora. 
Figura 4.3 - Pilares mistos dos modelos definitivos (mm).

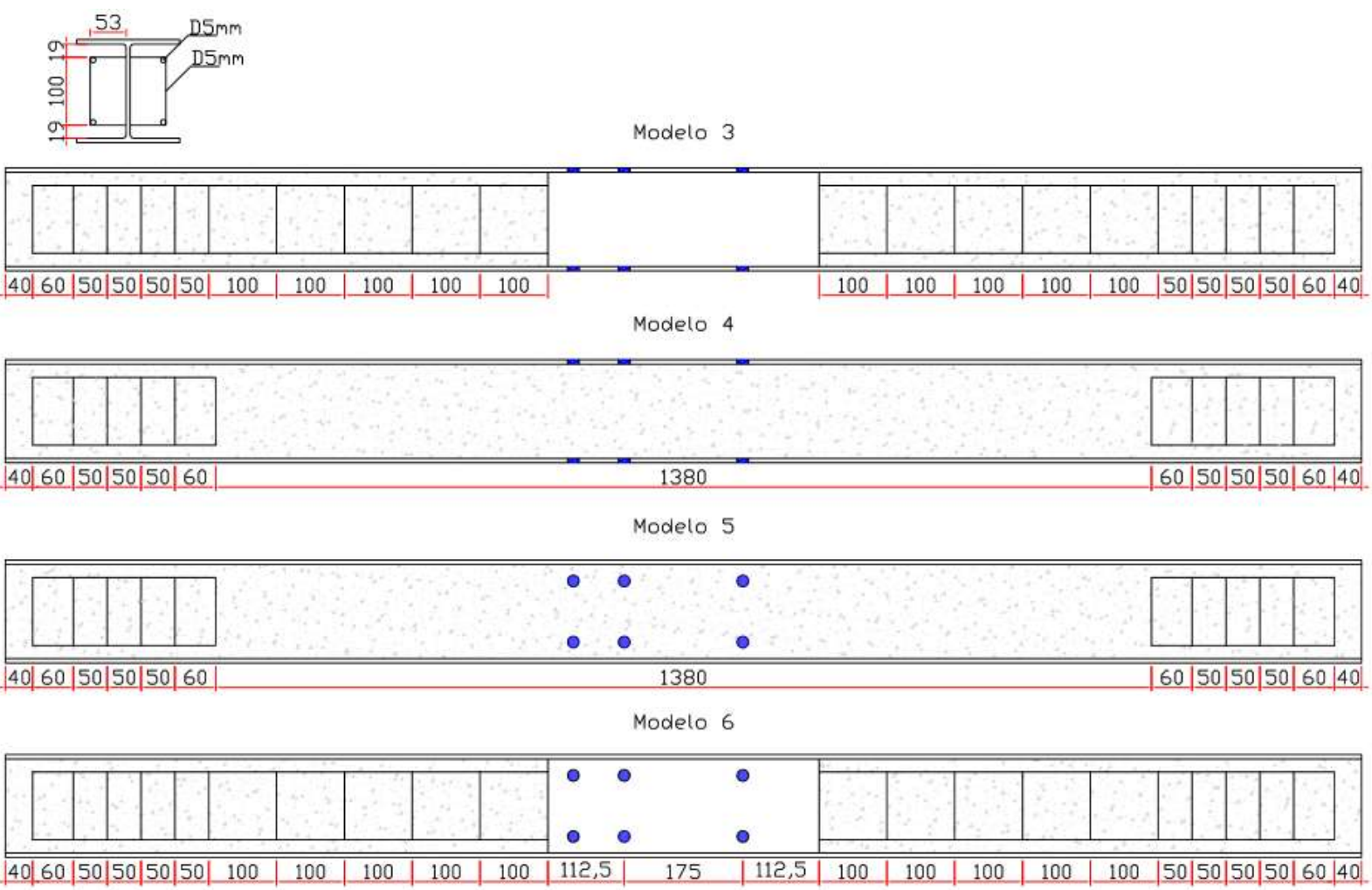

Fonte: Elaborado pela autora.

A primeira configuração é composta por concreto e armadura convencionais (armadura transversal e longitudinal). A armadura longitudinal é formada por quatro barras de $8 \mathrm{~mm}$ de diâmetro o que corresponde a uma taxa de armadura de $0,99 \%$. Salienta-se que a armadura transversal é soldada no perfil de aço utilizando-se solda do tipo MIG. Já na segunda configuração, a armadura discreta é eliminada e substituída pela adição aleatória de fibras de aço no concreto de revestimento nos modelos 4 e 5 . No caso dos modelos 3 e 6 , o concreto convencional é interrompido na região da ligação.

\subsection{Detalhamento das Tipologias de Ligação}

As dimensões da chapa de topo dependem do diâmetro dos parafusos $\left(\mathrm{d}_{\mathrm{b}}\right)$ respeitando, segundo as recomendações da ABNT NBR 8800 (2008), as distâncias mínimas de $2 \mathrm{~d}_{\mathrm{b}}$ entre os furos e as extremidades da chapa de topo ou a face da mesa da viga, e de $3 \mathrm{~d}_{\mathrm{b}}$ entre centros de furos. Assim, as dimensões adotadas para as chapas de topo nos modelos físicos, considerando- 
se parafusos de $16,0 \mathrm{~mm}$, são apresentadas nas Figuras 4.4 a 4.8 que trazem as principais dimensões das tipologias estudadas.

A Tipologia 1 é composta por chapas de extremidade com $10 \mathrm{~mm}$ de espessura e quatro barras rosqueadas com $15 \mathrm{~mm}$ de diâmetro e $430 \mathrm{~mm}$ de comprimento, denominadas "barras passantes", promovendo ligação no eixo de menor momento de inércia do pilar. Essas barras DYWIDAG são constituídas por aço de alta resistência e são utilizadas usualmente como tirantes. Sua escolha foi devido a sua rosca robusta que proporciona máxima aderência aço/concreto, característica fundamental para garantir uma transferência de força adequada entre os elementos, possuindo um diâmetro externo de $17 \mathrm{~mm}$. Detalhes desta tipologia são dados na Figura 4.4.

Figura 4.4-Dimensões da tipologia 1 (mm).

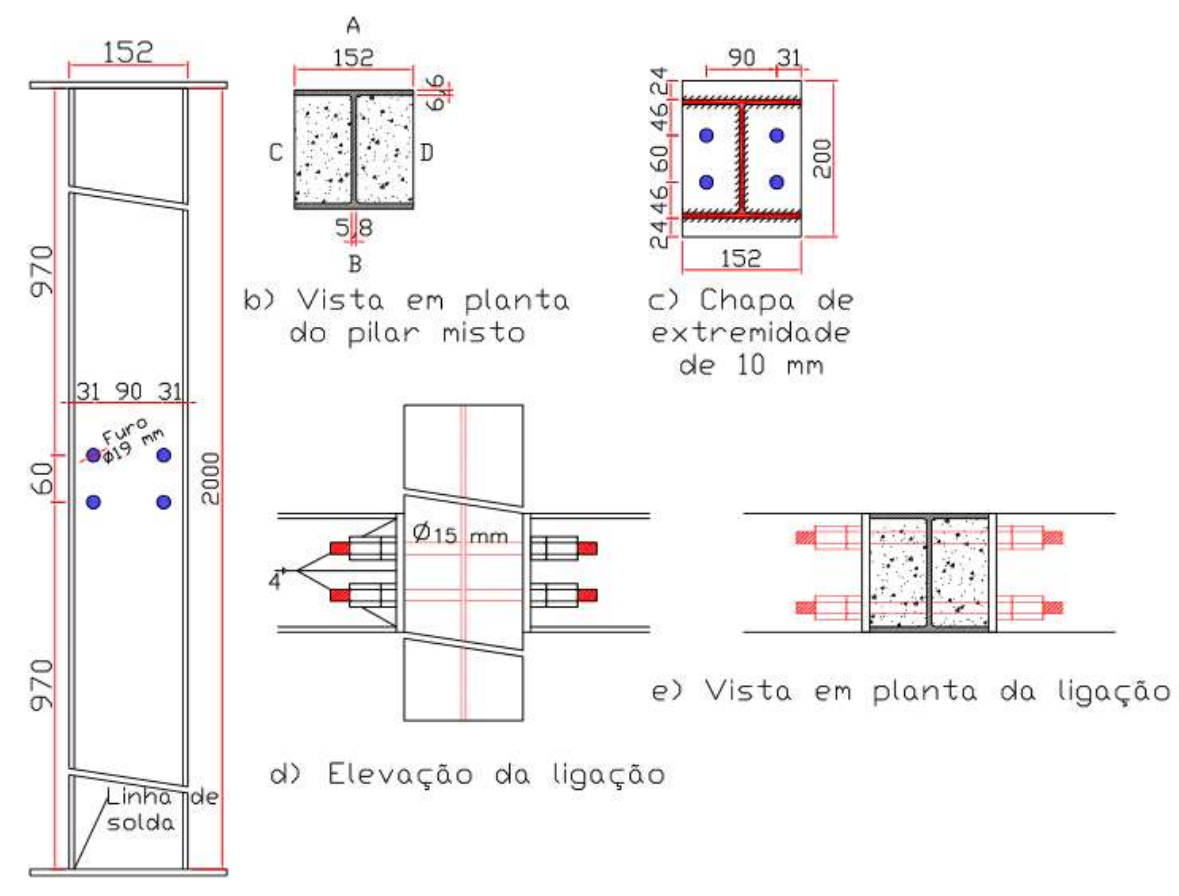

a) Elevação pilar misto
Faces $C$ e D

Fonte: Elaborado pela autora.

Diferentemente, a Tipologia 2 é formada por duas chapas enrijecedoras de $10 \mathrm{~mm}$, denominadas "chapas passantes", e parafusos de alta resistência do tipo ASTM-A325 com 16 mm de diâmetro no eixo de menor momento de inércia do pilar. Detalhes desta tipologia são mostrados na Figura 4.5. 
Figura 4.5 - Dimensões da tipologia 2 (mm).

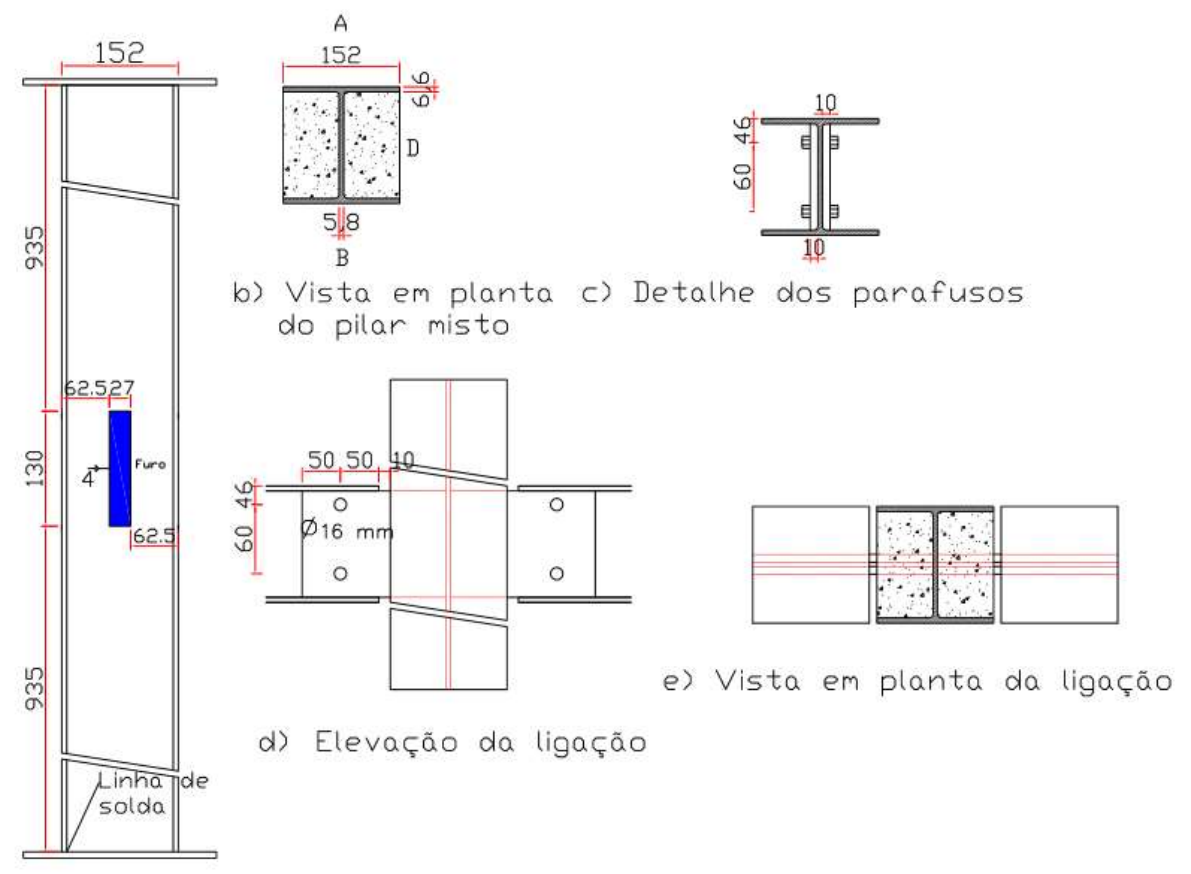

a) Elevação pilar misto

Faces $C$ e D

Fonte: Elaborado pela autora.

Já a Tipologia 3 é composta por chapas de topo estendidas com $16 \mathrm{~mm}$ de espessura e seis parafusos de alta resistência do tipo ASTM-A325 com 16 mm de diâmetro no eixo de maior momento de inércia do pilar e com interrupção do concreto na ligação, sendo considerada base de comparação para os outros modelos, pois é o modelo previsto em norma e usualmente utilizado em construções civis (Figura 4.6).

Nas Tipologias 4 e 5, apenas a espessura da chapa de topo e a direção do eixo do pilar diferem entre si. Elas são constituídas por seis barras passantes de alta resistência com diâmetro de $15 \mathrm{~mm}$ e comprimento de $430 \mathrm{~mm}$, e chapas de topo estendidas com 16 ou 22,2 $\mathrm{mm}$ de espessura nos eixos de maior ou menor momento de inércia, respectivamente, sem a interrupção do concreto com fibras na ligação (Figuras 4.7 e 4.8). 
Figura 4.6-Dimensões da tipologia 3 ( $\mathrm{mm})$.

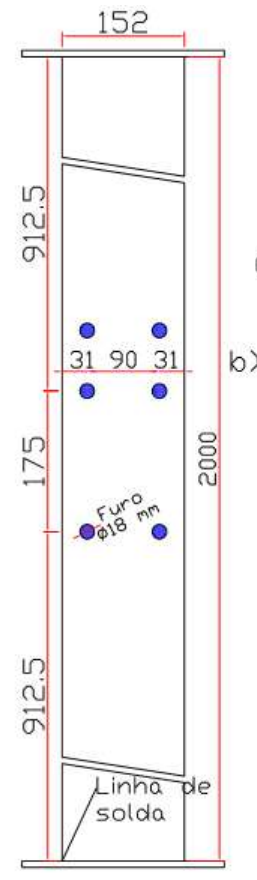

a) Elevação pilar misto Faces $A$ e $B$

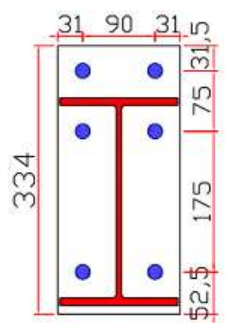

c) chapa de extremidade

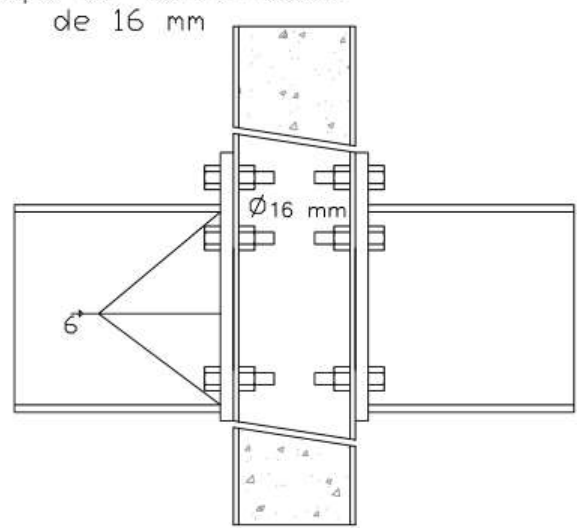

e) Elevação da ligação

Fonte: Elaborado pela autora.

Figura 4.7 - Dimensões da tipologia 4 ( $\mathrm{mm})$.

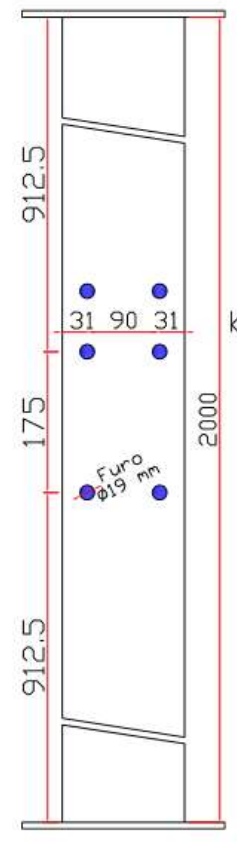

a) Elevação pilar misto Faces $A$ e $B$

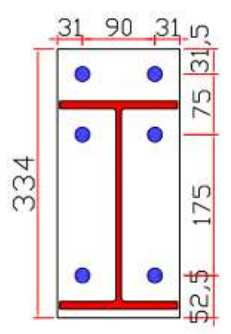

c) chapa de extremidade

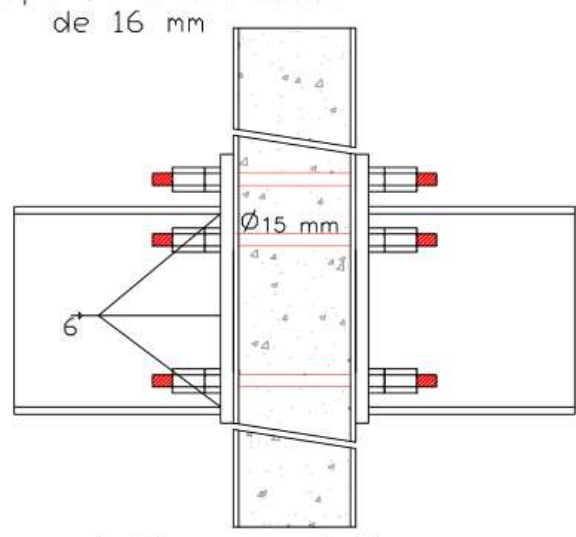

e) Elevação da ligação

Fonte: Elaborado pela autora.

Por fim, a Tipologia 6 é constituída por chapas de topo estendidas com 22,2 $\mathrm{mm}$ de espessura apoiadas nas extremidades da mesa do pilar, pois há a interrupção do concreto na 
ligação, e seis barras passantes de alta resistência com diâmetro de $15 \mathrm{~mm}$ e comprimento de $430 \mathrm{~mm}$ (Figura 4.8).

Figura 4.8 - Dimensões das tipologias 5 e $6(\mathrm{~mm})$.
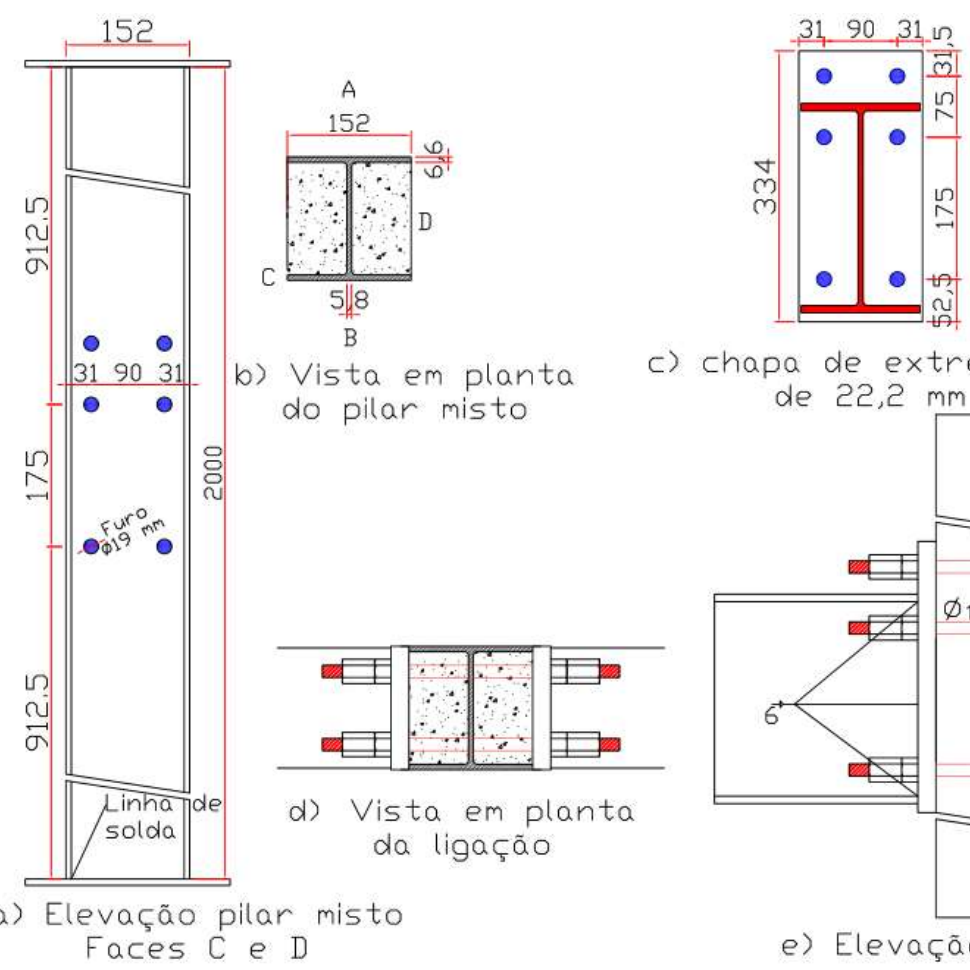

c) chapa de extremidade

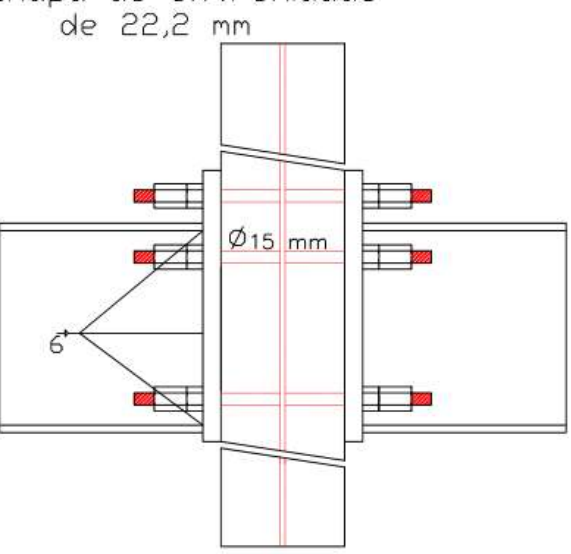

e) Elevação da ligação

Fonte: Elaborado pela autora.

\subsection{Programa Experimental}

\subsubsection{Considerações Iniciais}

Os modelos investigados abordam o pilar parcialmente revestido como um obstáculo à continuidade das vigas, nas quais predomina o momento fletor, e as soluções aqui apresentadas visam minimizar esse obstáculo. Portanto, buscou-se um dispositivo de ligação que permita uma maior utilização dos pilares parcialmente revestidos. Os modelos físicos foram dimensionados, instrumentados e ensaiados considerando as limitações dos equipamentos disponíveis no Laboratório de Estruturas. 


\section{4 | INVESTIGAÇÃO EXPERIMENTAL}

\subsubsection{Ensaio de Caracterização dos Materiais}

Na composição dos modelos de ligação foram utilizados dois materiais: aço e concreto. Para ambos, os ensaios de caracterização foram realizados a fim de se obter as relações tensãodeformação e aplicá-las na modelagem numérica. Para o concreto e o aço, os ensaios realizados e o número de corpos de prova são mostrados na Tabela 4.2 e na Figura 4.9.

Tabela 4.2 - Corpos de prova utilizados na caracterização dos materiais das tipologias de ligação.

\begin{tabular}{|c|c|c|c|}
\hline \multicolumn{4}{|c|}{ Concreto: 12 corpos de prova $(10 \times 20) \mathrm{cm}$} \\
\hline Modelo & n. CP's & Idade & Ensaio \\
\hline \multirow{2}{*}{$\begin{array}{l}\text { Tipologias } 1,2,3 \\
4,5 \text { e } 6\end{array}$} & 4 & \multirow{2}{*}{28} & $\begin{array}{c}\text { Compressão } \\
\text { Módulo de Elasticidade }\end{array}$ \\
\hline & 4 & & Tração por compressão diametral \\
\hline \multicolumn{4}{|c|}{ Aço: determinação da resistência ao escoamento e resistência última } \\
\hline Modelo & \multicolumn{2}{|c|}{ n. CP's* } & Elemento \\
\hline \multirow{6}{*}{$\begin{array}{l}\text { Tipologias } 1,3,4, \\
5 \text { e } 6\end{array}$} & \multicolumn{2}{|c|}{3} & Alma do pilar \\
\hline & \multicolumn{2}{|c|}{3} & Mesa do pilar \\
\hline & \multicolumn{2}{|c|}{3} & Alma da viga \\
\hline & \multicolumn{2}{|c|}{3} & Mesa da viga \\
\hline & \multicolumn{2}{|c|}{3} & Chapa de topo \\
\hline & \multicolumn{2}{|c|}{$1 * *$} & Barra passante \\
\hline \multirow{5}{*}{ Tipologia 2} & \multicolumn{2}{|c|}{3} & Alma do pilar \\
\hline & \multicolumn{2}{|c|}{3} & Mesa do pilar \\
\hline & \multicolumn{2}{|c|}{3} & Alma da viga \\
\hline & \multicolumn{2}{|c|}{3} & Mesa da viga \\
\hline & \multicolumn{2}{|c|}{3} & Chapa passante \\
\hline \multicolumn{4}{|c|}{$\begin{array}{l}* \text { Segundo recomendações da ASTM A370:2017. } \\
\text { **Peça com } 85 \mathrm{~cm} \text { de comprimento, instrumentada a } 42 \mathrm{~cm} \text { da extremidade com } \\
\text { um extensômetro elétrico para aço e ensaiada somente uma vez. }\end{array}$} \\
\hline
\end{tabular}

Fonte: Elaborado pela autora.

Figura 4.9 - Os corpos de provas para determinação das propriedades mecânicas.

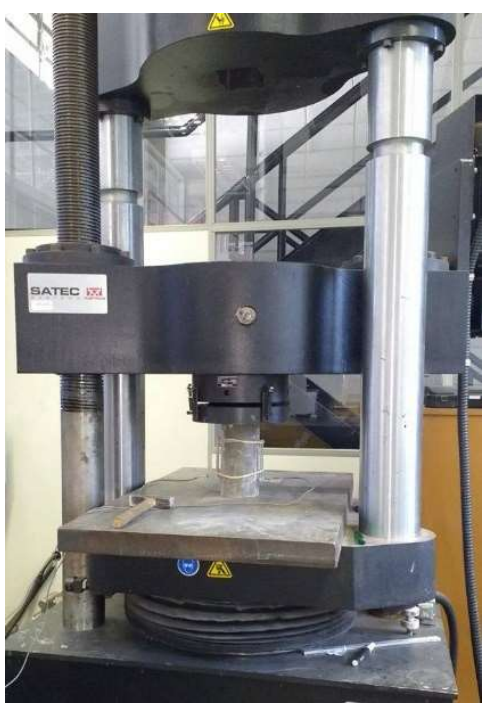

a) Concreto

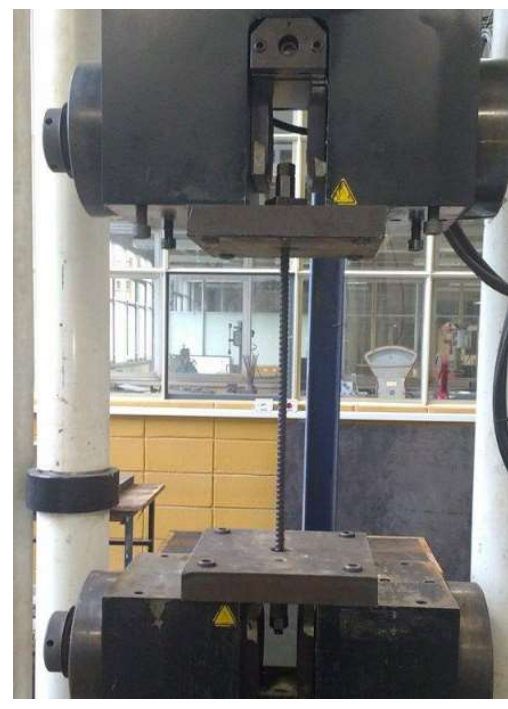

b) Barra passante

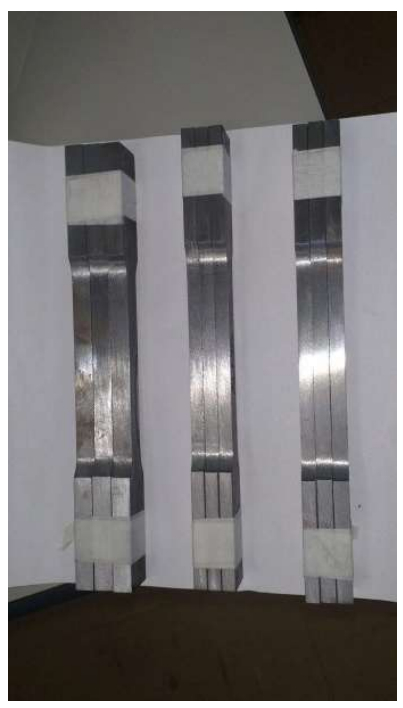

c) aço

Fonte: Elaborado pela autora. 
Os ensaios de caracterização do aço dos perfis foram feitos segundo a norma brasileira ABNT NBR ISO 6892-1 (2013). Por meio desses ensaios foram definidos a tensão de escoamento do aço e seu módulo de elasticidade. Três corpos de prova de cada elemento de aço foram ensaiados à tração, sendo eles: mesa e alma do pilar, mesa e alma da viga, armadura longitudinal e transversal, barra passante, chapa de topo e chapa passante. Os corpos de prova das barras passantes e das armaduras tinham aproximadamente $900 \mathrm{~mm}$ de comprimento. Para a determinação do módulo de elasticidade foi utilizado um extensômetro de base removível colocado no centro das barras, gerando as curvas tensão e deformação para cada corpo de prova.

Devido às limitações das máquinas servo-hidráulicas INSTRON modelos 8506 e 300 HVL disponíveis no Laboratório de Estruturas do Departamento de Engenharia de Estruturas da Escola de Engenharia de São Carlos - USP, não foi possível realizar os ensaios de tração dos parafusos ASTM-A325 sem usinagem, utilizando-se as propriedades mecânicas fornecidas pelo fabricante.

Os ensaios de caracterização feitos para o concreto foram os de compressão (segundo a norma ABNT NBR 5739 (2018)), módulo de elasticidade e tração por compressão diametral (conforme a norma ABNT NBR 7222 (2011)). Para cada ensaio foram moldados quatro corpos de prova cilíndricos com $100 \mathrm{~mm}$ de diâmetro e $200 \mathrm{~mm}$ de altura. A cura dos corpos de prova foi realizada em câmara úmida. O módulo de elasticidade foi obtido por meio dos dados de tensão e deformação do ensaio de compressão na INSTRON 300 HVL.

O mesmo traço do concreto de revestimento foi adotado em todos os modelos de ligações, variando a adição ou não de fibras de aço. A caracterização do concreto foi feita no dia do ensaio da ligação, totalizando 190 dias após a concretagem do perfil de aço nos ensaios definitivos e 60 dias após a concretagem do perfil de aço nos ensaios pilotos. Ressalta-se que o importante na pesquisa não era a idade do concreto, mas sim, que sua resistência à compressão fosse determinada no dia do ensaio da ligação.

\subsubsection{Moldagem, Adensamento e Cura}

Primeiramente, a preparação dos modelos foi realizada antes da concretagem por meio da soldagem das armaduras e das chapas passantes, da realização dos furos para passagem da ligação no pilar e da instrumentação do perfil de aço do pilar misto. As barras passantes foram posicionadas com o auxílio de chapas de MDF furadas de acordo com a chapa de topo. 


\section{6 | INVESTIGAÇÃO EXPERIMENTAL}

A concretagem dos pilares mistos ocorreu em duas etapas, primeiro de um lado e sete dias depois do lado oposto (Figura 4.10). Brita, areia, cimento ARI, água, aditivo superplastificante e fibras de aço foram misturados em betoneira comum, utilizando o traço de Pereira (2017). A concretagem foi realizada dentro do galpão de ensaios do Laboratório de Estruturas e o adensamento feito com vibrador de agulha. A cura dos modelos no galpão de ensaios foi feita através da cobertura por lonas, para evitar perda prematura de água.

Figura 4.10 - Concretagem dos pilares mistos.

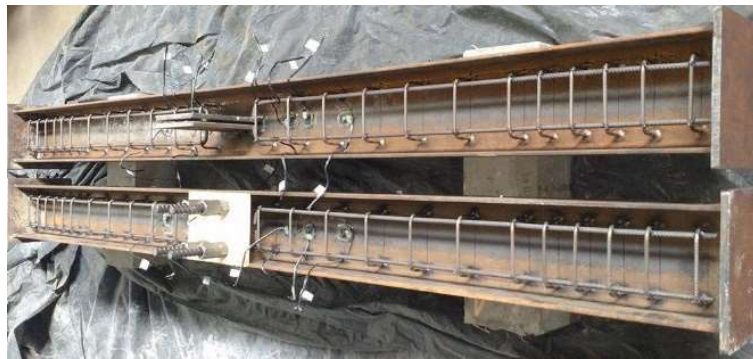

a) Tipologias 1 e 2 antes da concretagem

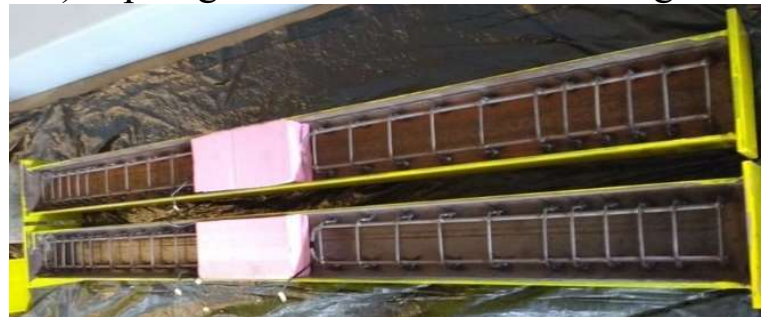

c) Tipologias 3 e 6 antes da concretagem

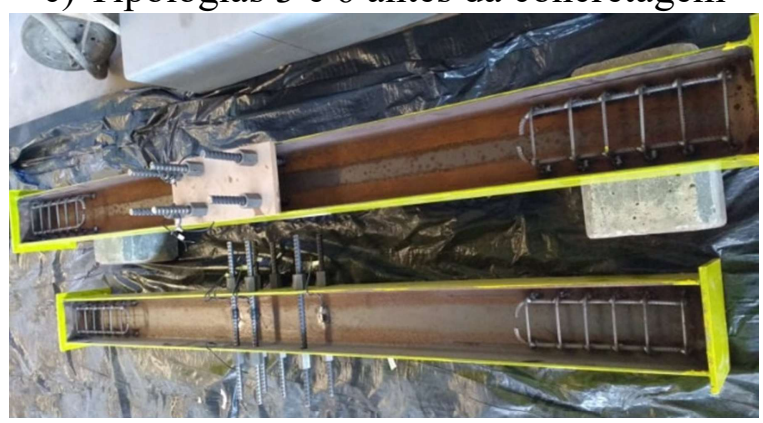

e) Tipologias 4 e 5 antes da concretagem

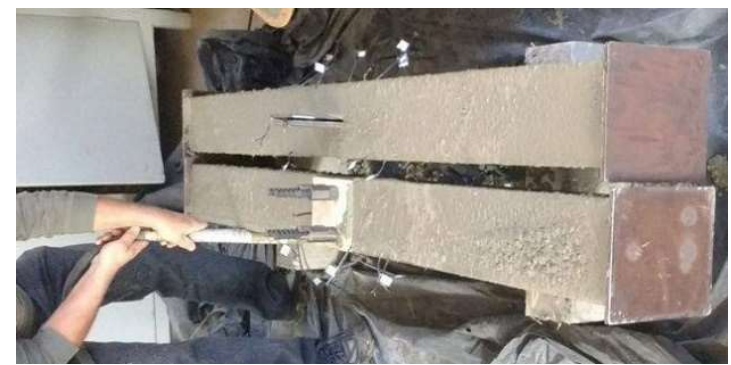

b) Tipologias 1 e 2 depois da concretagem

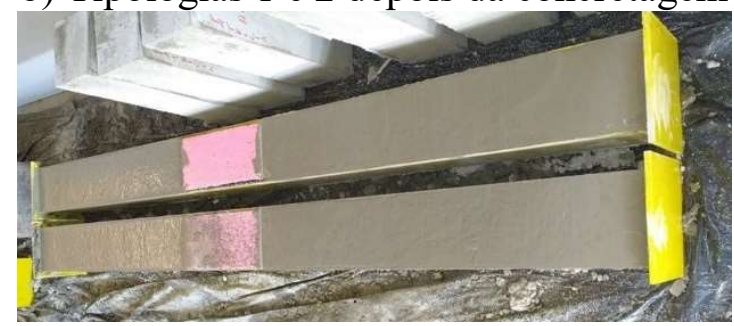

d) Tipologias 3 e 6 depois da concretagem

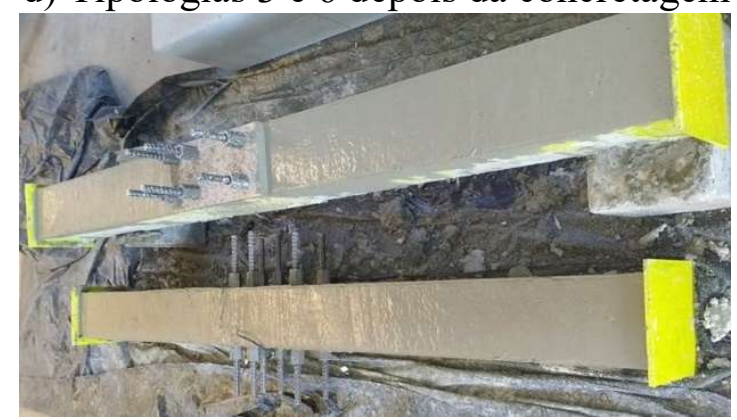

f) Tipologias 4 e 5 depois da concretagem

Fonte: Elaborado pela autora.

Vale lembrar também que as etapas da construção devem ser planejadas para que as atividades de montagem da estrutura metálica e do lançamento do concreto não afetem a estabilidade da estrutura com sobrecargas nos elementos de aço antes da concretagem e não afetem o andamento da obra. A sequência de execução das atividades da ligação proposta seria, primeiro, a montagem dos elementos de aço e suas ligações e, posteriormente, a concretagem das vigas mistas e dos pilares parcialmente revestidos, envolvendo as ligações. 


\subsubsection{Instrumentação}

Para determinar os valores de deformação e deslocamento em diversos pontos das tipologias de ligação estudadas, foram utilizados extensômetros elétricos e transdutores de deslocamento. Algumas fotos que detalham a instrumentação para registro de deformações são apresentadas na Figura 4.11. A instrumentação nas tipologias de ligação foi feita para se obterem os seguintes resultados:

- Deformações nas mesas comprimida e tracionada das vigas e alma das vigas, ao longo da sua altura, para acompanhamento da plastificação e observação da posição da linha neutra. As deformações das vigas foram determinadas com a utilização de dois extensômetros nas mesas superiores e inferiores e de três extensômetros distribuídos na altura da alma;

- Deformações no pilar misto na altura das mesas comprimidas e tracionadas das vigas para acompanhamento da plastificação;

- Deformações nas barras passantes tracionadas para acompanhamento da plastificação e controle das deformações para comparações com os resultados numéricos. Para instrumentação das barras passantes, estas foram lixadas na região central eliminando a rosca nesta porção. Após isso, foi colado o extensômetro e foi feito seu isolamento para impedir que o concreto fresco o danificasse. Todo este procedimento requer muito cuidado e atenção, pois o diâmetro da barra, mesmo com o extensômetro colado e isolado, não pode ultrapassar o diâmetro do furo, que é de $19 \mathrm{~mm}$;

- Deformações nas chapas de topo ou chapa passante para acompanhamento da plastificação e controle das deformações para comparações com os resultados numéricos;

- Deslocamentos verticais das vigas para observação da rotação e curvatura delas, bem como da rigidez do conjunto viga-pilar por meio das curvas forçadeslocamento. Os deslocamentos verticais foram medidos por oito transdutores de deslocamento (T1 a T8), conforme ilustrados na Figura 4.12;

- Rotação da viga nas proximidades da chapa de topo por meio de inclinômetro. A rotação da ligação foi medida por meio de três inclinômetros (I1, I2 e I3). 
Figura 4.11 - Detalhes da instrumentação dos modelos.

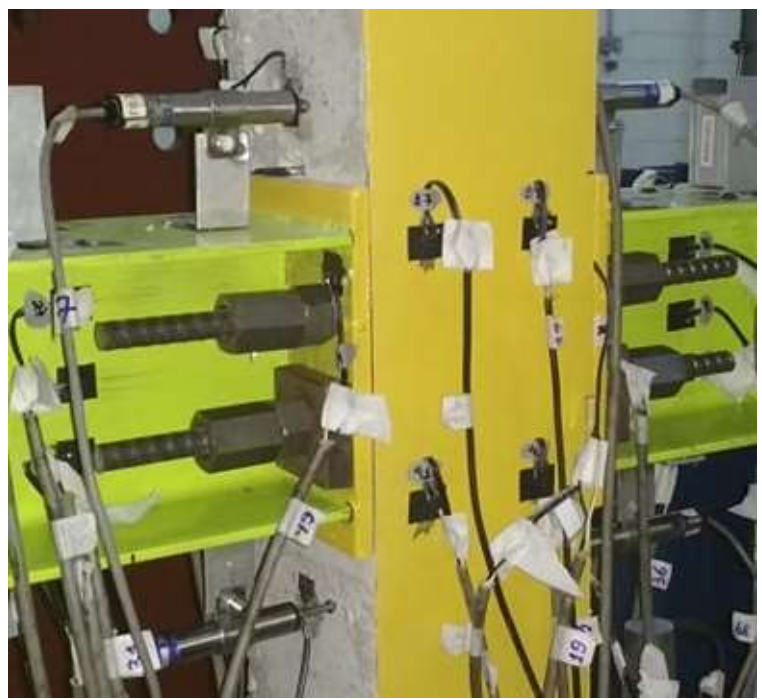

a) Instrumentação da Tipologia 1

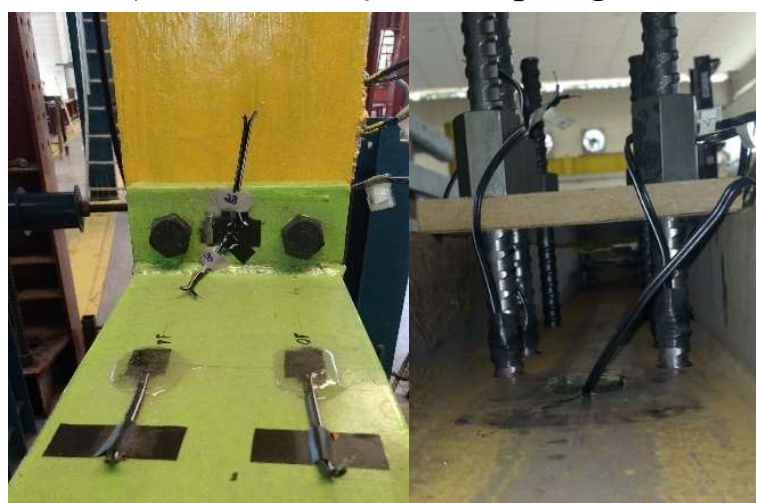

c) Instrumentação da ligação da Tipologia 3

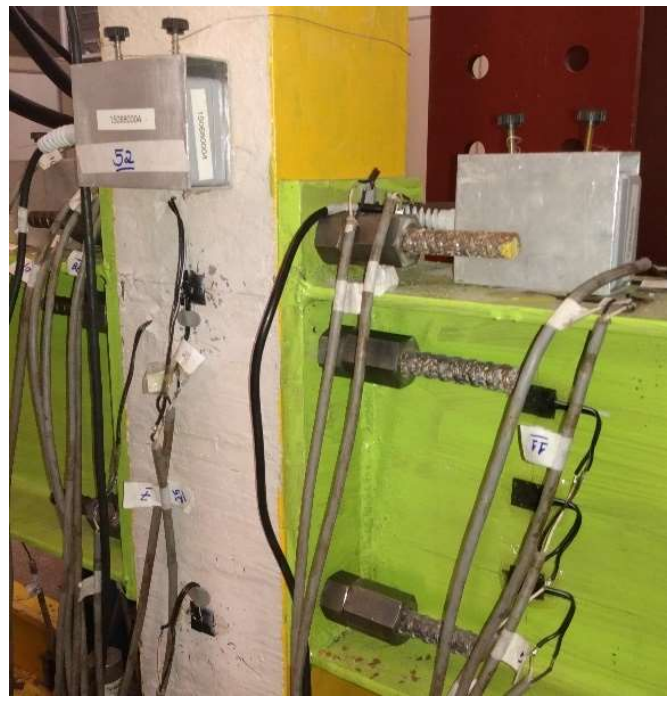

e) Instrumentação da Tipologia 4 Fonte: Elaborado pela autora.

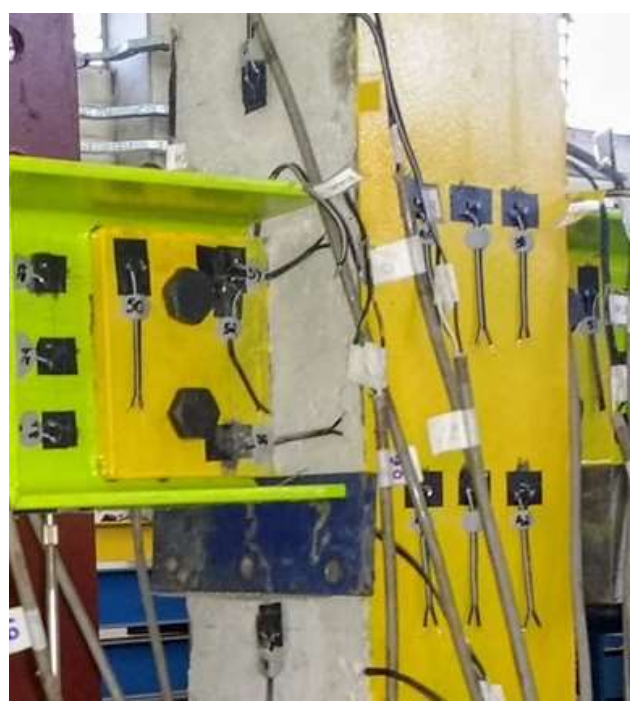

b) Instrumentação da Tipologia 2

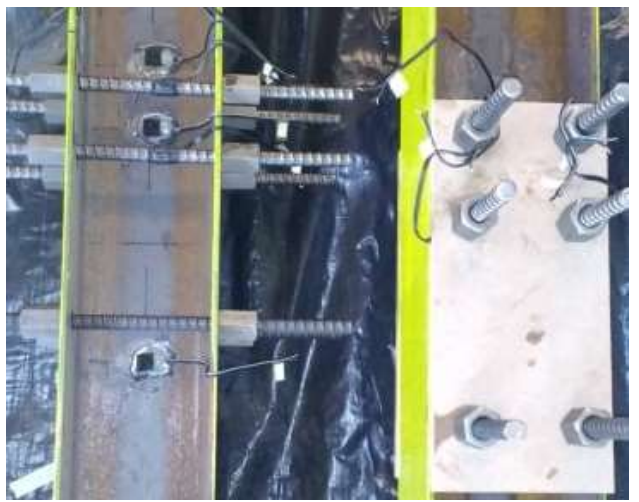

d) Instrumentação antes da concretagem

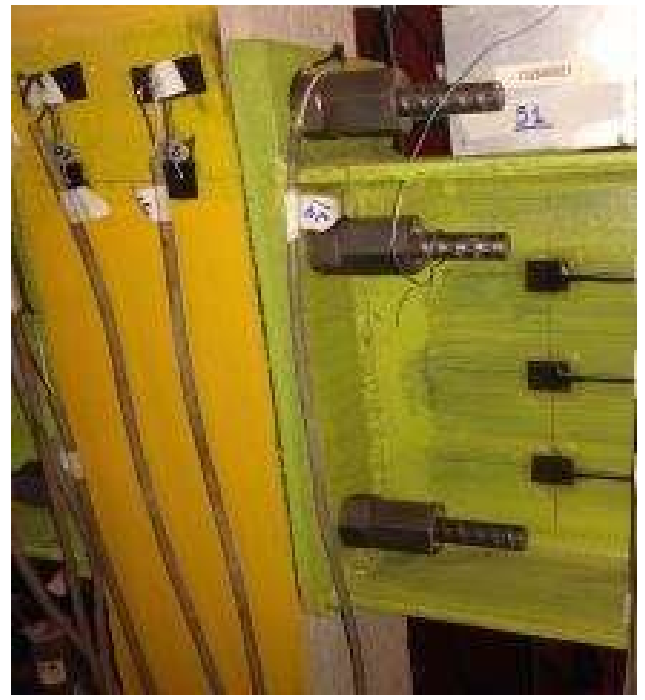

f) Instrumentação das Tipologias 5 e 6 
Figura 4.12 - Localização dos transdutores de deslocamento e inclinômetros.

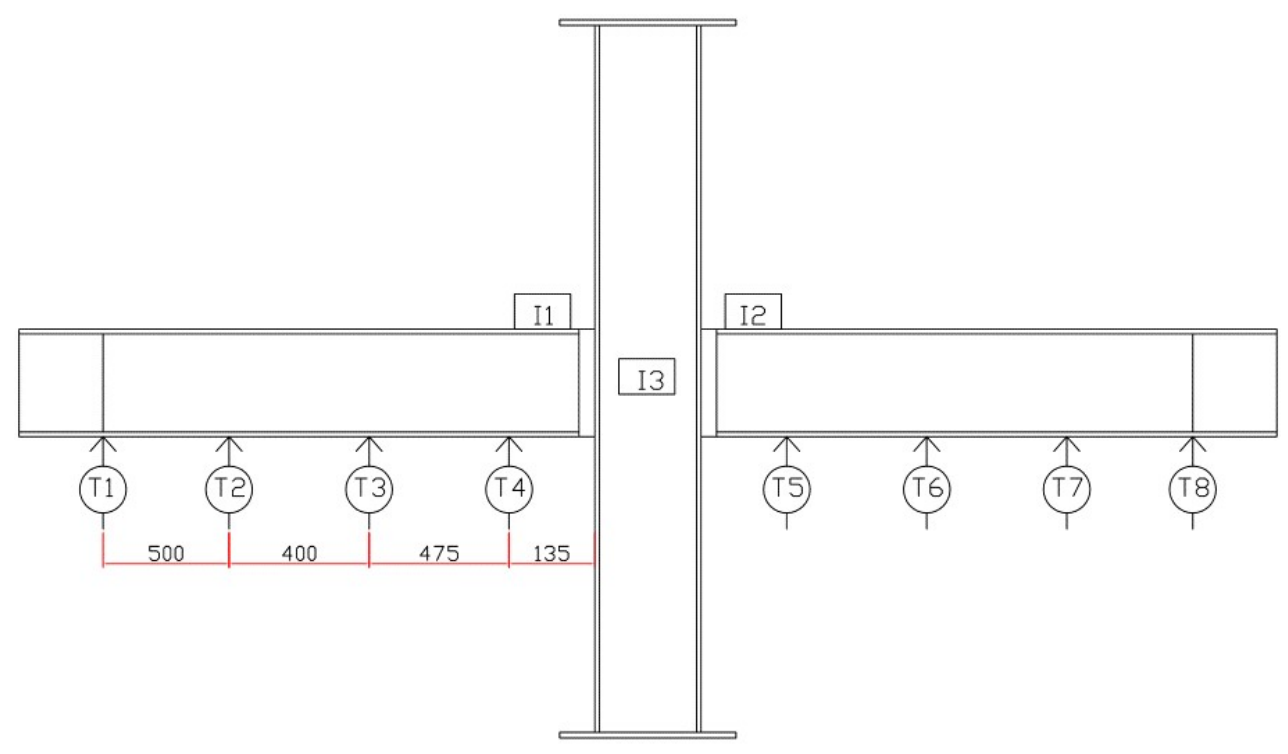

Fonte: Elaborado pela autora.

Cada tipologia apresenta particularidades na instrumentação e, por isso, cada uma é apresentada detalhadamente a seguir. Para o registro das deformações decorrentes da aplicação dos carregamentos, foram utilizados extensômetros elétricos dispostos nas vigas, pilar parcialmente revestido, chapa de topo e barras passantes, ou chapas passantes. A localização destes extensômetros é mostrada nas Figuras 4.13, 4.14, 4.15 e 4.16. 
Figura 4.13 - Localização dos extensômetros na tipologia 1.

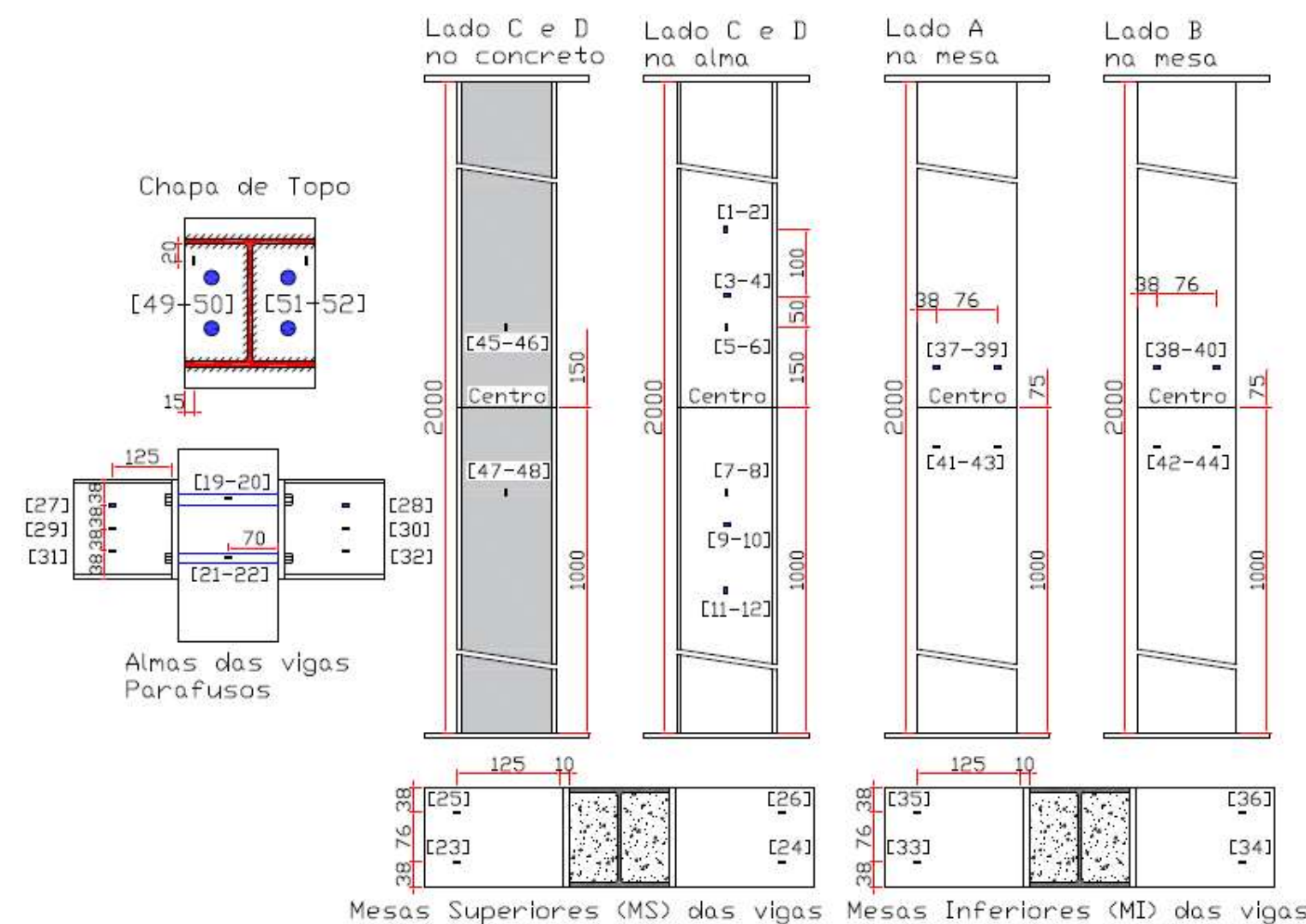

Fonte: Elaborado pela autora.

Mesas Inferiores (MI) das vigas

Figura 4.14 - Localização dos extensômetros na tipologia 2 (mm).

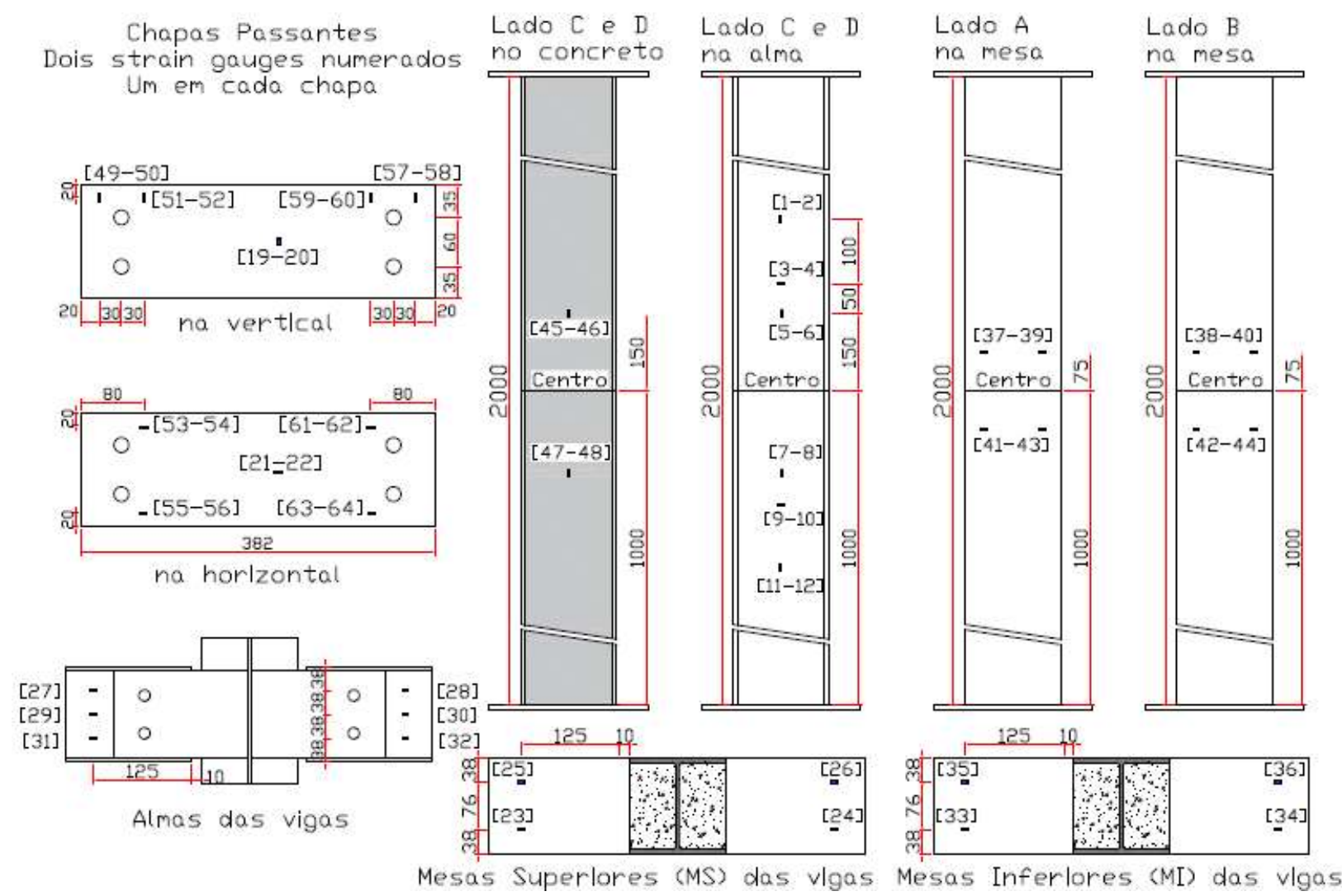

Fonte: Elaborado pela autora. 
Figura 4.15 - Localização dos extensômetros nas tipologias 3 e 4 (mm).

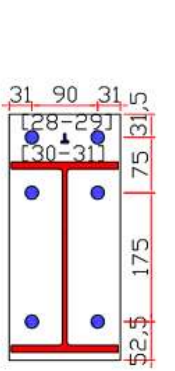

Chapa de Topo

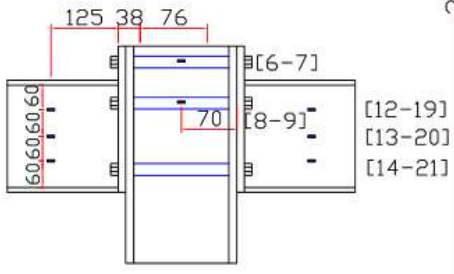

Almas das vigas Parafusos

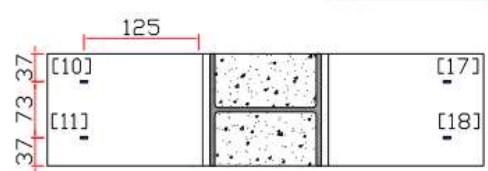

Mesas Superiores (MS) das vigas

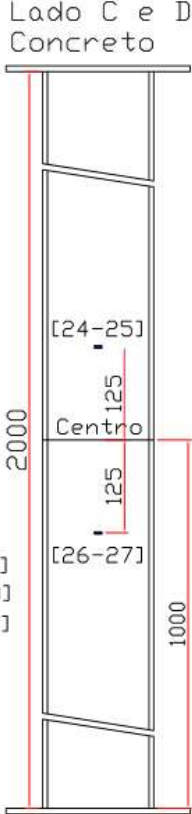
Ligação na mesa

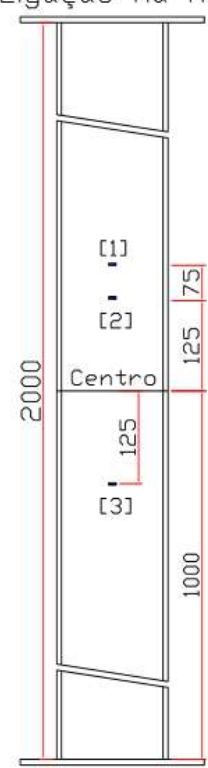

ado $A$ e B

Ligação na mesa

Fonte: Elaborado pela autora.

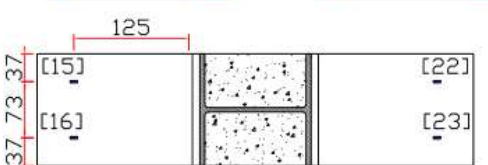

Mesas Inferiores (MI) das vigas

Figura 4.16 - Localização dos extensômetros nas tipologias 5 e 6 (mm).

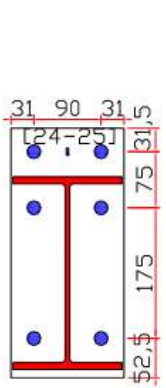

Chapa de Topo

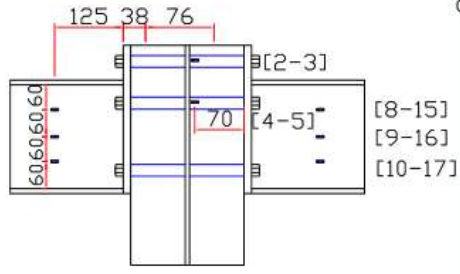

Almas das vigas Parafusos

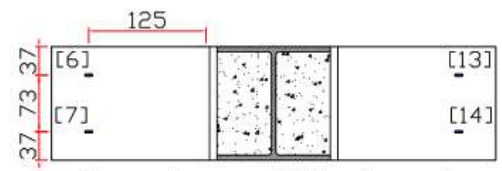

Mesas Superiores (MS) das vigas

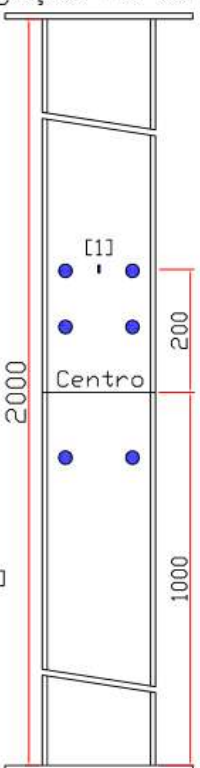

Lado B Ligação na alma Ligação na alma Ligação na alm
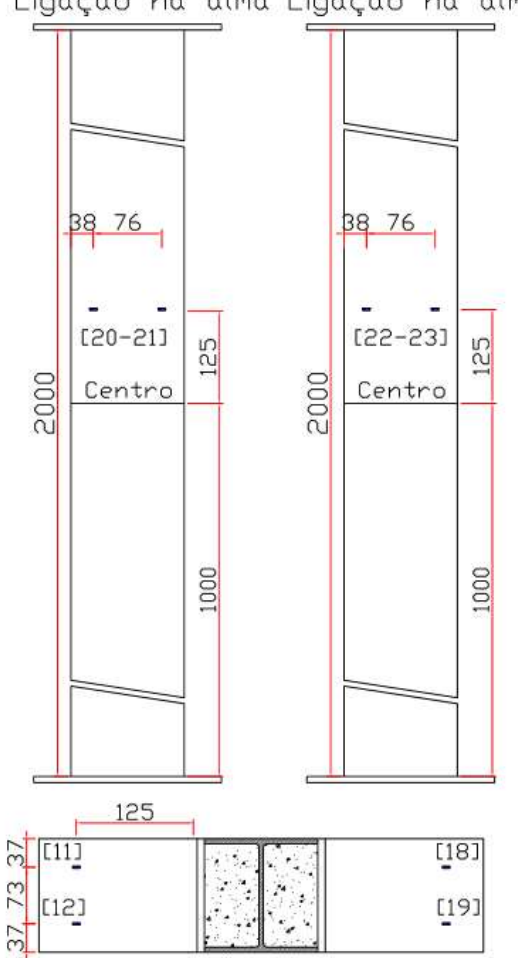

Mesas Inferiores (MI) das vigas

Fonte: Elaborado pela autora. 


\subsubsection{Esquema de Ensaio}

Os seis modelos de ligação ensaiados foram submetidos a um carregamento constante aplicado no pilar parcialmente revestido e a dois carregamentos variáveis aplicados nas extremidades das vigas de aço. Nos pilares parcialmente revestidos foi aplicada uma força axial de compressão, uniformemente distribuída em toda seção transversal mista, correspondente a cerca de $25 \%$ da sua capacidade resistente à compressão simples, ou seja, $400 \mathrm{kN}$. Para aplicar a força de compressão no pilar misto foi utilizado uma célula de carga com capacidade de 500 kN e um cilindro hidráulico de igual capacidade. O pilar ficou submetido a este carregamento constante durante todo o ensaio para gerar o mesmo efeito dos esforços provenientes dos pavimentos superiores de um edifício.

Cada uma das vigas foi submetida à aplicação de uma força vertical, aplicada com atuador servo-hidráulico, utilizando controle de deslocamento e de velocidade. Cada um dos atuadores tem capacidade de $500 \mathrm{kN}$ e os valores de deformação e deslocamento foram registrados por um sistema de aquisição de dados para extensometria, com capacidade de 90 canais, marca Measurements Group e modelo System 5000. O esquema de ensaio utilizado é ilustrado na Figura 4.17 e a visão geral do modelo na Figura 4.18. Neste esquema, foram utilizados 3 pórticos de reação com capacidade de $500 \mathrm{kN}$. No pórtico central foi colocado o cilindro hidráulico e célula de carga para o carregamento do pilar. Nos outros dois pórticos foram posicionados os atuadores servo-controlados para o carregamento das vigas. O pilar era simplesmente apoiado e as vigas eram impedidas de se deslocarem lateralmente.

Figura 4.17 - Esquema de ensaio das tipologias.

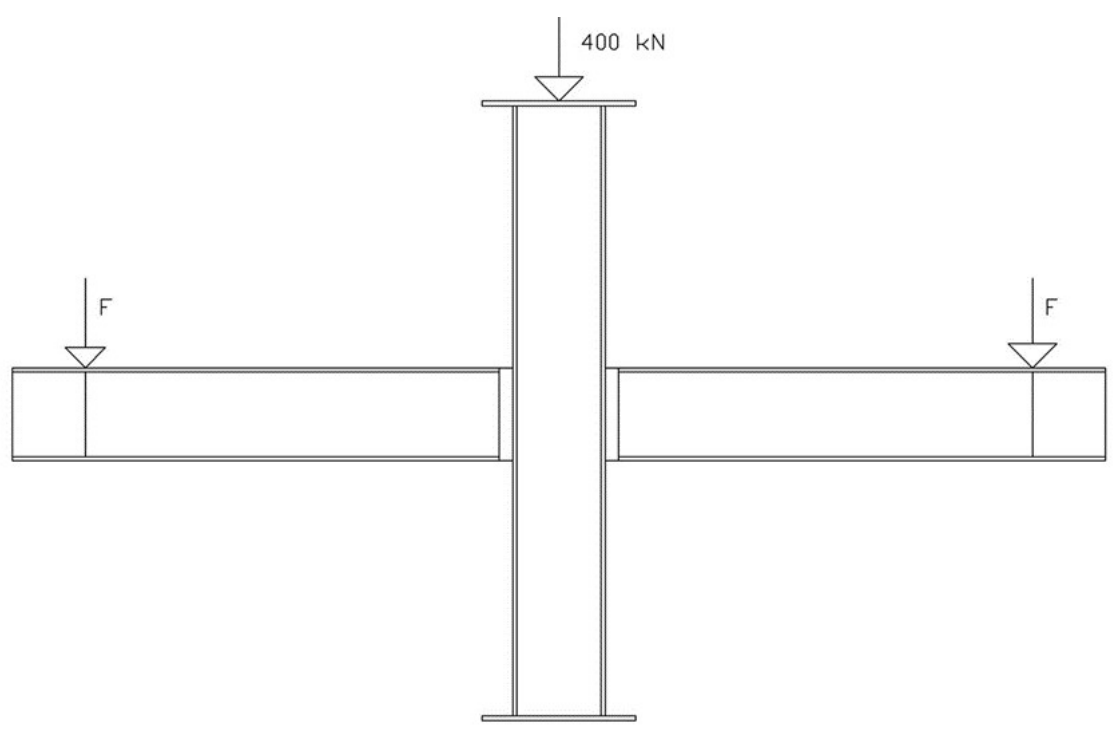

Fonte: Elaborado pela autora. 
Figura 4.18 - Visão geral do modelo instrumentado.

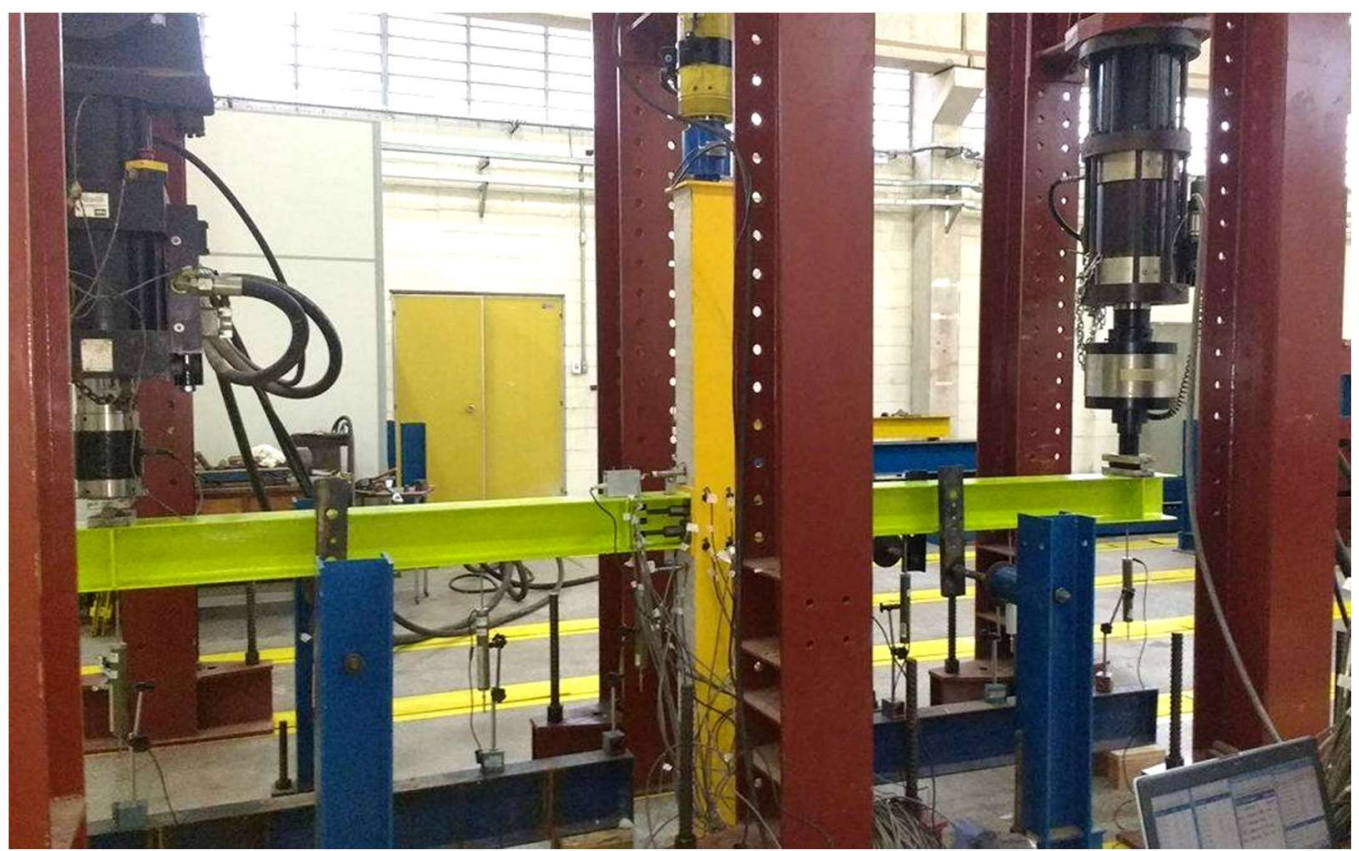

Fonte: Elaborado pela autora.

Como critérios para o colapso da ligação foram adotados a ruptura dos parafusos de qualquer um dos lados da ligação ou da solda, plastificação ou deslocamentos excessivos do pilar, chapas de topo ou vigas que fossem julgados prejudiciais aos equipamentos utilizados e à segurança do ensaio.

\subsection{Resultados}

\subsubsection{Propriedades Mecânicas dos Materiais que Compõem os Modelos Pilotos}

Algumas das principais propriedades mecânicas dos materiais necessárias ao estudo das tipologias de ligação foram determinadas experimentalmente. Corpos de prova cilíndricos de (10x20) $\mathrm{cm}$ foram moldados do concreto de revestimento dos pilares. Amostras de aço dos perfis do pilar e da viga, das barras passantes, da chapa passante e da chapa de topo foram ensaiadas à tração. Os principais valores médios de resistência à compressão e à tração, acompanhados do seu módulo de Young, são apresentados na Tabela 4.3. Ensaios não destrutivos foram realizados utilizando os equipamentos da Sonelastic ${ }^{\circledR}$, nos quais foi possível avaliar o módulo de elasticidade dinâmico do concreto e a partir deste estimar o módulo estático 
como $80 \%$ desse valor. A resistência à tração $\left(f_{u b}\right)$ dos parafusos de alta resistência não foi determinada experimentalmente, pois não havia equipamento que viabilizasse o ensaio do corpo de prova sem usinagem. A resistência adotada foi fornecida pelos fabricantes.

Tabela 4.3 - Propriedades dos materiais componentes dos elementos mistos ensaiados.

Fonte: Elaborado pela autora.

\begin{tabular}{c|c|c|c}
\hline Ligação & $\mathbf{f}_{\mathbf{y}} \mathbf{( M P a )}$ & $\left.\mathbf{f}_{\mathbf{u}} \mathbf{( M P a}\right)$ & Módulo de Young (GPa) \\
\hline Mesa & 380 & 495 & 200 \\
\hline Alma & 380 & 505 & 200 \\
\hline Chapa & 345 & 455 & 200 \\
\hline Barra & 900 & 1170 & 200 \\
\hline Armadura & 520 & 750 & 200 \\
\hline Estribo & 640 & 735 & 200 \\
\hline Parafuso & 650 & 850 & 200 \\
\hline & $\mathbf{f}_{\mathbf{c m}} \mathbf{( M P a )}$ & $\mathbf{f}_{\mathrm{tm}} \mathbf{( M P a )}$ & Módulo de Young (GPa) \\
\hline Concreto & 32 & 2,55 & 26,4 \\
\hline
\end{tabular}

\subsubsection{Capacidade Resistente, Deslocamentos e Deformações dos Modelos Pilotos}

Neste item são apresentados os resultados obtidos na experimentação física das tipologias de ligação estudadas, ressaltando a distribuição de deformações, comportamento dos materiais presentes na ligação, deslocamentos e comportamento Momento x Rotação.

\section{a) Capacidade Resistente}

Neste item, são apresentados os resultados decorrentes da experimentação física das Tipologias 1 e 2, cujo objetivo era determinar um tipo de ligação e instrumentação para os ensaios definitivos, constituídas por chapas de topo e barras passantes, e chapas passantes, respectivamente. Na Figura 4.19 é apresentada a variação da força vertical em cada atuador em função do deslocamento vertical destes e, os valores médios. Os dois atuadores mantiveram uma certa simetria no carregamento ao longo dos ensaios, logo as análises posteriores podem ser realizadas com a força média.

Os valores médios de força última aplicada em cada tipologia de ligação são apresentados na Tabela 4.4 juntamente com os valores de momento último calculados em função da força última e do braço de alavanca. Observa-se que além das forças verticais aplicadas na extremidade de cada uma das vigas, foi aplicada uma força axial de compressão de $400 \mathrm{kN}$ sobre o pilar parcialmente revestido. 
Tabela 4.4 - Valores médios de força última e momento resistente.

\begin{tabular}{|c|c|c|c|}
\hline Modelo & Força Última (kN) & Momento Último (kN.m) & Deslocamento (mm) \\
\hline Tipologia 1 & 17,25 & 26,05 & 70,77 \\
\hline Tipologia 2 & 12,80 & 19,30 & 112,20 \\
\hline
\end{tabular}

Fonte: Elaborado pela autora.

Figura 4.19 - Força vertical em cada viga x deslocamento vertical do atuador.

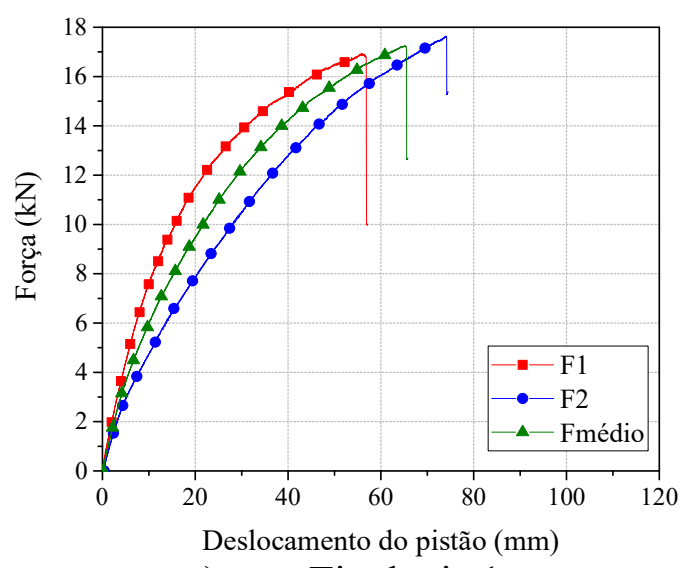

a) Tipologia 1

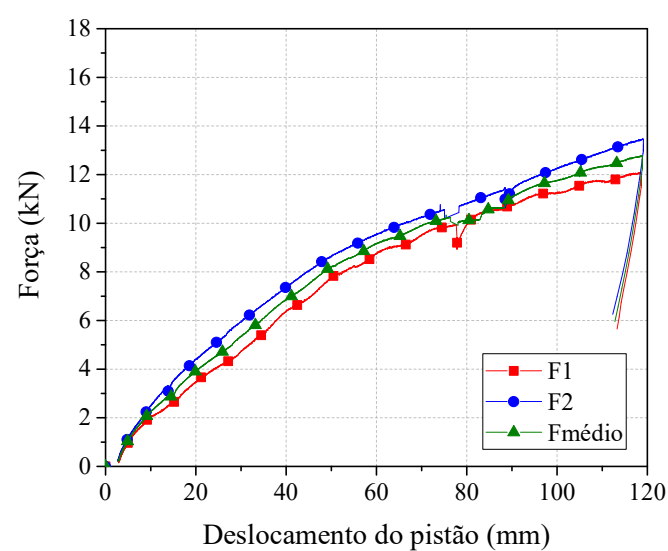

b) Tipologia 2

Fonte: Elaborado pela autora.

\section{b) Deslocamentos Verticais}

Os deslocamentos verticais medidos por transdutores de deslocamento em diversos pontos ao longo das vigas são apresentados na Figura 4.20. Os valores de deslocamento vertical são muito coerentes com as posições dos transdutores, podendo ser constatado que o deslocamento próximo da região de ligação é próximo a zero (ponto T4-T5).

Figura 4.20 - Deslocamento vertical das vigas.

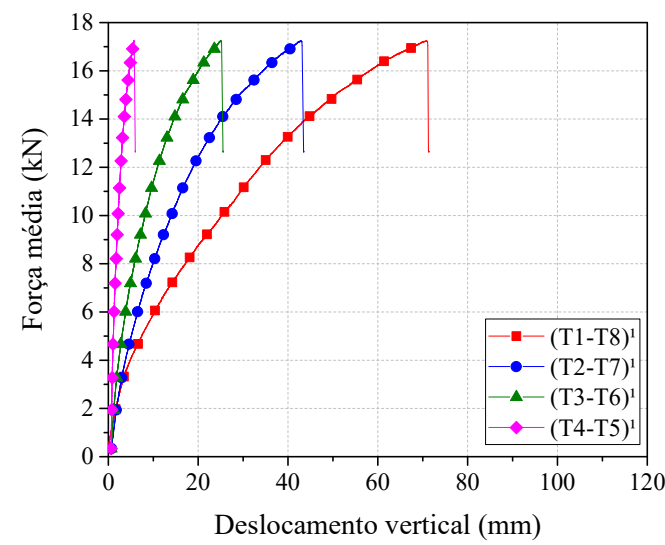

a) Tipologia 1

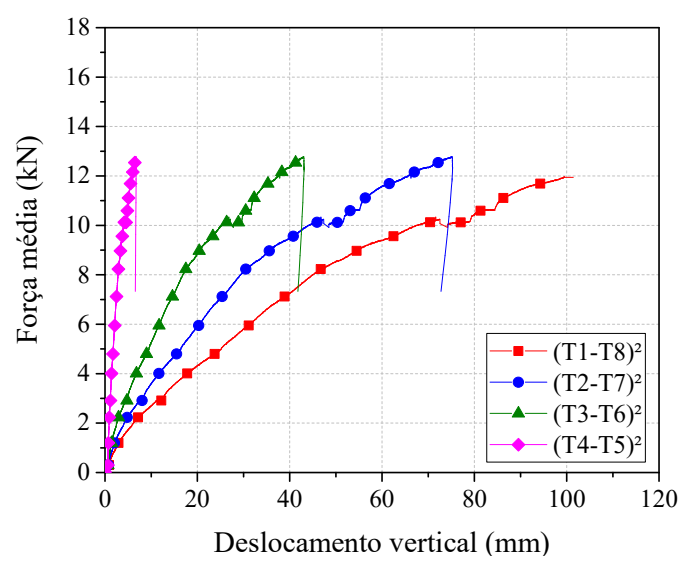

b) Tipologia 2

Fonte: Elaborado pela autora. 
Pôde-se constatar que para o mesmo tipo de pilar misto e viga de aço, a ligação com chapa de topo e barras passantes (Tipologia 1) é mais rígida que a ligação com chapas passantes (Tipologia 2), que se assemelha a ligação por cantoneiras de alma. Contudo, chapas de contato foram colocadas na região comprimida da tipologia 2 (chapa azul - Figura 4.21). Tais chapas permitiram certa transferência dos esforços de compressão das mesas inferiores das vigas para o pilar parcialmente revestido. Sem as chapas de transferência, as extremidades das vigas apresentariam maiores ganhos de deslocamento vertical, sem acréscimo na força aplicada; isto porque não há um dispositivo mecânico para transferência das forças de compressão, da viga para o pilar.

Figura 4.21 - Chapa de contato na região comprimida entre a viga e o pilar misto.

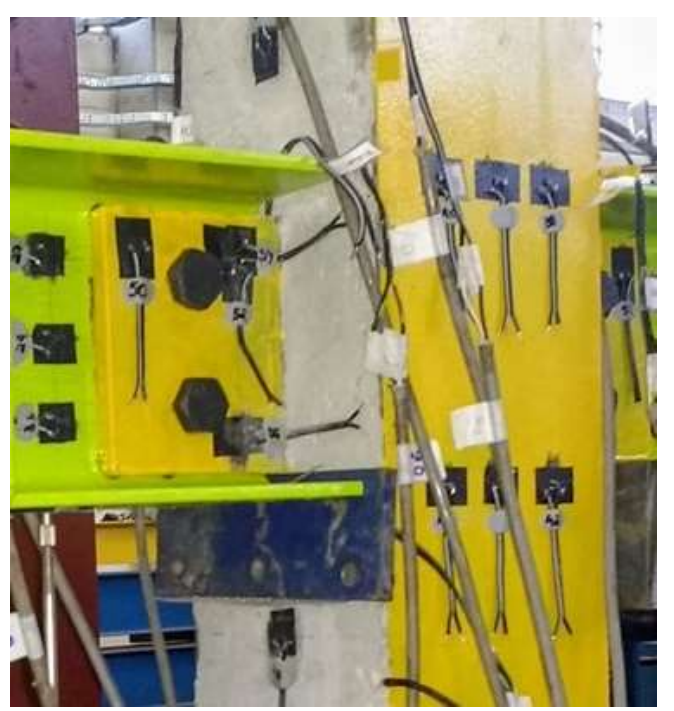

Fonte: Elaborado pela autora.

\section{c) Configuração de Ruína}

Na Tipologia 1, o modo de falha foi o escoamento da chapa de topo da ligação vigapilar e a ruptura parcial da solda da chapa de topo, como pode ser visto na Figura 4.22. Conforme foi visto no trabalho de Ataei et al (2017), quando mantem a espessura da chapa de topo menor que $60 \%$ da dimensão do diâmetro do parafuso, ocorre um modo de falha dúctil com o escoamento da chapa de topo. Na Tipologia 1, a proporção entre a espessura da chapa de topo e o diâmetro das barras passantes era de $67 \%$ e houve o escoamento da chapa de topo. 
Figura 4.22 - Configuração final da tipologia 1.

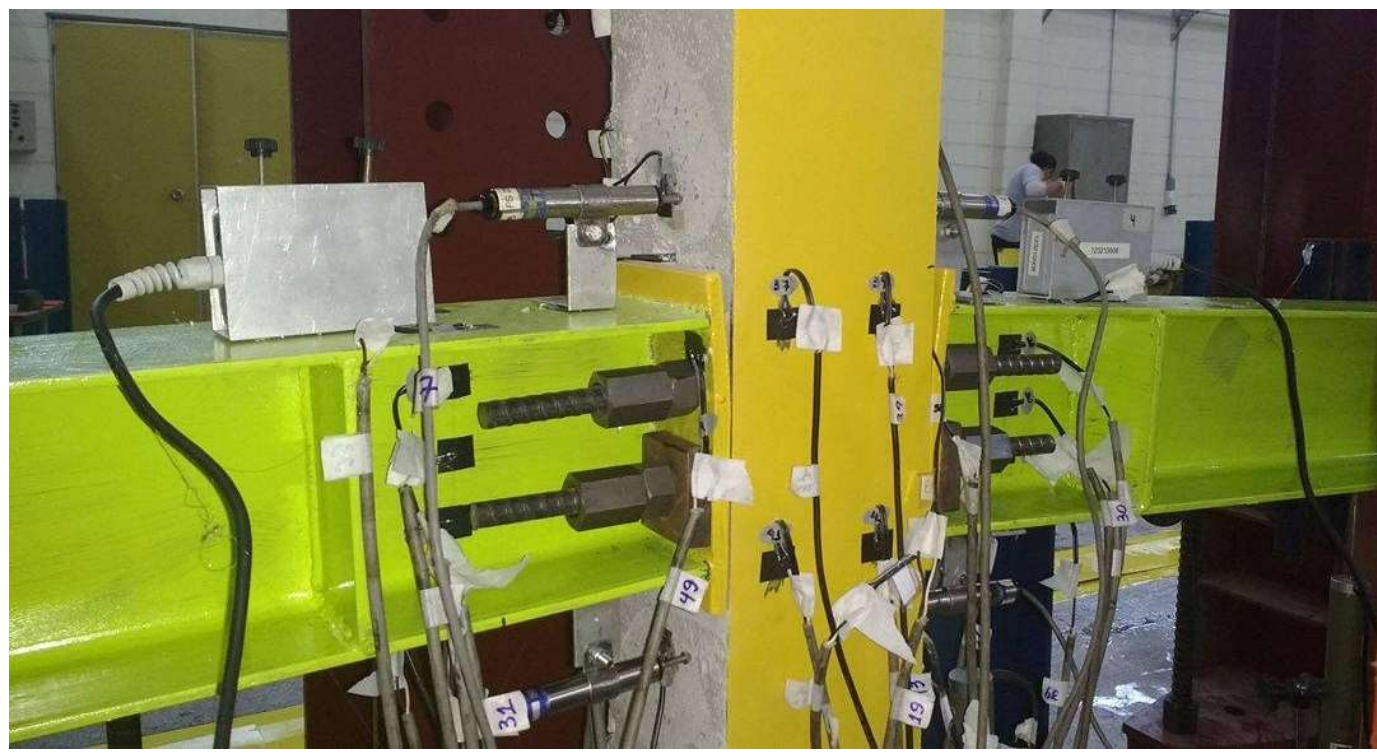

a) Configuração da ligação

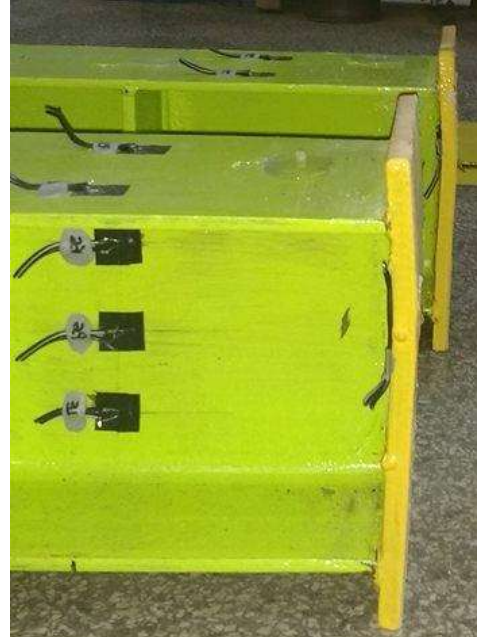

b) Configuração da chapa Fonte: Elaborado pela autora.

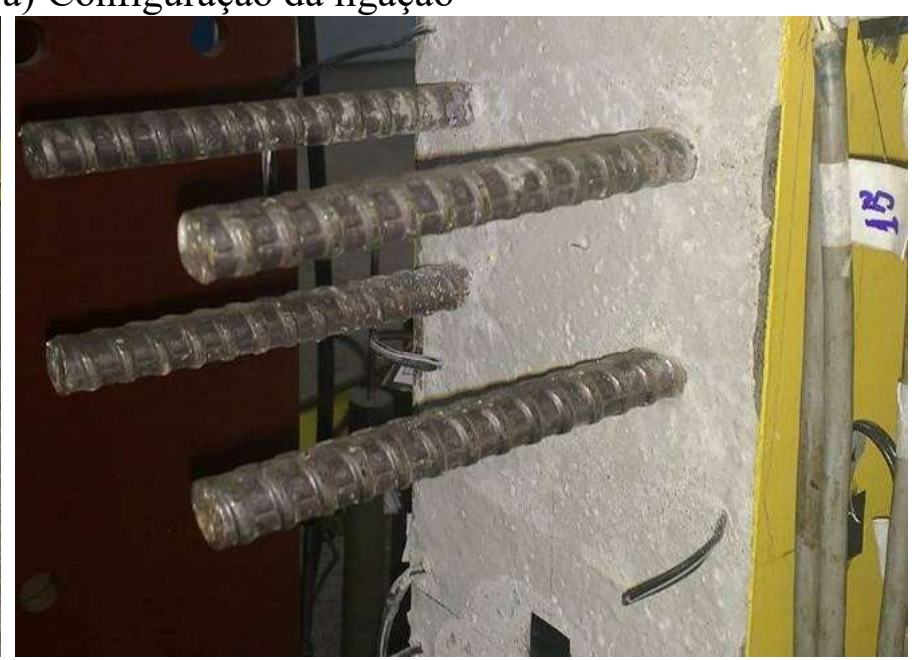

c) Configuração da barra passante

A Tipologia 2 não atingiu o colapso e seu comportamento foi caracterizado por rotação excessiva da ligação, uma vez que tal detalhe apresentou comportamento muito semelhante ao de uma rótula, ou seja, sem significativa capacidade de transmitir momento fletor da viga para o pilar parcialmente revestido (Figura 4.23). A ausência de deformações significativas permitiu avaliar a influência de chapas de contato posicionadas no espaço existente entre a mesa inferior das vigas e a face externa do pilar parcialmente revestido. Estas chapas permitiram a transferência de parte das forças de compressão da mesa inferior das vigas para o pilar misto, desde o início da aplicação dos carregamentos nas vigas. Observa-se também o esmagamento dos furos na alma das vigas. 
Figura 4.23 - Configuração final da tipologia 2.

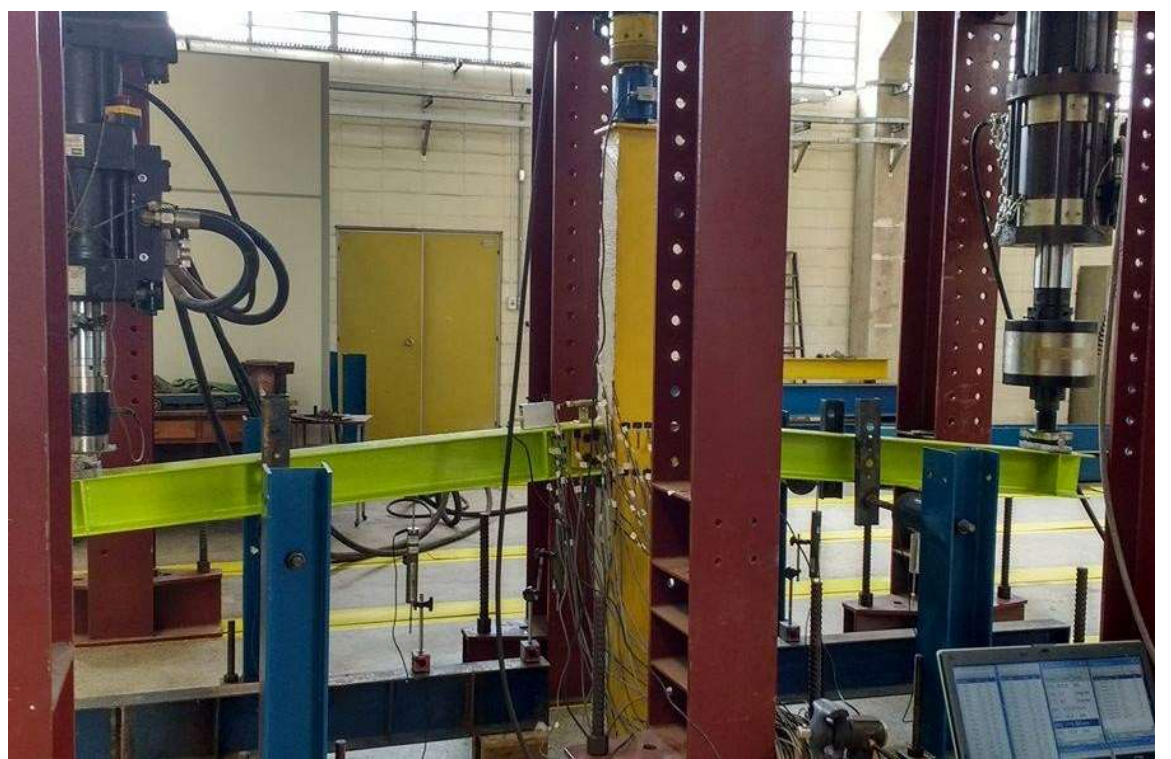

a) Configuração da ligação

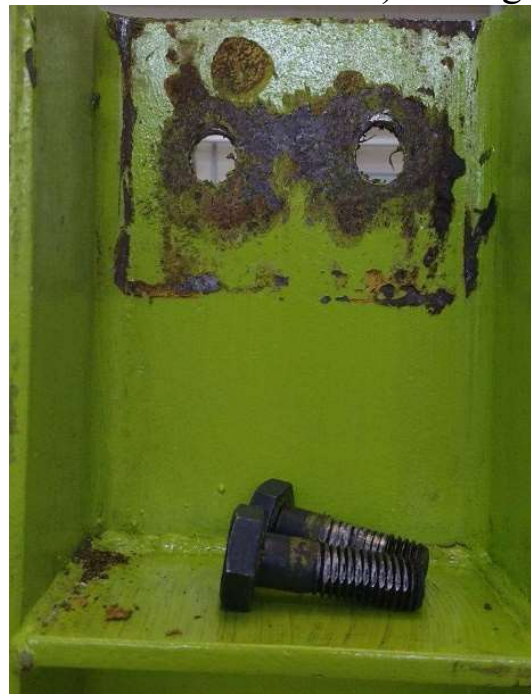

b) Configuração do furo e parafuso

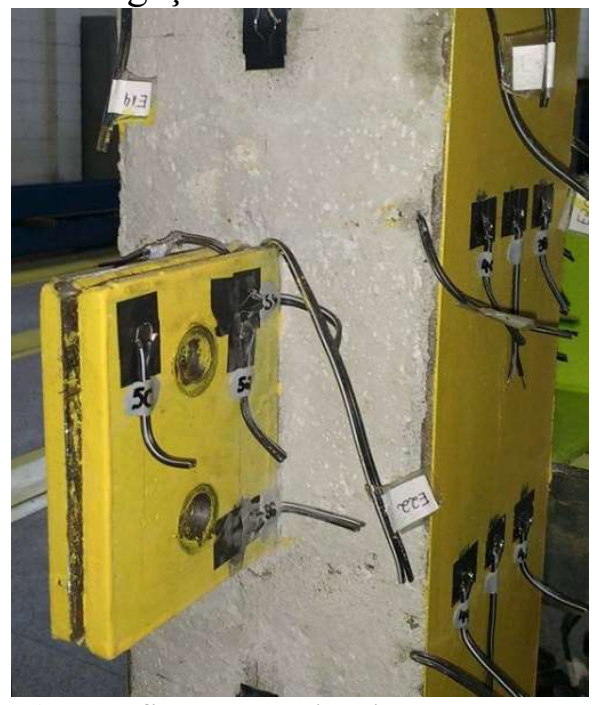

c) Configuração da chapa passante Fonte: Elaborado pela autora.

\section{d) Deformação Axial das Barras Passantes e Chapa de Topo}

Os extensômetros elétricos colados no centro de cada uma das barras passantes permitiram acompanhar a evolução das deformações axiais nestes elementos. Os resultados de força vertical média x deformação são apresentados na Figura 4.24. As deformações nas barras passantes são mais significativas naquelas posicionadas na linha superior (região tracionada). Neste sentido, as deformações nas barras 19 e 20 apresentaram pequenas variações na ordem de grandeza das deformações, sendo utilizada a média desses valores, assim como nos 
extensômetros posicionados na mesma direção (21-22, 49-50 e 51-52). Esta diferença pode ter sido devido a imperfeições geométricas.

Figura 4.24 - Deformações na chapa de topo (49-52) e nas barras passantes (19-22).
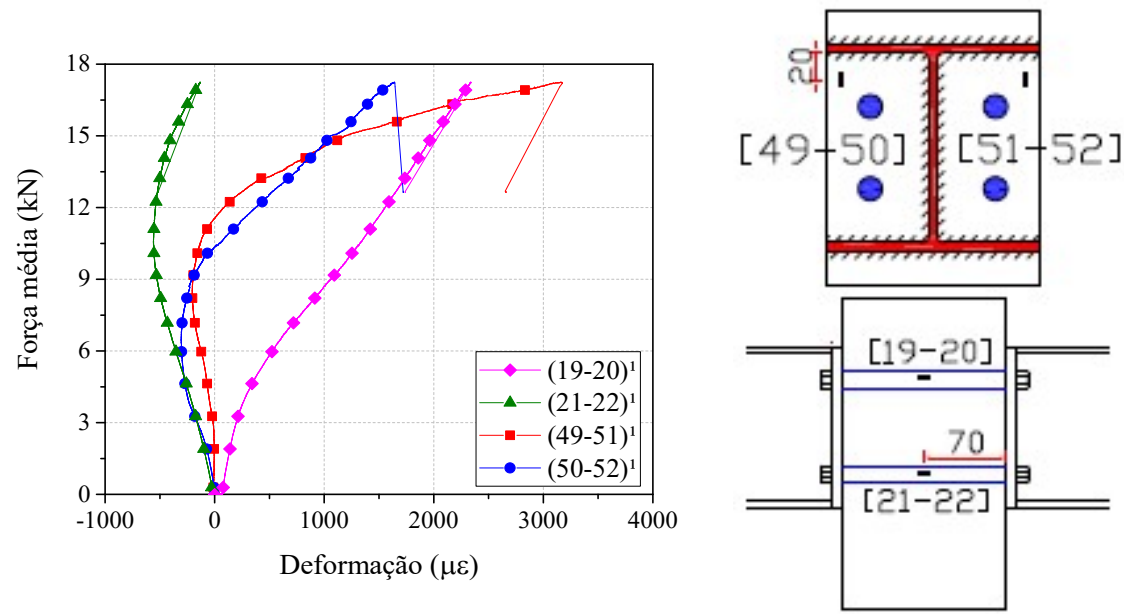

Fonte: Elaborado pela autora.

A instrumentação dos pontos permitiu acompanhar a evolução das deformações em cada uma das chapas de topo isoladamente. Sendo assim, o comportamento das deformações axiais das chapas esquerda e direita do pilar parcialmente revestido apresenta pequena variação um do outro. À direita do pilar [50-52] percebe-se que, até muito próximo da força última ser atingida, as deformações são menores. Em contrapartida, à esquerda do pilar misto [49-51], quando a força vertical nas vigas atinge aproximadamente $12 \mathrm{kN}$ começam a ocorrer deformações crescentes e maiores que os registrados na outra chapa, constatando o escoamento na chapa. Este comportamento diferenciado é ocasionado pela aderência entre as barras passantes e o núcleo de concreto do pilar parcialmente revestido que, durante o encaixe da porca e contra porca, impede que a força de aperto seja transferida por completo para a outra extremidade da ligação, podendo existir uma folga em um dos lados. Além disso, uma das superfícies de contato entre o concreto e a chapa de topo, não estava com perfeito acabamento, devido à dificuldade na hora da concretagem de manter as barras posicionadas para haver adesão ao concreto.

e) Deformação na Chapa Passante 
As deformações registradas são mostradas na Figura 4.25. Na chapa passante ocorreram deformações muito pequenas e inferiores àquelas correspondentes ao escoamento do aço. $\mathrm{Na}$ direção horizontal são registradas deformações mais significativas e que chegam próximas a 1\%o, indicando que nesta direção a chapa passante é mais solicitada. Entretanto, os extensômetros [57-58] na direção vertical apresentaram uma deformação maior que a dos demais nessa direção, devido ao grande deslocamento vertical da viga de aço, ocasionando o contato da extremidade da chapa passante com mesa superior da viga.

Figura 4.25 - Deformações na chapa passante.
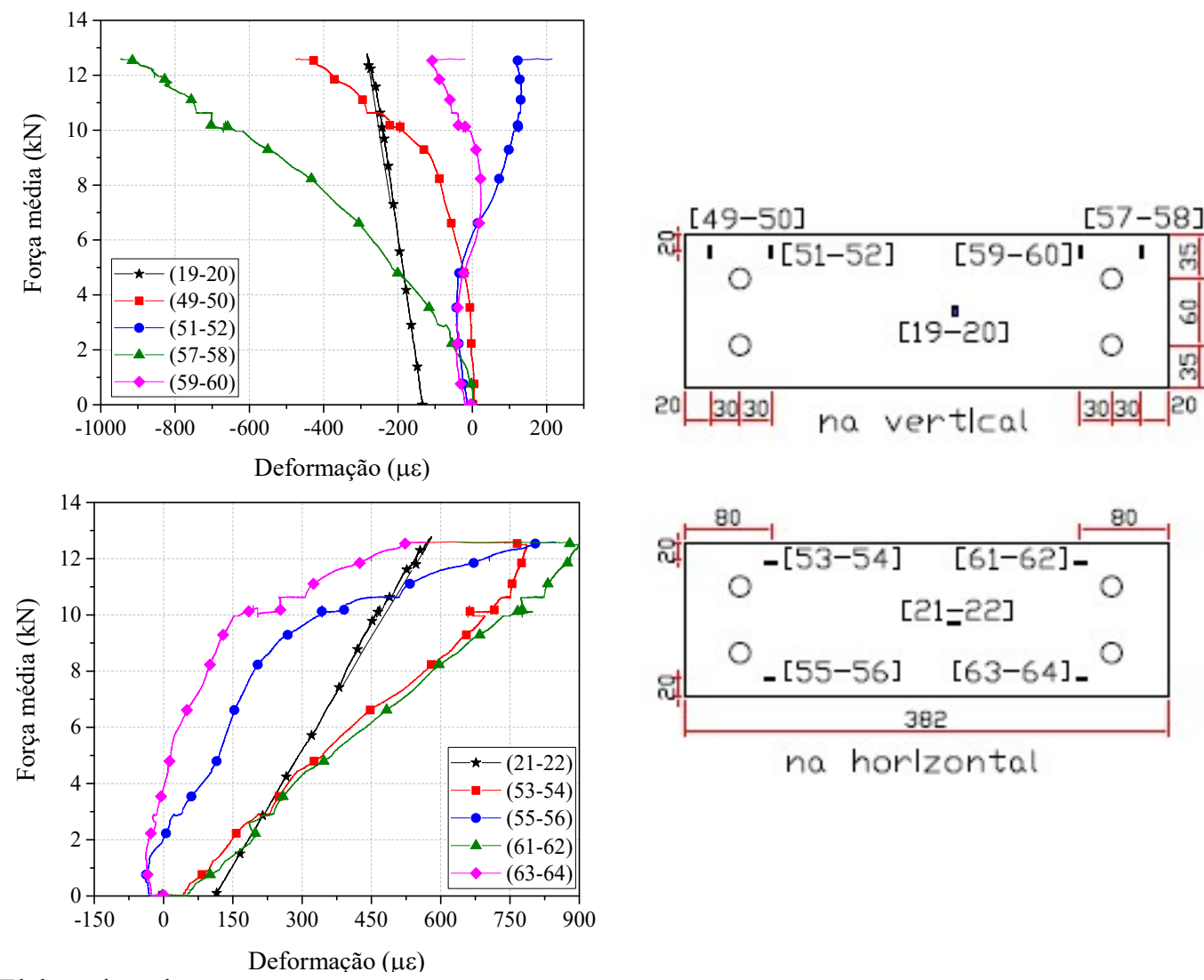

na horlzontal

Fonte: Elaborado pela autora.

\section{f) Deformação Axial das Vigas}

Na Figura 4.26 são apresentados os principais resultados de deformação registrados nas mesas e almas das vigas direita e esquerda das Tipologias 1 e 2. Os valores de deformação foram pequenos e não ultrapassaram 1 \%o, não chegaram a atingir os valores correspondentes ao escoamento do aço. Comparando as deformações nas almas para as Tipologias 1 e 2 se verifica que na Tipologia 1 a linha neutra encontra-se na posição esperada próxima a H/2 ao passo que, na Tipologia 2, encontra-se abaixo de H/2. A distribuição de deformações nas almas 
das vigas da Tipologia 2 levou a concluir que a linha neutra havia se deslocado em relação a $\mathrm{H} / 2$ devido à diferença de rigidez entre as regiões tracionada e comprimida proporcionada pelas chapas de contato. Além disso, a deformação da mesa superior é menor que da alma, o que indica o contato entre a mesa superior e a chapa passante e o esmagamento dos furos. $\mathrm{Na}$ Tipologia 1, a linha neutra encontra-se próxima a $\mathrm{H} / 2$; isto significa que a aderência entre as barras passantes e o concreto de revestimento do pilar misto, e o núcleo de concreto na região comprimida, contribuiu para "equilibrar" a rigidez entre as porções tracionada e comprimida.

Figura 4.26 - Deformações nas vigas.

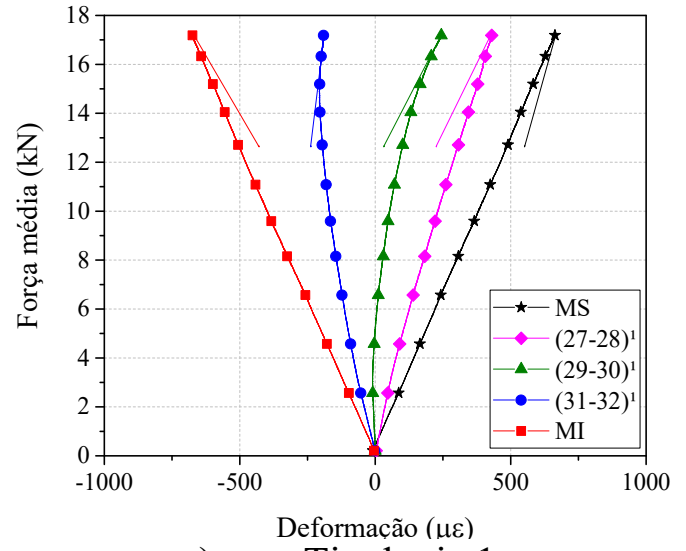

a) Tipologia 1

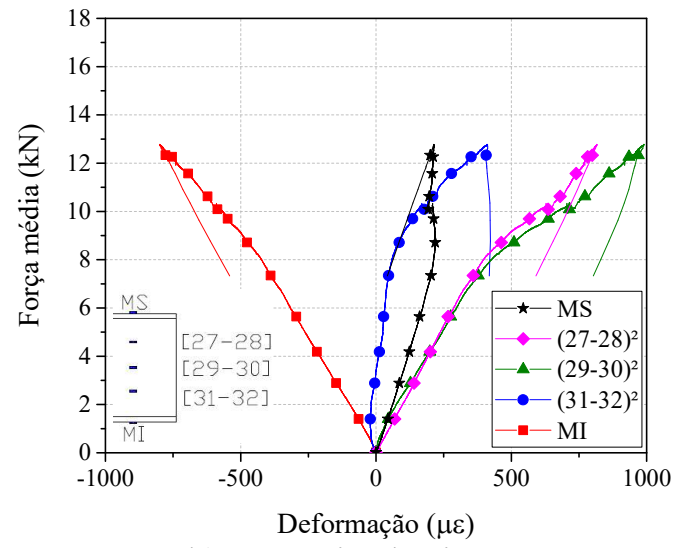

b) Tipologia 2

Fonte: Elaborado pela autora.

\section{g) Rotação Absoluta da Ligação}

Para avaliar a rotação absoluta da ligação foram utilizados inclinômetros nas vigas (Figura 4.27) e a classificação de ligações quanto à rigidez do EC3 (2005) para um vão de 150 $\mathrm{cm}$. A Tipologia 2 comporta-se como rotulada apresentando baixa capacidade de transmitir momento fletor e rotações acentuadas. Já a Tipologia 1 comporta-se como uma ligação com maior rigidez, semirrígida, onde há restrição parcial à rotação entre os elementos conectados.

Observou-se que a Tipologia 1 demonstrou um comportamento mais desejado para análises futuras do que a Tipologia 2, apresentando maior rigidez e capacidade resistente, menor capacidade rotacional e um modo de ruptura devido à ligação da chapa de topo com as mesas das vigas. A solução para Tipologia 2 seria aumentar a altura das vigas e acrescentar cantoneiras de assento, além disso, poderia torná-la uma ligação mista com adição de uma laje, que não era possível nesse estudo. Percebeu-se que os outros pontos instrumentados não continham informações relevantes e serão descartados nos ensaios definitivos. A partir do ensaio piloto, foi feita uma previsão teórica da capacidade resistente dos ensaios definitivos (Anexo A). 
Figura 4.27 - Rotação absoluta média da ligação.

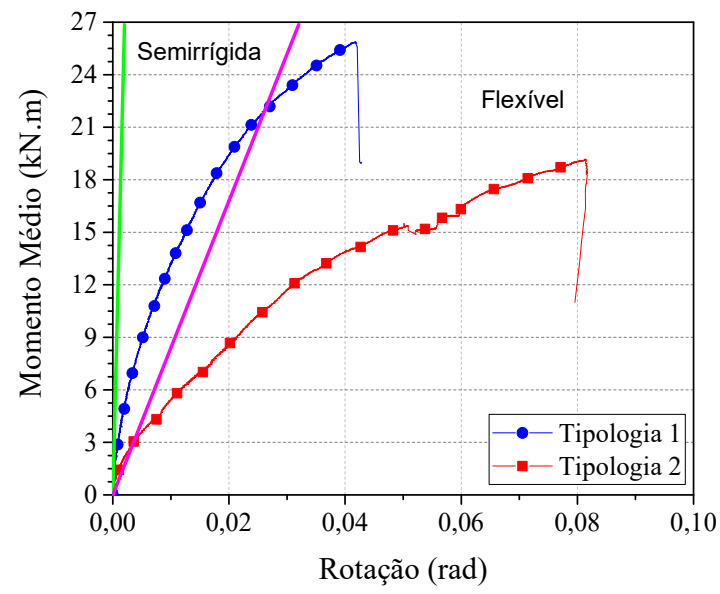

Fonte: Elaborado pela autora.

\subsubsection{Propriedades Mecânicas dos Materiais que Compõem os Modelos Definitivos}

A determinação das propriedades dos materiais necessárias ao estudo dos ensaios definitivos foi realizada de acordo com a metodologia descrita no item 4.3.2. A seguir, são apresentados os valores médios obtidos no ensaio de caracterização, acompanhados do seu módulo de Young. Os valores médios de resistência à compressão do concreto, resistência à tração por compressão diametral e módulo de elasticidade longitudinal (obtido da curva tensão versus deformação) são dados na Tabela 4.5. Da mesma forma, os resultados médios da caracterização do aço das almas e mesas de pilares e vigas, das chapas de topo, das barras passantes e das armaduras são apresentados. $\mathrm{O}$ aço dos pilares, vigas e chapas de topo são do tipo ASTM A572 grau 50.

Tabela 4.5 - Propriedades dos materiais componentes dos elementos mistos ensaiados.

\begin{tabular}{|c|c|c|c|}
\hline Ligação & $\mathbf{f}_{\mathbf{y}}(\mathrm{MPa})$ & $\mathrm{fu}_{\mathrm{u}}(\mathrm{MPa})$ & Módulo de Young (GPa) \\
\hline Mesa Pilar & 375 & 515 & 200 \\
\hline Alma Pilar & 370 & 500 & 200 \\
\hline Mesa Viga & 365 & 510 & 200 \\
\hline Alma Viga & 385 & 520 & 200 \\
\hline Chapa de Topo & 415 & 555 & 200 \\
\hline Barra Passante & 900 & 1170 & 200 \\
\hline Armadura & 520 & 750 & 200 \\
\hline Estribo & 640 & 735 & 200 \\
\hline \multirow[t]{2}{*}{ Parafuso } & 650 & 850 & 200 \\
\hline & $\mathrm{f}_{\mathrm{cm}}(\mathrm{MPa})$ & $\mathbf{f}_{\mathrm{tm}}(\mathrm{MPa})$ & Módulo de Young (GPa) \\
\hline Concreto c/ fibras & 41 & 3,98 & 35 \\
\hline Concreto s/ fibras & 42,75 & 2,53 & 35 \\
\hline
\end{tabular}

Fonte: Elaborado pela autora. 


\subsubsection{Capacidade Resistente, Deslocamentos e Deformações dos Modelos Definitivos}

A partir da metodologia descrita no Capítulo 4, foi realizada a previsão teórica, e posteriormente a experimentação física, de quatro tipologias de ligação viga de aço-pilar parcialmente revestido, variando a presença do concreto na ligação e o eixo de inércia do pilar. Duas destas tipologias consistem em ligações com chapa de topo e barras passantes no eixo de maior momento de inércia do pilar, que diferem entre si apenas na aderência entre as barras e o núcleo de concreto do pilar parcialmente revestido. As duas tipologias restantes são ligações com chapa de topo e barras passantes no eixo de menor momento de inércia do pilar e a diferença entre ambas é a presença do concreto de revestimento na ligação. Primeiramente será discutido, de maneira geral, o comportamento de cada modelo durante o ensaio. Estas discussões são desenvolvidas conforme os resultados de capacidade resistente, deslocamentos, distribuição de deformações e rotação em cada ensaio vão sendo apresentados. No final, são feitas comparações entre os resultados dos modelos ensaiados.

\section{a) Capacidade Resistente}

Neste item, são apresentados os resultados decorrentes da experimentação física das Tipologias de 3 a 6 , constituídas por chapas de topo e barras passantes. Os valores de força última aplicada em cada tipologia de ligação são apresentados na Tabela 4.6 juntamente com os valores de momento último calculados em função da força última e do braço de alavanca.

Tabela 4.6 - Valores médios de força última e momento resistente.

\begin{tabular}{|c|c|c|c|}
\hline Modelo & Força Última (kN) & Momento Último (kN.m) & Deslocamento (mm) \\
\hline Tipologia 3 & 27,79 & 41,69 & 41,14 \\
\hline Tipologia 4 & 101,51 & 152,27 & 32,65 \\
\hline Tipologia 5 & 70,91 & 106,37 & 30,47 \\
\hline Tipologia 6 & 26,34 & 39,51 & 25,36 \\
\hline
\end{tabular}

Fonte: Elaborado pela autora.

Além das forças verticais em cada uma das vigas, há uma força axial de compressão de $400 \mathrm{kN}$ sobre o pilar misto. As forças últimas das Tipologias 3 e 4 no eixo de maior inércia do pilar foram próximas das previstas teoricamente no Anexo A. Já na Tipologia 5, a força última foi menor apesar do modo de ruptura ter sido igual ao previsto. Na Figura 4.28 é apresentada a variação da força vertical em cada atuador em função do deslocamento vertical destes e, os 
valores médios. Os dois atuadores mantiveram uma simetria no carregamento ao longo dos ensaios, logo as análises posteriores podem ser realizadas com a força média.

Figura 4.28 - Força vertical em cada viga x deslocamento vertical do atuador.

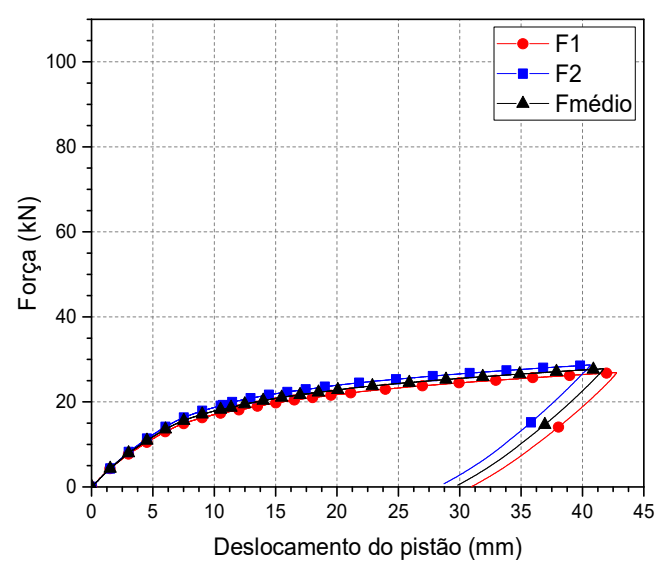

a) Tipologia 3

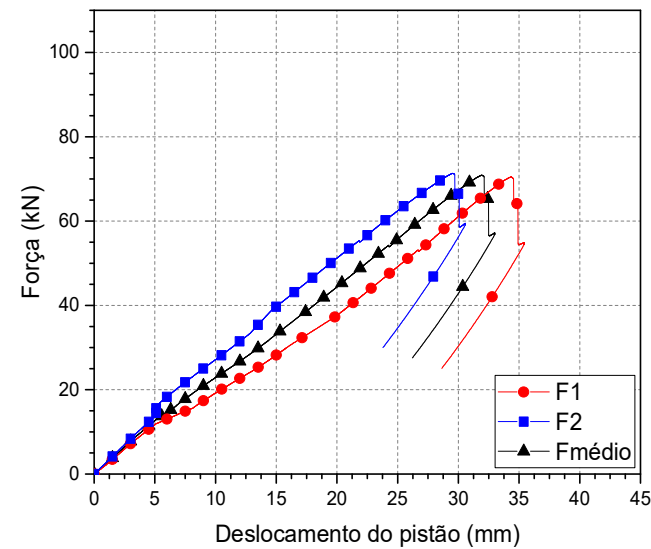

c)

Tipologia 5

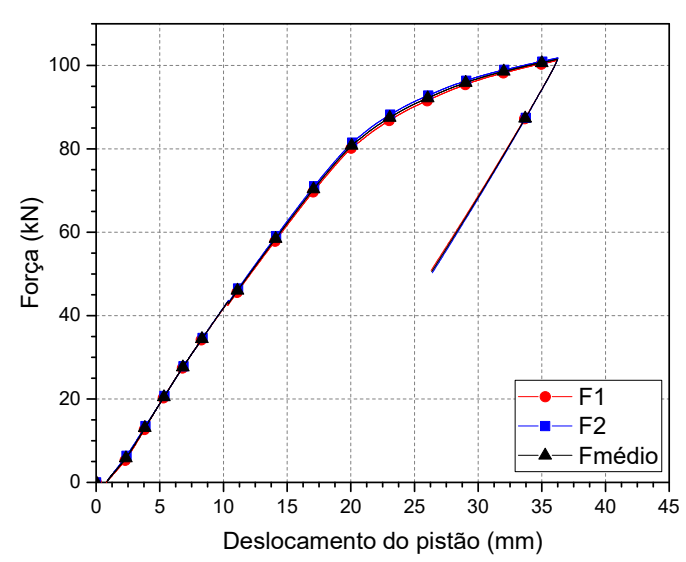

b) Tipologia 4

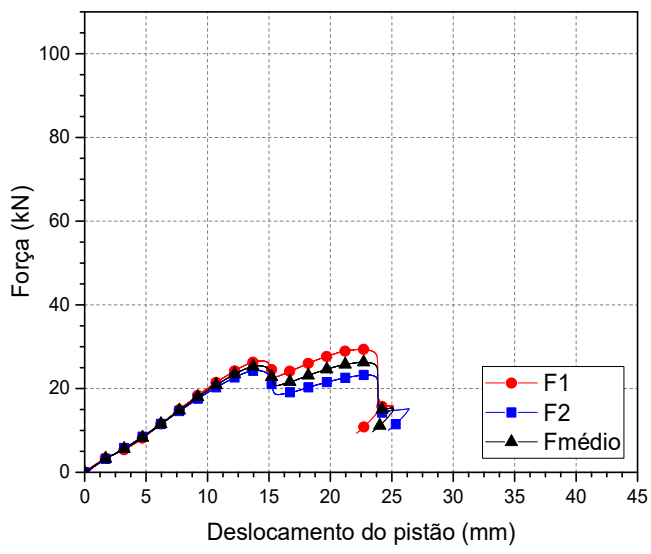

d) Tipologia 6

Fonte: Elaborado pela autora.

Pode-se observar que na tipologia 5, uma das vigas desenvolveu deslocamentos ligeiramente superiores aos da outra provavelmente devido à resistência do concreto em cada lado da ligação (concretado um lado de cada vez), à aderência de cada concreto com as barras passantes e ao aperto das porcas em cada lado (folgas entre os elementos da ligação), ocasionando uma pequena diferença de rigidez de cada lado da ligação.

\section{b) Deslocamentos Verticais}

Os deslocamentos verticais medidos por transdutores de deslocamento em diversos pontos ao longo das vigas são apresentados na Figura 4.29. Os valores de deslocamento vertical são muito coerentes com as posições dos transdutores, podendo ser constatado que o deslocamento próximo da região de ligação é próximo de zero (ponto T4-T5). 
Figura 4.29 - Deslocamento vertical das vigas.

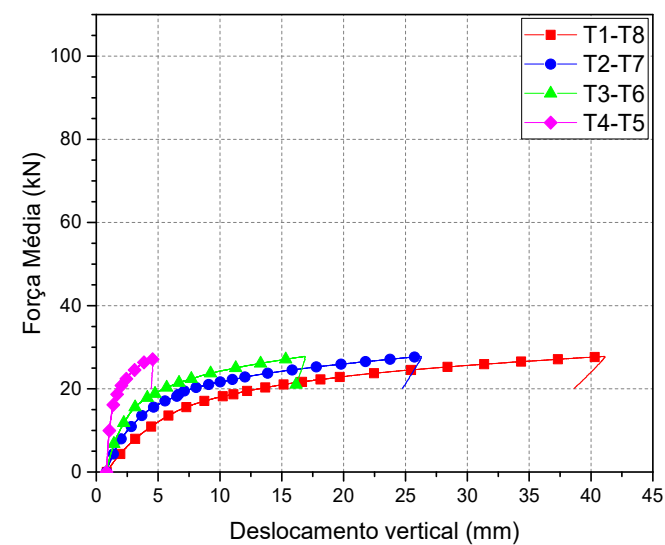

a) Tipologia 3

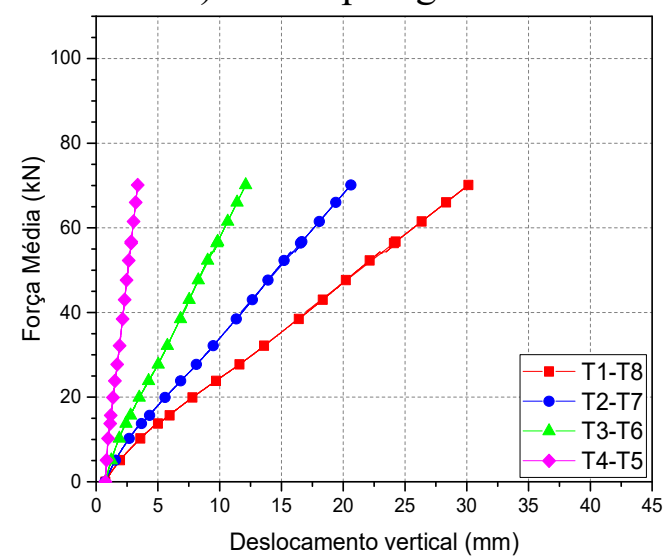

c) Tipologia 5

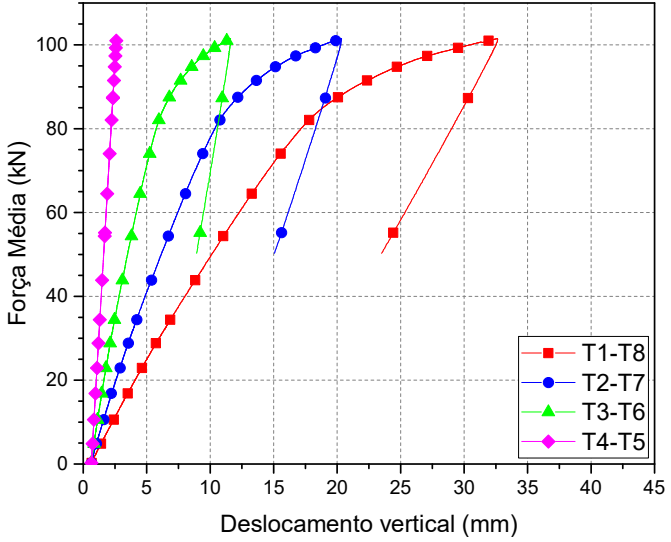

b) Tipologia 4

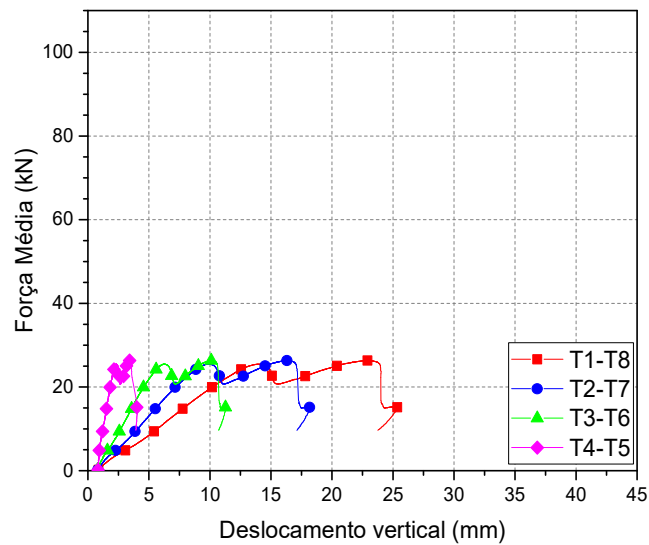

d) Tipologia 6

Fonte: Elaborado pela autora.

Como pode ser visto nas Tipologias 3 e 6, sem o concreto de revestimento na ligação, as extremidades das vigas apresentaram ganhos consideráveis de deslocamento vertical, sem acréscimo na força aplicada, já que o concreto de revestimento trabalha como um enrijecedor do perfil de aço do pilar e das barras passantes. Não interrompendo o concreto de revestimento na ligação, ocorrem acréscimos de deslocamentos devido ao aumento nos valores das forças aplicadas nas extremidades das vigas. A diferença de rigidezes entre os modelos deixa evidente a influência do concreto na região de ligação e do eixo de inércia do pilar misto.

\section{c) Configuração de Ruína}

Na Tipologia 3, o modo de ruptura foi a flexão da mesa do perfil de aço do pilar misto e o descolamento do concreto de revestimento, como é visto na Figura 4.30. Quando o carregamento vertical da viga atingiu $20 \mathrm{kN}$, começaram o descolamento do concreto do 
revestimento e a deformação acentuada da mesa do perfil de aço. Sem a contribuição do concreto de revestimento na ligação, a espessura da mesa era pequena e escoou, sendo o ponto crítico da ligação viga-pilar, o que já era esperado pela previsão teórica no Anexo A.

Figura 4.30 - Configuração final da tipologia 3.

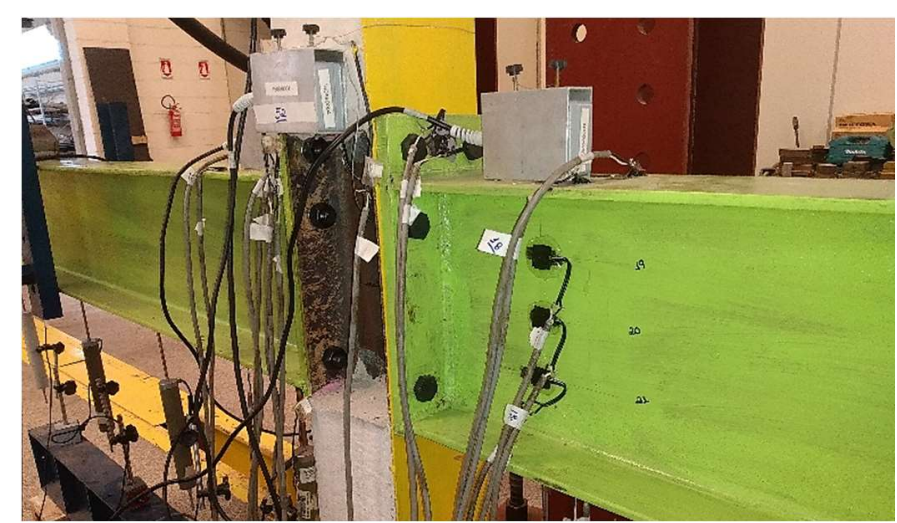

a) Configuração da ligação

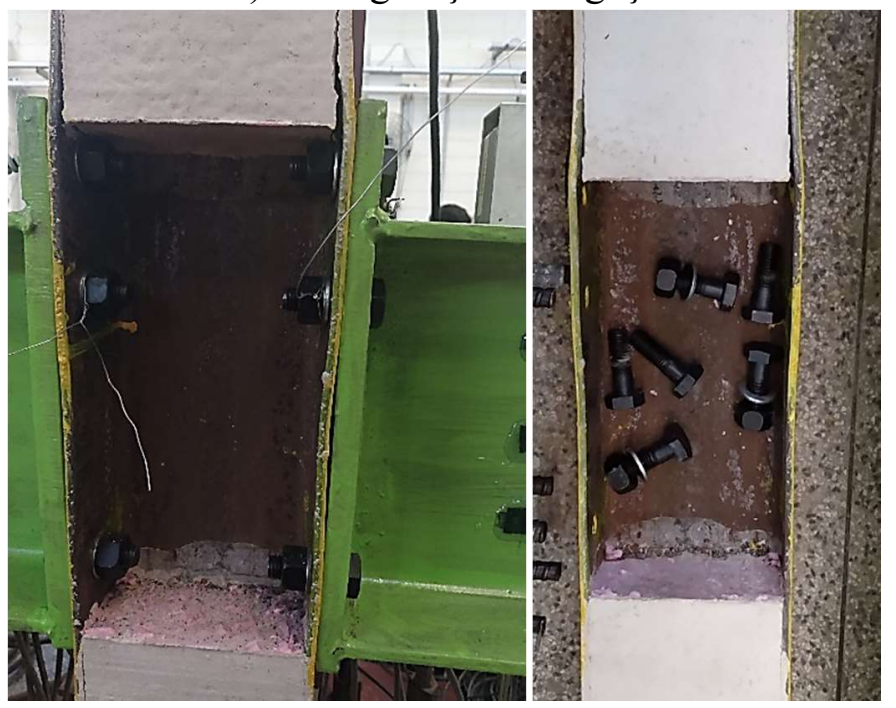

b) Deformada das mesas do pilar misto

Fonte: Elaborado pela autora.

A configuração final da Tipologia 4 é mostrada na Figura 4.31 e o ensaio foi conduzido em duas partes. Na primeira parte, as vigas foram carregadas até $80 \mathrm{kN}$, quando se ouviu um estalo e acreditou-se que a solda havia se rompido. $\mathrm{O}$ ensaio foi interrompido e as vigas descarregadas. Quando foi constatado que a solda continuava intacta, carregou-se novamente as vigas e as curvas plotadas são referentes a essa segunda etapa. Os critérios de parada foram o início do escoamento da viga e das barras passantes, que para um módulo de Young de 200 GPa, a deformação de início de escoamento é de $1850 \mu \varepsilon$ e $4500 \mu \varepsilon$, respectivamente. Além disso, a deformada da chapa de topo e o início da fissuração do concreto de revestimento. 


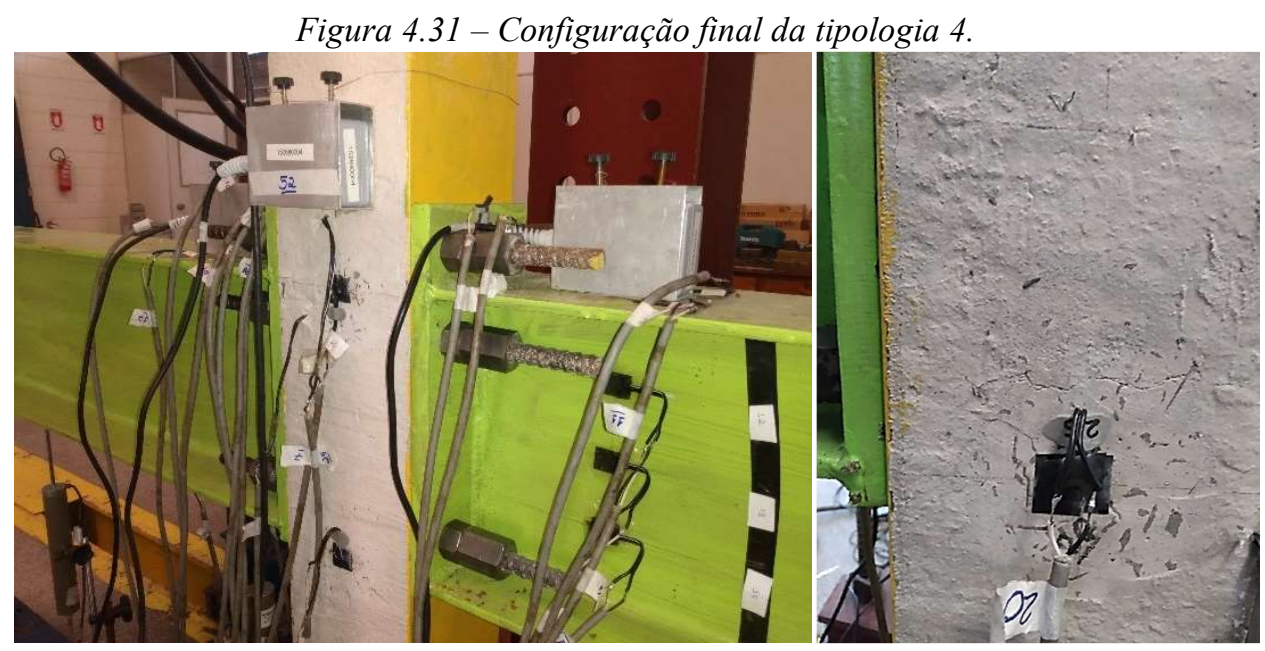

a) Configuração da ligação

b) Fissuras no concreto
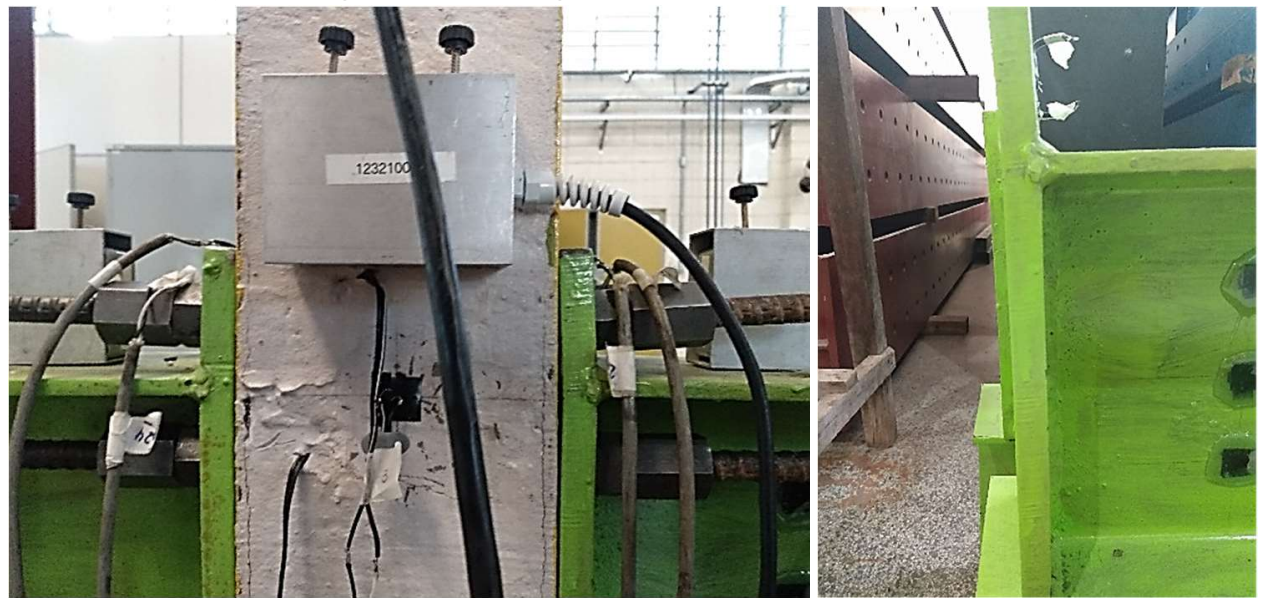

c) Configuração da chapa de topo

Fonte: Elaborado pela autora.

O modo de falha foi o início da ruptura da solda na Tipologia 5 para o carregamento vertical das vigas próximo a $70 \mathrm{kN}$ e decidiu-se interromper o ensaio para que nenhum equipamento fosse danificado (Figura 4.32). Desta forma, os resultados poderão ser analisados parcialmente, pois não foi possível fazer a análise do momento resistente e da capacidade rotacional em estado limite último dos elementos de interesse da ligação. Havia uma diferença de rigidez entre os lados do modelo misto que pode ser observado na Figura 4.32 na qual o concreto de revestimento na ligação possuía bolhas que foram preenchidas com argamassa de alto desempenho, indicando que não houve um perfeito adensamento e acabamento na região e comprometendo a aderência com as barras passantes. Além disso, a passagem da instrumentação das barras passantes permitiu folgas entre a chapa de topo e o pilar misto. 
Figura 4.32 - Configuração final da tipologia 5.

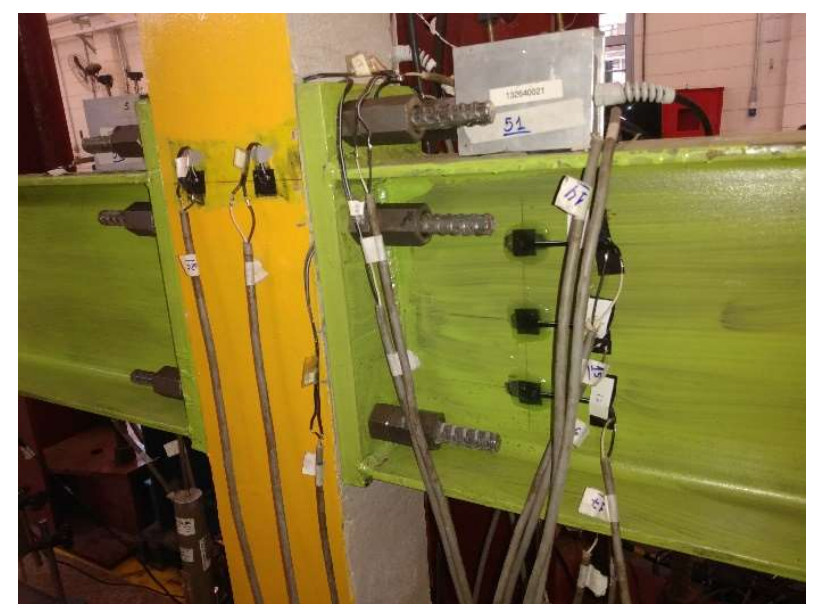

a) Configuração da ligação

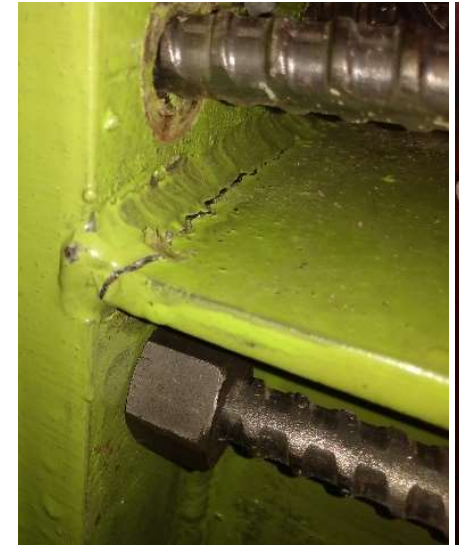

b) Ruptura da solda

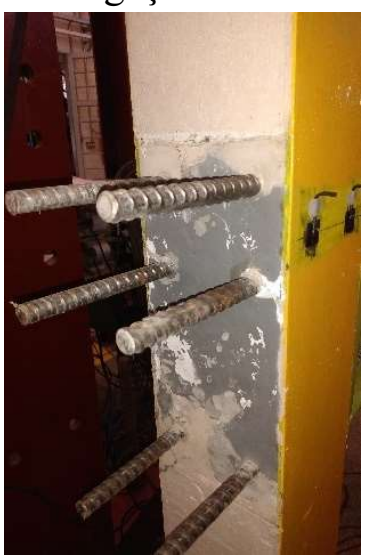

c) Barras Passantes

Fonte: Elaborado pela autora.

A Tipologia 6 não atingiu o colapso e seu comportamento foi caracterizado pela perda de estabilidade devido ao apoio das chapas de topo na pequena espessura das mesas do pilar na região comprimida. As chapas de topo tinham a largura igual ao do pilar que não foi suficiente para transmitir momento fletor da viga para o pilar parcialmente revestido (Figura 4.33). O comportamento do modelo poderia ser alterado por meio de uma chapa de topo com uma largura maior do que do pilar misto e de uma contraplaca soldada entre as mesas do pilar misto na região da ligação. O ensaio foi parado após dois declínios da curva força versus deslocamento e visualmente o início do esmagamento da mesa comprimida do pilar. 
Figura 4.33 - Configuração final da tipologia 6.

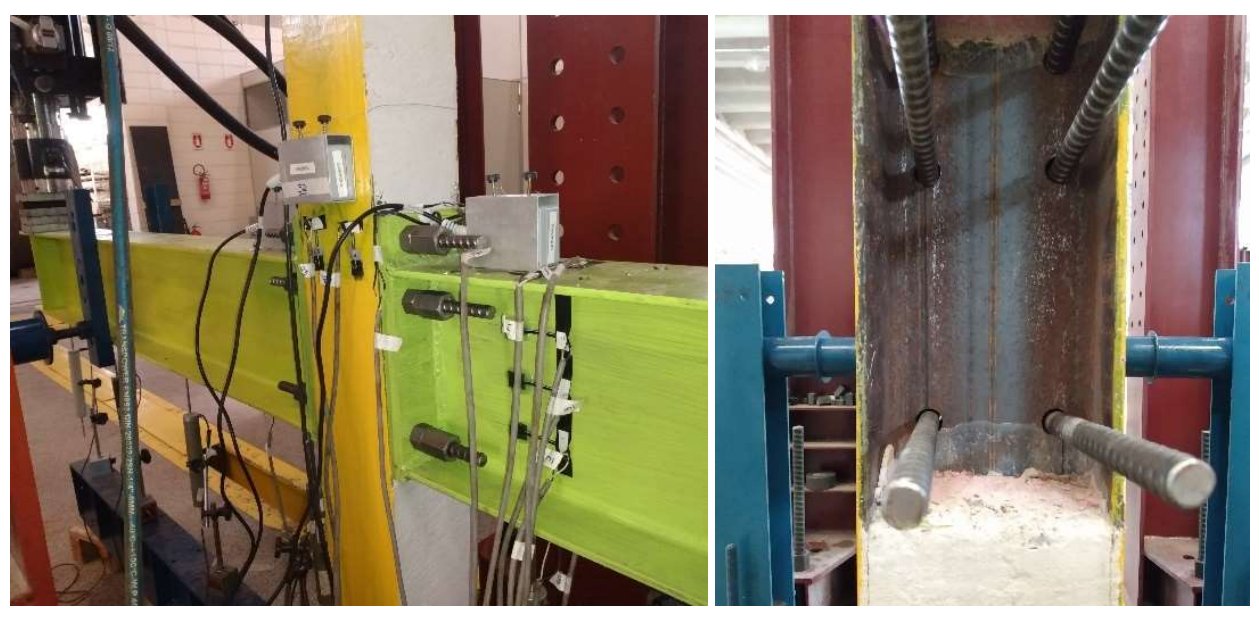

a) Configuração da ligação

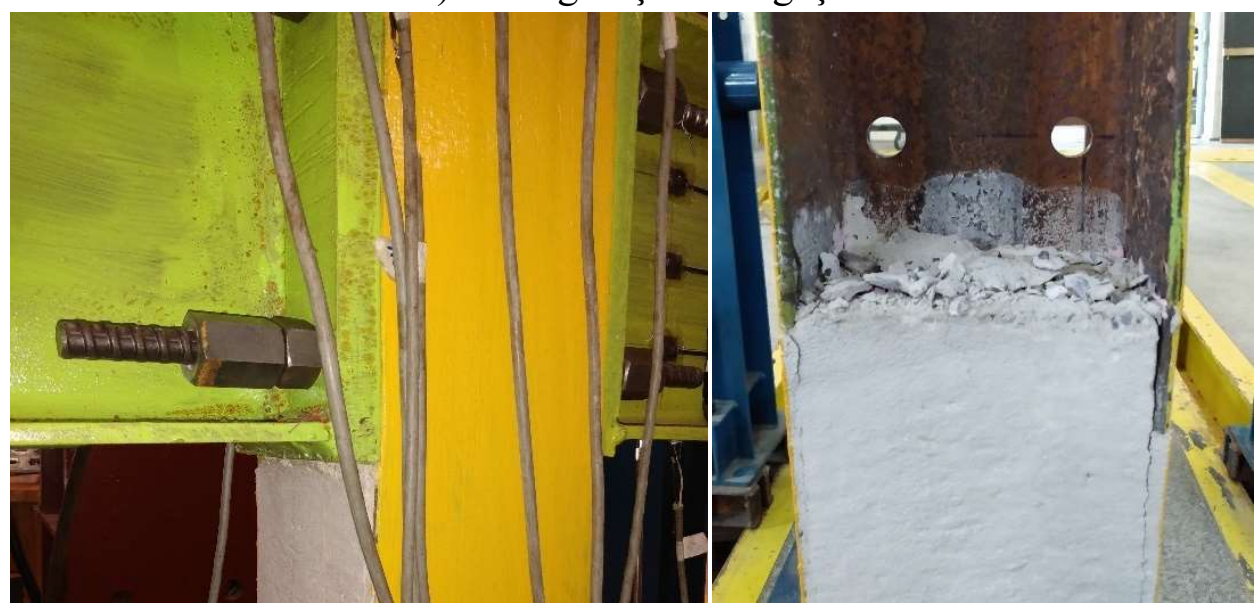

b) Deformada das mesas e descolamento do concreto do pilar misto Fonte: Elaborado pela autora.

\section{d) Deformação Axial das Barras Passantes}

Os extensômetros elétricos colados no centro de cada uma das barras passantes permitiram acompanhar a evolução das deformações axiais nestes elementos. Os resultados de força vertical média x deformação são apresentados na Figura 4.34. As deformações nas barras passantes são mais significativas naquelas posicionadas na região tracionada, e por isso, só essas barras foram instrumentadas. Neste sentido, as deformações nas barras 2 e 3 apresentaram pequenas variações na ordem de grandeza das deformações, sendo utilizada a média desses valores, assim como nos extensômetros posicionados na mesma direção (4-5, 6-7 e 8-9). Esta diferença pode ter sido devido a imperfeições geométricas e aderência ao concreto de 
revestimento. Os parafusos da Tipologia 3 não foram instrumentados, pois os extensômetros seriam danificados com o carregamento das vigas e esses parafusos não se romperam no ensaio.

Figura 4.34 - Deformações nas barras passantes.

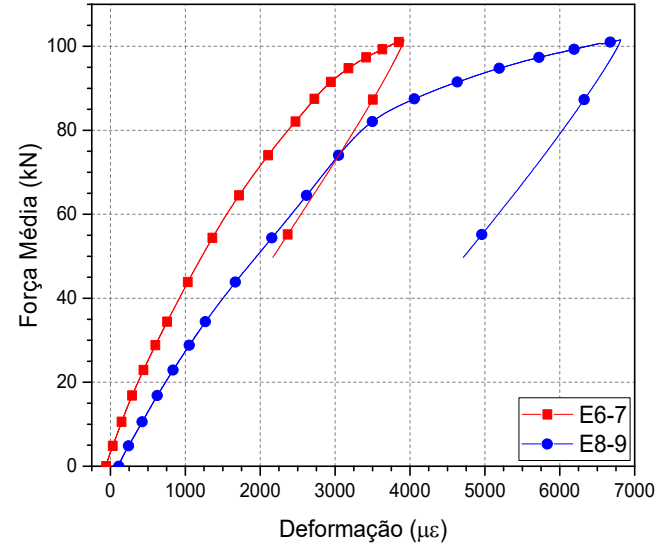

a) Tipologia 4

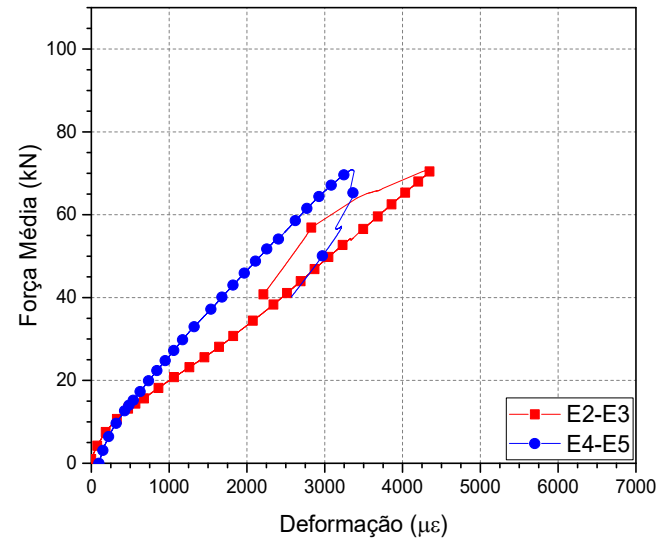

b) Tipologia 5

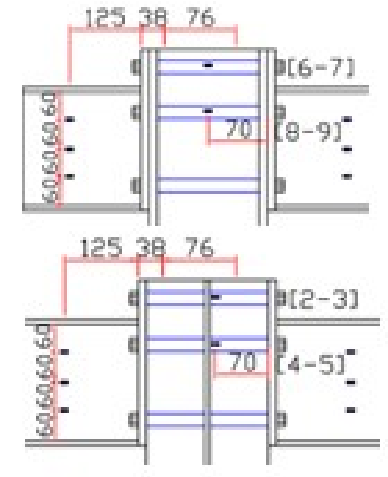

c) Tipologia 6

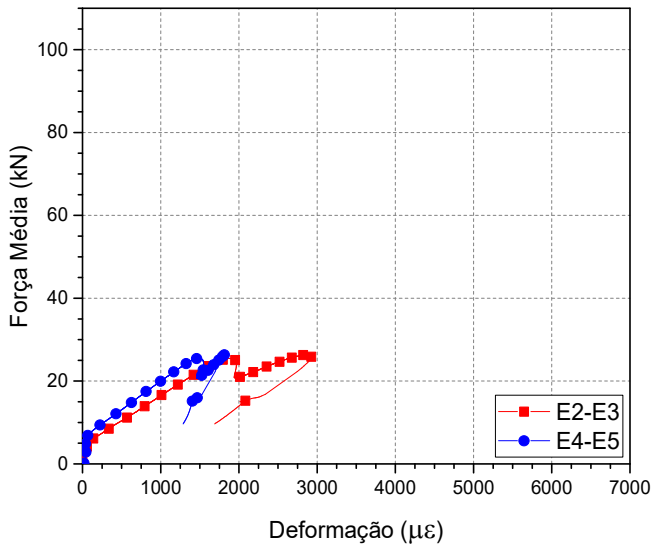

Fonte: Elaborado pela autora.

Nota-se que somente na Tipologia 4 verificou o escoamento das barras passantes na segunda linha de barras (8-9), deformações maiores que $4500 \mu \varepsilon$. A mudança no comportamento das deformações axiais registradas nas barras passantes indica a ocorrência da ruptura em algum/alguns elementos de ligação. Na Tipologia 5, a primeira linha de barras estava próxima ao início do escoamento do aço, porém com a ruptura parcial da solda, os esforços de tração, que eram transmitidos a essa linha de barras, reduziram e houve uma redução das deformações axiais nas barras passantes (2-3). Já na Tipologia 6, as barras passantes estavam no regime elástico e não sofreram grandes deformações, pois o carregamento último das vigas era pequeno. Vale lembrar que foi evitado uma falha de ruptura da barra passante, pois poderia ser perigosa e causar danos aos equipamentos. 


\section{e) Deformação das Chapas de Topo}

A instrumentação de alguns pontos permitiu acompanhar a evolução das deformações em cada uma das chapas de topo isoladamente. Sendo assim, o comportamento das deformações axiais das chapas esquerda e direita do pilar parcialmente revestido apresenta pequena variação um do outro (Figura 4.35). Somente os extensômetros 28 e 29 da Tipologia 4 na mesma posição, mas um em cada chapa de topo, apresentaram diferenças no registro de deformações, no extensômetro 29 ocorreram deformações crescentes e maiores que os registrados na outra chapa. Este comportamento diferenciado é ocasionado pela aderência entre as barras passantes e o núcleo de concreto do pilar parcialmente revestido que, durante o encaixe da porca e contra porca, impede que a força de aperto seja transferida por completo para a outra extremidade da ligação, podendo existir uma folga em um dos lados. Além disso, estas diferenças podem ser atribuídas a possíveis empenamentos da chapa de topo, ocasionados pelo processo de fabricação (soldagem da chapa de topo à viga e perfuração destas para passagem das barras), a eventuais excentricidades na aplicação dos carregamentos nas vigas e a proximidade dos extensômetros às barras passantes.

Nas Tipologias 5 e 6 não foram colados extensômetros na direção vertical devido à falta de recursos humanos e à grande quantidade de ensaios agendados no laboratório. Quando agendaram a realização desses ensaios no laboratório no final de março de 2019, a instrumentação não havia sido terminada, porém decidiu-se dar continuidade para não haver mais atrasos. As tipologias apresentaram tanto os valores de deformação vertical quanto horizontal inferiores àqueles correspondentes ao escoamento do aço e indicaram que a maior espessura das chapas de topo em relação ao modelo piloto trouxe rigidez ao sistema. Entretanto, na Tipologia 4, as deformações da chapa de topo são muito superiores àquelas registradas na Tipologia 3, demonstrando a contribuição do concreto de revestimento na ligação com ganho de capacidade resistente. O mesmo pode ser verificado entre as Tipologias 5 e 6 . 
Figura 4.35 - Deformações nas chapas de topo.

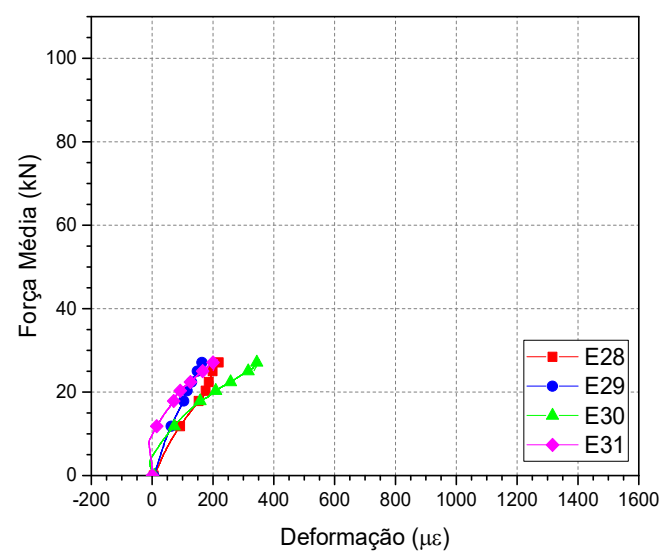

a) Tipologia 3

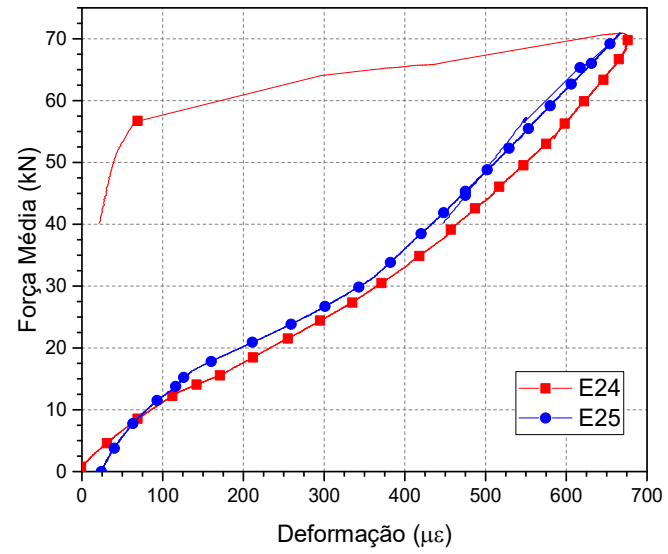

c) Tipologia 5

Fonte: Elaborado pela autora.

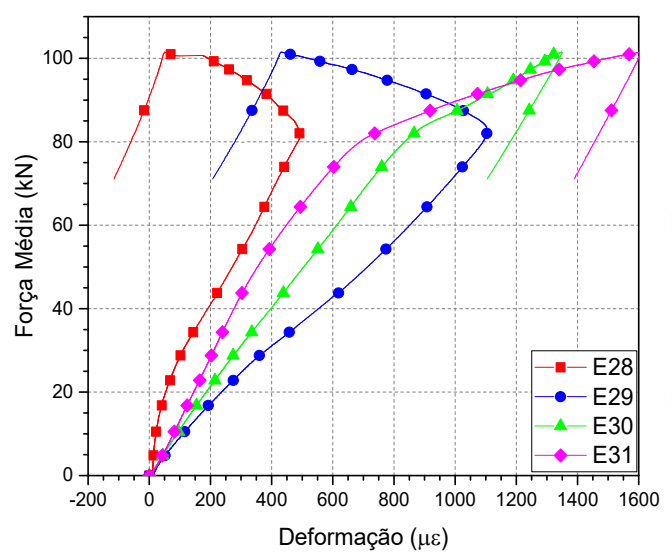

b) Tipologia 4

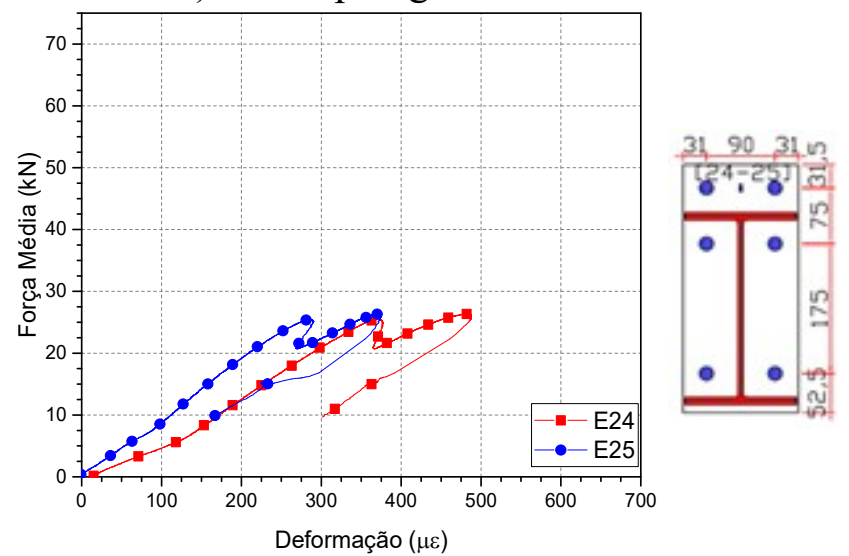

d) Tipologia 6

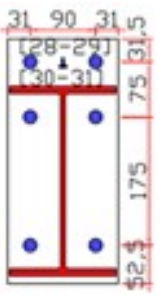

\section{f) Deformação Axial das Vigas}

Na Figura 4.36 são apresentados os principais resultados de deformação registrados nas mesas e almas das vigas direita e esquerda das tipologias. Os valores de deformação das Tipologias 3 e 6, sem concreto na ligação, foram pequenos e não ultrapassaram 1 \%o, não chegaram a atingir os valores correspondentes ao escoamento do aço em nenhum dos componentes das vigas de aço. Ao analisar a ocorrência de escoamento nas mesas das vigas, considerando os valores de resistência ao escoamento obtidos nos ensaios de caracterização (na ordem de $1850 \mu \varepsilon$ ), verifica-se que ocorreu somente na mesa tracionada da Tipologia 4 .

Comparando as deformações nas almas para as Tipologias 3 a 6 se verifica que nas Tipologias 3 e 4, com a ligação no eixo de maior inércia, a linha neutra encontra-se na posição esperada próxima a H/2. Por outro lado, nas Tipologias 5 e 6 , encontra-se acima de H/2 para todos os estágios de carregamento. A distribuição de deformações nas almas das vigas das Tipologias 5 e 6 levou a concluir que a linha neutra havia se deslocado em relação a H/2 devido 
à diferença de rigidez entre as regiões tracionada e comprimida ocasionada pela maior rigidez da chapa de topo e pela transferência das forças de compressão diretamente ao núcleo de concreto. Nas Tipologias 3 e 4, a linha neutra encontra-se próxima a H/2; isto significa que a aderência entre as barras passantes e o concreto de revestimento e o núcleo de concreto comprimido, contribuiu para "equilibrar" a rigidez entre as porções tracionada e comprimida.

Em relação às deformações médias das mesas das vigas direita e esquerda, verifica-se que nas mesas tracionadas o comportamento das deformações entre pontos simétricos é idêntico. Nas mesas comprimidas também se observa simetria de comportamento das deformações. Se fossem comparadas as deformações na viga encontradas à direita e à esquerda do pilar misto, foram constatadas pequenas diferenças que não interferiam na consideração da média. Essa diferença pode ser ocasionada pelo empenamento da viga esquerda, por rotação desta, por alguma excentricidade na introdução da força vertical nela aplicada ou pela diferença de rigidez entre os lados da ligação.

Figura 4.36-Deformações nas vigas.

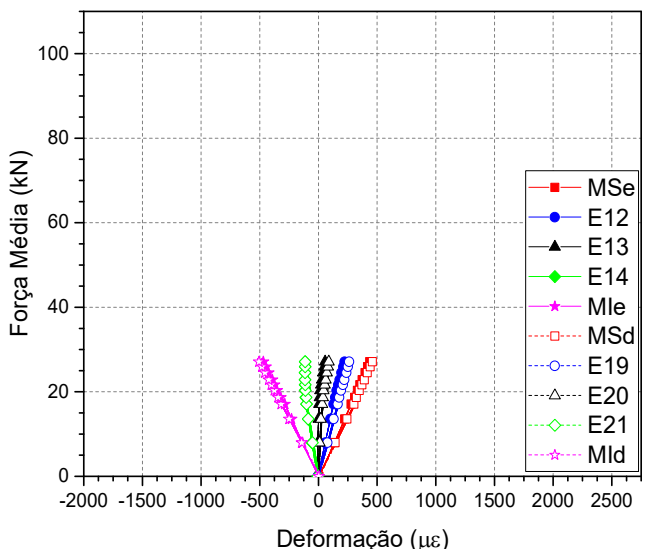

a) Tipologia 3

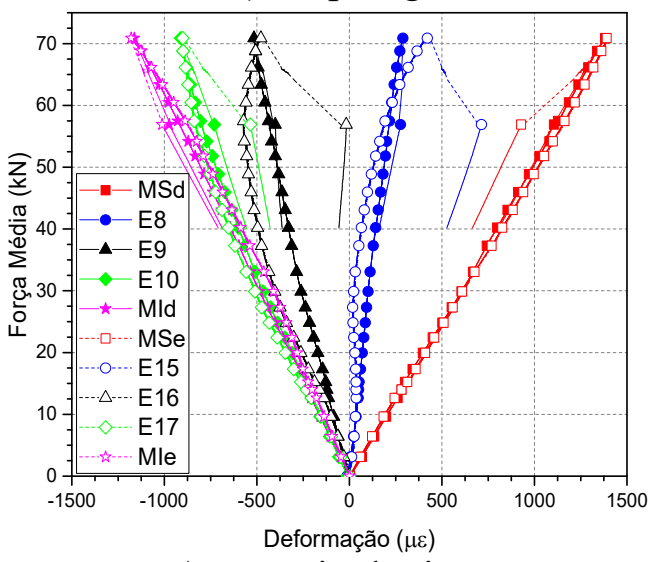

c) Tipologia 5

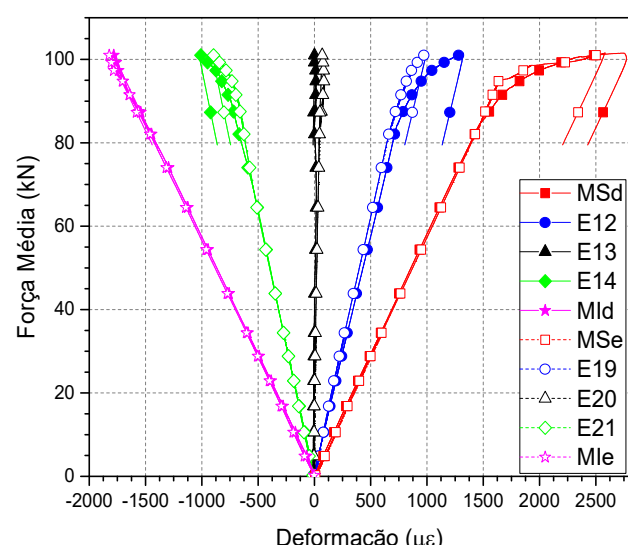

b) Tipologia 4

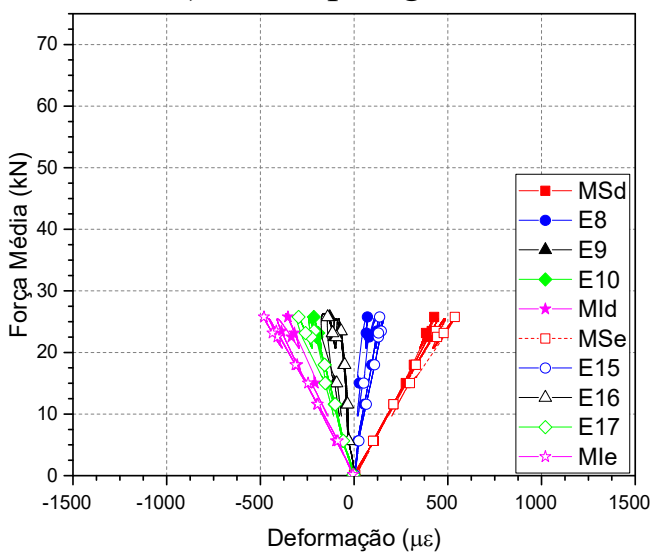

d) Tipologia 6
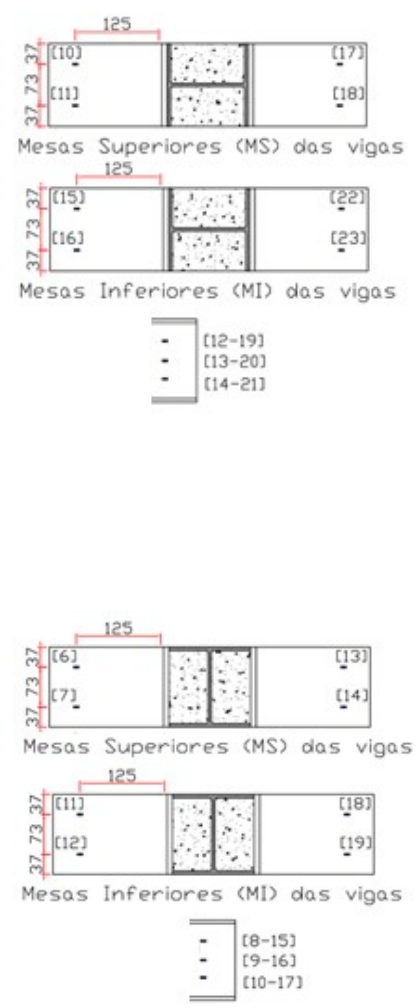

Fonte: Elaborado pela autora. 


\section{g) Pilar Misto}

O pilar misto está submetido a tensões verticais provenientes da compressão do pilar e horizontais decorrentes da solicitação nas vigas, e a deformações transversais do concreto de revestimento. Apesar da tentativa de acompanhar as deformações no pilar misto na região da ligação, alguns resultados encontrados apresentaram pequenas deformações que não geraram maiores discussões. Os pontos de instrumentação dispostos nos perfis de aço dos pilares mistos presentes nas Tipologias 3 e 4 permitem conhecer a influência do concreto na região da ligação. Tais valores de deformação são apresentados nos gráficos das Figuras 4.37 e 4.38, em função da força média aplicada nas extremidades das vigas. Já nas Tipologias 5 e 6 a instrumentação não foi concluída devido à falta de recursos humanos e à grande quantidade de ensaios agendados no laboratório, e não foi possível analisar as deformações na região comprimida do pilar misto.

Figura 4.37 - Deformações nos perfis de aço dos pilares mistos.

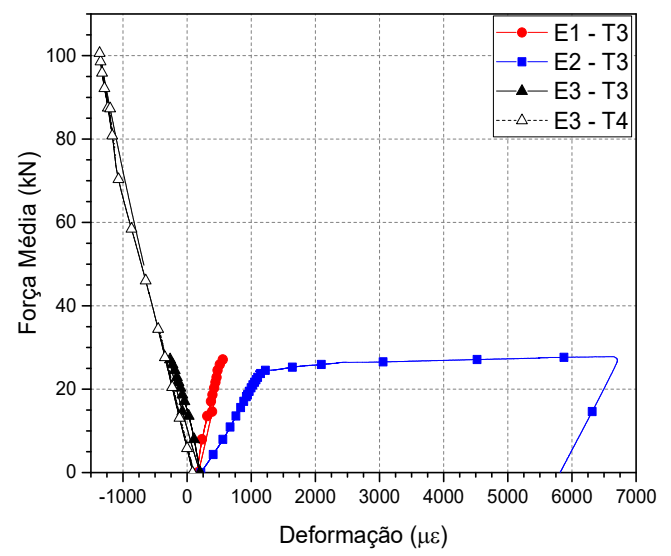

Deformações na alma das Tipologias 3 e 4
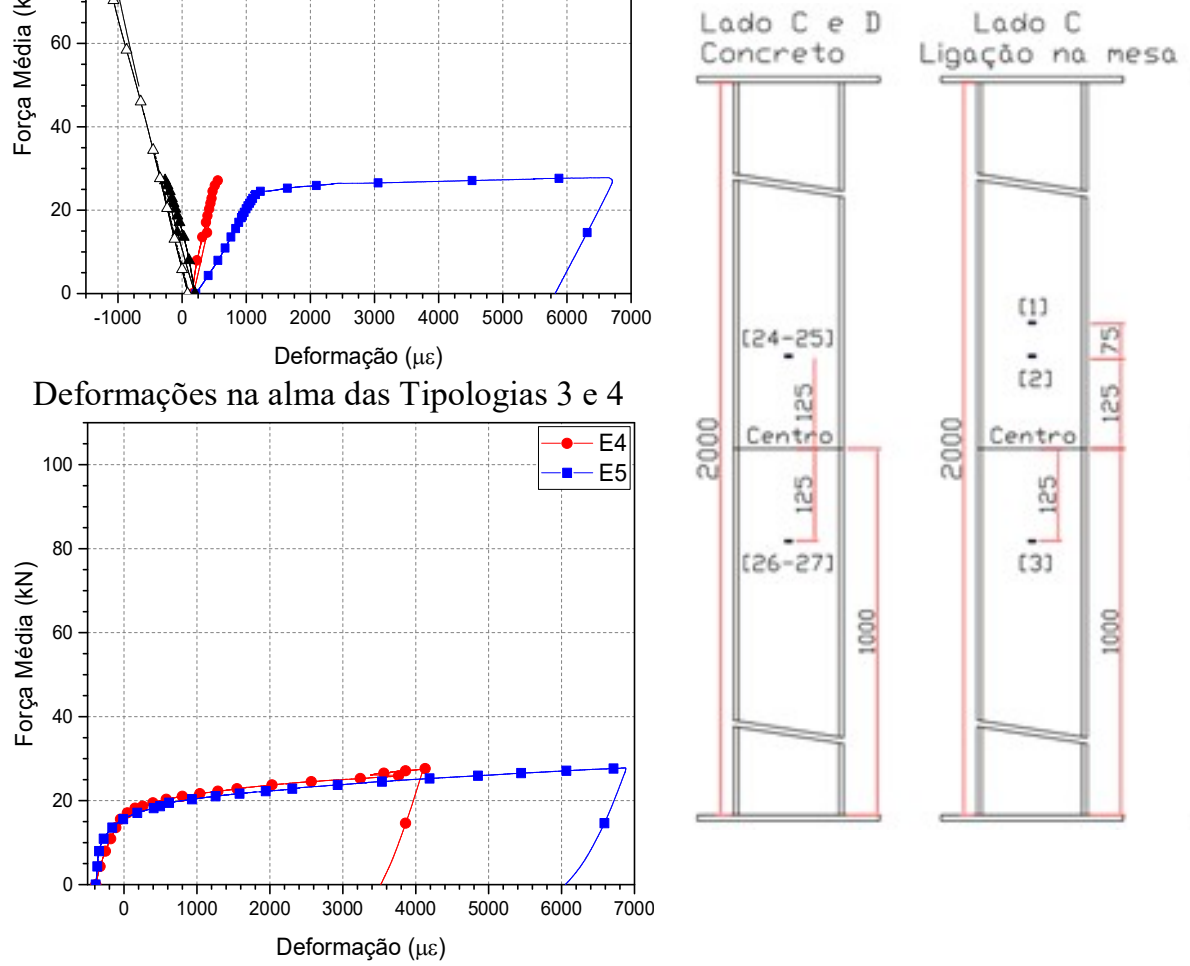

Lado $A$ e $B$

Deformações nas mesas da Tipologia 3 Fonte: Elaborado pela autora. 
Figura 4.38 - Deformações no concreto comprimido da Tipologia 4.

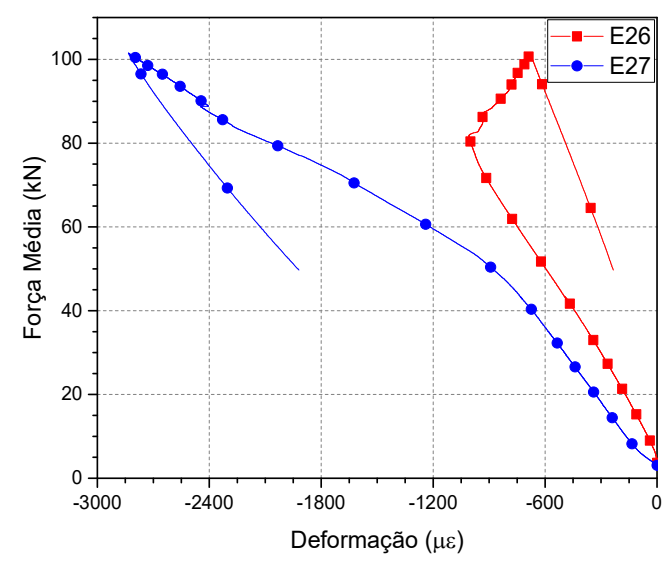

Fonte: Elaborado pela autora.

Os extensômetros 2, 4 e 5 da Tipologia 3 mostram que o perfil de aço do pilar misto escoou na região tracionada e foi o modo de falha da ligação. Por outro lado, na Tipologia 4 na região tracionada, os extensômetros apresentam deformações próximas a zero que não foram plotadas, mas na região comprimida, os extensômetros 3, 26 e 27 demonstram que tanto o concreto de revestimento quanto a alma do perfil de aço estavam próximos do esmagamento e plastificação, respectivamente. Novamente observou-se a influência do concreto de revestimento na região da ligação, comportando-se com um enrijecedor para o perfil de aço do pilar misto. As deformações no concreto de revestimento nos lados direito e esquerdo do pilar misto apresentaram variações no estágio final do ensaio que podem ser ocasionadas por rotação e excentricidade do carregamento aplicado no pilar misto, e a diferença entre as rigidezes do concreto de cada lado do pilar.

\section{h) Rotação da Ligação}

Nos modelos cruciformes é necessário considerar a rotação do pilar uma vez que este não teve o deslocamento impedido na sua extremidade para analisar a rotação da ligação. Logo, para avaliar a rotação relativa da ligação foram utilizados inclinômetros nas vigas direita e esquerda e no pilar (Figura 4.39). Como era esperado, as Tipologias 3 e 6 apresentam baixa capacidade de transmitir momento fletor e rotações mais expressivas, pois há interrupção do concreto de revestimento na ligação e o perfil de aço do pilar é esbelto e deforma-se. Já as Tipologias 4 e 5 comportam-se como uma ligação com maior rigidez, pois o concreto de 
revestimento com fibras do pilar misto trabalha como um enrijecedor. Vale lembrar que a armadura foi interrompida na ligação para facilitar o processo construtivo.

Figura 4.39 - Rotação média das ligações.

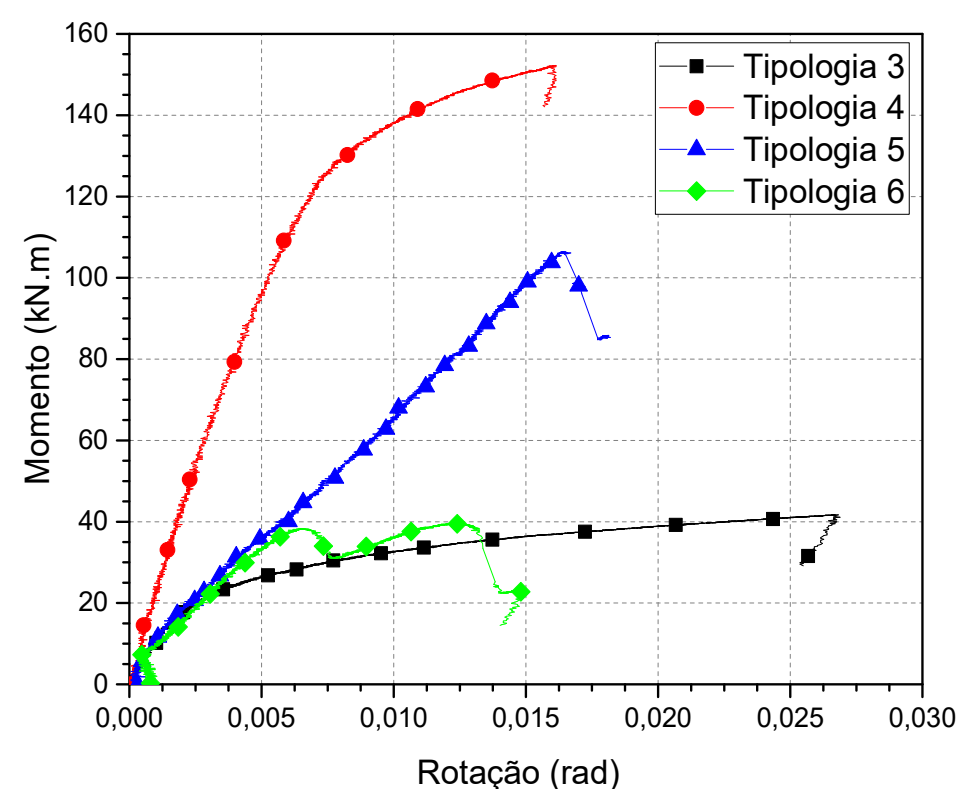

Fonte: Elaborado pela autora.

Pela comparação das duas curvas das Tipologias 5 e 6 , nas quais a ligação é no eixo de menor inércia do pilar misto, é possível notar que os dois modelos apresentaram rigidez inicial da mesma ordem de grandeza e comportamento semelhante até atingirem o momento de 40 kN.m. Porém, os ganhos em capacidade resistente com a presença do concreto na ligação podem ser observados, já que o momento resistente da Tipologia 6 foi de 39,51 kN.m, enquanto que o da Tipologia 5 foi de 106,37 kN.m. Isto representa um acréscimo na capacidade resistente na ordem de $169 \%$.

O mesmo é observado entre as Tipologias 3 e 4, nas quais a ligação é no eixo de maior inércia do pilar misto, porém, as rigidezes iniciais não são da mesma ordem de grandeza. $\mathrm{O}$ momento resistente da Tipologia 3 foi de 41,69 kN.m, enquanto que o da Tipologia 4 foi de 152,27 kN.m, mostrando um aumento no momento resistente na ordem de $265 \%$ e na rigidez inicial na ordem de $306 \%$ com a presença do concreto na ligação. Além disso, o comportamento entre as rotações ocorridas nas vigas à direita e à esquerda do pilar misto é ligeiramente diferente devido à excentricidade na aplicação do carregamentos e folgas nos elementos da ligação em um dos lados, mas não interferiam na consideração da média da rotação.

A rigidez inicial da ligação obtida experimentalmente tem como referência um ponto da curva referente a dois terços do valor do momento último experimental, para os valores obtidos pela leitura dos inclinômetros. Para classificar as ligações quanto à sua rigidez, os valores foram 
comparados com os limites apresentados do Eurocode 3 (2005) e ABNT NBR 8800 (2008). Os valores limites foram calculados adotando um vão de 3,00 m, que é um vão coerente com as dimensões da seção transversal e do comprimento das vigas. O resumo dos cálculos está apresentado na Tabela 4.7.

Tabela 4.7 - Cálculo da rigidez inicial e os limites de rigidez.

\begin{tabular}{|c|c|c|c|c|}
\hline Modelo & Tipologia 3 & Tipologia 4 & Tipologia 5 & Tipologia 6 \\
\hline $2 / 3 M_{u}(k N . m)$ & 27,79 & 101,51 & 70,91 & 26,34 \\
\hline$\phi\left(\operatorname{rad} .10^{-3}\right)$ & 6,03 & 5,42 & 10,60 & 3,73 \\
\hline$S_{i}(\mathbf{k N} . \mathbf{m} / \mathbf{r a d})$ & 4609 & 18729 & 6690 & 7062 \\
\hline \multirow{3}{*}{ Viga } & \multicolumn{2}{|c|}{ Momento de Inércia $\left(\mathrm{cm}^{4}\right)$} & \multicolumn{2}{|c|}{4937} \\
\hline & \multicolumn{2}{|c|}{ Comprimento $(\mathrm{cm})$} & \multicolumn{2}{|c|}{300} \\
\hline & \multicolumn{2}{|c|}{$\mathrm{I}_{\mathrm{v}} / \mathrm{L}_{\mathrm{v}}\left(\mathrm{cm}^{3}\right)$} & \multicolumn{2}{|c|}{16,46} \\
\hline \multirow{2}{*}{ Classificação } & \multicolumn{2}{|c|}{$k_{b} E \frac{I_{v}}{L_{v}}(k N . m / r a d)$} & \multicolumn{2}{|c|}{26994} \\
\hline & \multicolumn{2}{|c|}{$0,5 E \frac{I_{v}}{L_{v}}(k N \cdot m / r a d)$} & \multicolumn{2}{|c|}{1687} \\
\hline
\end{tabular}

Fonte: Elaborado pela autora.

Estes valores foram plotados na Figura 4.40a, onde são novamente apresentadas as curvas momento x rotação das ligações para análise do comportamento das tipologias quanto à rigidez. Pode-se observar que todas as tipologias têm comportamento típico semirrígido. É importante ressaltar que os valores limites foram calculados para um vão de 3,00 m e para vãos menores, estes resultam em valores limites maiores.

Figura 4.40 - Classificação das ligações.

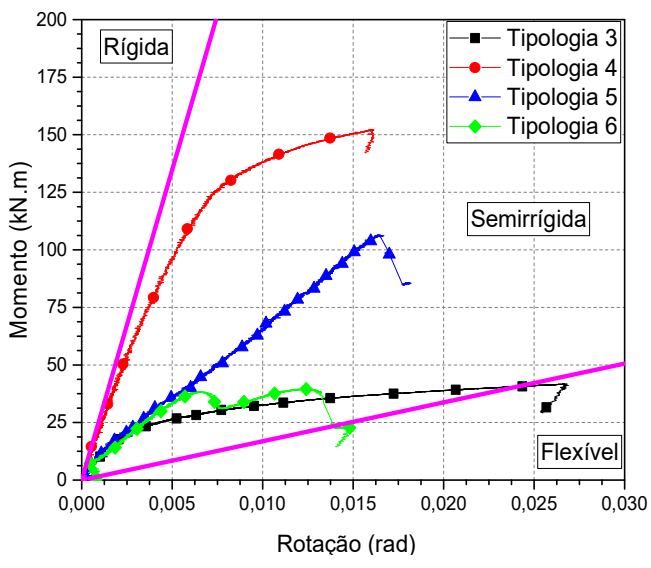

a) Classificação quanto a rigidez.

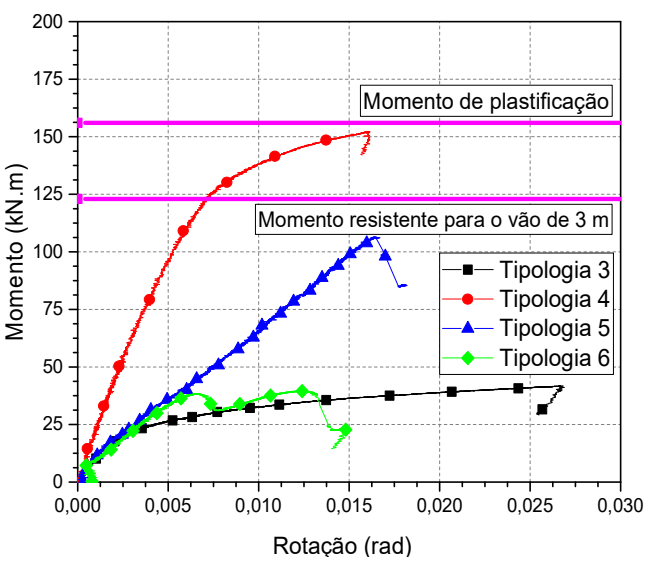

b) Classificação quanto a resistência.

Fonte: Elaborado pela autora. 
As curvas momento x rotação das ligações também são apresentadas com os limites para classificação da ligação quanto à resistência na Figura 4.40b. Uma ligação é considerada de resistência total se possui momento resistente maior que o momento resistente da viga. Os cálculos dos valores limites foram feitos segundo a ABNT NBR 8800 (2008). Além disso, estes foram feitos com a resistência ao escoamento da viga obtida experimentalmente em ensaios de caracterização e não é feita a consideração de nenhum coeficiente de segurança. A capacidade resistente da viga de aço isolada foi calculada para um vão de 3,00 m para verificação da flambagem lateral com torção (FLT). O momento de plastificação da viga de aço é de 156 kN.m para $\mathrm{f}_{\mathrm{y}}=36,5 \mathrm{kN} / \mathrm{cm}^{2}$. Entretanto, para o vão de 3,00 m, o momento resistente da viga é de 123 kN.m (para o índice de esbeltez entre $\lambda \mathrm{p}<\lambda<\lambda \mathrm{r}$ ). A Tipologia 4, com concreto na ligação no eixo de maior inércia do pilar misto, apresenta momento resistente maior que o da viga isolada, sendo de resistência total, em contrapartida, as outras tipologias estudadas de resistência parcial. Vãos maiores resultariam em capacidades resistentes menores ainda, porém vão menores resultariam em momentos resistentes próximos do momento de plastificação, tornando todas as ligações de resistência parcial.

\subsubsection{Breve Discussão do Eixo de Inércia do Pilar Misto}

Nos resultados, até aqui apresentados, fica evidente a contribuição do concreto de revestimento na ligação no ganho de capacidade resistente, comparando os resultados das Tipologias 4 e 5 com os resultados das Tipologias 3 e 6 sem concreto na ligação. Isso é possível, pois o concreto com fibras comporta-se como um suporte na região tracionada para as barras passantes e um enrijecedor na região comprimida para o perfil de aço do pilar misto. Porém, a variação do eixo de inércia do pilar misto ainda não foi explorada. Os resultados das Tipologias 4 e 5 são confrontados na Figura 4.41 por apresentarem o mesmo tipo de ligação, só variando o eixo de inércia do pilar misto e a espessura da chapa de topo.

Verifica-se que a variação do eixo de inércia do pilar misto influencia a rigidez inicial da ligação. Há uma diferença na ordem de 180\% entre as rigidezes da Tipologia 4 (maior inércia) e Tipologia 5 (menor inércia). Portanto, a ligação no eixo de menor inércia do pilar tem menor rigidez, porém, a ligação proposta mostrou-se eficiente para os dois eixos de inércia do pilar misto. Além disso, há um acréscimo de 43\% na capacidade resistente da ligação no eixo de maior inércia do pilar misto, entretanto, a ruptura parcial da solda na Tipologia 5, impediu que a ligação atingisse a plastificação como a Tipologia 4 . 
Figura 4.41 - Variação do eixo de inércia do pilar misto.

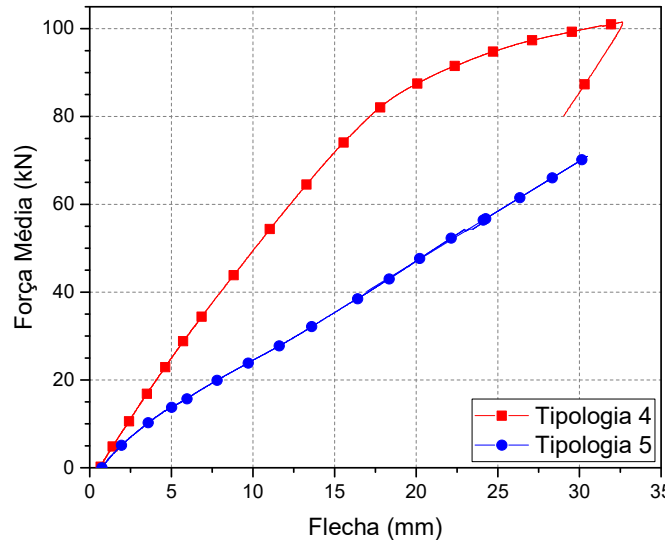

a) Flecha das vigas $(\mathrm{mm})$

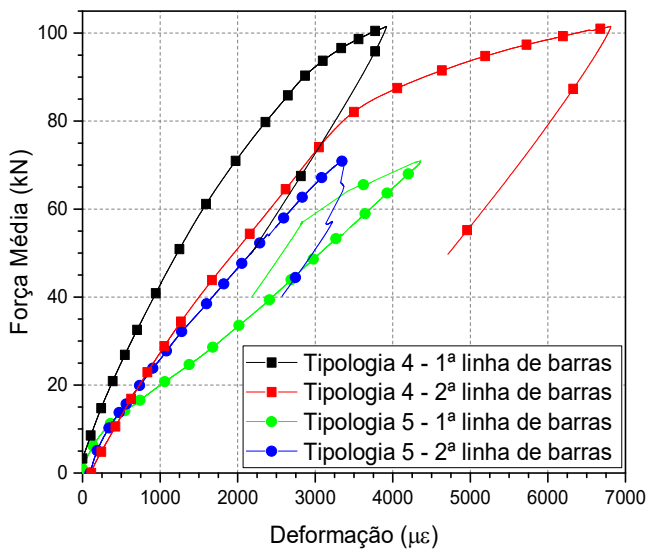

c) Deformações nas barras passantes

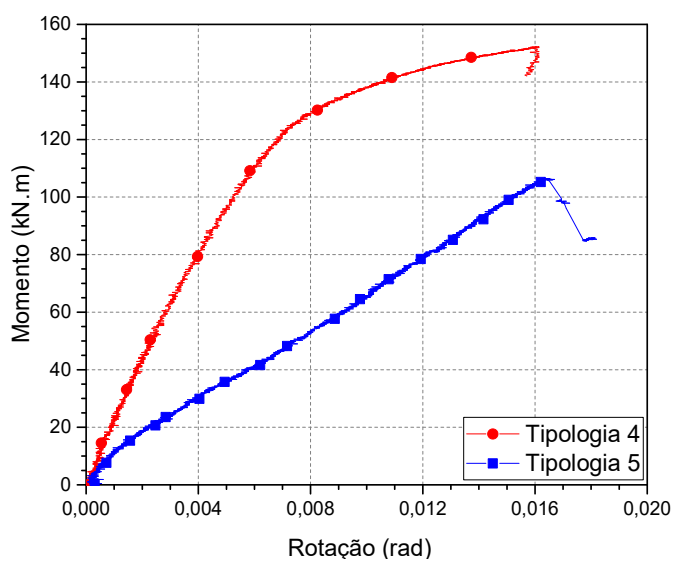

b) Rotação da ligação

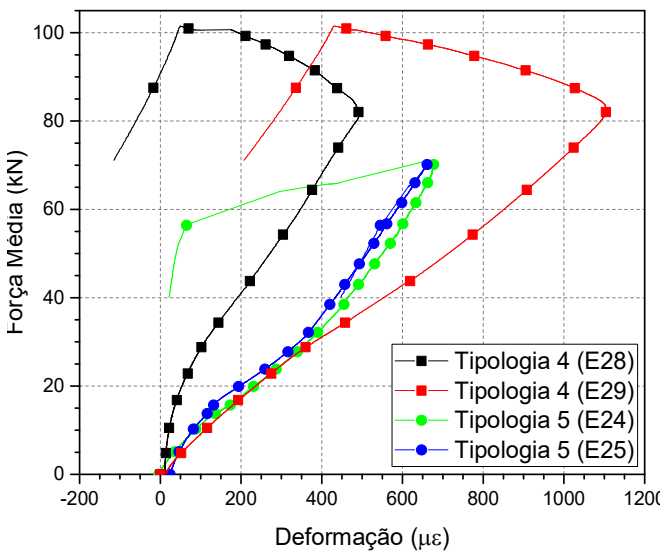

d) Deformações nas chapas de topo

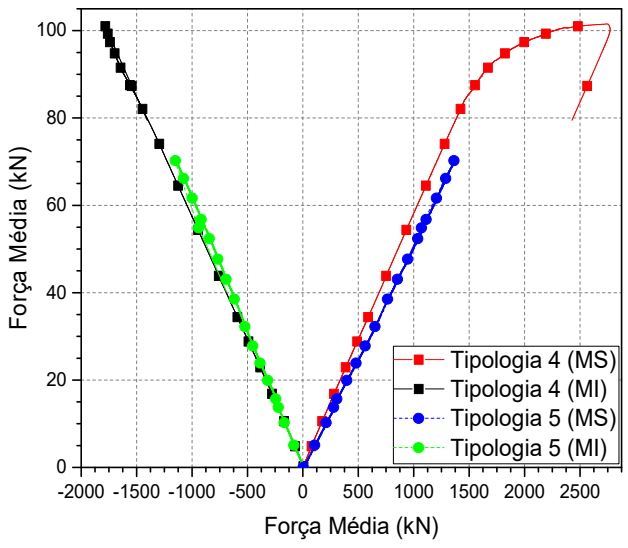

e) Deformações nas mesas superior (MS) e inferior (MI) das vigas

As deformações nas mesas superiores e inferiores das vigas exibem um comportamento semelhante para um mesmo nível de carregamento, apesar da linha neutra ter variado para cada ligação devido à diferença entre as rigidezes da região tracionada e da região comprimida. Por fim, constata-se que a segunda linha das barras passantes, abaixo da mesa superior da viga, apresentou um comportamento similar, porém, a primeira linha apresentou divergências. Isso é 
em razão da ligeira a mudança na linha de plastificação, na medida em que a espessura da chapa de topo aumenta na Tipologia 5, deixando a chapa de topo mais rígida e solicitando mais as barras passantes, para um mesmo nível de carregamento. A divergência entre as deformações da chapa de topo da Tipologia 4 é ocasionado pela aderência entre as barras passantes e o núcleo de concreto do pilar parcialmente revestido que, durante o encaixe da porca e contra porca, impede que a força de aperto seja transferida por completo para a outra extremidade da ligação, podendo existir uma folga em um dos lados. Somando-se a isso, estas diferenças podem ser atribuídas a possíveis empenamentos da chapa de topo, a eventuais excentricidades na aplicação dos carregamentos nas vigas e a proximidade dos extensômetros às barras passantes. 


\section{SIMULAÇÃO NUMÉRICA}

Este capítulo é dedicado à apresentação da metodologia adotada no desenvolvimento e aplicação dos modelos numéricos para o estudo do comportamento das ligações com chapa de topo estendida, barras passantes e concreto de revestimento. A modelagem computacional da ligação viga-pilar foi realizada em duas fases. Após a realização da investigação experimental e com base nos resultados, na primeira fase foram realizadas a calibração e a validação do modelo numérico. Em seguida, foi desenvolvida uma análise paramétrica utilizando o modelo numérico validado. Assim, são apresentadas as hipóteses assumidas para a elaboração dos modelos numéricos como a definição da geometria, os tipos de elementos finitos utilizados e a representação das relações constitutivas dos materiais. Estas simulações também possibilitaram a análise de parâmetros que não foram avaliados experimentalmente, como a resistência do aço, a geometria da ligação e o carregamento do pilar.

O software FX+DIANA ${ }^{\circledR}$ v. 9.6 foi escolhido para a modelagem computacional das ligações viga-pilar desenvolvidas neste trabalho devido às propriedades mecânicas dos materiais disponíveis no programa que possibilitam a melhor representação do modelo físico. Além disso, por ser um programa em elementos finitos baseado no método dos deslocamentos, permite a realização de análises não lineares. O método fornece valores aproximados que podem ser melhorados a partir do refinamento da malha ou da função de aproximação de deslocamentos nos nós. Todos os modelos numéricos foram processados pelo software DIANA versão 9.6, porém foi utilizado um software específico para o pré e pós processamento, denominado de Midas $\mathrm{Fx}+$, que tornou possível ganhos significativos de produtividade na fase de construção da malha de elementos finitos.

Neste capítulo é apresentado a análise paramétrica das Tipologias 4 e 5, ligações nos eixos de maior e menor inércia do pilar misto sem interrupção do concreto de revestimento, respectivamente. Optou-se pela não simulação numérica da Tipologia 3 por ser uma ligação típica e da Tipologia 6, que apesar de ser uma ligação no eixo de menor inércia do pilar misto e há falta de estudos sobre esse tema, apresentou instabilidades no ensaio do modelo físico, requerendo um estudo para contornar os problemas apresentados. As variáveis analisadas foram determinadas segundo pesquisas realizadas sobre parâmetros que influenciam o comportamento da ligação. A seguir, são descritos os principais aspectos referentes aos modelos numéricos das tipologias analisadas e os principais resultados das simulações numéricas desenvolvidas. 


\subsection{Elemento Finito e Geometria}

Para a ligação viga-pilar com chapa de topo estendida e barras passantes foi desenvolvido um modelo tridimensional em elementos finitos cujas características são apresentadas na Figura 5.1. Para a simulação numérica do concreto e do aço foi utilizado o elemento TE12L. Trata-se de um elemento sólido tetraédrico e isoparamétrico com 4 nós que se baseia na interpolação linear para deslocamentos e de integração de Gauss. Cada nó apresenta três graus de liberdade, sendo estes os deslocamentos de translação nas direções x, y e z. Por tratar-se de um elemento com aproximação linear para os deslocamentos, é necessária uma maior discretização da malha de elementos finitos e a malha utilizada é composta por volta de 200.000 elementos finitos sólidos e de interface. Os elementos sólidos possuem, na sua maioria, dimensões na ordem de $15 \mathrm{~mm}$, somente na região da ligação há um maior refinamento da malha, com dimensões na ordem de $10 \mathrm{~mm}$, devido ao estudo previamente realizado sobre a influência da discretização da malha na ligação.

Figura 5.1 - Modelo numérico tridimensional e elementos finitos utilizados.

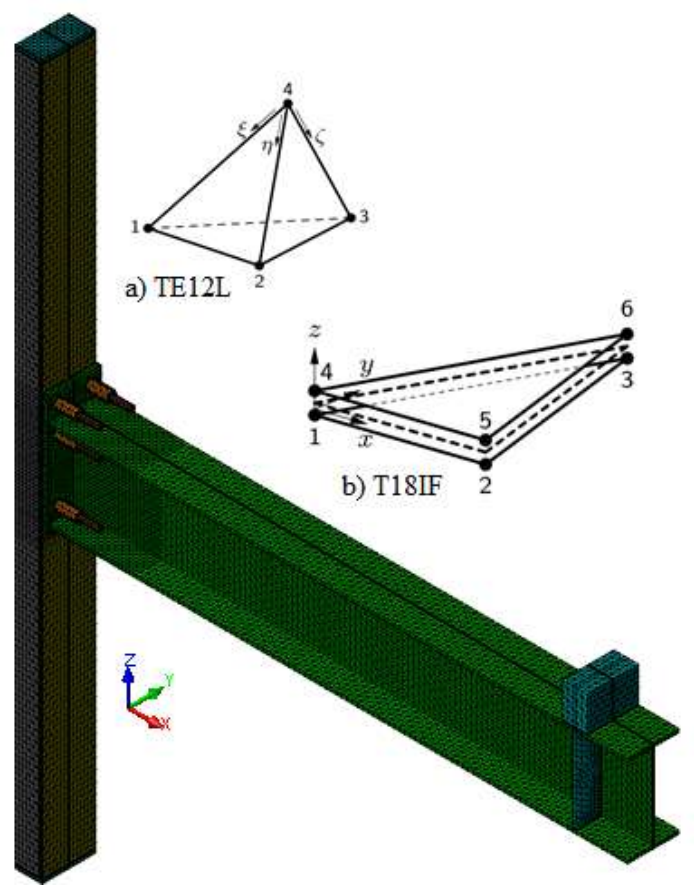

Fonte: Elaborado pela autora.

Os elementos que representam estes materiais apresentam, na região de interface, nós que ocupam o mesmo lugar no espaço. De acordo com as características físicas do modelo experimental, o correto seria a utilização de elementos de contato, mas devido às dificuldades encontradas na introdução de elementos de contato, foi escolhido um elemento de interface 
estrutural. Os elementos de interface possuem a capacidade de representar o comportamento entre dois materiais, relacionando tensão normal e tensão de cisalhamento com o deslizamento relativo nas duas direções. Assim, para representar adequadamente o comportamento da ligação, a rigidez tangencial dos elementos de interface foi reduzida a um valor próximo a zero no local de contato entre o pilar misto e a chapa de topo, entre as barras passantes e a chapa de topo, e entre as porcas e a chapa de topo. Esse artifício foi utilizado para que apenas as forças normais fossem transmitidas.

Para a interface entre o aço e o concreto, foi utilizado o elemento finito de interface T18IF. Este é um elemento de interface com $3+3$ nós que se baseia na interpolação linear para deslocamentos, próprio para o uso entre dois planos em uma configuração tridimensional. Sua escolha se deve à necessidade de compatibilização do grau de interpolação dos elementos finitos utilizados, ou seja, não é possível, no DIANA, empregar elementos de interface com grau de interpolação diferente do elemento finito sólido adjacente, pois não daria para acoplar a malha. As Figuras 5.2 a 5.4 apresentam a interface entre o perfil de aço e o núcleo de concreto, a interface entre a ligação e a estrutura e a interface entre as placas para aplicação das condições de contorno e a estrutura.

Figura 5.2 - Interface aço-concreto e o pilar misto.

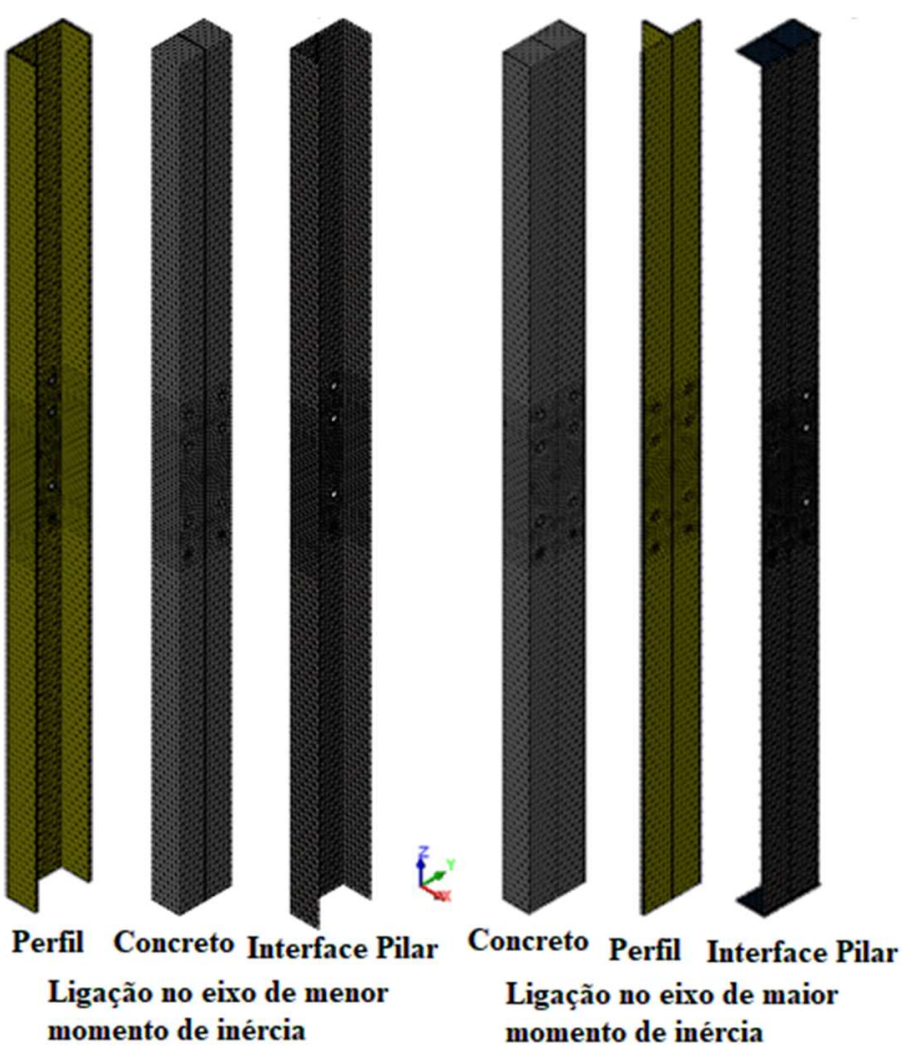

Fonte: Elaborado pela autora. 
Figura 5.3 - Interface da ligação viga-pilar e os elementos de ligação.

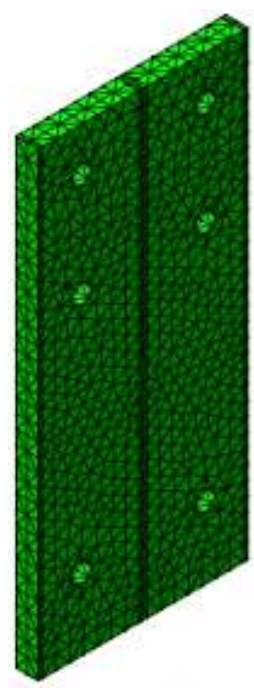

Chapa de Topo

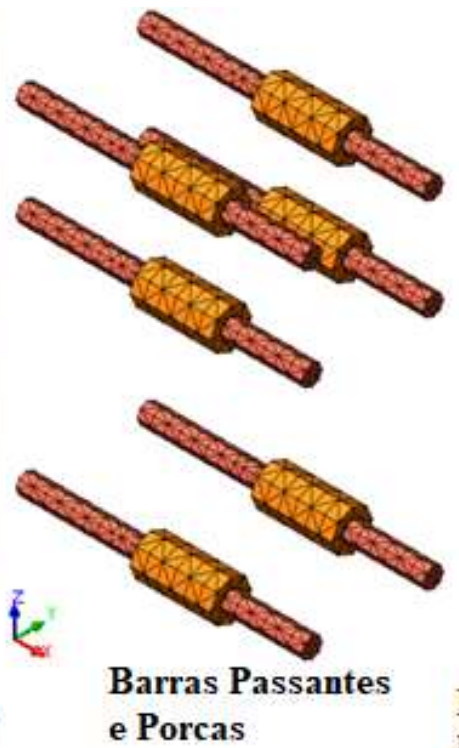

e Porcas
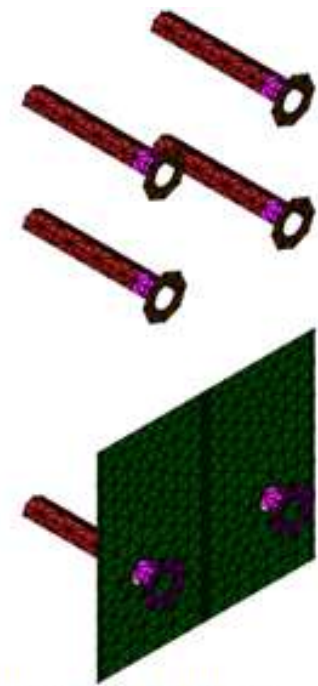

Interface da Barra

Passante, Porca e

Chapa de Topo

Fonte: Elaborado pela autora.

Figura 5.4 - Interface entre as placas para aplicação das condições de contorno e a estrutura.
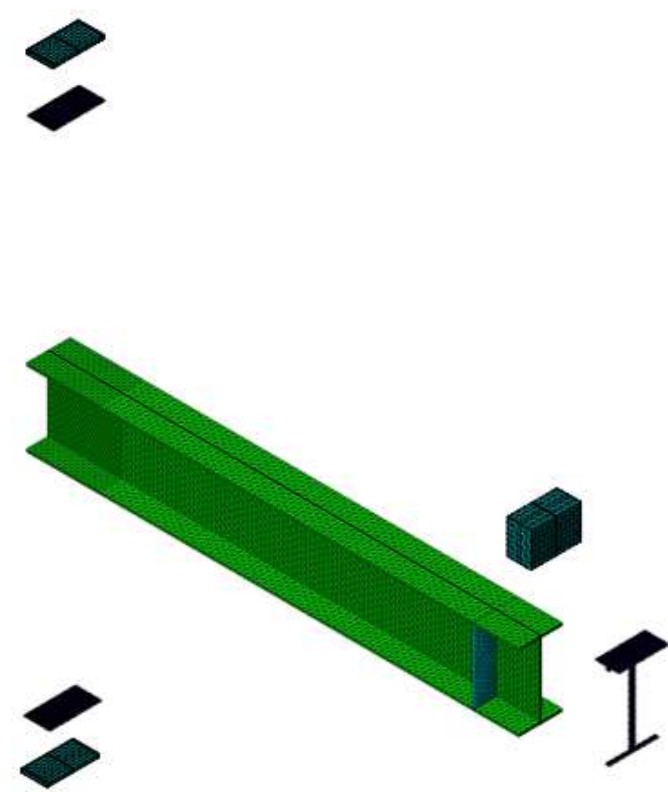

Fonte: Elaborado pela autora.

A geometria utilizada para representação do modelo de ligação viga-pilar foi tridimensional, porém optou-se pela simetria (metade da estrutura), devido às dimensões do modelo que requereria muito tempo para processamento, sem comprometimento dos resultados. As armaduras longitudinais e transversais do pilar misto não foram geradas, já que o objeto de 
estudo era a ligação viga-pilar sem a interrupção do concreto com fibras, portanto, só se considerou uma interface entre o perfil do pilar e o concreto com fibras.

Outra simplificação adotada foi a exclusão das soldas por meio da aderência perfeita entre os nós do perímetro das vigas e os nós das chapas de topo. Essa simplificação tornou o modelo numérico mais rígido, pois nos ensaios experimentais a solda foi um dos modos de falha dos modelos sem a interrupção do concreto, já que no laboratório não se conseguiu uma solda com espessura maior que $6 \mathrm{~mm}$. Foi testada também uma interface linear entre a viga e a chapa de topo para representar a solda e para calibrar as outras interfaces, com isso a capacidade resistente e a rigidez dos modelos numéricos foram próximas às dos modelos experimentais. Porém, decidiu-se excluir a influência da solda na análise paramétrica por meio da aderência perfeita, pois este modo de falha não é o de interesse.

\subsection{Materiais}

Para representar o comportamento dos materiais foram utilizados modelos não lineares. O modelo constitutivo elástico perfeitamente plástico adotado para o aço dos perfis, as chapas de topo e as barras passantes considera o critério de ruptura de Von Mises sem a consideração do encruamento. No modelo de plasticidade ideal, o material não suporta esforços após o escoamento. As curvas tensão versus deformação são normalmente obtidas de ensaios uniaxiais e o comportamento adotado é igual na tração e na compressão. Os valores de resistência ao escoamento utilizados são compatíveis com os obtidos experimentalmente para os perfis, as chapas de topo e as barras passantes (Tabela 4.5).

Já a representação do comportamento do concreto exigiu uma abordagem mais complexa. Foi utilizado o modelo de fissuração distribuída com fissuração fixa baseada na deformação total (Total strain fixed crack model) para representar o comportamento do concreto com fibras. Para definição deste modelo é necessário informar alguns dados de entrada, tais como: as propriedades básicas, como módulo de elasticidade e coeficiente de Poisson; definições para o comportamento a tração, compressão e cisalhamento. Para o comportamento à tração, foi utilizada uma curva exponencial para representar o trecho descendente, cujo valor de energia de fratura $\left(G_{f}\right)$ foi estimado utilizando as expressões do CEB 1990. Na ausência de resultados experimentais do ensaio de fratura, a expressão do CEB-FIP 
(1990) permite estimar o valor de $G_{f}$ para concreto simples com resistência à compressão menor ou igual a $80 \mathrm{Mpa}$ (Equação 5.1).

$$
G_{f}=G_{f 0} \cdot\left(\frac{f_{c m}}{f_{c m}^{0}}\right)^{0,7}\left(N \cdot \frac{m m}{m m^{2}}\right)
$$

Sendo $\mathrm{f}_{\mathrm{cm}}^{0}$ igual a $10 \mathrm{MPa}$ e $G_{f o}$ estimado em função da dimensão máxima do agregado, considerando que a capacidade de absorção de energia é de 10 a 40 vezes maior para o concreto com fibras do que para o concreto simples (BASTOS, 1999). Já a energia de fratura à compressão $\left(G_{c}\right)$ pode ser estimada, segundo Feenstra e Borst (1993), como sendo entre 50 e 100 vezes superior à energia de fratura à tração $\left(G_{f}\right)$ do concreto estudado.

Segundo Pereira (2017), a fim de melhorar a representatividade do modelo numérico, podem ser realizadas modificações na curva parabólica tensão-deformação do concreto à compressão de modo que os resultados numéricos fiquem bem ajustados aos resultados experimentais. Para isto, o comportamento do concreto foi representado por uma curva multilinear. Esta nova curva tensão-deformação foi construída utilizando os valores de resistência à compressão e módulo de elasticidade obtidos experimentalmente (Tabela 4.5). A curva multilinear tensão-deformação adotada possui os pontos mostrados na Tabela 5.1 e se aproxima da curva obtida nos ensaios de caracterização do concreto (Figura 5.5).

Tabela 5.1 - Curva tensão-deformação do concreto com fibras.

Fonte: Elaborado pela autora.

\begin{tabular}{|c|c|}
\hline Deformação \%o & Tensão (MPa) \\
\hline 0,1 & 3,16 \\
\hline 0,2 & 6,36 \\
\hline 0,4 & 12,60 \\
\hline 0,6 & 17,58 \\
\hline 0,8 & 22,19 \\
\hline 1,0 & 26,10 \\
\hline 1,5 & 33,40 \\
\hline 1,7 & 35,90 \\
\hline 2,0 & 38,12 \\
\hline 2,2 & 39,52 \\
\hline 2,5 & 40,54 \\
\hline 2,7 & 41,24 \\
\hline 3,0 & 41,42 \\
\hline 7,0 & 30,00 \\
\hline
\end{tabular}


Figura 5.5 - Curva multilinear do concreto com fibras.

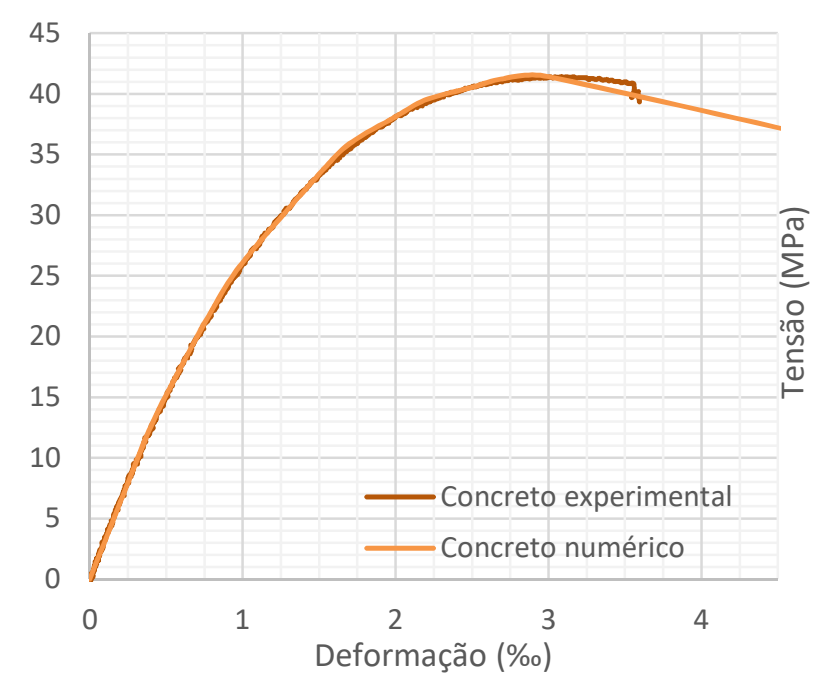

Fonte: Elaborado pela autora.

Optou-se por representar a interface entre os elementos por um modelo de interface linear, pois nenhuma das interfaces geradas foi o modo de falha observado no ensaio experimental. Os parâmetros que caracterizam este modelo são os módulos de rigidez normal $(\mathrm{Kn})$ e transversal $(\mathrm{Kt})$. Os valores de rigidez transversal e rigidez normal foram obtidos calibrando cada interface com o resultado experimental (Tabela 5.2). Para as interfaces entre a placa de aplicação de carregamento e o pilar misto, e entre o enrijecedor e a viga, foram adotados valores bastante elevados de rigidez transversal e normal, isto porque a placa e o enrijecedor foram soldados ao perfil de aço. Já a interface entre as chapas de topo e o pilar misto foi gerada apenas na região comprimida da chapa de topo pela viga, e entre as barras passantes e a estrutura apenas na metade da superfície das barras, uma solução adotada para garantir a transferência de forças entre os elementos estruturais.

Tabela 5.2 - Valores adotados de rigidezes normal e tangencial para as interfaces.

\begin{tabular}{|c|c|c|}
\hline Interface & $\mathrm{Kn}\left(\mathrm{N} / \mathbf{m m}^{3}\right)$ & $\mathrm{Kt}\left(\mathrm{N} / \mathrm{mm}^{3}\right)$ \\
\hline $\begin{array}{c}\text { placa - pilar } \\
\text { placa - viga } \\
\text { enrijecedor - viga }\end{array}$ & 1000000000 & 1000000000 \\
\hline barra - concreto & 100 & 10 \\
\hline porca - chapa tracionada & 10000 & 0,001 \\
\hline porca - chapa comprimida & 1 & 0,001 \\
\hline pilar - chapa comprimida & 10000 & 0,001 \\
\hline perfil - concreto & 10000 & 100 \\
\hline barra - chapa & 1000 & 0,001 \\
\hline
\end{tabular}

Fonte: Elaborado pela autora. 


\subsection{Condições de Contorno e Técnicas de Solução}

No modelo numérico, placas constituídas por material altamente rígido foram utilizadas com a função de distribuir o carregamento aplicado. Com base no esquema utilizado nos ensaios nos modelos físicos, optou-se não só pela imposição de deslocamentos unitários na direção z, aplicados nos nós da placa rígida posicionada sobre a viga de aço, mas também pela aplicação de força concentrada total de $200 \mathrm{kN}$ (metade do pilar) nos nós da placa rígida posicionada na extremidade do pilar misto (Figura 5.6). Com relação às condições de contorno adotadas, os deslocamentos foram restringidos em x e $\mathrm{z}$ na base do pilar, em x na face de simetria e também em y na viga a uma distância de um metro da ligação.

Figura 5.6 - Condições de contorno dos modelos numéricos.

Fonte: Elaborado pela autora.

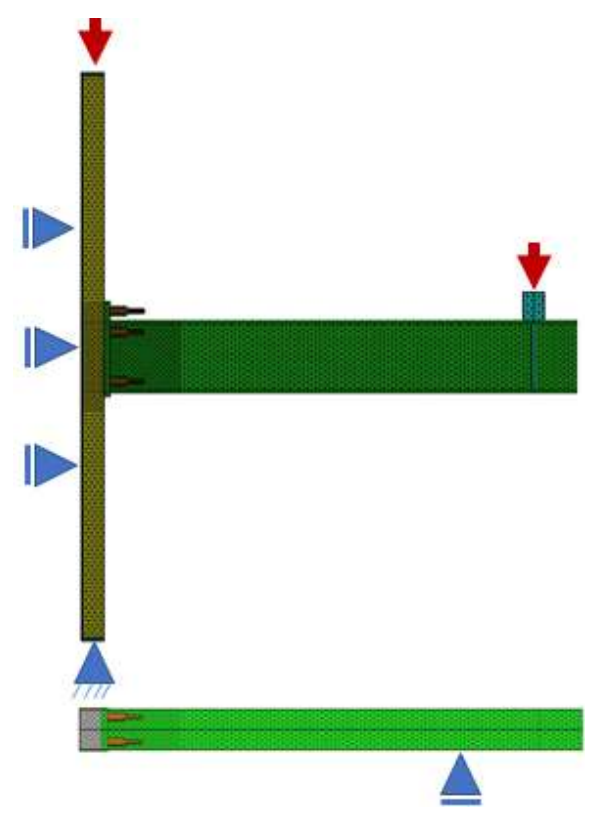

A técnica de solução adotada foi a de Quasi-Newton, com critério de convergência de deslocamento. A tolerância assumida foi de $10^{-2}$. A fim de melhorar a convergência do processo e reduzir o tempo de processamento, foi habilitado ainda o procedimento 'Line Search'. O deslocamento foi aplicado em até 50 passos de $0,7 \mathrm{~mm}$ e como critério de parada considerouse o escoamento da região tracionada da ligação e a perda de convergência do modelo.

\subsection{Validação dos Modelos Definitivos sem Interrupção do Concreto}




\subsubsection{Validação da Tipologia 4}

Para a análise numérica das ligações estudadas experimentalmente foram utilizados dados de força aplicada, deslocamento vertical da viga e deformações geradas nos elementos de aço, tais como, nas chapas de topo, nas barras passantes e nas mesas das vigas. Ressalta-se que serão apresentados os resultados numéricos tanto para aderência perfeita entre a chapa de topo e a viga de aço quanto para uma interface linear entre a chapa de topo e a viga de aço, adotando o valor de $500 \mathrm{~N} / \mathrm{mm}^{3}$ para as rigidezes normal e tangencial. Os resultados numéricos referentes a essa interface linear entre a chapa de topo e a viga de aço são para demonstrar a calibração do modelo numérico e das outras interfaces consideradas. A configuração deformada dos modelos numéricos e as tensões principais não serão abordadas, pois uma atualização do programa DIANA 9.6 para DIANA 10.4, durante os últimos meses, bloqueava a utilização do pós-processador Midas $\mathrm{Fx}+$, e assim, a leitura completa dos resultados.

A Figura 5.7 apresenta as curvas Força Média vs. Deslocamento Vertical obtidas pelos ensaios experimentais e pelas simulações numéricas para Tipologia 4. Nos modelos numéricos a força equivalente foi obtida por meio dos deslocamentos unitários aplicados na placa sobre a viga e o deslocamento vertical foi obtido no mesmo ponto medido experimentalmente pelos transdutores (T1 e T8) nas extremidades das vigas. Observa-se que o modelo numérico com interface linear entre a chapa de topo e a viga de aço (Num_Interface) consegue reproduzir satisfatoriamente a evolução dos deslocamentos em função da força aplicada, a rigidez inicial e a capacidade de deformação em relação ao modelo experimental (T1-T8).

Figura 5.7 - Calibração do modelo numérico pela curva de força versus deslocamento vertical.

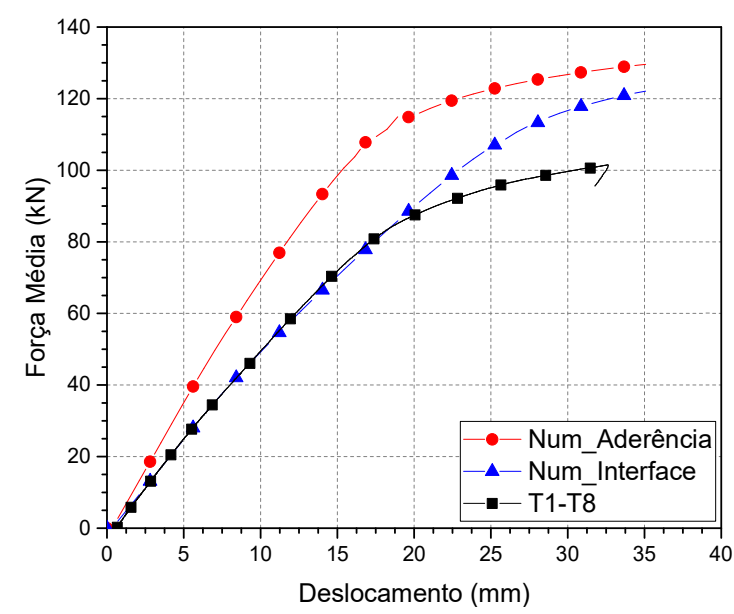

Fonte: Elaborado pela autora. 
Já o modelo numérico com aderência perfeita (Num_Aderência) entre a chapa de topo e a viga de aço apresentou um comportamento mais rígido que do modelo experimental, como já era esperado, porém, considerado para eliminar a influência da solda. Nota-se que os valores de força máxima obtidos nos modelos numéricos são próximos ao valor obtido experimentalmente com divergência na ordem de $20 \%$ a $30 \%$. Isto pode estar relacionado com a forma de aplicação do carregamento na viga. Além disso, as diferenças quantitativas entre os resultados numéricos e os experimentais advêm de diversos fatores que não podem ser controlados na totalidade, tais como, imperfeições iniciais, tensões residuais, contato entre os elementos, variações nas propriedades dos materiais (pequena amostra), simplificações adotadas na geometria como a eliminação da solda e hipóteses assumidas na modelagem como interface linear. Cabe salientar que dentro das limitações da modelagem, os resultados numéricos devem ser corretamente interpretados.

Ainda com o objetivo de avaliar a representatividade dos modelos numéricos, as deformações obtidas nos modelos numéricos são comparadas com os resultados obtidos experimentalmente. Verificaram-se, no modelo numérico, as deformações nas mesmas posições que foram medidas experimentalmente para as barras passantes, as chapas de topo, as mesas das vigas e o concreto de revestimento. Os resultados obtidos em função da força média sobre a viga são apresentados nas Figuras 5.8 e 5.9. Constata-se que há boa correlação entre os resultados experimentais e numéricos para todos os pontos de deformação medidos pelos extensômetros, seja no aço ou no concreto, principalmente no trecho linear inicial. Portanto, as hipóteses assumidas para o concreto e para o aço obtêm uma boa correspondência entre os resultados numéricos e experimentais em termos de deformações.

Com base nos resultados abordados da modelagem numérica, considera-se que o modelo numérico com interface linear entre a chapa de topo e a viga de aço está validado e é representativo do comportamento experimental. Nota-se também, no modelo numérico com aderência perfeita, um comportamento mais rígido da chapa de topo do que observado experimentalmente devido à eliminação da solda, mas há uma tendência de plastificação. Apesar das diferenças entre os resultados numéricos do modelo com aderência perfeita e os resultados experimentais, indica-se a possibilidade de se utilizar a modelagem proposta com a eliminação da solda para estudos paramétricos, visto a sua capacidade em representar as variações do comportamento das ligações com a mudança de geometria e de resistência. Portanto, para fins de representação da curva Força Média x Deslocamento Vertical considerase o modelo numérico representativo do comportamento experimental. 
Figura 5.8 - Deformações de chapa de topo e barras passantes nos modelos numéricos.

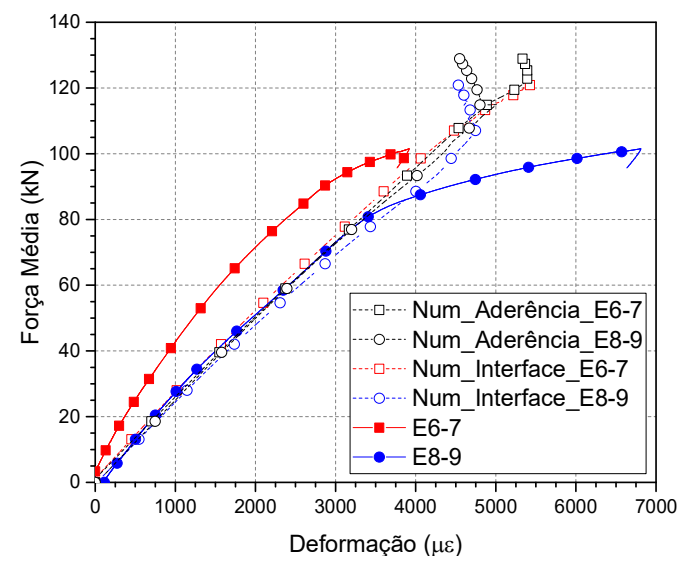

a) Deformações (Ex) nas barras passantes.

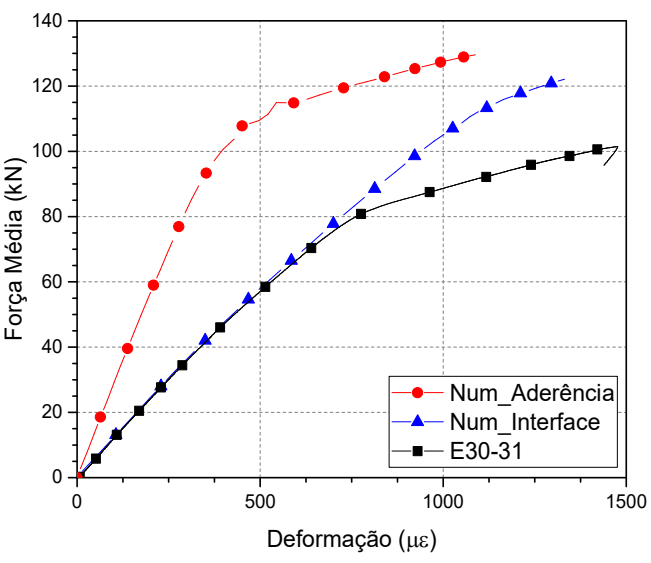

b) Deformação (Ey) na chapa de topo.

Fonte: Elaborado pela autora.

Figura 5.9-Deformações das vigas e do concreto nos modelos numéricos.

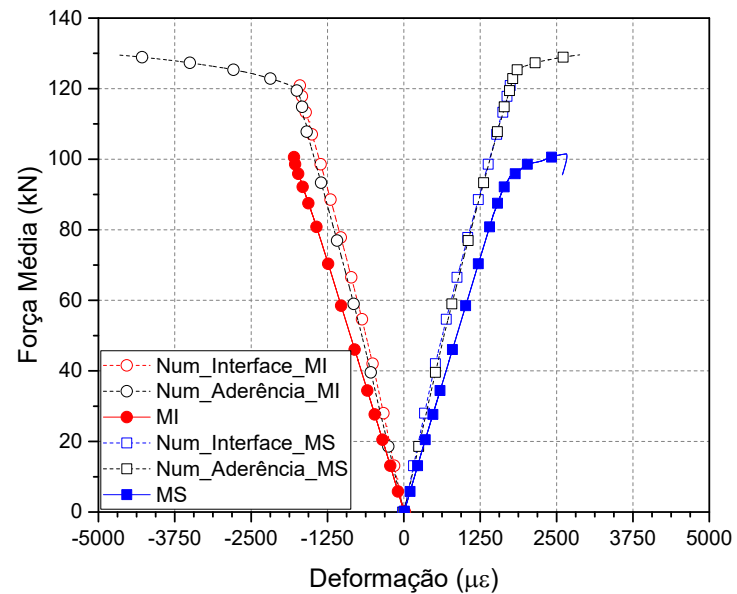

a) Deformações (Ex) nas mesas superior e inferior das vigas.

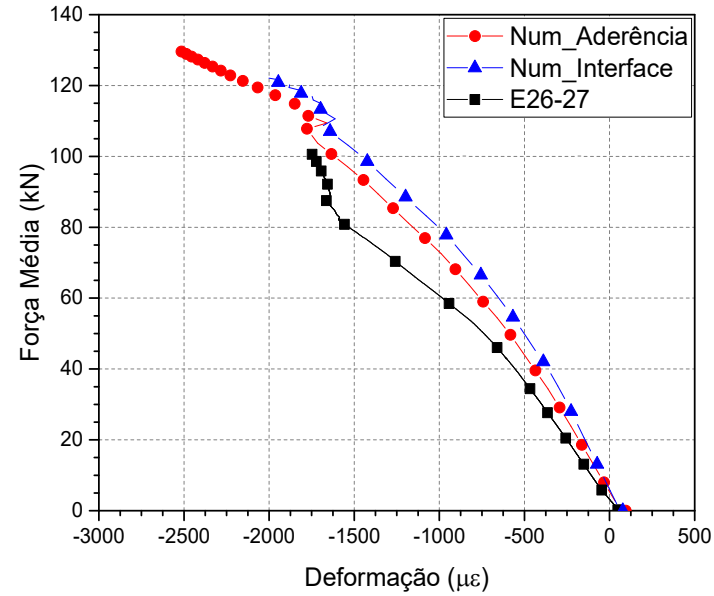

b) Deformação (Ex) no concreto de revestimento com fibras.

Fonte: Elaborado pela autora.

\subsubsection{Validação da Tipologia 5}

Para a análise numérica das ligações estudadas experimentalmente foram utilizados dados de força aplicada, deslocamento vertical da viga e deformações geradas nos elementos de aço, tais como, nas chapas de topo, nas barras passantes e nas mesas das vigas. Ressalta-se que serão apresentados os resultados numéricos tanto para aderência perfeita entre a chapa de topo e a viga de aço quanto para uma interface linear entre a chapa de topo e a viga de aço, 
adotando os valores de 100 e de $500 \mathrm{~N} / \mathrm{mm}^{3}$ para as rigidezes normal e tangencial, respectivamente. Observa-se que a rigidez normal da interface é 1/5 do valor utilizado para Tipologia 4, pois houve ruptura parcial da solda durante este ensaio. Os resultados numéricos referentes a essa interface linear entre a chapa de topo e a viga de aço são para demonstrar a calibração do modelo numérico e das outras interfaces consideradas.

A Figura 5.10 apresenta as curvas Força Média vs. Deslocamento Vertical obtidas pelos ensaios físicos e pelas simulações numéricas para Tipologia 5. Nos modelos numéricos a força equivalente foi obtida por meio dos deslocamentos unitários aplicados na placa sobre a viga e o deslocamento vertical foi obtido no mesmo ponto medido experimentalmente pelos transdutores (T1 e T8) nas extremidades das vigas. Observa-se uma boa correlação entre os resultados experimentais e os numéricos para o modelo numérico com interface linear entre a chapa de topo e a viga de aço (Num_Interface), na representação da força máxima, da rigidez inicial e na capacidade de deformação.

Figura 5.10 - Calibração do modelo numérico pela curva de força versus deslocamento vertical.

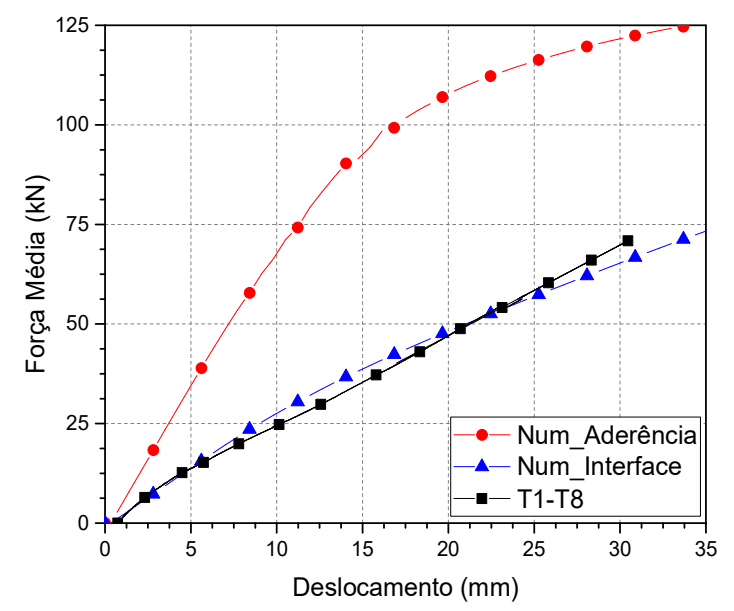

Fonte: Elaborado pela autora.

Já o modelo numérico com aderência perfeita (Num_Aderência) entre a chapa de topo e a viga de aço apresentou um comportamento bem mais rígido que do modelo experimental, como já era esperado, porém, considerado para eliminar a influência da solda. Nota-se que o valor de força máxima obtido para este modelo numérico é maior do que o valor obtido experimentalmente com divergência na ordem de 65\%. Mais uma vez, as diferenças quantitativas entre os resultados numéricos e os experimentais advêm de diversos fatores que não podem ser controlados na totalidade, tais como, imperfeições iniciais, tensões residuais, contato entre os elementos, variações nas propriedades dos materiais (pequena amostra), adensamento e acabamento do concreto, simplificações adotadas na geometria como a 
eliminação da solda e hipóteses assumidas na modelagem como interface linear. Cabe salientar que dentro das limitações da modelagem, os resultados numéricos devem ser corretamente interpretados.

Novamente com o objetivo de avaliar a representatividade dos modelos numéricos, as deformações obtidas nos modelos numéricos são comparadas com os resultados obtidos experimentalmente. Verificaram-se, no modelo numérico, as deformações nas mesmas posições que foram medidas experimentalmente para as barras passantes, as chapas de topo e as mesas das vigas. Os resultados obtidos em função da força média sobre a viga são apresentados na Figura 5.11. Constata-se que há boa correlação entre os resultados experimentais e numéricos para os pontos de deformação medidos pelos extensômetros, exceto na chapa de topo, principalmente no trecho linear inicial.

Figura 5.11 - Deformações dos elementos de aço nos modelos numéricos.

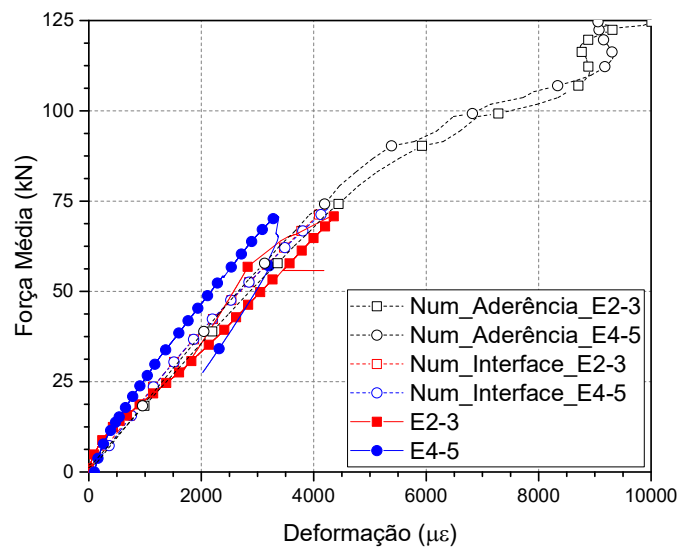

a) Deformações (Ex) nas barras passantes.

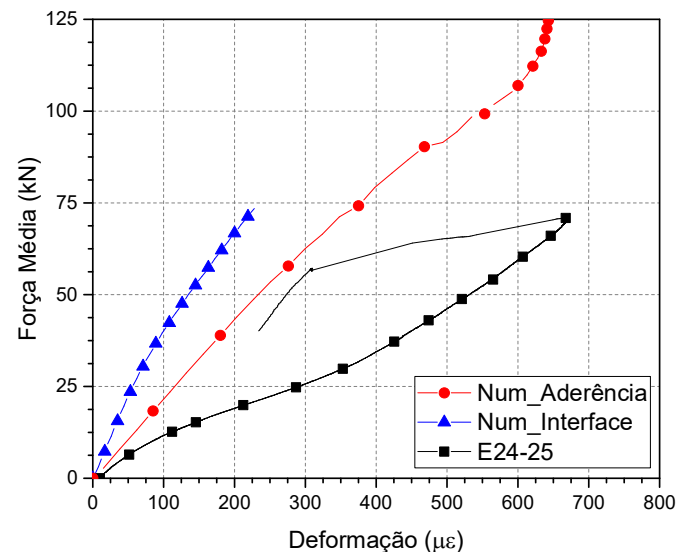

b) Deformação (Ez) na chapa de topo.

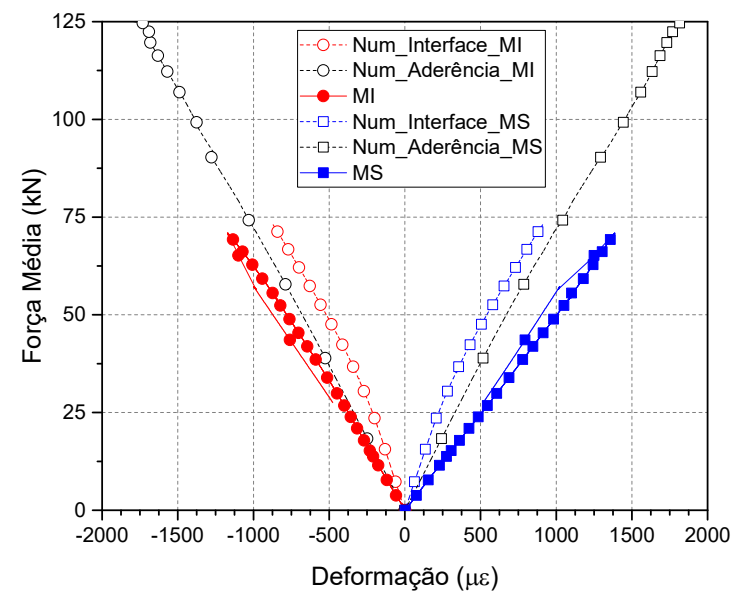

c) Deformações (Ex) nas mesas superior e inferior das vigas.

Fonte: Elaborado pela autora. 


\section{4 | SIMULAÇÃO NUMÉRICA}

Observa-se para os modelos numéricos um comportamento mais rígido da chapa de topo do que observado experimentalmente. É difícil precisar a razão desta variação uma vez que vários fatores podem modificar os resultados; uma possível explicação está relacionada à malha gerada da chapa de topo que não foi muito representativa. Com base nos resultados abordados da modelagem numérica, considera-se que o modelo numérico com interface linear entre a chapa de topo e a viga de aço está validado e retratou de maneira satisfatória o comportamento do modelo físico. Apesar das diferenças encontradas entre os resultados numéricos do modelo com aderência perfeita e os resultados experimentais, indica-se a possibilidade de se utilizar a modelagem proposta com a exclusão das soldas para estudos paramétricos, visto que a influência desse parâmetro sob a resposta dos modelos é uniforme e pode ser desprezada em análises comparativas entre resultados numéricos. Portanto, para fins de representação da curva Força Média x Deslocamento Vertical considera-se o modelo numérico representativo do comportamento experimental.

\subsection{Análise Paramétrica}

\subsubsection{Análise Paramétrica da Tipologia 4}

A partir da representatividade do modelo numérico em relação ao experimental, foi possível ampliar as conclusões, permitindo o entendimento mais completo do modelo estudado. O comportamento estrutural de ligações viga-pilar misto depende de vários parâmetros, entretanto não puderam ser analisados no programa experimental devido à falta de recursos e de tempo. Com o objetivo de avaliar a influência de outros parâmetros que possam ser relevantes na definição do comportamento estrutural das ligações viga-pilar misto sem interrupção do concreto de revestimento foi desenvolvida uma análise paramétrica. Os modelos do estudo paramétrico seguem a mesma descrição do modelo utilizado na calibração, isto é, mesmo tipo de elemento finito, propriedades mecânicas dos materiais e das interfaces, aderência perfeita entre a chapa de topo e a viga de aço, condições de contorno e de carregamento. Para englobar todos os parâmetros, ao todo foram processados 144 modelos numéricos, variando:

- Espessura da chapa de topo: 13, 16 (valor experimental), 19 e 22 mm;

- Diâmetro das barras passantes: 13, 15 (valor experimental), 19 e 22 mm; 
- Resistência ao escoamento do aço das barras passantes: $650 \mathrm{MPa}$ e $900 \mathrm{MPa}$ (valor experimental);

- Resistência ao escoamento do aço da chapa de topo: $350 \mathrm{MPa}, 415 \mathrm{MPa}$ (valor experimental) e $450 \mathrm{MPa}$;

- Resistência ao escoamento do aço da viga: 365 MPa (valor experimental), 400 $\mathrm{MPa}$ e $450 \mathrm{MPa}$;

- Carregamento do pilar (metade devido à simetria): $200 \mathrm{kN}$ (valor experimental), $400 \mathrm{kN} \mathrm{e} 600 \mathrm{kN}$;

- Vão: 1000 mm e 1500 mm (valor experimental).

Os parâmetros foram analisados em função dos diâmetros das barras passantes e das espessuras da chapa de topo para uma força média referente a um deslocamento vertical máximo de $35 \mathrm{~mm}$, no qual todos os modelos estavam em regime plástico e com rotações próximas de $20 \mathrm{mrad}$. Segundo Tristão (2006), a resistência da ligação pode ser definida para uma rotação de 20 mrad e a capacidade rotacional da ligação pode ser definida quando o momento da ligação reduzir $80 \%$ do seu momento resistente ou quando a ligação atingir 30 mrad. O modelo de referência é a chapa de topo com espessura de $16 \mathrm{~mm}$ e resistência ao escoamento (fy) de $415 \mathrm{MPa}$, a barra passante com diâmetro de $15 \mathrm{~mm}$ (B15) e resistência ao escoamento (fy) de $900 \mathrm{MPa}$, a viga com resistência ao escoamento (fy) de $365 \mathrm{MPa}$, o carregamento do pilar de 200 kN (F200) e o vão de 1500 mm (v1500).

\section{a) Resistência ao Escoamento do Aço da Barra Passante}

Para comparar o comportamento das ligações foi gerado um gráfico de Força Média vs. Espessura da Chapa de Topo, variando os diâmetros das barras passantes analisadas em 13, 15, 19 e $22 \mathrm{~mm}$ e sua resistência ao escoamento em 650 e $900 \mathrm{MPa}$, como mostra a Figura 5.12. Analisando as curvas, é possível constatar que o diâmetro das barras passantes e sua resistência ao escoamento possuem importante influência sobre o comportamento desse tipo de ligação para pequenos diâmetros (13 e $15 \mathrm{~mm}$ ). Além disso, para a espessura da chapa de topo e o diâmetro das barras passantes de $13 \mathrm{~mm}$, os resultados aparentemente ficaram distorcidos devido à malha da chapa de topo na direção da espessura, pois somente para essa espessura, a chapa não foi dividida na direção x. Essa teoria é plausível recordando o ensaio piloto, pois 
uma pequena espessura da chapa de topo influenciou a capacidade resistente da ligação e isso não foi visto nos modelos numéricos.

Figura 5.12 - Influência das barras passantes da Tipologia 4.

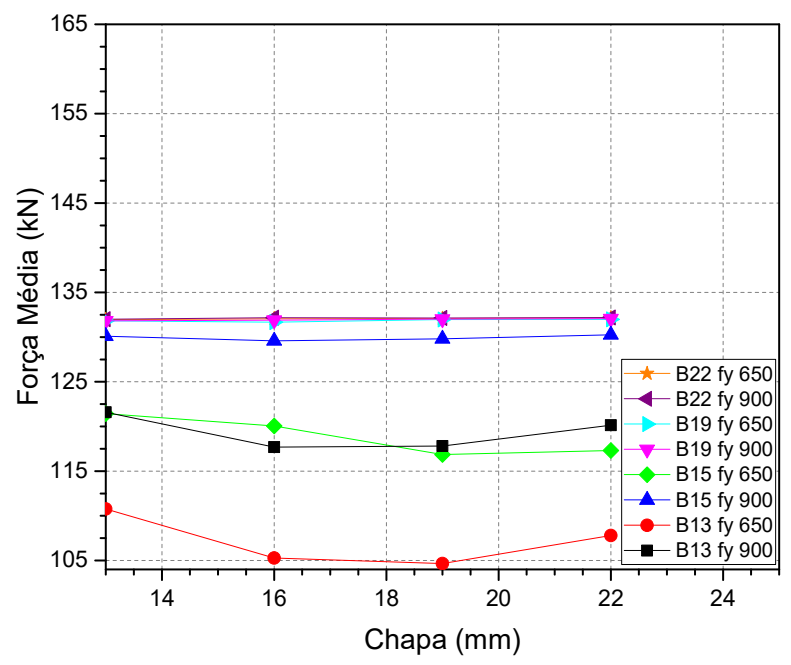

Fonte: Elaborado pela autora.

Os resultados obtidos na simulação numérica para as barras passantes de $13 \mathrm{~mm}$ de diâmetro indicaram uma redução da capacidade resistente por volta de $10 \%$ quando comparado ao comportamento do modelo de referência (B15 fy 900). Em relação ao modelo de referência, quando diminui a resistência ao escoamento do aço da barra passante para $650 \mathrm{MPa}$, há também uma redução de $10 \%$ da capacidade resistente, entretanto a capacidade resistente ainda é superior ao modelo experimental com interrupção do concreto na ligação e parafusos A325. Quando o diâmetro das barras passantes aumentou para $19 \mathrm{~mm}$, independente da resistência ao escoamento do aço da barra passante e da espessura da chapa de topo, o comportamento da ligação foi semelhante ao modelo de referência, indicando que outro parâmetro limita a capacidade resistente da ligação. Como conclusão sobre a influência do diâmetro das barras passantes e sua resistência ao escoamento na capacidade resistente da ligação analisada, podese dizer que o ganho de capacidade resistente é influenciado com o aumento dessas variáveis.

\section{b) Resistência ao Escoamento do Aço da Chapa de Topo}

Comportamento global das ligações viga-pilar misto, analisando-se as variações da deformabilidade da chapa de topo com relação às barras passantes, apresentou variações quanto à capacidade resistente ilustradas pela Figura 5.13. Mantendo-se as barras passantes com diâmetro pequeno (13 e $15 \mathrm{~mm}$ ) e constante, o aumento da espessura da chapa de topo e o 
aumento da sua resistência ao escoamento ocasionam um pequeno aumento da capacidade resistente da ligação até o limite da capacidade resistente das barras passantes, devido à eliminação do "efeito alavanca", e até o limite da capacidade resistente da viga. Portanto, observa-se ligeiramente a mudança na linha de plastificação na medida em que a espessura da chapa de topo e/ou a sua resistência ao escoamento aumentam, ou seja, na medida em que a deformabilidade da chapa de topo torna-se pequena com relação à deformabilidade das barras passantes. Porém, isso é verificado para pequenos diâmetros, pois a partir do diâmetro de 19 $\mathrm{mm}$ da barra passante, outro parâmetro limita a capacidade resistente da ligação. Além disso, a espessura da chapa de topo apresentou maior influência sobre a capacidade resistente da ligação do que a sua resistência ao escoamento.

Figura 5.13 - Influência da chapa de topo da Tipologia 4.

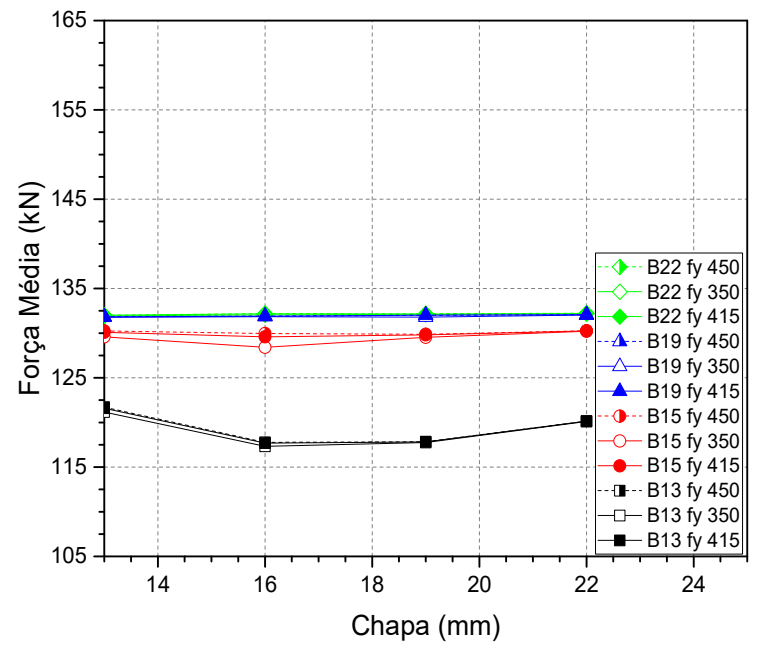

Fonte: Elaborado pela autora.

\section{c) Resistência ao Escoamento do Aço da Viga}

A influência da resistência ao escoamento do aço da viga foi avaliada com três valores de resistência ao escoamento do aço: $365 \mathrm{MPa}$ (valor experimental), $400 \mathrm{MPa}$ e $450 \mathrm{MPa}$. Os resultados obtidos nestas simulações são apresentados na Figura 5.14. Como esperado, nota-se que quanto maior a resistência ao escoamento do aço da viga maior o valor de força máxima obtida e percebe-se que a relação entre o valor de resistência ao escoamento do aço da viga e a força máxima atingida é aproximadamente linear. Foi verificado que um aumento de aproximadamente $25 \%$ na resistência ao escoamento do aço (de fy $=365$ para fy $=450 \mathrm{MPa}$ ) implica em um aumento médio de $15 \%$ na força máxima atingida pelas ligações analisadas. A 
influência é maior para grandes diâmetros (19 e $22 \mathrm{~mm}$ ). Assim, conclui-se que o aumento da resistência do aço da viga tem uma influência significativa na capacidade resistente da ligação, pois como visto na investigação experimental, atinge-se o momento de plastificação da viga.

Figura 5.14 - Influência da resistência ao escoamento do aço da viga da Tipologia 4.

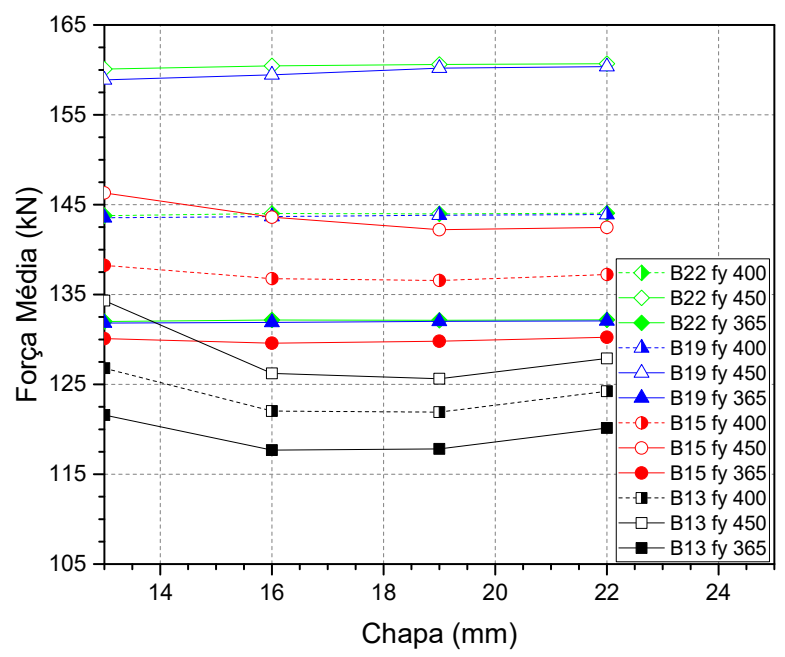

Fonte: Elaborado pela autora.

\section{d) Vão}

Foi realizada uma análise para o vão adotado no modelo de ligação. No modelo de referência foi adotado um vão de $1500 \mathrm{~mm}$ e para o estudo da influência desse parâmetro foi simulado também um vão de $1000 \mathrm{~mm}$. Os resultados das simulações são apresentados na Figura 5.15 e aparentemente, as diferenças encontradas entre as curvas são referentes ao braço de alavanca, ou seja, para manter constante o momento fletor atuante na ligação, quando se reduz o vão, aumenta-se a força que pode ser aplicada. Porém, percebe-se que a capacidade resistente da viga limita a capacidade resistente da ligação para um vão de $1000 \mathrm{~mm}$, pois independente da espessura da chapa de topo e do diâmetro das barras passantes, a capacidade resistente se mantém constante, exceto para um pequeno diâmetro de $13 \mathrm{~mm}$ da barra passante. 
Figura 5.15 - Influência do vão da Tipologia 4.

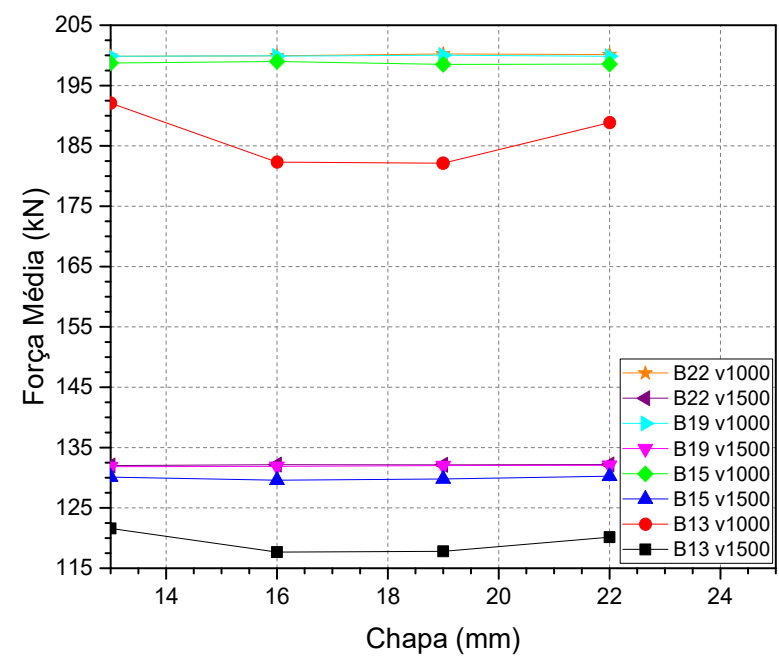

Fonte: Elaborado pela autora.

\section{e) Carregamento do Pilar}

Na Figura 5.16 estão mostrados os resultados da análise paramétrica do carregamento do pilar. Os modelos numéricos com um maior carregamento do pilar apresentaram menor capacidade resistente, pois há uma combinação do carregamento do pilar e do carregamento da viga na ligação, mas as diferenças encontradas foram insignificantes na ordem de 1\%. Observase que a partir do diâmetro de $19 \mathrm{~mm}$ das barras passantes, não há variação da capacidade resistente em função do carregamento do pilar.

Figura 5.16 - Influência do carregamento do pilar da Tipologia 4.

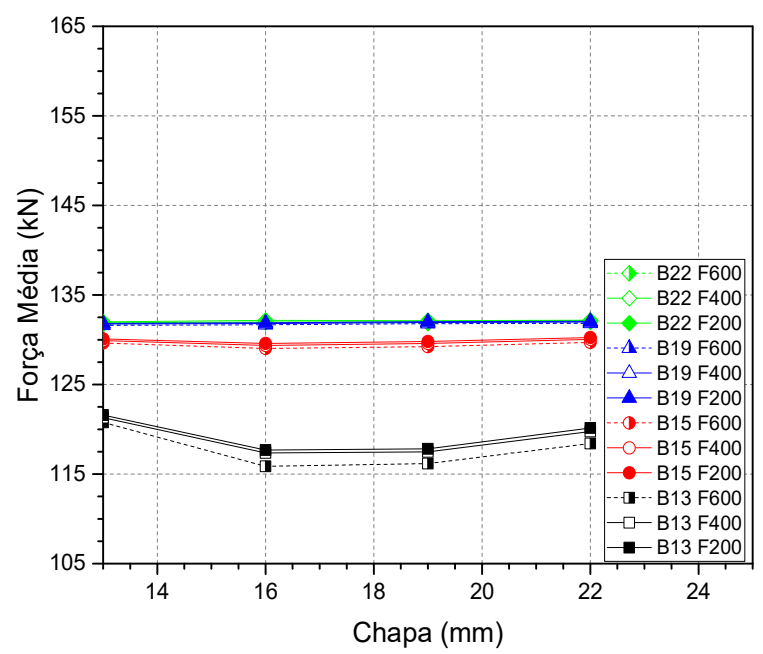

Fonte: Elaborado pela autora. 


\subsubsection{Análise Paramétrica da Tipologia 5}

A partir da representatividade do modelo numérico em relação ao experimental, foi possível ampliar as conclusões, permitindo o entendimento mais completo do modelo estudado. O comportamento estrutural de ligações viga-pilar misto depende de vários parâmetros, entretanto não puderam ser analisados no programa experimental devido à falta de recursos e de tempo. Com o objetivo de avaliar a influência de outros parâmetros que possam ser relevantes na definição do comportamento estrutural das ligações viga-pilar misto sem interrupção do concreto de revestimento foi desenvolvida uma análise paramétrica. Os modelos do estudo paramétrico seguem a mesma descrição do modelo utilizado na calibração, isto é, mesmo tipo de elemento finito, propriedades mecânicas dos materiais e das interfaces, aderência perfeita entre a chapa de topo e a viga de aço, condições de contorno e de carregamento. Para englobar todos os parâmetros, ao todo foram processados 128 modelos numéricos, variando:

- Espessura da chapa de topo: 13, 16 (valor experimental), 19 e $22 \mathrm{~mm}$;

- Diâmetro das barras passantes: 13, 15 (valor experimental), 19 e 22 mm;

- Resistência ao escoamento do aço das barras passantes: $650 \mathrm{MPa}$ e $900 \mathrm{MPa}$ (valor experimental);

- Resistência ao escoamento do aço da chapa de topo: $350 \mathrm{MPa}, 415 \mathrm{MPa}$ (valor experimental) e $450 \mathrm{MPa}$;

- Resistência ao escoamento do aço da viga: $365 \mathrm{MPa}$ (valor experimental), 400 $\mathrm{MPa}$ e $450 \mathrm{MPa}$;

- Carregamento do pilar (metade devido à simetria): $200 \mathrm{kN}$ (valor experimental), $400 \mathrm{kN}$ e $600 \mathrm{kN}$;

Os parâmetros foram analisados em função dos diâmetros das barras passantes e das espessuras da chapa de topo para uma força média referente a um deslocamento vertical máximo de $35 \mathrm{~mm}$, no qual todos os modelos estavam em regime plástico e com rotações próximas de $20 \mathrm{mrad}$. O modelo de referência é a chapa de topo com espessura de $22 \mathrm{~mm}$ e resistência ao escoamento (fy) de $415 \mathrm{MPa}$, a barra passante com diâmetro de $15 \mathrm{~mm}$ (B15) e resistência ao escoamento (fy) de $900 \mathrm{MPa}$, a viga com resistência ao escoamento (fy) de 365 MPa e o carregamento do pilar de $200 \mathrm{kN}$ (F200). 


\section{a) Resistência ao Escoamento do Aço da Barra Passante}

Para comparar o comportamento das ligações foi gerado um gráfico de Força Média vs. Espessura da Chapa de Topo, variando os diâmetros das barras passantes analisadas em 13, 15, 19 e $22 \mathrm{~mm}$ e sua resistência ao escoamento em 650 e $900 \mathrm{MPa}$, como mostra a figura 5.17. Analisando as curvas, é possível constatar que o diâmetro das barras passantes e sua resistência ao escoamento possuem importante influência sobre o comportamento desse tipo de ligação e deve ser dimensionado corretamente de acordo com as características dos elementos da ligação.

Figura 5.17 - Influência das barras passantes da Tipologia 5.

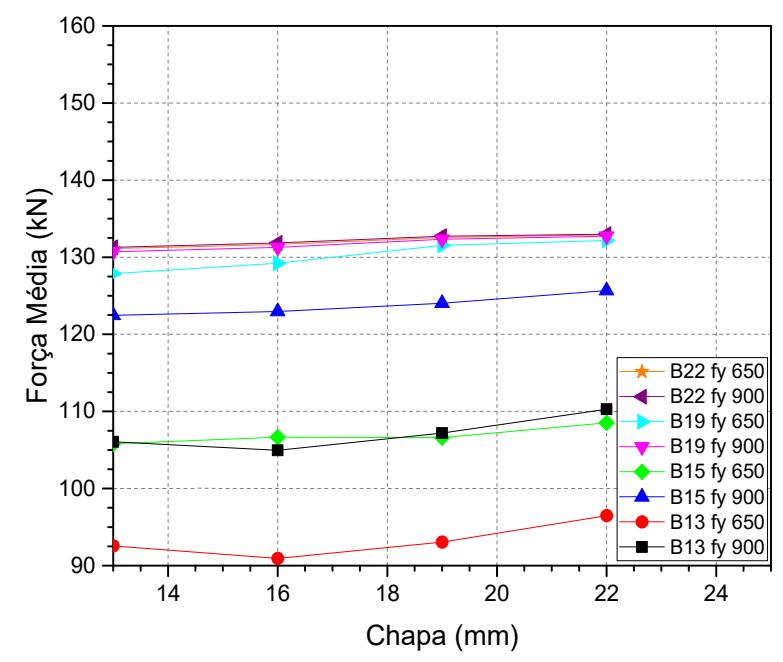

Fonte: Elaborado pela autora.

Os resultados obtidos na simulação numérica para as barras passantes de $13 \mathrm{~mm}$ de diâmetro indicaram uma queda da capacidade resistente por volta de $15 \%$ quando comparado ao comportamento do modelo de referência (B15 fy 900). Em relação ao modelo de referência, quando diminui a resistência ao escoamento do aço da barra passante para $650 \mathrm{MPa}$, há também uma redução de $15 \%$ da capacidade resistente. Quando o diâmetro das barras passantes aumentou para $19 \mathrm{~mm}$, independente da resistência ao escoamento do aço da barra passante e da espessura da chapa de topo, o comportamento da ligação se mantém aproximadamente constante, indicando que outro parâmetro limita a capacidade resistente da ligação. Como conclusão sobre a influência do diâmetro das barras passantes e sua resistência ao escoamento na capacidade resistente da ligação analisada, pode-se dizer que o ganho de capacidade resistente é influenciado com o aumento dessas variáveis. 


\section{b) Resistência ao Escoamento do Aço da Chapa de Topo}

Comportamento global das ligações viga-pilar misto, analisando-se as variações da deformabilidade da chapa de topo com relação às barras passantes, apresentou variações quanto à capacidade resistente ilustradas pela Figura 5.18. Mantendo-se as barras passantes com diâmetro constante, o aumento da espessura da chapa de topo e o aumento da sua resistência ao escoamento ocasionam um pequeno aumento da capacidade resistente da ligação até o limite da capacidade resistente das barras passantes, devido à eliminação do "efeito alavanca", e até o limite da capacidade resistente da viga. Portanto, observa-se ligeiramente a mudança na linha de plastificação na medida em que a espessura da chapa de topo e/ou a sua resistência ao escoamento aumentam, ou seja, na medida em que a deformabilidade da chapa de topo tornase pequena com relação à deformabilidade das barras passantes. Diferentemente da Tipologia 4, independente do diâmetro das barras passantes, há uma certa influência da espessura da chapa de topo, sendo que esta apresentou maior influência sobre a capacidade resistente da ligação do que a sua resistência ao escoamento.

Figura 5.18 - Influência da chapa de topo da Tipologia 5.

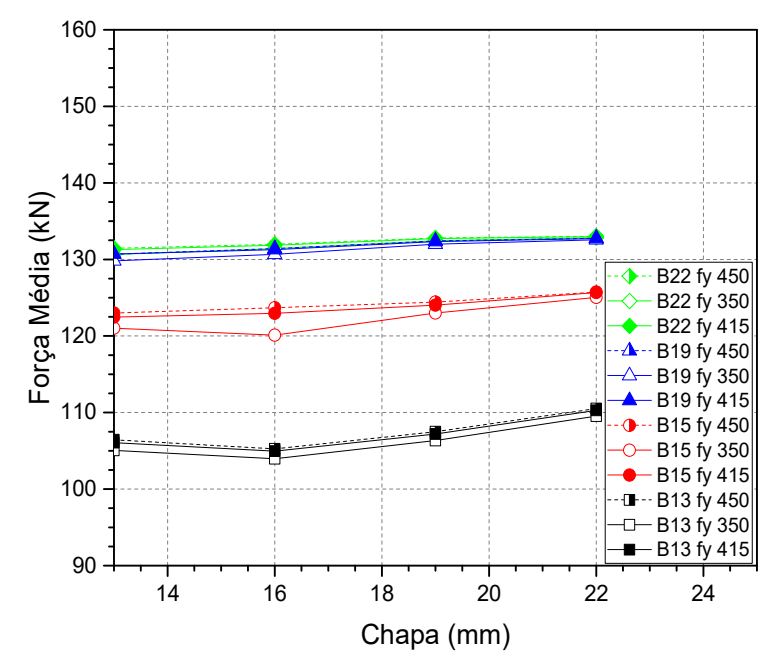

Fonte: Elaborado pela autora.

\section{c) Resistência ao Escoamento do Aço da Viga}

A influência da resistência ao escoamento do aço da viga foi avaliada com três valores de resistência ao escoamento do aço: $365 \mathrm{MPa}$ (valor experimental), $400 \mathrm{MPa}$ e $450 \mathrm{MPa}$. Os resultados obtidos nestas simulações são apresentados na Figura 5.19. Como esperado, nota-se que quanto maior a resistência ao escoamento do aço da viga maior o valor de força máxima 
obtida e percebe-se que a relação entre o valor de resistência ao escoamento do aço da viga e a força máxima atingida é aproximadamente linear. Para os diâmetros das barras na ordem de 19 a $22 \mathrm{~mm}$, foi verificado que um aumento de aproximadamente $25 \%$ na resistência ao escoamento do aço (de fy $=365$ para fy $=450 \mathrm{MPa}$ ) implica em um aumento médio de $20 \%$ na força máxima atingida pelas ligações analisadas. Já para pequenos diâmetros das barras passantes, a influência da resistência ao escoamento do aço da viga não é tão significativa quanto foi para Tipologia 4 devido à perda de rigidez em relação ao eixo de inércia do pilar misto considerado. Assim, conclui-se que o aumento da resistência do aço da viga tem uma importante influência na capacidade resistente da ligação, pois como visto na investigação experimental, atinge-se o momento de plastificação da viga.

Figura 5.19 - Influência da resistência ao escoamento do aço da viga da Tipologia 5.

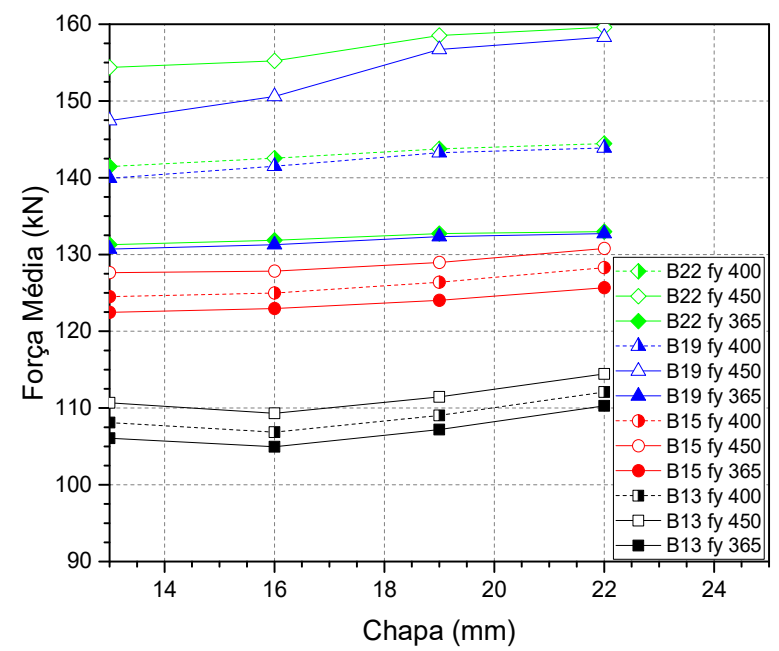

Fonte: Elaborado pela autora.

\section{d) Carregamento do Pilar}

Na Figura 5.20 estão mostrados os resultados da análise paramétrica do carregamento do pilar. Os modelos numéricos com um maior carregamento do pilar apresentaram maior capacidade resistente, mas as diferenças encontradas foram insignificantes na ordem de $1 \%$. Observa-se que a partir do diâmetro de $19 \mathrm{~mm}$ das barras passantes, quase não há variação da capacidade resistente em função do carregamento do pilar. Em divergência à Tipologia 4, foi predominante o alívio do momento fletor atuante na ligação em relação à força cortante e em relação ao eixo de inércia do pilar misto. 
Figura 5.20 - Influência do carregamento do pilar da Tipologia 5.

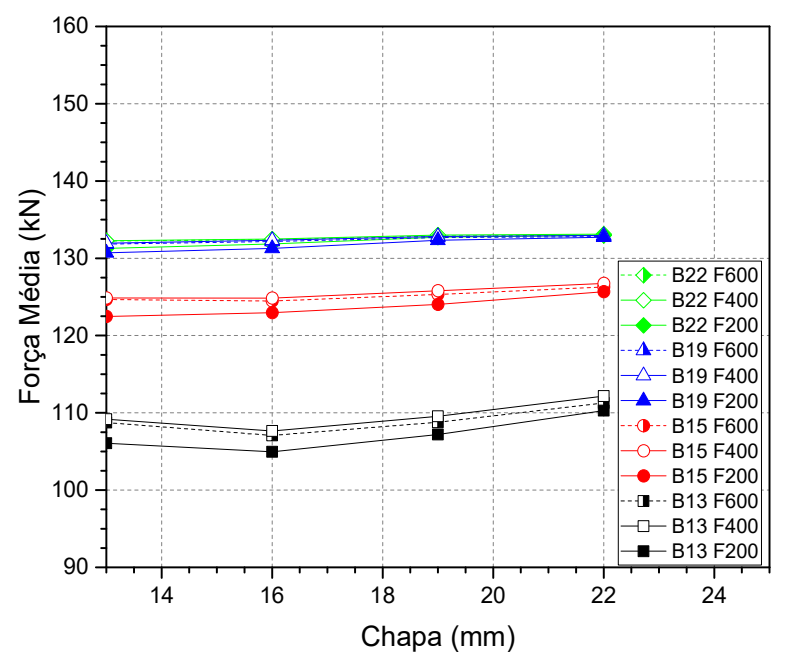

Fonte: Elaborado pela autora.

\subsection{Considerações Finais}

O programa experimental contemplou dois ensaios pilotos para definição da geometria e quatro ensaios definitivos para análise comparativa da contribuição do concreto na ligação e do eixo de inércia do pilar misto parcialmente revestido. A simulação numérica foi realizada para extrapolar os resultados obtidos para as tipologias sem interrupção do concreto na ligação variando o eixo de inércia do pilar, já que são o objeto de estudo deste trabalho. Os resultados do modelo numérico apresentaram coerência e boa representatividade quando confrontados com os resultados experimentais, principalmente nas etapas iniciais de carregamento. No entanto, no regime plástico, os resultados em alguns pontos não foram perfeitamente calibrados devido à malha gerada para chapa de topo e à não modelagem da solda, e posteriormente, a sua eliminação dos modelos numéricos. Além disso, a divergência ocorre por causa de diversos fatores, como simplificações adotadas, imperfeições iniciais, tensões residuais, etc.

Quanto à simulação numérica do contato entre os elementos, utilizando uma interface linear, a escolha foi adequada, pois apresentou facilidade de convergência e a transferência de forças entre os elementos foi satisfatória. Foi possível confirmar, através da análise numérica, a contribuição do concreto de revestimento na ligação. Já a análise paramétrica possibilitou ampliar algumas conclusões. A variação da resistência do aço da viga gerou um aumento de 15 a $20 \%$ da capacidade resistente da ligação, principalmente para grandes diâmetros. Já para pequenos diâmetros, o diâmetro da barra passante apresentou maior influência na força última e a modificação dos outros parâmetros não obteve grande influência no comportamento global. 


\section{CONCLUSÕES}

O objetivo principal deste trabalho foi estudar o comportamento de ligações viga-pilar misto parcialmente revestidos com barras passantes e chapa de topo, visando avaliar a contribuição do concreto de revestimento na ligação e a influência do eixo de inércia do pilar misto. Para isso foi feita uma revisão bibliográfica dos trabalhos e modelos teóricos disponíveis na literatura técnica. Além disso, foi realizada uma investigação experimental envolvendo seis ensaios de ligação viga-pilar misto e uma simulação numérica, a fim de analisar a importância de outros parâmetros envolvidos no comportamento geral da ligação.

Na revisão bibliográfica foi constatada que a maioria dos artigos técnicos sobre ligação viga-pilar misto se resumia a ensaios com modelos submetidos a carregamentos cíclicos e pilares mistos preenchidos. Outra importante característica refere-se aos detalhes de ligação que, em sua maioria, foram desenvolvidos com a interrupção do concreto na ligação, no caso de pilar misto parcialmente revestido, no eixo de maior inércia do pilar misto. Com isso, as tipologias de ligação abordadas neste trabalho foram elaboradas, buscando detalhes simples e de fácil execução.

A seguir são apresentadas as principais conclusões que puderam ser elaboradas das diferentes análises realizadas. A partir da investigação experimental descrita no presente estudo observou-se que:

a) $\mathrm{O}$ comportamento estrutural de ligações entre viga e pilar misto parcialmente revestido depende do eixo de flexão. Quando a flexão ocorre em torno do eixo de menor inércia do pilar misto, há a redução da rigidez inicial na ordem de $180 \%$ e da capacidade resistente da ligação na ordem de 43\%;

b) Na análise da influência da solda entre a chapa de topo e a viga de aço, os resultados obtidos para as tipologias sem interrupção do concreto de revestimento na ligação (Tipologias 4 e 5) apresentam diferenças na capacidade resistente, pois houve ruptura parcial da solda na Tipologia 5;

c) A partir das comparações entre os resultados dos ensaios das tipologias de ligações é possível concluir que a presença do concreto de revestimento na ligação contribui significativamente no aumento da rigidez e da capacidade resistente da ligação. No eixo de maior inércia do pilar, esse acréscimo foi na ordem de $265 \%$ para capacidade resistente e 306\% para rigidez inicial. Já no eixo de menor inércia do pilar, não houve ganho de rigidez inicial, somente de capacidade resistente na ordem de 169\%. 
O concreto comporta-se como um enrijecedor do perfil de aço do pilar e das barras passantes;

d) Verifica-se a mudança da linha de plastificação e da linha neutra com o aumento da espessura da chapa de topo de $16 \mathrm{~mm}$ para 22,2 $\mathrm{mm}$ entre as Tipologias 4 e 5;

e) Em relação à Tipologia 6, a ligação no eixo de menor inércia do pilar misto com a interrupção do concreto de revestimento, houve instabilidade no ensaio por causa da largura da chapa de topo ser igual à largura do pilar misto. Uma solução seria aumentar a largura da chapa de topo e acrescentar uma contraplaca soldada entre as mesas do perfil de aço do pilar misto na região da ligação para enrijecer a ligação;

f) O método das componentes para prever a capacidade resistente da ligação no Anexo A demonstra ser suficiente para as componentes: chapa de topo, viga de aço, barras passantes e solda, sendo necessária uma adequação para verificação do pilar misto. Esse método, recomendado pelo EC3 (2005), subestimou a capacidade resistente para as ligações no eixo de maior inércia do pilar, em torno de 25\% para Tipologia 3 e 10\% para Tipologia 4. Para as tipologias dimensionadas, estimou bem o modo de falha, porém, a Tipologia 5 rompeu antes do esperado, provavelmente por uma falha na execução da solda;

g) Por fim, as ligações propostas nos eixos de maior e menor inércia do pilar sem a interrupção do concreto de revestimento se apresentam mais adequadas para aplicação no pilar misto parcialmente revestido e são classificadas como semirrígidas. O estudo comprova a eficácia da ligação com chapa de topo e barras passantes sem a interrupção do concreto de revestimento para pilares parcialmente revestidos independente do eixo de inércia do pilar.

Para se obter um modelo numérico que represente fielmente o modelo físico, o ideal seria manter suas características as mais próximas possíveis. No entanto, as interfaces entre os elementos da ligação e a aderência perfeita entre a chapa de topo e a viga de aço nos modelos numéricos foram um artifício encontrado para reproduzir o comportamento da ligação. Foram construídos modelos numéricos tridimensionais com elementos finitos sólidos, considerando relações constitutivas não lineares para os materiais utilizados. Já para as interfaces foi adotado um modelo linear. As simulações numéricas são compostas por duas etapas: a calibração dos modelos numéricos por meio da comparação com os resultados experimentais das tipologias sem interrupção do concreto na ligação e o desenvolvimento de um estudo paramétrico para 
extrapolar os resultados experimentais. Com relação à validação dos modelos numéricos podese destacar:

a) Os modelos numéricos preveem satisfatoriamente os valores de capacidade resistente e rigidez inicial para os modelos com interface entre a chapa de topo e a viga. Porém, foi assumido a aderência perfeita entre chapa de topo e a viga, pois a exclusão da solda não interferia na análise comparativa dos outros parâmetros;

b) Há uma boa correlação entre as curvas Força Média vs. Deformações dos elementos estruturais obtidas numericamente e experimentalmente. As deformações nas mesas do perfil da viga, nas barras passantes e no concreto de revestimento são representadas satisfatoriamente pelo modelo numérico no trecho linear. Já a estimativa dos valores de deformações na chapa de topo é satisfatória somente para a Tipologia 4, indicando que para Tipologia 5 houve divergência em razão da malha gerada para chapa de topo.

Por se tratar de um ensaio difícil de ser executado e oneroso, poucos parâmetros da ligação puderam ser analisados experimentalmente. Então, foi desenvolvida uma análise paramétrica a partir de simulações numéricas, analisando ao todo 272 modelos de ligação com a variação de parâmetros, tais como o diâmetro dos parafusos, a espessura da chapa de topo, o carregamento do pilar e a resistência ao escoamento do aço dos elementos estruturais. Os resultados obtidos foram satisfatórios, fornecendo informações importantes sobre o comportamento desse tipo de ligação sem interrupção do concreto de revestimento. Com base nos resultados obtidos pode-se dizer que:

a) $\mathrm{O}$ aumento da resistência ao escoamento do aço da viga tem grande influência na capacidade resistente da ligação, principalmente nos modelos de ligação no eixo de maior inércia do pilar misto e para grandes diâmetros das barras passantes (19 e 22 $\mathrm{mm}$ ). Há um ganho de $20 \%$ na capacidade resistente nesses casos, indicando a importância desse parâmetro para análises futuras. A variação do valor da força máxima em função da resistência ao escoamento do aço da viga é aproximadamente linear;

b) A influência do diâmetro das barras passantes e de sua resistência ao escoamento independe do tipo de tipologia analisada, ou seja, tem influência semelhante em modelos de ligação nos eixos de maior e menor momento de inércia do pilar misto. Com o aumento do diâmetro dos parafusos de $13 \mathrm{~mm}$ para $19 \mathrm{~mm}$, há um aumento 
da capacidade resistente na ordem de 15\%, mas existe um limite, a partir do diâmetro de 19 mm, que esse parâmetro deixa de influenciar na capacidade resistente;

c) A variação da espessura da chapa de topo e da sua resistência ao escoamento também proporciona pequenas alterações no comportamento da ligação. Quando foram utilizados os diâmetros das barras passantes entre 13 a $16 \mathrm{~mm}$, ocorreu um incremento na capacidade resistente em torno de 5\% na alteração das espessuras das chapas de topo de 13 a $22 \mathrm{~mm}$. Para diâmetros superiores a esses, a chapa de topo tem ligeira influência na capacidade resistente somente em relação aos modelos de ligação no eixo de menor inércia do pilar misto;

d) Com base nos resultados da análise paramétrica do carregamento do pilar não é possível retirar informações importantes a respeito da influência desse parâmetro no comportamento da ligação. A capacidade resistente da viga de aço é o elemento determinante da capacidade resistente da ligação, sendo necessária uma alteração da seção da viga para uma análise mais profunda dos outros parâmetros.

Com base em todas as análises efetuadas e no comportamento apresentado pelas ligações viga-pilar misto parcialmente revestido, pode-se concluir que as mesmas são adequadas para utilização em edifícios de múltiplos pavimentos e é de grande interesse a não interrupção do concreto de revestimento. Além disso, a ligação proposta é de fácil execução e detalhe simples, sendo possível a desmontagem da estrutura após o endurecimento do concreto. Para pilares mistos de canto e laterais, é possível prever um dispositivo de ancoragem da barra passante na região onde não tem continuidade da estrutura.

\subsection{Sugestões para Trabalhos Futuros}

Como este trabalho tinha caráter exploratório, alguns questionamentos surgiram em função dos resultados obtidos. Para dar continuidade às pesquisas sobre ligação entre viga e pilar misto parcialmente revestido com concreto, são sugeridos:

- Aplicação de carregamento cíclico com ou sem aplicação de força horizontal na cabeça do pilar. Carregamentos desbalanceados em modelos cruciformes e ensaio com pilares de canto;

- A avaliação da influência da laje por meio da experimentação física e numérica no comportamento das tipologias sem interrupção do concreto do pilar na ligação; 
- Para validar os resultados das análises paramétricas realizadas, seria interessante o ensaio de modelos físicos com as mesmas características utilizadas. Como a capacidade resistente da viga teve grande influência no comportamento da ligação, é necessário um estudo mais aprofundado desse parâmetro com variação da resistência ao escoamento e de seções, considerando uma solda com maior espessura;

- Desenvolvimento de equações para determinação das forças nas linhas de barras de ligações com chapa de topo sem a interrupção do concreto e no eixo de menor momento de inércia do pilar misto;

- Análise da influência do comportamento de ligações mistas no comportamento de pórticos e de ligações mistas sob altas temperaturas (incêndio);

- Realização de simulações numéricas com a incorporação de elementos de contato.

Acredita-se que a continuidade das pesquisas relativas às ligações entre vigas e pilares parcialmente revestidos contribuirá para o avanço e a difusão das estruturas mistas, proporcionando desenvolvimento tecnológico do setor construtivo e a execução de estruturas com alto desempenho. 


\section{REFERÊNCIAS BIBLIOGRÁFICAS}

ARCELORMITTAL. Telha Forma Colaborante Steel Deck Polydeck 59S. Disponível em: http://www.perfilor.com.br/lermais_materias.php?cd_materias=142. Acesso em: 01 jul. 2020.

ASSOCIAÇÃO BRASILEIRA DE NORMAS TÉCNICAS. NBR 7222: Argamassa e concreto - determinação à tração por compressão diametral de corpos-de-prova cilíndricos. Rio de Janeiro, 2011.

ASSOCIAÇÃO BRASILEIRA DE NORMAS TÉCNICAS. NBR 5739: Concreto: ensaio de compressão de corpos-de-prova cilíndricos. Rio de Janeiro, 2018.

ASSOCIAÇÃO BRASILEIRA DE NORMAS TÉCNICAS. NBR ISO 6892-1: Materiais metálicos - Ensaio de tração Parte 1: Método de ensaio à temperatura ambiente. Rio de Janeiro, 2013.

ASSOCIAÇÃO BRASILEIRA DE NORMAS TÉCNICAS. NBR 8800: Projeto de estruturas de aço e de estruturas mistas de aço e concreto de edifícios. Rio de Janeiro, 2008.

ASSOCIAÇÃO BRASILEIRA DE NORMAS TÉCNICAS. NBR 6118: Projeto de estruturas de concreto - Procedimento. Rio de Janeiro, 2014.

ASTM A370: Standard Test Methods and Definitions for Mechanical Testing of Steel Products, ASTM International, West Conshohocken, PA, 2017.

ATAEI, A; BRADFORD, M. A; LIU, X. Computational modelling of the moment-rotation relationship for deconstructable flush end plate beam-to-column composite joints. Journal of Constructional Steel Research, v. 129, p. 75-92, 2017.

ATAEI, A; BRADFORD, M. A; LIU, X. Experimental study of flush end plate beam-to-column composite joints with precast slabs and deconstructable bolted shear connectors. Structures, v. 7, p. 43-58, 2016.

BASTOS, P. S. S. Análise experimental de dormentes de concreto protendido reforçados com fibras de aço. Tese (Doutorado) - Escola de Engenharia de São Carlos, Universidade de São Paulo, São Carlos, 1999, 256 p.

BURSI, O. S; SUN, F; POSTAL, S. Non-linear analysis of steel-concrete composite frames with full and partial shear connection subjected to seismic loads. Journal of Constructional Steel Research, v. 61, p. 67-92, 2005.

CAVAlCANTE, G. H. F; SILVA, J. D. G. L; SANTOS, L. B. Dimensionamento automatizado de ligações viga-pilar. ConstruMetal, 2014. 
CHICOINE, T; TREMBLAY, R; MASSICOTTE, B; RICLES, J. M; LU, L. Behavior and Strength of partially encased composite columns with built-up shapes. Journal of Structural Engineering, v.128, n. 3, p. 279-288, 2002.

CHOU, C; UANG, C. Cyclic performance of a type of steel beam to steel-encased reinforced concrete column moment connection. Journal of Constructional Steel Research, v. 58, p. 637-663, 2002.

\section{COMITÉ EURO-INTERNATIONAL DU BÉTON. CEB MODEL CODE 1990, 1990.}

DE NARDIN, S; EL DEBS, A. L. H. C. Composite connections in slim-floor system: An experimental study. Journal of Constructional Steel Research, v. 68, p. 78-88, 2012. Texto completo em: DE NARDIN, S; EL DEBS, A. L. H. C. Investigação de dispositivos de ligação entre pilares preenchidos e vigas mistas em pavimentos mistos delgados. Relatório (Pós-doutorado) - Escola de Engenharia de São Carlos, Universidade de São Paulo, São Carlos, 2007, 153 p.

DE NARDIN, S. Contribuição à utilização de pilares preenchidos: estudo da flexocompreensão de ligações viga-pilar. Tese (Doutorado) - Escola de Engenharia de São Carlos, Universidade de São Paulo, São Carlos, 2003, 341 p.

DHANALAKSHMI, M; BYFIELD, M. P; COUCHMAN, G. H. Composite connections at perimeter locations in unpropped composite floors. Advances in Steel Structures. Chan, Teng and Chung (Eds.), v. 1, p. 8, 2002.

EUROPEAN COMMITTEE FOR STANDARDIZATION. EN 1994-1-1: Eurocode 4 Design of composite steel and concrete structures; Part 1.1: General rules and rules for buildings. Bruxelles, 2004.

EUROPEAN COMMITTEE FOR STANDARDIZATION. EN 1993-1-1: Eurocode 3 Design of steel structures; Part 1.1: General rules and rules for buildings. Londres, 2005.

EUROPEAN COMMITTEE FOR STANDARDIZATION. EN 1993-1-1: Eurocode 3 Design of steel structures; Part 1.8: Design of joints. Brussels, 2005.

FARIAS, R. S. Experimental and theorical analysis of slab effect on the force transfer strength of steel beam to concrete filled columns connection. Dissertação (Mestrado) Escola de Engenharia de São Carlos, Universidade de São Paulo, São Carlos, 2008, 203 p.

FEENSTRA, P. H; BORST, R. DE. Aspects of robust computational modeling for plain and reinforced concrete. HERON, v.38, n.4, p.76, 1993.

FIGUEIREDO, L. M. B. Ligações mistas viga-pilar - Análise teórica e experimental. Tese (Doutorado) - Escola de Engenharia de São Carlos, Universidade de São Paulo, São Carlos, 2004, 206 p.

FU, F; LAM, D. Experimental study on semi-rigid composite joints with steel beams and precast hollowcore slabs. Journal of Constructional Steel Research, v. 62, p. 771-782, 2006. 
HUANG, S; DAVISON, B; BURGESS, I. W. High-temperature tests on joints to steel and partially-encased H-section columns. Journal of Constructional Steel Research, v. 80, p. 243-251, 2013.

HUNAITI, Y. M. Aging effect on bond strength in composite columns. Journal of Materials in Civil Engeneering, v. 6, n. 4, p. 469-473, 1994.

KATAOKA, M. N. Estudo do comportamento de ligações viga-pilar preenchido submetido a ações cíclicas. Tese (Doutorado) - Escola de Engenharia de São Carlos, Universidade de São Paulo, São Carlos, 2011, 192 p.

LIEW, J. Y. R; TEO, T. H; SHANMUGAM, N. E. Composite joints subject to reversal of loading-Part 1: experimental study. Journal of Constructional Steel Research, v. 60, p. 221-246, 2004.

LU, L; XU, Y; ZHENG, H. Investigation of composite action on seismic performance of weakaxis column bending connections. Journal of Constructional Steel Research, v. 129, p. 286$300,2017$.

MATOS, W. S. Steel deck - tecnologia de lajes mistas que dispensa escoramento. 2015. Disponível em: https://engenhariaeetc.wordpress.com/2015/06/14/steel-deck-tecnologia-delajes-mistas-que-dispensa-escoramento/. Acesso em: 01 jul. 2020.

MEHTA, P. K; MONTEIRO, P. J. M. Concreto: Microestrutura, Propriedades e Materiais. Ibracon, v. 1, p. 674, 2008.

MUISE, J. Behaviour of Simple Framing Connections to Partially Concrete Encased H Section Columns. Dissertação (Mestrado) - Dept. of Civil Engineering, University of Toronto, Toronto, Canada, 2000, 114 p.

OLIVEIRA, C. R. Estudo do comportamento de uma ligação viga-pilar. Dissertação (Mestrado) - Escola Superior de Tecnologia e Gestão, Instituto Politécnico de Viseu, Viseu, Portugal, 2011, 113 p.

PEREIRA, M. F. Comportamento estrutural de pilares mistos parcialmente revestidos submetidos à flexo-compressão. Tese (Doutorado) - Escola de Engenharia de São Carlos, Universidade de São Paulo, São Carlos, 2017, 239 p.

PRICKETT, B.S; DRIVER, R.G. Behavior of partially encased columns made with high performance concrete. Structural Engineering Report n. 262, Dept. of Civil and Enviroment Engineering, University of Alberta, Canada, 2006.

QUEIROZ, G. Elementos das estruturas de aço. Imprensa universitária editora, Belo Horizonte, Minas Gerais, 1993.

ROCHA, F.M. Pilares de aço e mistos de aço e concreto inseridos em paredes em situação de incêndio. Tese (Doutorado) - Escola de Engenharia de São Carlos, Universidade de São Paulo, São Carlos, Brasil. Universidade de Coimbra, Portugal, 2016, 262 p. 
ROMANO, V. P. Dimensionamento de ligações viga-coluna com chapa de topo: modelo do Eurocode 3. Dissertação (Mestrado) - Escola de Minas, Universidade Federal de Ouro Preto, Ouro Preto, 2001, 299 p.

SALVATORE, W; BURSI, O. S; LUCCHESI, D. Design, testing and analysis of high ductile partial-strength steel-concrete composite beam-to-column joints. Computers and Structures, v. 83, p. $2334-2352,2005$.

TINEO, R. P; DE NARDIN, S. Influência de parâmetros geométricos no comportamento da ligação mista viga-pilar preenchido com chapa passante. Revista Eletrônica de Engenharia Civil, v. 13, p. 76-94, 2017.

TREMBLAY, R; MASSICOTTE, B; FILION, I; MARANDA, R. Experimental study on the behavior of partially encased composite columns made with light welded $\mathrm{H}$ steel shapes under compressive axial loads. Proceedings - Annual Technical Session, Structural Stability Research Council, Atlanta, p. 195-204, 1998.

TRISTÃO, G. A. Análise teórica e experimental de ligações viga mista-pilar de extremidade com cantoneiras de assento e alma. Tese (Doutorado) - Escola de Engenharia de São Carlos, Universidade de São Paulo, São Carlos, 2006, 282p.

VIEITO, A. A. S. Análise e dimensionamento de ligações viga-pilar com placa de extremidade. Dissertação (Mestrado) - Escola Superior de Tecnologia e Gestão, Instituto Politécnico de Viana do Castelo, Viana do Castelo, Portugal, 2015, 119 p.

WANG, K; YUAN, S; CHEN, Z; ZHI, H; SHI, G; CAO, D. Experimental study on hysteretic behavior of composite frames with concrete-encased CFST columns. Journal of Constructional Steel Research, v. 123, p. 110-120, 2016.

YANG, B; TAN, K. H; XIONG, G; NIE, S. D. Experimental study about composite frames under an internal column-removal scenario. Journal of Constructional Steel Research, v. 121, p. 341-351, 2016.

ZENG, L; CUI, Z; XIAO, Y; JIN, S; WU, Y. Cyclical behavior of concrete-encased composite frame joints with high strength concrete. Advances in Materials Science and Engineering, $p$. $13,2015$.

ZHAO, G; FENG, C; WANG, L. Hysteretic behavior on connection node between partially encased concrete column and steel beam. Applied Mechanics and Materials Online. Trans Tech Publications, v. 353-356, p. 2065-2068, 2013.

ZOETEMEIJER, P. A design method for the tension side of statically loaded, bolted beam-tocolumn connections. HERON, v. 20, 1974. 


\section{ANEXO A}

\section{A.1) Tipologia 3}

De acordo com o EC3 Parte 1.8 (2005), a força resultante na parte comprimida deve ser considerada atuando na linha média da mesa comprimida e a força resultante na parte tracionada atuando na linha média dos parafusos em tração. Para três ou mais linhas de parafusos na região tracionada, o braço de alavanca é determinado considerando efetivas apenas as duas linhas de parafusos mais afastadas. Uma vez definidas as características do modelo físico, foi feita a análise teórica do mesmo, utilizando-se as expressões teóricas mostradas no Capítulo 3 do EC3 (2005), a fim de se obter uma previsão teórica da capacidade resistente da ligação. A seguir, é apresentada uma previsão teórica da Tipologia 3 com a ligação no eixo de maior momento de inércia do pilar misto e com a interrupção do concreto na ligação.

\section{a) Descrição dos Elementos de Ligação}

O pilar tem $87,10 \mathrm{~cm}$ de comprimento desde a ligação estudada até ao solo e estende-se até $91,25 \mathrm{~cm}$ para cima da ligação considerada. A viga tem 1,5 $\mathrm{m}$ de comprimento e o perfil possui as características indicadas na Figura 4.1b. A chapa de extremidade tem 334 x 152 x 16 mm dimensões e os parafusos têm diâmetro de $16 \mathrm{~mm}$, encontrando-se as suas propriedades na Tabela 4.3. Visto que as forças de compressão atuantes em ambos os perfis são muito reduzidas, admitiu-se que para o efeito de classificação dos perfis encontram-se ambos em flexão simples. Assim considera-se que tanto a viga como o pilar são de classe 1 , ou seja, admite-se uma distribuição de tensões em regime plástico.

Onde:

- Altura do perfil (h);

- Largura do perfil (b);

- Espessura da alma do perfil $\left(\mathrm{t}_{\mathrm{w}}\right)$;

- Espessura da mesa do perfil $\left(\mathrm{t}_{\mathrm{f}}\right)$;

- Raio de concordância do perfil (r);

- Área da secção transversal do perfil (A);

- Momento de Inercia do perfil (I);

- Módulo elástico do perfil (W);

- Módulo plástico do perfil (Z); 
- Tensão de escoamento do perfil $\left(f_{\mathrm{y}}\right)$;

- Tensão ruptura do perfil $\left(f_{u}\right)$.

Em que:

- Diâmetro do parafuso (d);

- Diâmetro do furo $\left(\mathrm{d}_{0}\right)$;

- Área bruta da seção transversal do parafuso (A);

- Área da zona roscada do parafuso $\left(\mathrm{A}_{\mathrm{s}}\right)$;

- Largura da porca e cabeça do parafuso $\left(\mathrm{d}_{\mathrm{m}}\right)$;

- Espessura da porca $\left(\mathrm{e}_{\mathrm{p}}\right)$;

- Espessura da cabeça do parafuso (k);

- Espessura da anilha $\left(\mathrm{s}_{1}\right)$;

- Tensão de escoamento dos parafusos $\left(f_{y b}\right)$;

- Tensão de ruptura dos parafusos $\left(f_{u b}\right)$;

\section{b) Identificação das Componentes}

Tendo o momento atuante na ligação sentido negativo, é natural que as componentes localizadas junto à mesa inferior da viga se encontrem em compressão e as restantes à tração. Assim, são identificadas as seguintes componentes que influenciam o valor do momento resistente da ligação na Tabela A.1.

Tabela A.1 - Identificação das componentes ativas em cada linha de compressão ou tração.

\begin{tabular}{|c|c|}
\hline \multicolumn{2}{|c|}{ Componentes } \\
\hline 1 & Alma do pilar ao cisalhamento \\
\hline 2 & Alma do pilar em compressão transversal \\
\hline 3 & Alma do pilar em tração transversal \\
\hline 4 & Mesa do pilar em flexão transversal \\
\hline 5 & Chapa de extremidade à flexão \\
\hline 7 & Mesa e alma da viga em compressão \\
\hline 8 & Alma da viga em tração \\
\hline 10 & Parafusos à tração \\
\hline 19 & Soldas à tração \\
\hline Linha & Componentes Ativas \\
\hline 1 & $3,4,10$ e 19 \\
\hline 2 & $3,4,8,10$ e 19 \\
\hline Compressão & 1,2 e 7 \\
\hline
\end{tabular}

Fonte: Elaborado pela autora. 
c) Considerações Iniciais de Dimensionamento

Para calcular o momento resistente da ligação e a sua rigidez rotacional, consideraramse as seguintes hipóteses:

- O centro de compressão encontra-se a meio da espessura da mesa inferior da viga;

- O centro de tração é considerado inicialmente como localizado a meio da espessura da mesa superior da viga. Após o cálculo da rigidez de todas as componentes, é estimada a sua localização mais exata.

d) Cálculo do Valor Resistente das Componentes - Linha de Compressão

Componente 1 - Alma do pilar sujeita ao cisalhamento:

- Verificação da condição de limite da esbelteza da alma do pilar:

$$
\begin{gathered}
\varepsilon=\sqrt{\frac{235}{380}}=0,79 \\
\frac{d_{c}}{t_{w c}}=\frac{119}{5,8}=20,51 \\
20,51 \leq 69 \cdot 0,79=54,51(\mathrm{ok})
\end{gathered}
$$

- Verificada esta condição, considera-se aplicável o método já descrito. O cálculo da área resistente ao cisalhamento do pilar:

$A_{v c}=29-2 \cdot 15,2 \cdot 0,66+(0,58+2 \cdot 1) \cdot 0,66=10,64 \mathrm{~cm}^{2}$

- Resistência da alma do pilar ao cisalhamento:

$$
\begin{gathered}
V_{w p, R}=\frac{0,9 \cdot 380 \cdot 10,64 \cdot 10^{-1}}{\sqrt{3}}=210,09 \mathrm{kN} \\
k_{1}=\infty(\beta=0)
\end{gathered}
$$

Componente 2 - Alma do pilar sujeita à compressão:

- Levando em conta que o presente estudo é de ligação aparafusada com chapa de topo, o comprimento efetivo da alma do pilar em compressão transversal é calculado através da seguinte expressão:

$$
b_{e f f, c, w c}=9,1+2 \sqrt{2} \cdot 6+5 \cdot(6,6+10)+16=125,07 \mathrm{~mm}
$$


- É necessário verificar qual o valor de $\mathrm{s}_{\mathrm{p}}$ a ser utilizado. Este valor depende da relação entre a espessura da chapa de topo, $\mathrm{t}_{\mathrm{p}}$, e a extensão desta para além da mesa inferior da viga que é igual a $11 \mathrm{~mm}$.

$$
t_{p}=16 \geq 11 \mathrm{~mm} \text {, então } s_{p}=t_{p}=16 \mathrm{~mm}
$$

- Observando a Tabela 3.3 conclui-se que:

$$
\beta=0 \rightarrow \omega=1
$$

- Cálculo do coeficiente de redução, $\rho$ :

$$
\begin{gathered}
\bar{\lambda}_{p}=0,932 \sqrt{\frac{125,07 \cdot 119 \cdot 380}{200000 \cdot 5,8^{2}}}=0,855 \\
\bar{\lambda}_{p}>0,72 \rightarrow \rho=\frac{\bar{\lambda}_{p}-0,2}{\bar{\lambda}_{p}{ }^{2}}=\frac{0,855-0,2}{0,855^{2}}=0,896 \\
k_{w c}=1
\end{gathered}
$$

- Cálculo da resistência da alma do pilar à compressão transversal:

$$
\begin{gathered}
F_{c, w c, R}=1 \cdot 1 \cdot 0,896 \cdot 125,07 \cdot 5,8 \cdot 380 \cdot 10^{-3}=246,99 \mathrm{kN} \\
k_{2}=\frac{0,7 \cdot 125,07 \cdot 5,8}{119}=4,27
\end{gathered}
$$

Componente 7 - Mesa e alma da viga em compressão:

$$
\begin{gathered}
M_{R}=429 \cdot 380 \cdot 10^{-3}=163,02 \mathrm{kN} \\
F_{c, f b, R}=\frac{163,02}{(258-9,1) \cdot 10^{-3}}=654,96 \mathrm{kN} \\
k_{7}=\infty
\end{gathered}
$$

e) $1^{a}$ Linha de Parafusos Tracionados

- Como se trata de uma linha de extremidade, a sua resistência é considerada como a resistência da linha de parafusos atuando isoladamente. 
Componente 4 - Mesa do pilar à flexão transversal:

- Definição dos parâmetros geométricos:

$$
\begin{gathered}
m=\frac{b_{p}-t_{w c}}{2}-0,8 r_{c}=\frac{90-5,8}{2}-0,8 \cdot 10=34,1 \mathrm{~mm} \\
e_{\text {mín }}=31 \mathrm{~mm} \\
n \leq e_{\text {mín }} \text { e } 1,25 m \rightarrow n=31 \mathrm{~mm} \\
e_{1}=912,5-75=837,5 \mathrm{~mm}
\end{gathered}
$$

- Já que a $1^{\text {a }}$ linha de parafusos à tração é uma linha de extremidade adotam-se as seguintes expressões para o comprimento efetivo dos modos de ruptura 1 e 2 da

\begin{tabular}{|c|c|c|}
\hline \multicolumn{3}{|c|}{ Linha de parafusos isolada } \\
\hline & Configuração Circular & Configuração não Circular \\
\hline $\begin{array}{l}\text { Linha de parafusos de } \\
\text { extremidade }\end{array}$ & $\begin{array}{c}\text { Menor valor: } \\
2 \pi m=2 \pi \cdot 34,1=214,26 \\
\pi m+2 e_{1}=\pi \cdot 34,1+2 . \\
837,5=1782,13\end{array}$ & 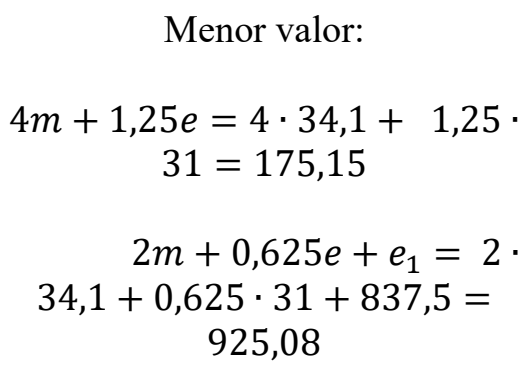 \\
\hline Modo 1 & \multicolumn{2}{|c|}{$l_{e f f, 1}=175,15 \leq 214,26$} \\
\hline Modo 2 & \multicolumn{2}{|c|}{$l_{e f f, 2}=175,15$} \\
\hline
\end{tabular}
mesa do pilar (Tabela A.2):

Tabela A.2 - Comprimento efetivo da mesa do pilar à flexão para a $1^{\text {a }}$ linha de parafusos isolada (ligação não reforçada).

Fonte: Elaborado pela autora.

Assim, $1_{\text {eff }, 1}=175,15 \mathrm{~mm}$ e $l_{\text {eff }, 2}=175,15 \mathrm{~mm}$.

Observação: Esta linha de parafusos só deverá ser analisada como parte de um grupo de parafusos quando forem analisados os eixos de tração inferiores.

- Resistência individual de cada parafuso à tração:

$$
\begin{gathered}
F_{t, R}=0,9 \cdot 850 \cdot 201,06 \cdot 10^{-3}=153,81 \mathrm{kN} \\
k_{10}=\frac{1,6 \cdot 201,06}{16+6,6+\frac{10}{2}+\frac{15}{2}+8}=7,46 \mathrm{~mm}
\end{gathered}
$$


- Resistência à punção da mesa do pilar:

$$
B_{p, R}=0,6 \pi \cdot 25 \cdot 6,6 \cdot 500 \cdot 10^{-3}=155,51 \mathrm{kN}>F_{t, R} \text { ok }
$$

- Verificação da existência de forças de alavanca:

$$
\begin{gathered}
l_{b}=16+6,6+\frac{10}{2}+\frac{15}{2}+8=43,1 \mathrm{~mm} \\
l_{b}^{*}=\frac{8,8 m^{3} A_{s} n_{b}}{\sum l_{e f f, 1} t_{f}^{3}}=\frac{8,8 \cdot 34,1^{3} \cdot 201,06 \cdot 1}{175,15 \cdot 6,6^{3}}=1393,25 \mathrm{~mm}
\end{gathered}
$$

Como $\mathrm{l}_{\mathrm{b}}<\mathrm{l}_{\mathrm{b}}{ }^{*}$, verifica-se a existência de forças de alavanca.

- Cálculo da resistência da mesa do pilar à flexão transversal:

$$
\begin{gathered}
M_{p l, 1, R}=M_{p l, 2, R}=0,25 \cdot 175,15 \cdot 6,6^{2} \cdot 380 \cdot 10^{-6}=0,725 \mathrm{kN} . \mathrm{m} \\
F_{t, 1, R}=\frac{4 M_{p l, 1, R}}{m}=\frac{4 \cdot 0,725}{34,1 \cdot 10^{-3}}=85 \mathrm{kN} \\
F_{t, 2, R}=\frac{2 M_{p l, 2, R}+n \sum F_{t, R}}{m+n}=\frac{2 \cdot 0,725+31 \cdot 2 \cdot 153,81 \cdot 10^{-3}}{(34,1+31) \cdot 10^{-3}}=168,76 \mathrm{kN} \\
F_{t, 3, R}=\sum F_{t, R}=2 \cdot 153,81=307,62 \mathrm{kN}
\end{gathered}
$$

Verifica-se que o modo de ruptura para a mesa do pilar à flexão na $1^{\mathrm{a}}$ linha de parafusos é o primeiro. Logo a resistência da mesa à flexão transversal é: $85 \mathrm{kN}$.

Componente 3 - Alma do pilar sob tração transversal:

- Como se trata de uma ligação com chapa de extremidade, a largura efetiva da alma do pilar à tração é igual ao menor comprimento efetivo da mesa do pilar à flexão.

$$
\begin{gathered}
b_{e f f, t, w c}=l_{e f f, 1}=175,15 \mathrm{~mm} \\
\omega=1 \\
F_{t, w c, R}=1 \cdot 175,15 \cdot 5,8 \cdot 380 \cdot 10^{-3}=386,03 \mathrm{kN}
\end{gathered}
$$

Componente 5 - Chapa de extremidade à flexão:

- Definição dos parâmetros geométricos:

$$
\begin{aligned}
e & =31 \mathrm{~mm} \\
w & =90 \mathrm{~mm}
\end{aligned}
$$




$$
\begin{gathered}
e_{x}=31,5 \mathrm{~mm} \\
m_{x}=33,5-0,8 \sqrt{2} \cdot 6=26,71 \mathrm{~mm} \\
b_{p}=152 \mathrm{~mm} \\
m=\frac{90-6,1}{2}-0,8 \sqrt{2} \cdot 6=35,16 \mathrm{~mm}
\end{gathered}
$$

- A $1^{\text {a }}$ linha de parafusos classifica-se como "Linha de parafusos na parte saliente da mesa tracionada da viga". Assim, o comprimento efetivo da chapa de

\begin{tabular}{|c|c|c|}
\hline & Configuração Circular & Configuração não Circular \\
\hline $\begin{array}{c}\text { Extensão da chapa de } \\
\text { topo }\end{array}$ & $\begin{array}{c}\text { Menor valor: } \\
2 \pi m_{x}=2 \pi \cdot 26,71=167,82 \\
\pi m_{x}+w=\pi \cdot 26,71+ \\
90=173,91 \\
\pi m_{x}+2 e=\pi \cdot 26,71+ \\
2 \cdot 31=145,91\end{array}$ & $\begin{array}{c}\text { Menor valor: } \\
4 m_{x}+1,25 e_{x}=4 \cdot 26,71+ \\
1,25 \cdot 31,5=146,22 \\
2 m_{x}+0,625 e_{x}+e= \\
2 \cdot 26,71+0,625 \cdot 31,5+31= \\
104,10 \\
2 m_{x}+0,625 e_{x}+ \\
0,5 w=2 \cdot 26,71+0,625 \\
31,5+45=118,10 \\
0,5 b_{p}=0,5 \cdot 152=76\end{array}$ \\
\hline Modo 1 & \multicolumn{2}{|c|}{$l_{e f f, 1}=76 \leq 145,91$} \\
\hline Modo 2 & \multicolumn{2}{|c|}{$l_{e f f, 2}=76$} \\
\hline
\end{tabular}
extremidade à flexão para a $1^{a}$ linha de parafusos é obtido pela Tabela A.3:

Tabela A.3 - Comprimento efetivo da chapa de topo à flexão para a $1^{\text {a }}$ linha de parafusos isolada (ligação não reforçada).

Fonte: Elaborado pela autora.

- Verificação da existência de forças de alavanca:

$$
\begin{gathered}
l_{b}=16+6,6+\frac{10}{2}+\frac{15}{2}+8=43,1 \mathrm{~mm} \\
l_{b}^{*}=\frac{8,8 m^{3} A_{s} n_{b}}{\sum l_{e f f, 1} t_{f}^{3}}=\frac{8,8 \cdot 26,71^{3} \cdot 201,06 \cdot 1}{76 \cdot 16^{3}}=108,3 \mathrm{~mm}
\end{gathered}
$$

Como $\mathrm{l}_{\mathrm{b}}<\mathrm{l}_{\mathrm{b}}{ }^{*}$, verifica-se a existência de forças de alavanca.

- Cálculo da resistência da chapa de extremidade à flexão transversal:

$$
M_{p l, 1, R}=M_{p l, 2, R}=0,25 \cdot 76 \cdot 16^{2} \cdot 345 \cdot 10^{-6}=1,68 \mathrm{kN} . \mathrm{m}
$$


- Nota-se que na linha de parafusos da extensão da chapa de topo, considera-se que o valor de $\mathrm{m}$ do $\mathrm{T}$-stub equivalente é igual a $\mathrm{m}_{\mathrm{x}}$.

$$
\begin{gathered}
n \leq e_{\text {mín }} \text { e } 1,25 m_{x} \rightarrow n=31 \mathrm{~mm} \\
F_{t, 1, R}=\frac{4 M_{p l, 1, R}}{m_{x}}=\frac{4 \cdot 1,68}{26,71 \cdot 10^{-3}}=251,59 \mathrm{kN} \\
F_{t, 2, R}=\frac{2 M_{p l, 2, R}+n \sum F_{t, R}}{m_{x}+n}=\frac{2 \cdot 1,68+31 \cdot 2 \cdot 153,81 \cdot 10^{-3}}{(26,71+31) \cdot 10^{-3}}=223,47 \mathrm{kN} \\
F_{t, 3, R}=\sum F_{t, R}=2 \cdot 153,81=307,62 \mathrm{kN} \\
k_{5}=\frac{0,9 \cdot 76 \cdot 16^{3}}{26,71^{3}}=14,7
\end{gathered}
$$

O terceiro modo de ruptura da chapa de topo e da mesa do pilar à flexão corresponde à ruptura dos parafusos. Logo, este modo é igual para as duas componentes e para todas as linhas de tração quando consideradas como isoladas. Só será diferente quando forem analisadas as linhas de parafusos atuando em grupos.

- Levando em conta todas as componentes da $1^{\text {a }}$ linha de tração analisadas conclui-se que a resistência desta linha é dada por:

$$
P_{r 1}=\operatorname{mínimo}\{85 ; 386,03 ; 223,47\}=85 \mathrm{kN}
$$

- Neste caso, a componente determinante é a mesa do pilar à flexão transversal.

f) $2^{a}$ Linha de Parafusos Tracionados

- No caso das componentes 3 e 4, esta linha de parafusos tem que ser analisada como isolada ou como parte de um grupo de parafusos. No caso das componentes 5 e 7 considera-se apenas a linha de parafusos isolada, pois a mesa da viga funciona como um divisor de grupos de linhas de tração.

Componente 4: Mesa do pilar sujeito a flexão transversal.

- Para a $2^{\text {a }}$ linha de parafusos isolada, os parâmetros geométricos são iguais aos da $1^{\text {a }}$ linha. E como os comprimentos efetivos são iguais aos da $1^{\text {a }}$ linha de parafusos, a verificação de possibilidade de ocorrência de forças de alavanca e 
os valores da resistência da mesa do pilar à tração para os diferentes modos de ruptura também são iguais:

$$
\begin{gathered}
F_{t, 1, R}=85 \mathrm{kN} \\
F_{t, 2, R}=168,76 \mathrm{kN} \\
F_{t, 3, R}=307,62 \mathrm{kN}
\end{gathered}
$$

Assim, o modo de ruptura condicionante é novamente o primeiro.

- Para a $2^{\mathrm{a}}$ linha de parafusos como parte do grupo 1+2:

$$
p=75 \mathrm{~mm}
$$

- Cálculo do comprimento efetivo da $2^{\mathrm{a}}$ linha de parafusos como parte do grupo $1+2$ :

Apesar de esta ser uma linha de parafusos interior quando se analisa a junta de uma forma global, considerando o grupo de linhas de tração $1+2$, a linha passa a ser vista como a linha de extremidade inferior. Por isso, neste caso o seu comprimento efetivo é dado pelas

\begin{tabular}{|c|c|c|}
\hline \multicolumn{3}{|c|}{ Linha de parafusos como parte de um grupo } \\
\hline & Configuração Circular & Configuração não Circular \\
\hline & Menor yalor. & Menor valor: \\
\hline $\begin{array}{l}\text { Linha de extremidade } \\
\text { inferior em grupo }\end{array}$ & $\begin{array}{c}\pi m+p=\pi \cdot 34,1+75= \\
182,13\end{array}$ & $\begin{array}{c}2 m+0,625 e+0,5 p=2 \\
34,1+0,625 \cdot 31+37,5= \\
125,08\end{array}$ \\
\hline & $\begin{array}{l}2 e_{1}+p=2 \cdot 837,5+ \\
\quad 75=1750\end{array}$ & $\begin{aligned} e_{1}+0,5 p= & 837,5+37,5= \\
& 875\end{aligned}$ \\
\hline Modo 1 & \multicolumn{2}{|c|}{$\sum l_{e f f, 1}=2 \cdot 125,08 \leq 2 \cdot 182,13$} \\
\hline Modo 2 & \multicolumn{2}{|c|}{$\sum l_{e f f, 2}=2 \cdot 125,08=250,16$} \\
\hline
\end{tabular}
expressões da Tabela A.4.

Tabela A.4 - Comprimento efetivo do banzo do pilar à flexão para a $1^{\mathrm{a}}$ linha de parafusos como parte do grupo 1+2 (ligação não reforçada).

Fonte: Elaborado pela autora.

- Verificação da existência de forças de alavanca:

É necessário considerar que no grupo de parafusos analisado existem duas linhas de tração.

$$
l_{b}^{*}=\frac{8,8 m^{3} A_{s} n_{b}}{\sum l_{e f f, 1} t_{f}^{3}}=\frac{8,8 \cdot 34,1^{3} \cdot 201,06 \cdot 2}{250,16 \cdot 6,6^{3}}=1950,97 \mathrm{~mm} \gg l_{b}
$$


Assim, verifica-se mais uma vez a existência de forças de alavanca.

- Cálculo da resistência da mesa do pilar à flexão para o grupo de linhas de parafusos $(1+2)$ :

Como cada linha de tração é composta por dois parafusos, é necessário ter em conta que existem no total quatro parafusos para os modos de ruptura 2 e 3.

$$
\begin{gathered}
M_{p l, 1, R}=M_{p l, 2, R}=0,25 \cdot 250,16 \cdot 6,6^{2} \cdot 380 \cdot 10^{-6}=1,04 \mathrm{kN} . \mathrm{m} \\
F_{t, 1, R}=\frac{4 M_{p l, 1, R}}{m}=\frac{4 \cdot 1,04}{34,1 \cdot 10^{-3}}=121,99 \mathrm{kN} \\
F_{t, 2, R}=\frac{2 M_{p l, 2, R}+n \sum F_{t, R}}{m+n}=\frac{2 \cdot 1,04+31 \cdot 4 \cdot 153,81 \cdot 10^{-3}}{(34,1+31) \cdot 10^{-3}}=324,92 \mathrm{kN} \\
F_{t, 3, R}=\sum F_{t, R}=4 \cdot 153,81=615,24 \mathrm{kN}
\end{gathered}
$$

Verifica-se, pois, que o modo de ruptura condicionante é o primeiro.

Estes valores correspondem à resistência do grupo de parafusos 1+2. Porém, para obter a resistência da mesa do pilar à flexão na $2^{\mathrm{a}}$ linha de tração como parte deste grupo é ainda necessário subtrair a resistência da $1^{\mathrm{a}}$ linha destes valores.

$$
\begin{gathered}
F_{t, 1, R}=121,99-85=36,99 \mathrm{kN} \\
F_{t, 2, R}=324,92-85=239,92 \mathrm{kN} \\
F_{t, 3, R}=615,24-85=530,24 \mathrm{kN} \\
k_{4}=\frac{0,9 \cdot 125,08 \cdot 6,6^{3}}{34,1^{3}}=0,82
\end{gathered}
$$

Componente 3 - Alma do pilar sob tração transversal:

- $2^{\mathrm{a}}$ linha de parafusos isolada:

Neste caso em particular, os parâmetros de cálculo são todos iguais aos da $1^{\text {a }}$ linha de tração. Logo, a resistência desta componente tem o mesmo valor obtido para a $1^{\mathrm{a}}$ linha:

$$
F_{t, w c, R}=386,03 \mathrm{kN}
$$

- Para $2^{\mathrm{a}}$ linha de parafusos como parte do grupo $1+2$ :

$$
b_{\text {eff }, t, w c}=250,16 \mathrm{~mm}
$$


164 | ANEXO A

- Resistência da alma do pilar à tração para o grupo de parafusos $(1+2)$ :

$$
F_{t, w c, R}=1 \cdot 250,16 \cdot 5,8 \cdot 380 \cdot 10^{-3}=551,35 \mathrm{kN}
$$

- Resistência da alma do pilar à tração para a $2^{\mathrm{a}}$ linha de tração como parte do grupo de parafusos $(1+2)$ :

$$
\begin{gathered}
F_{t, w c, R}=551,35-85=466,35 \mathrm{kN} \\
k_{3}=\frac{0,7 \cdot 125,08 \cdot 5,8}{119}=4,26
\end{gathered}
$$

Componente 5 - Chapa de extremidade à flexão:

A $2^{\text {a }}$ linha de parafusos é adjacente à mesa tracionada da viga. Logo, para determinar o comprimento efetivo, é necessário determinar o coeficiente retirado do ábaco.

$$
\begin{gathered}
m_{2}=33,5-0,8 \sqrt{2} \cdot 6=26,71 \\
\lambda_{1}=\frac{35,16}{35,16+31}=0,53 \\
\lambda_{2}=\frac{26,71}{35,16+31}=0,40 \\
\alpha \cong 6
\end{gathered}
$$

- Assim obtêm-se os valores de comprimentos efetivos na Tabela A.5:

Tabela A.5 - Comprimento efetivo da chapa de extremidade à flexão para a $2^{\mathrm{a}}$ linha de parafusos isolada (ligação não reforçada).

\begin{tabular}{|c|c|c|}
\hline & Configuração Circular & Configuração não Circular \\
\hline Linha isolada & $2 \pi m=2 \pi \cdot 35,16=220,92$ & $\alpha m=6 \cdot 35,16=210,96$ \\
\hline Modo 1 & $l_{\text {eff,1 }}=210,96 \leq 220,92$ \\
\hline Modo 2 & \multicolumn{2}{|c|}{$l_{\text {eff, }}=210,96$} \\
\hline
\end{tabular}

Fonte: Elaborado pela autora.

- Cálculo da resistência da chapa de extremidade à flexão transversal:

$$
\begin{gathered}
M_{p l, 1, R}=M_{p l, 2, R}=0,25 \cdot 210,96 \cdot 16^{2} \cdot 345 \cdot 10^{-6}=4,66 \mathrm{kN} . \mathrm{m} \\
F_{t, 1, R}=\frac{4 M_{p l, 1, R}}{m}=\frac{4 \cdot 4,66}{35,16 \cdot 10^{-3}}=530,15 \mathrm{kN} \\
F_{t, 2, R}=\frac{2 M_{p l, 2, R}+n \sum F_{t, R}}{m+n}=\frac{2 \cdot 4,66+31 \cdot 2 \cdot 153,81 \cdot 10^{-3}}{(35,16+31) \cdot 10^{-3}}=285 \mathrm{kN}
\end{gathered}
$$




$$
\begin{gathered}
F_{t, 3, R}=\sum F_{t, R}=2 \cdot 153,81=307,62 \mathrm{kN} \\
k_{5}=\frac{0,9 \cdot 210,96 \cdot 16^{3}}{35,16^{3}}=17,9
\end{gathered}
$$

Conclui-se que o modo de ruptura é o segundo.

Componente 8 - Alma da viga em tração:

- De forma análoga à alma do pilar em tração transversal, a largura efetiva desta componente é igual ao comprimento efetivo do $1^{\circ}$ modo de ruptura da chapa de topo à flexão.

$$
b_{e f f, t, w b}=l_{e f f, 1}=210,96
$$

- Assim a resistência desta componente é dada por:

$$
F_{t, w b, R}=210,96 \cdot 6,1 \cdot 380 \cdot 10^{-3}=489 \mathrm{kN}
$$

- Resistência da $2^{\mathrm{a}}$ linha de tração:

$$
P_{r 2}=\operatorname{mínimo}\{85 ; 36,99 ; 386,03 ; 466,35 ; 285 ; 489\} \cong 37 \mathrm{kN}
$$

A resistência da $2^{\mathrm{a}}$ linha de parafusos é dada pela resistência da mesa do pilar à flexão como parte do grupo $(1+2)$.

\section{g) Cálculo do Momento Resistente da Ligação}

- O cálculo do momento resistente da ligação é feito de acordo:

$$
M_{j, R}=\sum_{r} h_{r} F_{t r, R}
$$

- Em que a força de tração de cada linha de parafusos, $F_{\text {tr }}$, equivale à sua componente menos resistente, $\mathrm{P}_{\mathrm{rn}}$, e o braço, $\mathrm{h}_{\mathrm{r}}$, equivale à distância entre $\mathrm{o}$ centro geométrico dos parafusos e o centro de compressão.

- Entretanto, é necessário relembrar que para se verificar o equilíbrio de forças, o somatório das forças de tração não pode ultrapassar a força de compressão máxima, que neste caso é equivalente à resistência da alma do pilar ao cisalhamento. 


$$
\sum_{r} F_{t r}=F_{c r}=V_{w p, R}=210,09 \mathrm{kN}
$$

- Assim, verifica-se, linha a linha, se o somatório das forças de tração ultrapassa ou não o valor de resistência da ligação à compressão.

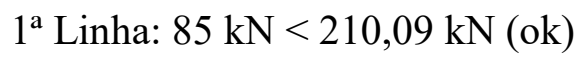

- Nestas condições, a resistência da $1^{a}$ linha de parafusos à tração é aproveitada na sua totalidade.

$$
2^{\mathrm{a}} \text { Linha: } 85+37=122 \mathrm{kN}<210,09 \mathrm{kN}
$$

- Nestas condições, a resistência da $2^{\mathrm{a}}$ linha de parafusos à tração é aproveitada na sua totalidade.

- Finalmente, o momento resistente da ligação é dado por:

$$
M_{j, R}=h_{1} F_{t 1, R}+h_{2} F_{t 2, R}=(286,95 \cdot 85+211,95 \cdot 37) \cdot 10^{-3}=32,23 \mathrm{kN} . \mathrm{m}
$$

\section{h) Momento Resistente da Solda}

Adotando um método simplificado, admite-se que a solda que resiste às forças de tração provocadas por um momento atuante negativo são as soldas que ligam a mesa superior e a alma da viga à chapa de topo. Assim, para este caso, considera-se que os cordões de solda resistentes às forças de tração estão divididos em três grupos, cada um caracterizado por um centro de tração diferente e consequentemente um braço do binário diferente até ao centro de compressão da ligação (Figura A.1).

Figura A.1 - Solda sujeita à tração.

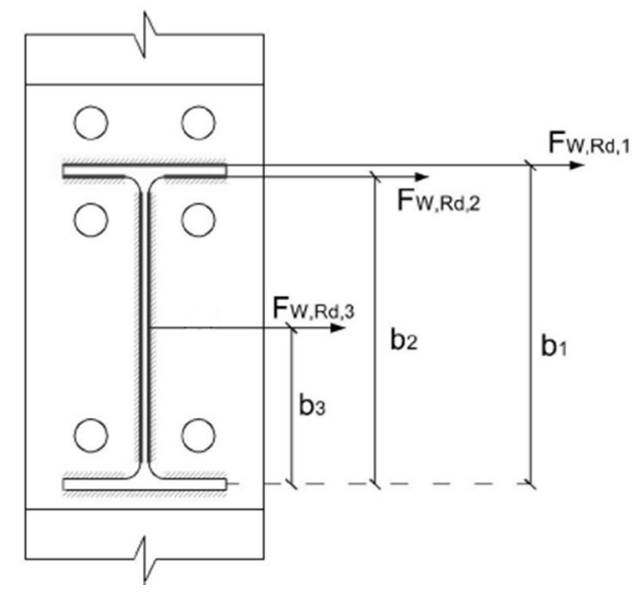

Fonte: Elaborado pela autora.

- Cálculo da resistência da solda por unidade de comprimento, para uma espessura de $6 \mathrm{~mm}$, tem-se a garganta de solda de $4,24 \mathrm{~mm}$ : 


$$
F_{w, R}=\frac{f_{u} \cdot a}{\sqrt{3}}=\frac{485 \cdot 4,24}{\sqrt{3}} \cdot 10^{3}=1,19 \cdot 10^{3} \mathrm{kN} / \mathrm{m}
$$

- O primeiro grupo de solda está situado no limite superior da mesa superior da viga. Assim, o comprimento efetivo do cordão de solda, $1_{\text {eff, }, 1}$ o braço que vai do centro de tração deste grupo ao centro de compressão, b ${ }_{1}$, e a carga concentrada atuante no centro de tração, $\mathrm{F}_{\mathrm{w}, \mathrm{R} 1}$, são dados por:

$$
\begin{gathered}
l_{e f f, 1}=b_{b}=146 \mathrm{~mm} \\
b_{1}=258-\frac{9,1}{2}=253,45 \mathrm{~mm} \\
F_{w, R 1}=1,19 \cdot 10^{3} \cdot 0,146=173,74 \mathrm{kN}
\end{gathered}
$$

- O segundo grupo de solda está situado no limite inferior da mesa superior da viga. Assim, o comprimento efetivo do cordão de solda, $1_{\text {eff }, 2,}$ o braço que vai do centro de tração deste grupo ao centro de compressão, b2, e a carga concentrada atuante no centro de tração, $\mathrm{F}_{\mathrm{w}, \mathrm{R} 2}$, são dados por:

$$
\begin{gathered}
l_{\text {eff }, 2}=146-20-6,1=119,9 \mathrm{~mm} \\
b_{2}=258-\frac{3 \cdot 9,1}{2}=244,35 \mathrm{~mm} \\
F_{w, R 2}=1,19 \cdot 10^{3} \cdot 0,1199=142,68 \mathrm{kN}
\end{gathered}
$$

- O terceiro grupo de solda corresponde aos cordões de soldas situados em ambos os lados da alma da viga. Naturalmente, o centro de tensões deste grupo situa-se à meia altura da viga. Logo:

$$
\begin{gathered}
l_{e f f, 3}=2 \cdot(258-20-2 \cdot 9,1)=439,6 \mathrm{~mm} \\
b_{3}=\frac{258}{2}-\frac{9,1}{2}=124,45 \mathrm{~mm} \\
F_{w, R 3}=1,19 \cdot 10^{3} \cdot 0,4396=523,12 \mathrm{kN}
\end{gathered}
$$

- Cálculo do momento resistente absorvido pelos cordões de solda:

$$
M_{w, R}=\sum_{r} b_{r} F_{w r}=(253,45 \cdot 173,74+244,35 \cdot 142,68+124,45 \cdot 523,12) 10^{-3}=
$$
144 kN.m 
Como $M_{w, R} \gg M_{j, R}$, considera-se que o momento resistente da ligação é igual a $\mathrm{M}_{\mathrm{j}, \mathrm{R}}$ de $32,23 \mathrm{kN}$.m, e para um braço de alavanca de 1,5, a força última é igual a $21,5 \mathrm{kN}$. Concluiu-se que a análise teórica apontou que as barras estavam com folga, como observado no resultado experimental, no qual o ponto crítico era a mesa do pilar.

\section{A.2) Tipologia 4}

Uma vez definidas as características do modelo físico, foi feita a análise teórica do mesmo, utilizando-se as expressões teóricas mostradas no Capítulo 3 do EC3 (2005), a fim de se obter uma previsão teórica da capacidade resistente da ligação. A seguir, é apresentada uma previsão teórica da Tipologia 4 com a ligação no eixo de maior momento de inércia do pilar misto e sem interrupção do concreto na ligação. Como a ligação foi feita com chapa de topo e barras passantes, não foi verificado o perfil de aço do pilar misto à tração e à flexão.

\section{a) Descrição dos Elementos de Ligação}

O pilar tem $87,10 \mathrm{~cm}$ de comprimento desde a ligação estudada até ao solo e estende-se até $91,25 \mathrm{~cm}$ para cima da ligação considerada. A viga tem 1,5 $\mathrm{m}$ de comprimento e o perfil possui as características indicadas na Figura 4.1b. A chapa de extremidade tem 334 x 152 x 16 $\mathrm{mm}$ dimensões e as barras passantes têm diâmetro de $15 \mathrm{~mm}$, encontrando-se as suas propriedades na Tabela 4.3. Visto que as forças de compressão atuantes em ambos os perfís são muito reduzidas, admitiu-se que para o efeito de classificação dos perfis encontram-se ambos em flexão simples. Assim considera-se que tanto a viga como o pilar são de classe 1, ou seja, admite-se uma distribuição de tensões em regime plástico.

\section{b) Identificação das Componentes}

Tendo o momento atuante na ligação sentido negativo, é natural que as componentes localizadas junto à mesa inferior da viga se encontrem em compressão e as restantes à tração. Assim, são identificadas as seguintes componentes que influenciam o valor do momento resistente da ligação na Tabela A.6.

Tabela A.6 - Identificação das componentes ativas em cada linha de compressão ou tração.

\begin{tabular}{|c|c|}
\hline \multicolumn{2}{|c|}{ Componentes } \\
\hline 1 & Alma do pilar ao cisalhamento \\
\hline 2 & Alma do pilar em compressão transversal \\
\hline 5 & Chapa de extremidade à flexão \\
\hline
\end{tabular}


Fonte: Elaborado pela autora.

\begin{tabular}{|c|c|}
\hline 7 & Mesa e alma da viga em compressão \\
\hline 8 & Alma da viga em tração \\
\hline 10 & Parafusos à tração \\
\hline 19 & Soldas à tração \\
\hline Linha & Componentes Ativas \\
\hline 1 & 5,10 e 19 \\
\hline 2 & $5,8,10$ e 19 \\
\hline Compressão & 1,2 e 7 \\
\hline
\end{tabular}

\section{c) Considerações Iniciais de Dimensionamento}

Para calcular o momento resistente da ligação e a sua rigidez rotacional, consideraramse as seguintes hipóteses:

- O centro de compressão encontra-se a meio da espessura da mesa inferior da viga;

- O centro de tração é considerado inicialmente como localizado a meio da espessura da mesa superior da viga. Após o cálculo da rigidez de todas as componentes, é estimada a sua localização mais exata.

d) Cálculo do Valor Resistente das Componentes - Linha de Compressão

Componente 1 - Alma do pilar sujeita ao cisalhamento:

- Verificação da condição de limite da esbelteza da alma do pilar:

$$
\begin{gathered}
\varepsilon=\sqrt{\frac{235}{380}}=0,79 \\
\frac{d_{c}}{t_{w c}}=\frac{119}{5,8}=20,51 \\
20,51 \leq 69 \cdot 0,79=54,51(\mathrm{ok})
\end{gathered}
$$

- Verificada esta condição, considera-se aplicável o método já descrito. O cálculo da área resistente ao cisalhamento do pilar:

$$
A_{v c}=29-2 \cdot 15,2 \cdot 0,66+(0,58+2 \cdot 1) \cdot 0,66=10,64 \mathrm{~cm}^{2}
$$


- Devido ao concreto de revestimento considerado na ligação, a área Avc tem de ser aumentada pela área de reforço, sugere-se uma substituição da área de concreto por uma área de aço correspondente:

$$
A_{v c}=10,64+\frac{35000 \cdot(13,9 \cdot 14,6)}{200000}=46,15 \mathrm{~cm}^{2}
$$

- Resistência da alma do pilar ao cisalhamento:

$$
\begin{gathered}
V_{w p, R}=\frac{0,9 \cdot 380 \cdot 46,15 \cdot 10^{-1}}{\sqrt{3}}=911,25 \mathrm{kN} \\
k_{1}=\infty(\beta=0)
\end{gathered}
$$

Componente 2 - Alma do pilar sujeita à compressão:

- Levando em conta que o presente estudo é de ligação com chapa de topo e barras passantes, o comprimento efetivo da alma do pilar em compressão transversal é calculado através da seguinte expressão:

$b_{e f f, c, w c}=9,1+2 \sqrt{2} \cdot 6+5 \cdot(6,6+10)+16=125,07 \mathrm{~mm}$

- É necessário verificar qual o valor de $s_{p}$ a ser utilizado. Este valor depende da relação entre a espessura da chapa de topo, $t_{p}$, e a extensão desta para além da mesa inferior da viga que é igual a $11 \mathrm{~mm}$.

$$
t_{p}=16 \geq 11 \mathrm{~mm}, \text { então } s_{p}=t_{p}=16 \mathrm{~mm}
$$

- Observando a Tabela 3.3 conclui-se que:

$$
\beta=0 \rightarrow \omega=1
$$

- Cálculo do coeficiente de redução, $\rho$ :

$$
\begin{gathered}
\bar{\lambda}_{p}=0,932 \sqrt{\frac{125,07 \cdot 119 \cdot 380}{200000 \cdot 5,8^{2}}}=0,855 \\
\bar{\lambda}_{p}>0,72 \rightarrow \rho=\frac{\bar{\lambda}_{p}-0,2}{\bar{\lambda}_{p}{ }^{2}}=\frac{0,855-0,2}{0,855^{2}}=0,896 \\
k_{w c}=1
\end{gathered}
$$

- Cálculo da resistência da alma do pilar à compressão transversal: 


$$
\begin{gathered}
F_{c, w c, R}=1 \cdot 1 \cdot 0,896 \cdot 125,07 \cdot 5,8 \cdot 380 \cdot 10^{-3}=246,99 \mathrm{kN} \\
k_{2}=\frac{0,7 \cdot 125,07 \cdot 5,8}{119}=4,27
\end{gathered}
$$

- Como cálculo da resistência do reforço transversal à compressão, Npl,st,Rd, sugere-se a substituição da área comprimida de concreto (linha neutra na metade da altura da viga) por uma área de aço equivalente:

$$
\begin{gathered}
N_{p l, s t, R}=\frac{35000 \cdot(146,2 \cdot 129) \cdot 380 \cdot 10^{-3}}{200000}=1254,18 \mathrm{kN} \\
F_{c, w c, R}+N_{p l, s t, R}=246,99+1254,18=1501,2 \mathrm{kN}
\end{gathered}
$$

Componente 7 - Mesa e alma da viga em compressão:

$$
\begin{gathered}
M_{R}=429 \cdot 380 \cdot 10^{-3}=163,02 \mathrm{kN} \\
F_{c, f b, R}=\frac{163,02}{(258-9,1) \cdot 10^{-3}}=654,96 \mathrm{kN} \\
k_{7}=\infty
\end{gathered}
$$

e) $1^{a}$ Linha de Parafusos Tracionados

- Como se trata de uma linha de extremidade, a sua resistência é considerada como a resistência da linha de parafusos atuando isoladamente.

Componente 5 - Chapa de extremidade à flexão:

- Definição dos parâmetros geométricos:

$$
\begin{gathered}
e=31 \mathrm{~mm} \\
w=90 \mathrm{~mm} \\
e_{x}=31,5 \mathrm{~mm} \\
m_{x}=33,5-0,8 \sqrt{2} \cdot 6=26,71 \mathrm{~mm} \\
b_{p}=152 \mathrm{~mm} \\
m=\frac{90-6,1}{2}-0,8 \sqrt{2} \cdot 6=35,16 \mathrm{~mm}
\end{gathered}
$$


- A $1^{\text {a }}$ linha de parafusos classifica-se como "Linha de parafusos na parte saliente da mesa tracionada da viga". Assim, o comprimento efetivo da chapa de extremidade à flexão para a $1^{\mathrm{a}}$ linha de parafusos é obtido pela Tabela A.7:

Tabela A.7 - Comprimento efetivo da chapa de topo à flexão para a $1^{\mathrm{a}}$ linha de parafusos isolada (ligação não reforçada).

\begin{tabular}{|c|c|c|}
\hline & Configuração Circular & Configuração não Circular \\
\hline $\begin{array}{c}\text { Extensão da chapa de } \\
\text { topo }\end{array}$ & $\begin{array}{c}\text { Menor valor: } \\
2 \pi m_{x}=2 \pi \cdot 26,71=167,82 \\
\pi m_{x}+w=\pi \cdot 26,71+ \\
90=173,91 \\
\pi m_{x}+2 e=\pi \cdot 26,71+ \\
2 \cdot 31=145,91\end{array}$ & $\begin{array}{c}\text { Menor valor: } \\
4 m_{x}+1,25 e_{x}=4 \cdot 26,71+ \\
1,25 \cdot 31,5=146,22 \\
2 m_{x}+0,625 e_{x}+e= \\
2 \cdot 26,71+0,625 \cdot 31,5+31= \\
104,10 \\
2 m_{x}+0,625 e_{x}+ \\
0,5 w=2 \cdot 26,71+0,625 \\
31,5+45=118,10 \\
0,5 b_{p}=0,5 \cdot 152=76\end{array}$ \\
\hline Modo 1 & \multicolumn{2}{|c|}{$l_{e f f, 1}=76 \leq 145,91$} \\
\hline Modo 2 & \multicolumn{2}{|c|}{$l_{e f f, 2}=76$} \\
\hline
\end{tabular}

Fonte: Elaborado pela autora.

- Resistência individual de cada parafuso à tração:

$$
F_{t, R}=0,9 \cdot 1170 \cdot 176,71 \cdot 10^{-3}=186,08 \mathrm{kN}
$$

- Verificação da existência de forças de alavanca:

$$
\begin{gathered}
l_{b}=16+20+\frac{40}{2}=56 \mathrm{~mm} \\
l_{b}^{*}=\frac{8,8 m^{3} A_{s} n_{b}}{\sum l_{e f f, 1} t_{f}^{3}}=\frac{8,8 \cdot 26,71^{3} \cdot 176,71 \cdot 1}{76 \cdot 16^{3}}=95,19 \mathrm{~mm}
\end{gathered}
$$

Como $l_{\mathrm{b}}<\mathrm{l}_{\mathrm{b}}{ }^{*}$, verifica-se a existência de forças de alavanca.

- Cálculo da resistência da chapa de extremidade à flexão transversal:

$$
M_{p l, 1, R}=M_{p l, 2, R}=0,25 \cdot 76 \cdot 16^{2} \cdot 345 \cdot 10^{-6}=1,68 \mathrm{kN} . \mathrm{m}
$$

- Nota-se que na linha de parafusos da extensão da chapa de topo, considera-se que o valor de $\mathrm{m}$ do $\mathrm{T}$-stub equivalente é igual a $\mathrm{m}_{\mathrm{x}}$. 


$$
\begin{gathered}
n \leq e_{\text {min }} \text { e } 1,25 m_{x} \rightarrow n=31 \mathrm{~mm} \\
F_{t, 1, R}=\frac{4 M_{p l, 1, R}}{m_{x}}=\frac{4 \cdot 1,68}{26,71 \cdot 10^{-3}}=251,59 \mathrm{kN} \\
F_{t, 2, R}=\frac{2 M_{p l, 2, R}+n \sum F_{t, R}}{m_{x}+n}=\frac{2 \cdot 1,68+31 \cdot 2 \cdot 186,06 \cdot 10^{-3}}{(26,71+31) \cdot 10^{-3}}=258,11 \mathrm{kN} \\
F_{t, 3, R}=\sum F_{t, R}=2 \cdot 186,06=372,12 \mathrm{kN} \\
k_{5}=\frac{0,9 \cdot 76 \cdot 16^{3}}{26,71^{3}}=14,7
\end{gathered}
$$

- Levando em conta todas as componentes da $1^{\text {a }}$ linha de tração analisadas conclui-se que a resistência desta linha é dada por:

$$
P_{r 1}=251,59 \mathrm{kN}
$$

\section{f) $2^{a}$ Linha de Parafusos Tracionados}

- Para as componentes 5 e 7 considera-se apenas a linha de parafusos isolada, pois a mesa da viga funciona como um divisor de grupos de linhas de tração.

Componente 5 - Chapa de extremidade à flexão:

A $2^{\text {a }}$ linha de parafusos é adjacente à mesa tracionada da viga. Logo, para determinar o comprimento efetivo, é necessário determinar o coeficiente retirado do ábaco.

$$
\begin{gathered}
m_{2}=33,5-0,8 \sqrt{2} \cdot 6=26,71 \\
\lambda_{1}=\frac{35,16}{35,16+31}=0,53 \\
\lambda_{2}=\frac{26,71}{35,16+31}=0,40 \\
\alpha \cong 6
\end{gathered}
$$

- Assim obtêm-se os valores de comprimentos efetivos na Tabela A.8: 
Tabela A.8 - Comprimento efetivo da chapa de extremidade à flexão para a $2^{\mathrm{a}}$ linha de parafusos isolada (ligação não reforçada).

\begin{tabular}{|c|c|c|}
\hline & Configuração Circular & Configuração não Circular \\
\hline Linha isolada & $2 \pi m=2 \pi \cdot 35,16=220,92$ & $\alpha m=6 \cdot 35,16=210,96$ \\
\hline Modo 1 & $l_{e f f, 1}=210,96 \leq 220,92$ \\
\hline Modo 2 & \multicolumn{2}{|c|}{$l_{e f f, 2}=210,96$} \\
\hline
\end{tabular}

Fonte: Elaborado pela autora.

- Cálculo da resistência da chapa de extremidade à flexão transversal:

$$
\begin{gathered}
M_{p l, 1, R}=M_{p l, 2, R}=0,25 \cdot 210,96 \cdot 16^{2} \cdot 345 \cdot 10^{-6}=4,66 \mathrm{kN} . \mathrm{m} \\
F_{t, 1, R}=\frac{4 M_{p l, 1, R}}{m}=\frac{4 \cdot 4,66}{35,16 \cdot 10^{-3}}=530,15 \mathrm{kN} \\
F_{t, 2, R}=\frac{2 M_{p l, 2, R}+n \sum F_{t, R}}{m+n}=\frac{2 \cdot 4,66+31 \cdot 2 \cdot 186,06 \cdot 10^{-3}}{(35,16+31) \cdot 10^{-3}}=315,23 \mathrm{kN} \\
F_{t, 3, R}=\sum F_{t, R}=2 \cdot 186,06=372,12 \mathrm{kN} \\
k_{5}=\frac{0,9 \cdot 210,96 \cdot 16^{3}}{35,16^{3}}=17,9
\end{gathered}
$$

Conclui-se que o modo de ruptura é o segundo.

Componente 8 - Alma da viga em tração:

- De forma análoga à alma do pilar em tração transversal, a largura efetiva desta componente é igual ao comprimento efetivo do $1^{\circ}$ modo de ruptura da chapa de topo à flexão.

$$
b_{\text {eff }, t, w b}=l_{\text {eff }, 1}=210,96
$$

- Assim a resistência desta componente é dada por:

$$
F_{t, w b, R}=210,96 \cdot 6,1 \cdot 380 \cdot 10^{-3}=489 \mathrm{kN}
$$

- Resistência da $2^{\mathrm{a}}$ linha de tração:

$$
P_{r 2}=\operatorname{mínimo}\{315,23 ; 489\} \cong 315,23 \mathrm{kN}
$$

A resistência da $2^{\mathrm{a}}$ linha de parafusos é dada pela resistência da chapa à flexão. 


\section{g) Cálculo do Momento Resistente da Ligação}

- O cálculo do momento resistente da ligação é feito de acordo:

$$
M_{j, R}=\sum_{r} h_{r} F_{t r, R}
$$

- Em que a força de tração de cada linha de parafusos, $F_{t r}$, equivale à sua componente menos resistente, $\mathrm{P}_{\mathrm{rn}}$, e o braço, $\mathrm{h}_{\mathrm{r}}$, equivale à distância entre $\mathrm{o}$ centro geométrico dos parafusos e o centro de compressão.

- Entretanto, é necessário relembrar que para se verificar o equilíbrio de forças, o somatório das forças de tração não pode ultrapassar a força de compressão máxima, que neste caso é equivalente à resistência da mesa e alva da viga em compressão.

$$
\sum_{r} F_{t r}=F_{c r}=F_{c, f b, R}=654,96 \mathrm{kN}
$$

- Assim, verifica-se, linha a linha, se o somatório das forças de tração ultrapassa ou não o valor de resistência da ligação à compressão.

$$
1^{\mathrm{a}} \text { Linha: } 251,59 \mathrm{kN}<654,96 \mathrm{kN} \text { (ok) }
$$

- Nestas condições, a resistência da $1^{\text {a }}$ linha de parafusos à tração é aproveitada na sua totalidade.

$$
2^{\mathrm{a}} \text { Linha: } 251,59+315,23=566,82 \mathrm{kN}<654,96 \mathrm{kN}
$$

- Nestas condições, a resistência da $2^{\mathrm{a}}$ linha de parafusos à tração é aproveitada na sua totalidade.

- Finalmente, o momento resistente da ligação é dado por:

$M_{j, R}=h_{1} F_{t 1, R}+h_{2} F_{t 2, R}=(286,95 \cdot 251,59+211,95 \cdot 315,23) \cdot 10^{-3}=139 \mathrm{kN} . \mathrm{m}$

\section{h) Momento Resistente da Solda}

Adotando um método simplificado, admite-se que a solda que resiste às forças de tração provocadas por um momento atuante negativo são as soldas que ligam a mesa superior e a alma da viga à chapa de topo. Assim, para este caso, considera-se que os cordões de solda resistentes às forças de tração estão divididos em três grupos, cada um caracterizado por um centro de tração diferente e consequentemente um braço do binário diferente até ao centro de compressão da ligação (Figura A.1). 
- Cálculo da resistência da solda por unidade de comprimento, para uma espessura de $6 \mathrm{~mm}$, tem-se a garganta de solda de $4,24 \mathrm{~mm}$ :

$$
F_{w, R}=\frac{f_{u} \cdot a}{\sqrt{3}}=\frac{485 \cdot 4,24}{\sqrt{3}} \cdot 10^{3}=1,19 \cdot 10^{3} \mathrm{kN} / \mathrm{m}
$$

- O primeiro grupo de solda está situado no limite superior da mesa superior da viga. Assim, o comprimento efetivo do cordão de solda, $1_{\text {eff, }, 1}$, o braço que vai do centro de tração deste grupo ao centro de compressão, $\mathrm{b}_{1}$, e a carga concentrada atuante no centro de tração, $\mathrm{F}_{\mathrm{w}, \mathrm{R} 1}$, são dados por:

$$
\begin{gathered}
l_{\text {eff }, 1}=b_{b}=146 \mathrm{~mm} \\
b_{1}=258-\frac{9,1}{2}=253,45 \mathrm{~mm} \\
F_{w, R 1}=1,19 \cdot 10^{3} \cdot 0,146=173,74 \mathrm{kN}
\end{gathered}
$$

- O segundo grupo de solda está situado no limite inferior da mesa superior da viga. Assim, o comprimento efetivo do cordão de solda, $1_{\text {eff, }, 2}$ o braço que vai do centro de tração deste grupo ao centro de compressão, b2, e a carga concentrada atuante no centro de tração, $\mathrm{F}_{\mathrm{w}, \mathrm{R} 2}$, são dados por:

$$
\begin{gathered}
l_{\text {eff }, 2}=146-20-6,1=119,9 \mathrm{~mm} \\
b_{2}=258-\frac{3 \cdot 9,1}{2}=244,35 \mathrm{~mm} \\
F_{w, R 2}=1,19 \cdot 10^{3} \cdot 0,1199=142,68 \mathrm{kN}
\end{gathered}
$$

- O terceiro grupo de solda corresponde aos cordões de soldas situados em ambos os lados da alma da viga. Naturalmente, o centro de tensões deste grupo situa-se à meia altura da viga. Logo:

$$
\begin{gathered}
l_{e f f, 3}=2 \cdot(258-20-2 \cdot 9,1)=439,6 \mathrm{~mm} \\
b_{3}=\frac{258}{2}-\frac{9,1}{2}=124,45 \mathrm{~mm} \\
F_{w, R 3}=1,19 \cdot 10^{3} \cdot 0,4396=523,12 \mathrm{kN}
\end{gathered}
$$

- Cálculo do momento resistente absorvido pelos cordões de solda: 


$$
M_{w, R}=\sum_{r} b_{r} F_{w r}=(253,45 \cdot 173,74+244,35 \cdot 142,68+124,45 \cdot 523,12) 10^{-3}=
$$
144 kN.m

Como $M_{w, R}>M_{j, R}$, considera-se que o momento resistente da ligação é igual a $\mathrm{M}_{\mathrm{j}, \mathrm{R}}$ de 139 kN.m, e para um braço de alavanca de 1,5, a força última é igual a $93 \mathrm{kN}$. Concluiu-se que a análise teórica apontou que as barras passantes e as chapas de topo estavam no início do escoamento, o que foi verificado experimentalmente pelo nível das deformações e visualmente, porém, não se descarta a influência da solda, na qual seu momento resistente estava próximo do momento resistente da ligação. Além disso, na previsão teórica, foi considerada a resistência ao escoamento dos perfis de aço dos modelos pilotos, mas se obteve uma pequena divergência em comparação aos modelos definitivos.

\section{A.3) Tipologia 5}

A seguir, é apresentada uma previsão teórica da Tipologia 5 com a ligação no eixo de menor momento de inércia do pilar misto e sem interrupção do concreto na ligação. Como a ligação foi feita com chapa de topo e barras passantes no eixo de menor inércia, não foi verificado o perfil de aço do pilar misto.

\section{a) Descrição dos Elementos de Ligação}

O pilar tem $87,10 \mathrm{~cm}$ de comprimento desde a ligação estudada até ao solo e estende-se até $91,25 \mathrm{~cm}$ para cima da ligação considerada. A viga tem 1,5 $\mathrm{m}$ de comprimento e o perfil possui as características indicadas na Figura 4.1b. A chapa de extremidade tem 334 x 152 x 16 $\mathrm{mm}$ dimensões e as barras passantes têm diâmetro de $15 \mathrm{~mm}$, encontrando-se as suas propriedades na Tabela 4.3. Visto que as forças de compressão atuantes em ambos os perfis são muito reduzidas, admitiu-se que para o efeito de classificação dos perfis encontram-se ambos em flexão simples. Assim considera-se que tanto a viga como o pilar são de classe 1, ou seja, admite-se uma distribuição de tensões em regime plástico.

\section{b) Identificação das Componentes}

Tendo o momento atuante na ligação sentido negativo, é natural que as componentes localizadas junto à mesa inferior da viga se encontrem em compressão e as restantes à tração. Assim, são identificadas as seguintes componentes que influenciam o valor do momento 
resistente da ligação na Tabela A.9. Como a ligação era no eixo de menor inércia do pilar misto, não se demonstrou a verificação da mesa do pilar ao cisalhamento e em compressão transversal.

Tabela A.9 - Identificação das componentes ativas em cada linha de compressão ou tração.

Fonte: Elaborado pela autora.

\begin{tabular}{|c|c|}
\hline \multicolumn{2}{|c|}{ Componentes } \\
\hline 1 & Mesa do pilar ao cisalhamento \\
\hline 2 & Mesa do pilar em compressão transversal \\
\hline 5 & Chapa de extremidade à flexão \\
\hline 7 & Mesa e alma da viga em compressão \\
\hline 8 & Alma da viga em tração \\
\hline 10 & Parafusos à tração \\
\hline 19 & Soldas à tração \\
\hline Linha & Componentes Ativas \\
\hline 1 & 5,10 e 19 \\
\hline 2 & $5,8,10$ e 19 \\
\hline Compressão & 1,2 e 7 \\
\hline
\end{tabular}

\section{c) Considerações Iniciais de Dimensionamento}

Para calcular o momento resistente da ligação e a sua rigidez rotacional, consideraramse as seguintes hipóteses:

- O centro de compressão encontra-se a meio da espessura da mesa inferior da viga;

- O centro de tração é considerado inicialmente como localizado a meio da espessura da mesa superior da viga. Após o cálculo da rigidez de todas as componentes, é estimada a sua localização mais exata.

d) Cálculo do Valor Resistente das Componentes - Linha de Compressão

Componente 7 - Mesa e alma da viga em compressão:

$$
\begin{gathered}
M_{R}=429 \cdot 380 \cdot 10^{-3}=163,02 \mathrm{kN} \\
F_{c, f b, R}=\frac{163,02}{(258-9,1) \cdot 10^{-3}}=654,96 \mathrm{kN} \\
k_{7}=\infty
\end{gathered}
$$

e) $1^{a}$ Linha de Parafusos Tracionados 
- Como se trata de uma linha de extremidade, a sua resistência é considerada como a resistência da linha de parafusos atuando isoladamente.

Componente 5 - Chapa de extremidade à flexão:

- Definição dos parâmetros geométricos:

$$
\begin{gathered}
e=31 \mathrm{~mm} \\
w=90 \mathrm{~mm} \\
e_{x}=31,5 \mathrm{~mm} \\
m_{x}=33,5-0,8 \sqrt{2} \cdot 6=26,71 \mathrm{~mm} \\
b_{p}=152 \mathrm{~mm} \\
m=\frac{90-6,1}{2}-0,8 \sqrt{2} \cdot 6=35,16 \mathrm{~mm}
\end{gathered}
$$

\begin{tabular}{|c|c|c|}
\hline & Configuração Circular & Configuração não Circular \\
\hline $\begin{array}{c}\text { Extensão da chapa de } \\
\text { topo }\end{array}$ & $\begin{array}{c}\text { Menor valor: } \\
2 \pi m_{x}=2 \pi \cdot 26,71=167,82 \\
\pi m_{x}+w=\pi \cdot 26,71+ \\
90=173,91 \\
\pi m_{x}+2 e=\pi \cdot 26,71+ \\
2 \cdot 31=145,91\end{array}$ & $\begin{array}{c}\text { Menor valor: } \\
4 m_{x}+1,25 e_{x}=4 \cdot 26,71+ \\
1,25 \cdot 31,5=146,22 \\
2 m_{x}+0,625 e_{x}+e= \\
2 \cdot 26,71+0,625 \cdot 31,5+31= \\
104,10 \\
2 m_{x}+0,625 e_{x}+ \\
0,5 w=2 \cdot 26,71+0,625 \\
31,5+45=118,10 \\
0,5 b_{p}=0,5 \cdot 152=76\end{array}$ \\
\hline Modo 1 & \multicolumn{2}{|c|}{$l_{e f f, 1}=76 \leq 145,91$} \\
\hline Modo 2 & \multicolumn{2}{|c|}{$l_{e f f, 2}=76$} \\
\hline
\end{tabular}

- A $1^{\text {a }}$ linha de parafusos classifica-se como "Linha de parafusos na parte saliente da mesa tracionada da viga". Assim, o comprimento efetivo da chapa de extremidade à flexão para a $1^{\mathrm{a}}$ linha de parafusos é obtido pela Tabela A.7:

Tabela A.7 - Comprimento efetivo da chapa de topo à flexão para a $1^{\mathrm{a}}$ linha de parafusos isolada (ligação não reforçada).

Fonte: Elaborado pela autora.

- Resistência individual de cada parafuso à tração: 


$$
F_{t, R}=0,9 \cdot 1170 \cdot 176,71 \cdot 10^{-3}=186,08 \mathrm{kN}
$$

- Verificação da existência de forças de alavanca:

$$
\begin{gathered}
l_{b}=22,2+20+\frac{40}{2}=62,2 \mathrm{~mm} \\
l_{b}^{*}=\frac{8,8 m^{3} A_{s} n_{b}}{\sum l_{e f f, 1} t_{f}^{3}}=\frac{8,8 \cdot 26,71^{3} \cdot 176,71 \cdot 1}{76 \cdot 22,2^{3}}=35,64 \mathrm{~mm}
\end{gathered}
$$

Como $l_{b}>l_{b}{ }^{*}$, verifica-se a não existência de forças de alavanca.

- Cálculo da resistência da chapa de extremidade à flexão transversal:

$$
M_{p l, 1, R}=M_{p l, 2, R}=0,25 \cdot 76 \cdot 22,2^{2} \cdot 345 \cdot 10^{-6}=3,23 \mathrm{kN} . \mathrm{m}
$$

- Nota-se que na linha de parafusos da extensão da chapa de topo, considera-se que o valor de $\mathrm{m}$ do $\mathrm{T}$-stub equivalente é igual a $\mathrm{m}_{\mathrm{x}}$.

$$
\begin{gathered}
n \leq e_{\text {min }} \text { e } 1,25 m_{x} \rightarrow n=31 \mathrm{~mm} \\
F_{t, 1-2, R}=\frac{2 M_{p l, 1, R}}{m_{x}}=\frac{2 \cdot 3,23}{26,71 \cdot 10^{-3}}=241,86 \mathrm{kN} \\
F_{t, 3, R}=\sum F_{t, R}=2 \cdot 186,06=372,12 \mathrm{kN} \\
k_{5}=\frac{0,9 \cdot 76 \cdot 22,2^{3}}{26,71^{3}}=39,3
\end{gathered}
$$

- Levando em conta todas as componentes da $1^{\mathrm{a}}$ linha de tração analisadas conclui-se que a resistência desta linha é dada por:

$$
P_{r 1}=241,86 \mathrm{kN}
$$

\section{f) $2^{a}$ Linha de Parafusos Tracionados}

- Para as componentes 5 e 7 considera-se apenas a linha de parafusos isolada, pois a mesa da viga funciona como um divisor de grupos de linhas de tração.

Componente 5 - Chapa de extremidade à flexão:

A $2^{\mathrm{a}}$ linha de parafusos é adjacente à mesa tracionada da viga. Logo, para determinar o comprimento efetivo, é necessário determinar o coeficiente retirado do ábaco. 


$$
\begin{gathered}
m_{2}=33,5-0,8 \sqrt{2} \cdot 6=26,71 \\
\lambda_{1}=\frac{35,16}{35,16+31}=0,53 \\
\lambda_{2}=\frac{26,71}{35,16+31}=0,40 \\
\alpha \cong 6
\end{gathered}
$$

- Assim obtêm-se os valores de comprimentos efetivos na Tabela A.8:

Tabela A.8 - Comprimento efetivo da chapa de extremidade à flexão para a $2^{\mathrm{a}}$ linha de parafusos isolada (ligação não reforçada).

\begin{tabular}{|c|c|c|}
\hline & Configuração Circular & Configuração não Circular \\
\hline Linha isolada & $2 \pi m=2 \pi \cdot 35,16=220,92$ & $\alpha m=6 \cdot 35,16=210,96$ \\
\hline Modo 1 & $l_{e f f, 1}=210,96 \leq 220,92$ \\
\hline Modo 2 & \multicolumn{2}{|c|}{$l_{e f f, 2}=210,96$} \\
\hline
\end{tabular}

Fonte: Elaborado pela autora.

- Cálculo da resistência da chapa de extremidade à flexão transversal:

$$
\begin{gathered}
M_{p l, 1, R}=M_{p l, 2, R}=0,25 \cdot 210,96 \cdot 22,2^{2} \cdot 345 \cdot 10^{-6}=8,97 \mathrm{kN} . \mathrm{m} \\
F_{t, 1-2, R}=\frac{2 M_{p l, 1, R}}{m}=\frac{2 \cdot 8,97}{35,16 \cdot 10^{-3}}=510,24 \mathrm{kN} \\
F_{t, 3, R}=\sum F_{t, R}=2 \cdot 186,06=372,12 \mathrm{kN} \\
k_{5}=\frac{0,9 \cdot 210,96 \cdot 22,2^{3}}{35,16^{3}}=47,8
\end{gathered}
$$

Conclui-se que o modo de ruptura é o terceiro.

Componente 8 - Alma da viga em tração:

- De forma análoga à alma do pilar em tração transversal, a largura efetiva desta componente é igual ao comprimento efetivo do $1^{\mathrm{o}}$ modo de ruptura da chapa de topo à flexão.

$$
b_{e f f, t, w b}=l_{e f f, 1}=210,96
$$

- Assim a resistência desta componente é dada por: 


$$
F_{t, w b, R}=210,96 \cdot 6,1 \cdot 380 \cdot 10^{-3}=489 \mathrm{kN}
$$

- Resistência da $2^{\mathrm{a}}$ linha de tração:

$$
P_{r 2}=\operatorname{mínimo}\{372,12 ; 489\} \cong 372,12 \mathrm{kN}
$$

g) Cálculo do Momento Resistente da Ligação

- O cálculo do momento resistente da ligação é feito de acordo:

$$
M_{j, R}=\sum_{r} h_{r} F_{t r, R}
$$

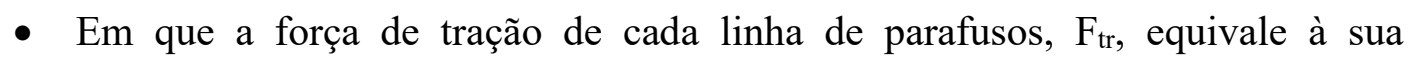
componente menos resistente, $\mathrm{P}_{\mathrm{rn}}$, e o braço, $\mathrm{h}_{\mathrm{r}}$, equivale à distância entre $\mathrm{o}$ centro geométrico dos parafusos e o centro de compressão.

- Entretanto, é necessário relembrar que para se verificar o equilíbrio de forças, o somatório das forças de tração não pode ultrapassar a força de compressão máxima, que neste caso é equivalente à resistência da mesa e alva da viga em compressão.

$$
\sum_{r} F_{t r}=F_{c r}=F_{c, f b, R}=654,96 \mathrm{kN}
$$

- Assim, verifica-se, linha a linha, se o somatório das forças de tração ultrapassa ou não o valor de resistência da ligação à compressão.

$$
1^{\text {a }} \text { Linha: } 241,86 \mathrm{kN}<654,96 \mathrm{kN} \text { (ok) }
$$

- Nestas condições, a resistência da $1^{a}$ linha de parafusos à tração é aproveitada na sua totalidade.

$$
2^{\mathrm{a}} \text { Linha: } 241,86+372,12=613,98 \mathrm{kN}<654,96 \mathrm{kN}
$$

- Nestas condições, a resistência da $2^{\mathrm{a}}$ linha de parafusos à tração é aproveitada na sua totalidade.

- Finalmente, o momento resistente da ligação é dado por:

$$
M_{j, R}=h_{1} F_{t 1, R}+h_{2} F_{t 2, R}=(286,95 \cdot 241,86+211,95 \cdot 372,12) \cdot 10^{-3}=148 \mathrm{kN} . \mathrm{m}
$$

\section{h) Momento Resistente da Solda}

Adotando um método simplificado, admite-se que a solda que resiste às forças de tração provocadas por um momento atuante negativo são as soldas que ligam a mesa superior e a alma 
da viga à chapa de topo. Assim, para este caso, considera-se que os cordões de solda resistentes às forças de tração estão divididos em três grupos, cada um caracterizado por um centro de tração diferente e consequentemente um braço do binário diferente até ao centro de compressão da ligação (Figura A.1).

- Cálculo da resistência da solda por unidade de comprimento, para uma espessura de $6 \mathrm{~mm}$, tem-se a garganta de solda de $4,24 \mathrm{~mm}$ :

$$
F_{w, R}=\frac{f_{u} \cdot a}{\sqrt{3}}=\frac{485 \cdot 4,24}{\sqrt{3}} \cdot 10^{3}=1,19 \cdot 10^{3} \mathrm{kN} / \mathrm{m}
$$

- O primeiro grupo de solda está situado no limite superior da mesa superior da viga. Assim, o comprimento efetivo do cordão de solda, leff,1, o braço que vai do centro de tração deste grupo ao centro de compressão, b 1 , e a carga concentrada atuante no centro de tração, $\mathrm{F}_{\mathrm{w}, \mathrm{R} 1}$, são dados por:

$$
\begin{gathered}
l_{\text {eff }, 1}=b_{b}=146 \mathrm{~mm} \\
b_{1}=258-\frac{9,1}{2}=253,45 \mathrm{~mm} \\
F_{w, R 1}=1,19 \cdot 10^{3} \cdot 0,146=173,74 \mathrm{kN}
\end{gathered}
$$

- O segundo grupo de solda está situado no limite inferior da mesa superior da

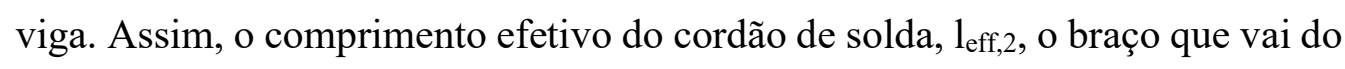
centro de tração deste grupo ao centro de compressão, b2, e a carga concentrada atuante no centro de tração, $\mathrm{F}_{\mathrm{w}, \mathrm{R} 2}$, são dados por:

$$
\begin{gathered}
l_{\text {eff }, 2}=146-20-6,1=119,9 \mathrm{~mm} \\
b_{2}=258-\frac{3 \cdot 9,1}{2}=244,35 \mathrm{~mm} \\
F_{w, R 2}=1,19 \cdot 10^{3} \cdot 0,1199=142,68 \mathrm{kN}
\end{gathered}
$$

- O terceiro grupo de solda corresponde aos cordões de soldas situados em ambos os lados da alma da viga. Naturalmente, o centro de tensões deste grupo situa-se à meia altura da viga. Logo:

$$
l_{\text {eff }, 3}=2 \cdot(258-20-2 \cdot 9,1)=439,6 \mathrm{~mm}
$$




$$
\begin{gathered}
b_{3}=\frac{258}{2}-\frac{9,1}{2}=124,45 \mathrm{~mm} \\
F_{w, R 3}=1,19 \cdot 10^{3} \cdot 0,4396=523,12 \mathrm{kN}
\end{gathered}
$$

- Cálculo do momento resistente absorvido pelos cordões de solda:

$$
M_{w, R}=\sum_{r} b_{r} F_{w r}=(253,45 \cdot 173,74+244,35 \cdot 142,68+124,45 \cdot 523,12) 10^{-3}=
$$

144 kN.m

Como $M_{w, R}<M_{j, R}$, considera-se que o momento resistente da ligação é igual a $\mathrm{M}_{\mathrm{w}, \mathrm{R}}$ de 144 kN.m, e para um braço de alavanca de 1,5, a força última é igual a $96 \mathrm{kN}$. Concluiu-se que a análise teórica apontou que o ponto crítico era a solda, como observado no resultado experimental. 